\title{
AVALIAÇÃO DA PRESENÇA DOS PROTOZOÁRIOS Giardia sp E Cryptosporidium sp EM ÁGUAS SUPERFICIAIS DESTINADAS A CAPTAÇÃO E TRATAMENTO PARA CONSUMO HUMANO NO ESTADO DE SÃO PAULO
}

\author{
ELAYSE MARIA HACHICH
}

Tese de Doutorado apresentada ao Departamento de Saúde Ambiental da Faculdade de Saúde Pública da Universidade de São Paulo para obtenção do Grau de Doutor

Área de Concentração:

Saúde Ambiental

ORIENTADOR : PROF. DR. JOSÉ LUIZ NEGRÃO MUCCI

São Paulo

2002 


\section{AGRADECIMENTOS}

Ao Prof. Dr. JOSÉ LUIZ NEGRÃO MUCCI pela orientação segura, incentivo e apoio para a realização desse trabalho e pela relação de amizade construida durante esses 4 anos do Curso de Pós-Graduação.

Ao Prof. Titular ARISTIDES ALMEIDA ROCHA pelo apoio junto à Comissão de PósGraduação.

À Banca de Qualificação e à Pré-banca, pelas valiosas sugestões que contribuíram de forma expressiva para o aperfeiçoamento desse trabalho

À Biblioteca da Faculdade de Saúde Pública, pelo auxilio na revisão das Referências Bibliográficas, e à funcionária SUELI pelos inúmeros trabalhos obtidos através do Serviço de Comutação Bibliográfica.

Á CETESB, Companhia de Tecnologia de Saneamento Ambiental do Estado de São Paulo, que autorizou a realização desse Curso de Pós-Graduação e a utilização dos dados de seu Projeto "Avaliação da Qualidade das Águas Interiores do Estado de São Paulo".

A todas as funcionárias da Secretaria de Pós-Graduação e do Setor de Aprimoramento pela atenção e gentileza com que sempre fui atendida.

A Dra. PETRA SANCHEZ SANCHEZ pelo estímulo ao meu ingresso na área de Microbiologia Ambiental. 
À Dra. MARIA INÊS ZANOLI SATO, Gerente do Departamento de Análises Ambientais da CETESB pelo apoio à realização desse Curso de Pós-Graduação, pelos valiosos conhecimentos transmitidos através de nosso trabalho em conjunto nos últimos 10 anos na Companhia, e pelo exemplo de dedicação ao Estudo, à Ciência e ao Trabalho que ela demonstrou durante esse tempo.

Ao NELSON MENEGON JÚNIOR, Gerente do Setor de Qualidade de Águas Interiores da CETESB, pelos esclarecimentos e discussões sobre dados referentes à qualidade das águas superficiais estudadas nesse trabalho.

Ao ANTONIO BRUNI, estatístico da CETESB, pela avaliação estatística dos resultados das análises, e leitura crítica da Discussão dos Resultados.

À ANA ROSA COSTA. secretária do Departamento de Qualidade das Águas, pelo fornecimento dos mapas das Unidades de Gerenciamento de Recursos Hídricos.

Aos funcionários do Setor de Microbiologia e Parasitologia da CETESB:

ANA TEREZA GALVANI e JOSÉ ANTONIO PADULA pela realização das análises de Giardia e Cryptosporidium.

ADALGISA MARIA DE JESUS MELO, MARIA CRISTINA L.S. COELHO e MARISA DI BARI pela realização das análises de coliformes fecais, estreptocoos fecais e Clostridium perfringens

DOROTHY O.. MATHEUS, HILDA NASCIMENTO E SILVA, LAVÍNIA DA SILVA, OCTÁVIO LUIZ .FERREIRA. e SEBASTIÃO NONATO pelo preparo dos meios de cultura e materiais utilizados na realização das análises 


\section{INDICE}

1. Introdução 1

1.1. Doenças Infecciosas e Água de Consumo Humano 3

1.1.1. As Gastroenterites causadas pelos Protozoários Giardia e 5 Cryptosporidium

1.1.2. A Ocorrência de Giardíase e Criptosporidiose no Brasil 12

1.1.3. Giardia e Cryptosporidium como Agentes causadores de 15

Gastroenterites de Veiculação Hídrica

1.2. Giardia e Cryptosporidium no Ambiente 24

1.2.1. Efluentes Domésticos 25

1.2.2. Águas Superficiais e Subterrâneas Brutas 30

1.2.3. Águas Tratadas 35

2. Legislação $\quad 37$

2.1. A legislação Americana 37

2.2. A legislação Inglesa 39

2.3. A legislação Brasileira $\quad 40$

2.4. A legislação de Outros Países 41

3. Objetivos 42

4. Materiais e Métodos $\quad 43$

4.1. Amostragem 43

4.1.1. Locais e Periodicidade da Coleta 43

4.1.2. Técnicas de Coleta, Preservação e Transporte das amostras 67

4.2. Análise dos Protozoários Giardia sp e Cryptosporidium sp através da $\quad 67$ Técnica de Concentração por Floculação com Carbonato de Cálcio e Microscopia de Imunofluorescência

4.2.1. Procedimentos para concentração da amostra 68

$\begin{array}{ll}\text { 4.2.2. Reação de Imunofluorescência } & 69\end{array}$ 
4.2.3. Leitura $\quad 69$

4.2.4. Cálculo dos Resultados 70

4.2.5. Controles Negativos $\quad 70$

4.2.6 Determinação da Porcentagem de Recuperação do Método 70

4.3. Análise dos Indicadores Bacterianos de Contaminação Fecal 71

4.3.1. Coliformes Fecais $\quad 71$

4.3.2 Estreptococos Fecais $\quad 72$

4.3.3.Clostridium perfringens $\quad 73$

4.4 Análise estatística dos resultados $\quad 75$

5. Resultados 76

5.1. Resultados Globais das Análises de Giardia sp e Cryptosporidium sp 76

$\begin{array}{ll}\text { 5.2. Controles Negativos } & 78\end{array}$

5.3 Determinação da Porcentagem de Recuperação do Método 78

5.4. Resultados das Análises de Giardia sp e Cryptosporidium sp e das 78

Bactérias Indicadoras de Contaminação Fecal, Coliformes fecais,

Estreptococos fecais e Clostridium perfringens em cada UGRHI

5.4.1. UGRHI 02 - Paraíba do Sul 78

5.4.2. UGRHI 05 - Piracicaba, Capivari, Jundiai 81

5.4.3. UGRHI 06 - Alto Tietê 87

5.4.4. UGRHI 07 - Baixada Santista 97

5.4.5. UGRHI 09 - Mogi-Guaçú 100

5.4.6. UGRHI 10 - Sorocaba/Médio Tietê 101

5.4.7. UGRHI 15 - Turvo Grande 103

5.4.8. UGRHI 17 - Médio Paranapanema 105

$\begin{array}{ll}\text { 5.4.9.UGRHI } 21 \text { - Peixe } & 106\end{array}$

$\begin{array}{ll}\text { 5.4.10. UGRHI } 22 \text { - Pontal do Paranapanema } & 108\end{array}$ 
5.5. Resultados da Correlação de Postos de Spearman entre as 110 Concentrações de Giardia sp e as Bactérias Indicadoras de Contaminação Fecal, Coliformes fecais, Estreptococos fecais e $C$. perfingens

5.5.1. Correlação de Postos de Spearman para a Totalidade das Amostras Analisadas

5.5.2. Correlação de Postos de Spearman em cada UGRHI

6. Discussão dos Resultados

6.1. Resultados Globais das Análises de Giardia sp e Cryptosporidium sp

6.2. Resultados das Análises de Giardia sp e Cryptosporidium sp em cada UGRHI

6.2.1. UGRHI 02 - Paraiba do Sul

6.2.2. UGRHI 05 - Piracicaba, Capivari, Jundiaí

6.2.3. UGRHI 06 - Alto Tietê

6.2.5. UGRHI 09 - Mogi-Guaç

6.2.6. UGRHI 10 - Sorocaba/Médio Tietê

6.2.8. UGRHI 17 - Médio Paranapanema

6.3. Relação entre as Concentrações dos Protozoários e dos Indicadores de Contaminação Fecal

6.3.1. . Utilização do coeficiente de postos de Spearman para estudo da correlação entre parâmetros microbiológicos de qualidade da água

6.3.2 Relação entre as Concentrações de Cryptosporidium sp e os Indicadores de Contaminação Fecal 
6.3.3 Relação entre as Concentrações de Cryptosporidium sp e dos Indicadores de Contaminação fecal

6.3.4 Relação entre as Concentrações de Giardia sp e dos Indicadores de Contaminação fecal

6.4. As metodologias de Análise de Giardia sp e Cryptosporidium $\mathrm{sp}$

6.4.1. O Desenvolvimento das Metodologias de Análise de Giardia sp e Cryptosporidium $\mathrm{sp}$

6.4.2. Limitações das Metodologias de Análise de Giardia sp e Cryptosporidium sp, particularmente com relação à Técnica de Concentração por Floculação com Carbonato de Cálcio associada à Microscopia de Imunofluorescència

6.4.3. Importância do controle de qualidade nas análises de Giardia sp e 146 Cryptosporidium $\mathrm{sp}$

6.5. Resultados das Análises de Giardia sp e Cryptosporidium sp e a Legislação Nacional e Internacional sobre os Protozoários de Veiculação Hídrica

6.6. Utilização dos Resultados das Análises de Giardia sp e 152 Cryptosporidium sp em Saúde Pública

7. Conclusões

8. Referèncias Bibliográficas 


\section{RESUMO}

Hachich EM. Avaliação da presença dos protozoários Giardia sp e Cryptosporidium sp em águas superficiais destinadas a captação e tratamento para consumo humano no Estado de São Paulo. São Paulo; 2002 [Tese de Doutorado - Faculdade de Saúde Pública da USP]

Objetivo. Avaliar a presença dos protozoários Giardia sp e Cryptosporidium sp em águas destinadas a captação e tratamento para consumo humano no Estado de São Paulo, como parte do projeto da CETESB (Companhia de Tecnologia e Saneamento Básico do Estado de São Paulo) "Avaliação da Qualidade das Águas Interiores do Estado de São Paulo". Tratam-se de importantes agentes etiológicos de gastroenterites de veiculação hídrica, amplamente disseminados no ambiente e com características que favorecem a transmissão pela água. Métodos. Durante 19 meses foram analisadas 278 amostras de águas superficiais provenientes de 28 pontos de captação de 10 bacias hidrográficas. Foi utilizada a técnica de imunofluorescência, após concentração das amostras por floculação com carbonato de cálcio. Foram igualmente analisados, para verificar-se eventual correlação com esses protozoários, coliformes fecais, estreptococos fecais e Clostridium perfringens. Resultados. Os resultados obtidos indicaram a presença da Giardia sp e Cryptosporidium sp, respectivamente em $27 \%$ e $2,5 \%$ das amostras analisadas, uma porcentagem de positividade inferior àquela relatada na literatura, principalmente para $o$ Cryptosporidium sp. O teste de postos de Spearman revelou uma correlação significativa, entre as concentrações de Giardia sp e os três indicadores de contaminação fecal. Conclusões. Segundo a Legislação Americana de Monitoramento - ICR (Information Collection Rule), em 16 dos 28 pontos de captação avaliados seria necessário realizar análise da água tratada para avaliar a eficiência do tratamento na remoção dos parasitas. A complexidade dos métodos de análise desses parasitas requer rigoroso programa de Controle de Qualidade Analítica. Algumas deficiências técnicas do método ainda limitam a utilização dos resultados do monitoramento em Saúde Pública.

Descritores: Giardia. Cryptosporidium. análises microbiológicas. análises parasitológicas. águas superficiais destinadas a captação e tratamento para consumo humano. 


\section{SUMARY}

Hachich EM. Avaliação da presença dos protozoários Giardia sp e Cryptosporidium sp em águas superficiais destinadas a captação e tratamento para consumo humano no Estado de São Paulo.[Evaluation of Giardia $s p$ and Cryptosporidium $\mathrm{sp}$ in source water from São Paulo State, Brazil] São Paulo; 2002 [Tese de Doutorado - Faculdade de Saúde Pública da USP]

Objective. This work aimed to evaluate the presence of Giardia sp and Cryptosporidium $s p$ in water sources from São Paulo State, Brazil, as part of the project from CETESB (São Paulo State Company for Sanitation and Technology) "Evaluation of Inland Waters from São Paulo State". These organisms are both important agents of waterborne gastroenteritis, being largely disseminated in the environment and share features which favor waterborne transmission. Methods. During 19 months 278 water samples from 28 sites located in 10 watersheds were analyzed. The immunofluorescence assay was used after the concentration of the samples by the calcium carbonate floculation technique Fecal coliforms, fecal streptococci and Clostridium perfringens were also determined in order to verify the existence of correlation between these bacterial indicators and the protozoa. Results. Giardia sp and Cryptosporidium sp were detected in $27 \%$ and $2,5 \%$ of the samples, respectively, a lower figure compared with the results reported by other authors, especially for Cryptosporidium sp. Spearman rank correlation test demonstrated a significative correlation between Giardia sp and fecal indicators concentrations. Conclusions. According to the American Regulation of Monitoring (ICR), treated water from 16 of 28 collection sites should also be analyzed to evaluate if the treatment process could remove the parasites. Due to the complexity of the techniques for Giardia sp and Cryptosporidium $\mathrm{sp}$ analysis a strict Quality Control Program must be implemented and followed by the laboratories performing these assays. Some technical deficiencies of these methods still limit the utilization of the monitoring results for public health decisions.

Descriptors: Giardia sp. Cryptosporidium sp. source water. microbiological analysis; parasitological analysis. 


\section{1 - INTRODUÇÃO}

A contaminação da água de consumo humano representa, ainda em nossos dias, um dos mais significativos riscos ambientais à saúde humana, e apesar dos avanços tecnológicos, a eliminação dos agentes etiológicos, bactérias, vírus e protozoários, constitui um problema para as empresas responsáveis pelo abastecimento de água, mesmo em paises desenvolvidos. Nos Estados Unidos, de acordo com dados do CDC (Centers for Disease Control and Prevention), entre 1980 e 1996, foram relatados 401 surtos de doenças de veiculação hídrica, com mais de 750.000 casos, devendo-se enfatizar ainda que esses números devem estar subestimados, devido a subnotificação. (USEPA, 1998).

Dentre as doenças de veiculação hídrica, são mais freqüentes as gastroenterites, com sintomas tais como diarréia, dores abdominais, vômito e febre, podendo entretanto ocorrer afeç̧ões mais graves como hepatites, úlceras e câncer gástrico, meningites e encefalites.

No Brasil, os dados disponiveis referem-se à incidência de diarréias, de provável origem infecciosa, pela ingestão de água ou alimentos contaminados, as crianças sendo mais atingidas, em todas as faixas etárias, principalmente no Nordeste. Assim, embora a frequência anual de diarréia seja de 1,4 episódios na região Sul, semelhante à dos paises desenvolvidos, ela é de 4 episódios na região Nordeste, igual à dos paises da África e Ásia (MINISTÉRIO DA SAÚDE, 1999).

Dentre os agentes microbianos causadores de gastroenterites, destacam-se atualmente os protozoários Ciardia lamblia e Cryptosporidium parvum pela elevada incidência de casos e devido às suas características de resistência aos tratamentos convencionais e capacidade de permanência no ambiente

Desde 1974 a CETESB desenvolve um projeto denominado Rede de Monitoramento da Qualidade das Águas Interiores do Estado de São Paulo, que engloba atualmente 124 pontos do monitoramento nas 22 UGRHIs (Unidade de Gerenciamento de Recursos Hidricos). São analisados 43 parâmetros fisico-quimicos e biológicos 
A análise dos protozoários Giardia e Cryptosporidium juntamente com a determinação de bactérias indicadoras de contaminação fecal, coliformes, estreptococos e Clostridium perfringens, foi realizada dentro desse projeto, no Setor de Microbiologia e Parasitologia da CETESB, de janeiro de 1999 a setembro de 2000, a cada 2 meses, em 28 pontos de captação de águas para consumo humano, visando avaliar a ocorrência desses organismos nesses mananciais e verificar se existe correlação entre essa ocorrência e algum desses indicadores de contaminação fecal 


\section{1 - Doenças Infecciosas e Água de Consumo Humano}

A proporção global e alcance que as doenças infecciosas vêm atingindo praticamente anulam as melhoras na expectativa de vida e saúde. Essas doenças afetam essencialmente crianças e adultos jovens, sendo responsáveis por mais de 13 milhões de mortes por ano - uma em cada duas mortes nos paises em desenvolvimento. Mais da metade do grupo atingido corresponde a crianças com menos de 5 anos de idade, o restante sendo adultos em idade produtiva. As mortes por doenças infecciosas ocorrem principalmente nos paises em desenvolvimento, dentre as crianças mal-nutridas, que não têm acesso a medicação e a imunização no primeiro ano de vida. Essa situação foi ainda agravada pelos grandes movimentos populacionais da última década, uma vez que os povos refugiados e expulsos de seus paises são particularmente vulneráveis às doenças infecciosas e, podem, igualmente disseminar essas doenças em novas áreas. Outros fatores que contribuem para surtos de doenças infecciosas são a falta de saneamento e de água tratada para a população pobre das grandes cidades (WHO 1999).

A água é essencial para a manutenção da vida, sendo fundamental seu suprimento em qualidade e quantidade adequada para os consumidores. Todos os esforços devem ser dirigidos para obter-se uma água com altos padrões de qualidade. A primeira linha de defesa é a proteção dos suprimentos de água bruta de fontes de contaminação, sendo essa a melhor maneira de garantir-se a boa qualidade da água e preferivel ao tratamento de um suprimento contaminado. Os suprimentos de água bruta devem ser protegidos da contaminação por lixo humano e animal, que podem conter uma variedade de microrganismos patogênicos. Se essa contaminação ocorrer e o tratamento não for adequado, a população estará exposta ao risco de surtos de doenças infecciosas. Os mais susceptiveis às doenças de veiculação hídrica serão os recém-nascidos, crianças pequenas, doentes, idosos, pessoas com a saúde debilitada ou aquelas que vivem em condições sanitárias insatisfatórias,. Para esses grupos, as doses infectantes são significativamente inferiores à da população adulta em condições normais de saúde. A contaminação microbiana da água difere da contaminação química num ponto fundamental: as doenças microbianas, além da transmissão através da água, também podem ser transmitidas por contato pessoa a 
pessoa, aerossóis e através dos alimentos, criando-se assim um reservatório de casos e portadores. $O$ fornecimento de uma água de boa qualidade microbiológica irá reduzir a possibilidade de transmissão através dessas outras vias (WHO 1993).

Embora as doenças de veiculação hídrica estejam sob certo controle nos Estados Unidos e Canadá, elas continuam a ser registradas nesses paises, e apesar da mortalidade e morbidade nào serem tão elevadas quanto nos paises da América Latina, sua ocorrência serve como um alerta de que nenhum pais pode ser complacente sobre a vulnerabilidade dos sistemas de água tratada à contaminação microbiana (OTTERSTETTER e CRAUN 1997).

Nos Estados Unidos, em 1990, um grupo de especialistas constituido pelo Congresso americano (EPA's Science Advisory Board - SAB) reconheceu que a contaminação da água de consumo humano é um dos mais importantes riscos ambientais, e que os microrganismos patogênicos constituem o principal risco à saúde e o maior desafio aos sistemas responsáveis pelo abastecimento de água (USEPA 1998)

A maioria dos microrganismos patogênicos de veiculação hídrica causam as chamadas gastroenterites, doenças caracterizadas por sintomas tais como diarréia, desconforto abdominal, cólicas, vômito, náuseas e febre. Outros organismos podem ocasionar doenças mais graves, como por exemplo, hepatite, câncer gástrico, úlcera péptica, meningite, encefalite e várias outras patologias (WHO 1993)

As diarreias são responsáveis, anualmente, pela morte de cerca de 2 milhões de crianças de menos de 5 anos. Nos paises em desenvolvimento elas correspondem a 1,5 milhões de casos nessa faixa etária, principalmente em áreas sem saneamento e água tratada. Em alguns paises doenças como a cólera atingem tanto adultos como crianças, mas a febre tifóide e as infecções por rotavirus são as principais causas de diarréia nas crianças (WHO 1999)

Dentre os surtos de gastroenterite com associação epidemiológica à água, estimase que $19 \%$ são atribuiveis aos parasitas, $13 \%$ são de origem bacteriana, $11 \%$ são causadas por produtos químicos, $8 \%$ são virais e $1 \%$ têm outras causas conhecidas, os restantes $49 \%$ sendo de causas desconhecidas (CDC, 1994, citado por LINDQUIST 1999) 


\subsection{1 - As Gastroenterites causadas pelos Protozoários Giardia e Cryptosporidium}

\section{a) Giardíase}

A giardiase é uma gastroenterite causada pelo protozoário unicelular flagelado Giardia lamblia. denominado mais comumente Giardia intestinalis na Europa Os protozoários pertencentes a esse gênero são considerados organismos relativamente primitivos, que vivem e se reproduzem de forma assexuada no epitélio intestinal do hospedeiro. Com base apenas em diferenças detectáveis por microscopia comum são descritas três espécies de Giardia: G. agilis de anfibios, G. muris de roedores, e G. lamblia (também chamada de $G$. duodenalis e $G$. intestinalis) de várias espécies de mamiferos. Através de microscopia eletrônica, são reconhecidas a $G$. ardeae de lagartos. e a $G$. psitacci de psitacídeos. A G. lamblia é encontrada em várias espécies de animais domésticos, incluindo cães, gatos e em animais silvestres, como por exemplo os castores, que já foram responsáveis por surtos de veiculação hídrica de giardiase. Através da utilização de técnicas enzimáticas e de biologia molecular foram caracterizadas variantes genéticas do parasita, que também diferem em caracteristicas fenotípicas, tais como antigenicidade, virulência e especificidade do hospedeiro Para a G. lamblia existem pelo menos 5 genótipos principais, o A (mais comum do ponto de vista geográfico) e o B. isolados de várias espécies de mamiferos, incluindo seres humanos, havendo assim potencial para transmissão zoonótica. Os outros três genótipos são mais específicos de gado, cães e roedores (THOMPSON 1999).

No hospedeiro suscetível, após ingestão dos cistos, a forma infectante e ambientalmente resistente, ocorre a desencistação no intestino delgado, liberando os trofozoitos que se multiplicam por divisão binária longitudinal. Os trofozoítos permanecem na luz do intestino delgado proximal, onde podem se aderir à mucosa através de uma ventosa central. A encistação ocorre quando os parasitas passam atraves do cólon, e os cistos são a forma encontrada nas fezes normais (nãodiarréicas). Os cistos podem sobreviver vários meses na água fria, são relativamente resistentes à cloração e à luz ultravioleta. A fervura é bastante eficaz na destruição 
dos cistos de Giardia, mas alguns podem resistir ao congelamento por alguns dias. A infecção pode ser causada por doses baixas, de até 10 cistos, podendo ocorrer pelo contato direto, muito comum entre crianças em creches, através da ingestão de água ou alimentos contaminados, também tendo sido relatada a transmissão pelo contato homossexual masculino. Cães, gatos e vários animais silvestres podem ser infectados, e alguns surtos de veiculação hídrica da doença já foram atribuidas aos castores, mas a importância dos animais como reservatório da doença não está bem definida (ORTEGA et al. 1997).

Os sintomas mais comuns da gastroenterite provocada pela Giardia, que se manifestam 1 a 2 semanas após a ingestão dos cistos, são diarréia, flatulência, desconforto abdominal, perda de peso, cólicas, náusea, má-absorção, esteatorréia, fadiga, anorexia e calafrios. O sintoma mais típico é diarréia, mas podem ocorrer infeç̧ões assintomáticas, principalmente em individuos previamente infectados. Normalmente a doença dura 1 a 2 semanas mas há casos de infecções crônicas, com duração de meses ou anos. Os cistos podem ser excretados nas fezes intermitentemente durante semanas e meses, o que resulta num prolongado periodo de transmissão. O tratamento de escolha é o metronidazol, mas a furazolidona e o tinidazol também são bastante utilizados.

O diagnóstico da doença é realizado pela deteç̧ão dos cistos, ou com menor frequência dos trofozoitos, nas fezes dos pacientes infectados. As amostras podem ser concentradas e coradas, e a sensibilidade da detecção pode ser melhorada repetindo-se as coletas e exames, uma vez que os organismos são eliminados esporadicamente nas fezes.

A $G$. lamblia foi descrita por Lamb em 1859, e foi considerada por muito tempo um comensal, pois era encontrada em grandes quantidades nas fezes de indivíduos que não apresentavam nenhum sintoma. A doença era comumente denominada "diarréia dos viajantes". Atualmente, a giardiase é comum em todos os paises, principalmente em locais nos quais as condições sanitárias são insatisfatórias e há deficiência do suprimento de agua tratada. A doença e sazonal, com picos de incidência no final do verão, conforme relatado no Reino Unido, Estados Unidos e México, essa sazonalidade nào sendo observada em creches. A prevalência da Giardia em exames parasitológicos de fezes varia de $2 \%$ a $5 \%$ em paises 
industrializados e de $20 \%$ a $30 \%$ em paises em desenvolvimento e chega a $35 \%$ em crianças que freqüentam creches nos Estados Unidos (ORTEGA et al.1997). É o parasita identificado com maior frequêencia nos exames parasitológicos de fezes nos Estados Unidos (KAPPUS et al. 1994).

Em 43 estados americanos a ocorrência de giardíase deve ser relatada, mas não se trata de uma doença de notificação nacional. Em 1992, em virtude de sua importância para a Saúde Pública foi atribuido um código para a doença de forma que todos os estados pudessem relatar espontaneamente sua ocorrência ao CDC através do "National Eletronic Telecommunications System for Surveillance (NETSS). FURNESS et al 2000, relatam os resultados desse levantamento: O número anual de casos de giardíase relatados variou de $12.793 \mathrm{em} 1992$ a $27.778 \mathrm{em}$ 1996. Em 1997, o número de casọs por 100.000 habitantes nos estados americanos variou de 0,9 a 42,3 , sendo que 10 estados relataram mais de 20 casos por 100.000 habitantes. Em 1997, o Estado de Nova Iorque, incluindo a cidade de Nova Iorque relatou o número mais elevado de casos ( 3.673 ou 20,3 casos por 100.000 habitantes) totalizando $14,5 \%$ dos casos do pais, embora em Vermont tenha ocorrido a taxa de incidência mais elevada (42,3 casos por 100.000 habitantes). Esses dois estados têm programa ativo de vigilância para giardiase. A distribuição dos casos de doença entre os sexos é igual, e, quanto à idade, o maior número de casos se dá entre as crianças de 0 a 5 anos, seguido do grupo de 31-40 anos. Nessas duas faixas etárias, a maior parte dos casos ocorre no verão e inicio do outono, indicando que a transmissão é predominante durante o verão. Esse padrão de ocorrência da doença pode estar relacionado ao maior periodo de exposição recreacional na estação quente e a elevada freqüencia de crianças pequenas em piscinas públicas, o que é também coerente com a baixa dose infectante da Giardia, sua elevada prevalência em crianças que usam fraldas, o prolongado periodo de excreção dos cistos e sua elevada resistência ambiental. Com base na vigilância realizada nesses estados, estima-se a ocorrência de um total de 2,5 milhões de casos de giardiase por ano nos Estados Unidos

Devido a várias razões, conforme relatado por THOMPSON 2000, a giardíase é hoje considerada uma parasitose re-emergente. A primeira dessas razões diz respeito ao grande número de surtos de diarréia em creches. Nos paises desenvolvidos, a 
utilização cada vez maior dessas instituições é um dos motivos da re-emergência da doença. Em virtude de mudanças sociais e econômicas, um número cada vez maior de crianças pequenas são colocadas em creches, sendo assim expostas à infeç̧ão, numa idade na qual elas são, do ponto de vista imunológico, mais sensíveis à infecção, além da falta de hábitos de higiene adequados. Um outro motivo apontado como causa de re-emergência dessa parasitose diz respeito a altas taxas de infecção por Giardia em animais domésticos, principalmente em bezerros, nos quais ela causa diarreia e parece ter maior prevalência do que observado anteriormente, com possiveis conseqüências importantes para Saúde Pública. Esses animais constituemse um importante reservatório da doença, e o parasita isolado dos mesmos tem morfologia e antigenicidade semelhante aos parasitas isolados de humanos. Animais de estimação, tais como cães e gatos apresentam também elevadas taxas de infecção pelo parasita. Nesses animais verificou-se um declinio na infecção por Toxocara, possivelmente pelo uso rotineiro de antihelminticos, paralelamente a um aumento na prevalência da Giardia. que não é afetada por essas drogas. Uma outra explicação, para maiores taxas da giardiase em cães e gatos, é a melhoria dos processos de diagnóstico. Essa ocorrência aumentada nesses animais tem obviamente um implicação importante para Saúde Pública, devido ao potencial para transmissão zoonótica dos animais de estimação para seus donos. 


\section{b) Criptosporidiose}

A doença é causada pelo parasita Cryptosporidium parvum. um protozoário do grupo dos coccídeos ao qual pertencem vários outros organismos importantes do ponto de vista médico, tais como o Toxoplasma gondii, Isospora belli e espécies de Plasmodium. Todas as espécies do gênero Cryptosporidium são parasitas intracelulares obrigatórios, com fases assexuada e sexuada de reprodução. Além do C. parvum existem mais 9 espécies reconhecidas do protozoário, o $C$. bailey e $C$. meleagridis detectados em pássaros, $C$. felis em gatos, C. muris descrito predominantemente em camundongos, $C$. wairi em cobaias, $C$. andersoni em gado, C. nasorum em peixes, $C$. serpentis em répteis e $C$. saurophilum em lagarto (FAYER et al. 2000)

THOMPSON 1999, numa revisão sobre as caracteristicas genéticas dos parasitas Giardia e Cryptosporidium descreve os genótipos do C parvum. Estudos realizados com amostras de fezes de vários locais demonstraram que humanos são suscetiveis a dois principais genótipos: um genótipo denominado Humano, encontrado somente em humanos, e um genótipo zoonótico, Gado, encontrado tanto em animais como por exemplo, gado, ovelhas, cabras, bem como em humanos. Este último genótipo é igualmente infeccioso para outros animais, tais como roedores de laboratório. Resultados da análise através de PCR de 511 amostras de fezes, demonstraram que $20 \%$ apresentavam o $C$ parvum de genótipo Gado, enquanto os demais correspondiam ao genótipo Humano. FAYER et al 2000 revêm extensivamente a epidemiologia do Cryptosporidium, e discutem com detalhes os estudos realizados para a caracterização dos diferentes genótipos do C. parvum, através de técnicas bioquimicas (análise de isoenzimas) e de biologia molecular principalmente, relatando a contribuição desses estudos para a caracterização desses dois genótipos. Os autores relatam igualmente a identificação dos genótipos Humano e Gado em alguns surtos de criptosporidiose, o que permitiu determinar a origem humana ou animal da contaminação. Possivelmente, pacientes com imunodepressão sejam mais susceptiveis aos dois genótipos, e também a outras espécies de Cryptosporidium, como por exemplo o C. felis e o C. meleagridis que foram detectados nas fezes desses indivíduos. São igualmente descritos genótipos do C. parvum específicos de 
outros hospedeiros, tais como camundongos, porcos, marsupiais e o furão. Um terceiro genótipo, possivelmente relacionado ao $C$ meleagridis, foi identificado recentemente, num estudo realizado no Reino Unido, em $0,7 \%$ de cerca de 2000 amostras de pessoas envolvidas em surtos de veiculação hídrica da doença (PEDRAZA-DIAS et al. 2001)

$\mathrm{O}$ ciclo do protozoário inicia-se pela ingestão e possivelmente a inalação de oocistos do parasita, eliminados nas fezes (possivelmente também nas secreç̃̃es respiratórias) dos hospedeiros infectados. Após desencistamento no organismo, são liberados os 4 esporozoitos que parasitam as células epiteliais do trato gastrointestinal (ou outros tecidos como por exemplo o trato respiratório). Nessas células, ocorre a multiplicação assexuada (esquizogonia ou merogonia) e então a multiplicação sexuada (gametogonia). Após a fertilização dos macrogamontes (fêmeas) pelos microgamontes (machos), desenvolvem-se os oocistos que esporulam no hospedeiro infectado e são em seguida excretados, podendo ocorrer a autoinfecção nessa fase

As múltiplas reciclagens do organismo na fase assexuada e a auto-infecção têm como consequêencia uma infecção intensa e eliminação de grandes quantidades de oocistos nas fezes dos infectados. As doses infectantes, conforme experimentos realizados em adultos sadios sem evidências sorológicas de infecção anterior com $C$. parrum, podem ser tão baixas quanto 30 oocistos (DUPONT et al. 1995). Essa dose pode entretanto variar com fatores tais como origem, idade e viabilidade dos oocistos. sua história de exposição ao estresse ambiental e outros fatores pouco elucidados, como por exemplo a virulência. Estudos em carneiros quantificaram a dose infectante de Cryptosporidium associada com a exposição à água contaminada, concluindo que a mesma pode ser de até mesmo 1 a 5 oocistos (MEINHARDT et al. 1996)

A infecção ocorre pela ingestão de água ou alimentos contaminados com os oocistos, no contato pessoa a pessoa e também através do contato animal-pessoa, sendo essa última bastante comum através do gado leiteiro, uma vez que esses animais, principalmente os bezerros eliminam grandes quantidades de oocistos nas fezes. A transmissão pessoa a pessoa pode ocorrer com freqüência entre crianças, principalmente aquelas ainda utilizando fraldas, em creches 
Os oocistos do protozoário são extremamente resistentes à maior parte dos desinfetantes, inclusive ao cloro e também a várias outras condições ambientais adversas, podendo permanecer em estado dormente no solo ou e água por vários meses (KORICH et al. 1990, ROBERTSON et al. 1992).

O sintoma mais comum da doença, tanto em imunocompetentes como em imunodeprimidos è a diarréia aquosa e abundante, as fezes se apresentando esverdeadas ou incolores. Outros sintomas que podem ocorrer são cólicas abdominais, vômito, dores de cabeça, febre baixa, dores musculares, mal estar, anorexia e perda de peso. Nos pacientes imunocompetentes a doença é auto-limitada tendo a duração de 7 a 14 dias, mas nos pacientes com AIDS ela é crônica e todos os sintomas são mais graves.

Não se dispõe até o momento de tratamento efetivo, com antibióticos ou outros tipos de medicamentos quimoterápicos, embora mais de 80 drogas tenham sido testadas. Assim o tratamento dos doentes limita-se a reidratação oral e endovenosa.

O diagnóstico da doença é realizado pela detecção dos oocistos nas fezes dos pacientes, utilizando a flotação com soluções de açúcares para concentração dos organismos e coloração com corantes ácidos para identificação. Estão também disponiveis no comércio "kits" contendo anticorpos monoclonais conjugados a fluoresceina. Segundo vários autores (Casemore 1992, 1993, 1994 e Casemore et al. 1993 ) citados por MEINHARTD et al. 1996, a identificação exata dos oocistos de Cryptosporidium requer muita habilidade, experiencia e tecnicas internas de controle de qualidade laboratorial

O cryptosporidium parvum foi reconhecido como patogênico em humanos pela primeira vez em 1976, e, desde essa data até 1982 poucos casos foram registrados, geralmente em pacientes imunodeprimidos. A partir de 1982, o número de casos aumentou bastante, como parte da epidemia de AIDS. No inicio a maior parte dos casos era relatada dentre os aidéticos, mas com o auxílio de novos métodos de diagnóstico sua ocorrência em pacientes imunocompetentes começou a ser reconhecida. Trata-se atualmente da causa mais comum de diarreia nos pacientes com AIDS, estimando-se que a taxa anual de criptosporidiose nesses seja de $5 \%$ a 10\% (JURANEK 1999). 
Nos paises desenvolvidos, estima-se uma prevalência de $0,6 \%$ a $20 \%$, enquanto que nos paises em desenvolvimento esses números seriam de $4 \%$ a até $30 \%$ (MEINHARTD et al. 1996).

\subsection{2 - A Ocorrência de Giardíase e Criptosporidiose no Brasil}

WEIKEL et al., 1985 estudaram a ocorrência de oocistos de Cryptosporidium nas fezes de pacientes com diarréia aguda no nordeste do Brasil. Tratou-se de um estudo prospectivo, que incluiu 117 pacientes e 22 controles, tendo sido observada e confirmada a presença do protozoário nas fezes de 9 pacientes e em nenhum dos controles. De acordo com esses resultados o (ryptosporidium seria o $4^{\circ}$ agente etiológico de diarreia nessa região, seguindo-se a Escherichia coli(23,5\%), rotavírus $(19,4 \%)$ e Shigella sp ( $8 \%)$. A maior parte dos pacientes eram crianças (todos, exceto um, tinham três anos ou menos), seis pertenciam ao sexo feminino e os demais eram meninos. Em todos a doença ocorreu entre os meses de outubro e março, isto é, ao final da estação seca e no inicio da estação chuvosa. Em 4 dos 9 casos o Cryptosporidum era o único organismo enteropatogênico detectado, em seis casos foram identificados outros agentes potencialmente causadores de diarréia. As condições de habitações de 8 pacientes eram bastante precárias, não havendo disponibilidade de água corrente e instalações sanitárias. Para os autores os dados desse estudo e da literatura sugerem que o protozoário pode ser responsável por uma proporção significativa de casos de diarréia não diagnosticados em areas em desenvolvimento, sendo necessários novos estudos prospectivos para determinar formas de transmissão, distribuição e gravidade da doença em crianças desses paises.

NEWMAN et al., 1993, estudaram a doença tentando elucidar as fontes ambientais de contaminação em uma favela de Fortaleza, cidade na qual os autores já haviam detectado uma elevada proporção de casos de diarreia positivos para Cryptosporidium. isto é $8 \%$ (WEIKEL et al., 1985) e 14,5\% (dados não publicados). O protozoário foi pesquisado nas fezes de animais domésticos e em filtrados de vários tipos água consumida pela população local, tendo sido essa pesquisa realizada na estação seca e chuvosa, uma vez que nos trabalhos anteriores havia sido 
observada a sazonalidade da doença. Somente $47 \%$ das casas eram abastecidas com suprimento público de água as demais utilizavam água de outras origens. A maior parte das moradias não tinham instalações sanitárias nem coleta de esgotos. Em $45 \%$ das casas havia pelo menos um animal, que permanecia na própria casa ou no quintal, geralmente cães e gatos, mas podendo ser também galinhas, patos e porcos. Das 64 amostras de fezes coletadas durante a estação seca, (setembro-dezembro de 1990), quatro (6,3\%) foram positivas para Cryptosporidium, enquanto que nas 63 amostras coletadas durante a estação chuvosa (março-maio de-1991) esse número elevou-se para $9(14,3 \%)$. As amostras positivas foram mais comuns nos cães. Durante o periodo de estudo, foram identificadas 16 famílias com casos de criptosporidiose, e em dois desses casos, haviam animais com fezes positivas para o protozoário. Nas amostras de água, que incluiram poços abertos e fechados, e água corrente da cidade, foi obtida uma porcentagem de $22,2 \%$ de resultados positivos para o protozoário $(n=4)$. Segundo os autores, considerando-se que os animais podem servir de reservatório para o Cryptosporidium, com potencial para contaminar as fontes de água, os resultados obtidos podem explicar a elevada incidência de criptosporidiose nas crianças das faixas pobres da população dessa comunidade.

Nessa mesma favela de Fortaleza, NEWMAN et al., 1994, através de um estudo de coorte prospectivo estudaram a importância de transmissão da critptosporidiose em domicílios com um caso identificado da parasitose. Os casos secundários da doença, a maior parte dos quais não apresentava diarreia, foram diagnosticados através de exame parasitológico de fezes ou soro-conversão, e ocorreram em 18 $(58 \%)$ dos 31 domicílios estudados, envolvendo 30 pessoas, resultando numa taxa de transmissão de 19\%. Das 202 pessoas, que tiveram pelo menos uma amostra de soro analisada, 191 (94\%) apresentaram anticorpos (IgG ou IgM) para o Cryptosporidium.

De acordo com ZU et al., 1994, que estudou a soroprevalência de anticorpos para Cryptosporidium em crianças com menos de 4 anos de idade em uma comunidade de baixa renda em Fortaleza, mais da metade dessas crianças adquirem anticorpos para o parasita no segundo ano de vida. Assim, nos 40 soros avaliados, a presença de anticorpos para Cryptosporidium (IgG) foi de $75 \%$ Na maior parte dos domicílios onde essas crianças residiam as instalações sanitárias eram fossas e suprimentos de agua eram públicos. Essa mesma pesquisa tambèm foi realizada com crianças de 
idade inferior a 16 anos de uma comunidade rural na China e pacientes com 29 anos ou menos de um hospital da Virginia nos Estados Unidos, obtendo-se prevalências de anticorpos muito menores que aquelas observadas entre as crianças brasileiras.

GENNARI-CARDOSO et al., 1996 pesquisaram a presença de Cryptosporidium $\mathrm{sp}$ nas fezes diarréicas de crianças com zero a 12 anos, em tratamento nas unidades médicas da Universidade Federal de Uberlândia ou em clínicas particulares dessa cidade. Foram detectados oocistos do protozoário nas fezes de $4,26 \%$ das 94 crianças incluidas no estudo, três casos em plena estação chuvosa (novembro e dezembro) e um caso ao final da mesma (março).

Quanto aos pacientes aidéticos, a prevalência de Cryptosporidium sp foi estudada por SAUDA et al, 1993. Nesse trabalho os oocistos do parasita foram encontrados em $19,1 \%$ dos exames realizados em 131 pacientes (média de 2,1 amostras por paciente) do Centro de Referência para AIDS, na cidade de Santos, no Estado de São Paulo. Os mesmos autores também relatam a ocorrência do protozoário nas fezes de 4 dentre 8 crianças com diarréia, num estudo sobre gastroenterite realizado em creches do Estado de São Paulo

WUHIB et al., 1994 verificaram que o Cryptosporidium parvum e outros microsporidios são importante causa de diarréia em pacientes HIV positivos, num estudo realizado em Fortaleza, de 1990 a 1992 . Esses autores observaram igualmente uma associação entre a infecção por Cryptosporidium e a estação chuvosa, o que de acordo com os mesmos sugere que água contaminada seja uma importante fonte de contaminação

TOMPS 1998, estudou a ocorrência do parasita em fezes de individuos com diarreia $(n=75)$ residentes em Perus, no estado de São Paulo, obtendo uma positividade de $24,0 \%$, com prevalência no grupo etário de 1 a 3 anos.

Quanto à giardiase, LUDWIG et al., 1999 observaram que o enteroparasita mais encontrado em exames realizados em postos de atendimento sanitário (PAS) na população de Assis, Estado de São Paulo, no periodo de 1990 a 1992 foi a Giardia intestinalis $(8,7 \%)$. Nesse trabalho, estabeleceu-se uma correlação entre as condições de saneamento básico, expresso pelo número de ligações de água e esgoto, e a frequência de parasitoses. Houve queda nessa freqüência de parasitose nos PAS entre 
1990 e 1992, coincidindo com o aumento do número de ligações de água e esgoto nestas regiões.

\subsection{3 - Giardia e Cryptosporidium como Agentes Causadores de} Gastroenterites de Veiculação Hídrica

Há bastante tempo a contaminação da água com microrganismos de origem fecal é causa reconhecida de gastroenterites de veiculação hídrica. A ocorrência de surtos de transmissão hídrica de cólera, febre tifóide e paratifóide, sérios problemas de saúde pública nos Estados Unidos e Reino Unido no início do século, diminuiu substancialmente com o aperfeiçoamento dos processos de tratamento da água, principalmente com a cloração. Permaneceram a ser relatados entretanto os surtos de gastroenterites de veiculação hídrica, desta vez por organismos resistentes à desinfecção, tais como Giardia e Cryptosporidium (ROSE 1997, FURTADO et al. 1998). Para SMITH 1998, esses protozoários tornaram-se importantes agentes de doenças de veiculação hídrica nos paises desenvolvidos devido principalmente a três motivos: tratam-se de doenças autóctones, com baixas doses infecciosas, a magnitude da contaminação de origem ambiental com cistos e oocistos infecciosos é significativa no ambiente aquático, e, finalmente, as reduzidas dimensões dos cistos e ooocistos e sua resistência aos desinfetantes dificultam sua remoção pelos processos de tratamento da água.

MARSHALL et al. 1997, relatam que a Giardia lamblia é o agente etiológico identificado com maior frequência nos surtos de doenças de veiculação hídrica, e a maior parte desses eventos está associado ao consumo de água superficial, ou água subterrânea sob a influência de água superficial, não filtrada e clorada de forma inadequada

De 1983 a 1999, foram relatados 69 surtos de criptosporidiose nos Estados Unidos, Reino Unido, Canadá, Japão, N. Zelândia e Austrália todos associados ao consumo ou contato recreacional com água contaminada. Dentre esses episódios, destaca-se o de Milwaukee. Estados Unidos, em 1993, que atingiu mais de 400.000 pessoas. Todos esses surtos ocorreram em comunidades nas quais a qualidade da 
água atendia aos padrões de potabilidade exigidos pela legislação, e em três deles o tratamento de água superficial captada incluia filtração. Na última década vários surtos de criptosporidiose foram atribuídos ao contato recreacional, em piscinas públicas e parques aquáticos. Muitas dessas piscinas são freqüentadas por crianças que ainda utilizam fraldas, as quais têm elevada prevalência de infecção pelo Cryptosporidium parvum. Esse tipo de transmissão é ainda favorecido por algumas características desse protozoário, ou seja, seu tamanho reduzido, baixa dose infectante e resistência aos desinfetantes, como o cloro. Além disso, indivíduos infectados excretam grandes quantidades dos oocistos por períodos prolongados.

FURTADO et al, 1998, relatam os surtos de doenças de veiculação hídrica que ocorreram no Reino Unido entre janeiro de 1992 e dezembro de 1995: dentre esses surtos, 19 (73\%) estiveram associados à água de consumo humano, 4 (15\%) ao contato recreacional, um ao consumo de bebidas contendo gelo contaminado, outro ao consumo acidental de água de uma estação de tratamento de esgotos enquanto que o último foi causado pela imersão em um rio durante canoagem. $\mathrm{O}$ protozoário Cryptosporidium foi o agente causal de 10 surtos associados ao consumo de água de torneira fornecida por sistemas públicos de abastecimento e pode ser detectado na água tratada em 3 dessas ocorrências. Num desses surtos, 575 casos foram confirmados. com 25 pacientes hospitalizados. O consumo de água de sistemas privados de abastecimento foi implicado como causa de 9 surtos: em um deles o agente etiologico era a (ilardia, cujos cistos puderam ser detectados na água armazenada em um reservatório, enquanto que nos dois outros o organismo envolvido era o Cryptosporidium. Nos 4 surtos atribuidos ao contato recreacional o protozoario Cryptosporidium foi implicado, tendo sido detectado em uma das piscinas. Desses 4 casos, 3 referiam-se a piscinas infantis ou a piscinas utilizadas por crianças quando da ocorrência da doença. 


\subsubsection{1 - Surtos de Giardíase e Criptosporidiose nos Estados Unidos associados à Água de Consumo Humano}

Entre 1965 e 1984, 90 surtos e 23.776 casos de giardiase foram relatados, sendo $69 \%$ dos surtos e $74 \%$ dos casos associados ao consumo de água de sistemas públicos de tratamento, a maioria dos quais utilizavam águas superficiais com cloração ou filtração inadequadas (KENT et al., 1988, CRAUN, 1986).

Segundo LEVINE et al. 1990, de 1986 a 1988 a G. lamblia foi responsável por 9 (18\%) dos 50 surtos de gastroenterite de veiculação hídrica relatados ao CDC, grande parte dessas ocorrências associadas ao consumo de água tratada por simples cloração. O maior desses episódios atingiu cerca de 500 pessoas e, foi provavelmente causado por mal funcionamento do equipamento utilizado para cloração. Num surto de criptosporidiose ocorrido na Georgia em 1987, 13.000 pessoas contrairam a doença após o consumo de água filtrada e clorada de um sistema público de abastecimento. Foram detectados oocistos do protozoário na água, que atendia aos padrões estaduais e federais de potabilidade.

No periodo compreendido entre 1989 e 1990 foram relatados 26 surtos de gastroenterite atribuidos ao consumo de água, conforme descrito por HERW ALDT et al 1992. A Giardia lamblia foi a causa de 7 dos 12 surtos nos quais um agente etiológico pode ser identificado. Esses surtos afetaram cerca de 697 pessoas, tendo ocorrido em Nova lorque (três), Colorado (dois), Vermont (um) e Alaska (um). Em seis desses surtos a água tinha sido captada de fontes superficiais e no outro a fonte subterrânea era sujeita a contaminação superficial devido à erosão do solo. $\mathrm{O}$ tratamento foi ineficiente em 6 desses acontecimentos (cloração, que não tem eficácia contra os cistos do parasita e filtração inadequada). No outro surto, que ocorreu num acampamento, foi consumida água contaminada de um rio, porque o suprimento normalmente utilizado (água de um poço) estava congelado.

MOORE et al. 1994, relatam que entre 1991 e 1992, nos Estados Unidos, dentre os 34 surtos de doença de veiculação hídrica registrados, Giardia lamblia ou Cryptosporidium foram identificados como agentes etiológicos em 7 (21\%). Quatro surtos de giardiase afetaram cerca de 123 pessoas, sendo dois associados com sistemas comunitários e dois com sistemas não comunitarios de abastecimento de 
água Em um dos surtos, a população era suprida por água superficial que não era submetida a filtração, e na qual foram detectadas pequenas quantidades de cistos de Giardia. Entretanto, não foram detectados coliformes na água captada e nem na água das torneiras. Neste sistema, a água final não havia sido clorada adequadamente. Os outros três surtos de giardíase estiveram associados ao consumo de água subterrânea: Num deles, houve uma conexão cruzada com água superficial contaminada. Em outro, foram observados coliformes em uma amostra de água, mas não foi possivel determinar-se a origem da contaminação. No terceiro caso, no qual tratava-se de água de poço clorada, não foi identificado qualquer tipo de problema. Três surtos de criptosporidiose atingiram um total estimado de 3.551 pessoas. No primeiro surto foi responsabilizada uma fonte que supria uma comunidade de 80.000 pessoas. Pequenas quantidades de oocistos de Cryptosporidium foram encontradas em amostras de água coletadas durante um periodo de 2 semanas, mas essa ocorrência não se repetiu durante as dez semanas subsequentes. Eventualmente, eram detectados baixos níveis de coliformes, algas e diatomáceas, o que sugere que a fonte sofria a influência de água superficial. $O$ outro surto foi ocasionado por problemas na filtração da água superficial captada. $O$ rio recebia descargas de esgoto, e sua qualidade piorou, devido à baixa vazão, durante a estação seca. Não foi possivel avaliar se a água filtrada continha oocistos, uma vez que a mesma continha grande quantidade de partículas semelhantes a oocistos, isto é algas. A turbidez da água efluente filtrada estava elevada, embora os niveis médios atendessem à legislação. Nesses dois surtos, a revisão dos documentos sobre a qualidade da água demonstrou que nos últimos anos os padrões para coliformes e turbidez vinham sendo obedecidos. No terceiro surto, um poço nào-comunitário deu origem aos casos, no qual foram detectados oocistos de coccidos que poderiam ser de Cryptosporidium, algas e diatomáceas, o que demonstrou que o poço estava sob a influência de águas superficiais. $\mathrm{Na}$ água final, não haviam coliformes e as concentrações de cloro eram suficientes para inativar bactérias, mas não os oocistos de Cryptosporidium, reconhecidamente mais resistentes ao cloro

Dentre os 30 surtos de doenças de veiculação hidrica compilados pelo CDC, nos Estados Unidos, entre 1993 e 1994, conforme relatado por KRAMER et al 1996, 10 $(33,3 \%)$ foram causados pelos protozoários Giardia lamblia ou Cryptosporidium. Os 
cinco surtos de criptosporidiose atingiram um total estimado de 403.271 pessoas. Um desse surtos, em Clark County, Nevada, durou cerca de 7 semanas e foi inicialmente observado entre os portadores de HIV. Um dos principais fatores que contribuíram para detecção do surto foi que a criptosporidiose é uma doença de notificação obrigatória nesse estado e que muitas pessoas com AIDS viviam em Clark County. Nesses pacientes, como a doença é extremamente grave, é normalmente requisitado o exame laboratorial para deteç̧ão dos oocistos do parasita, esse exame não sendo feito rotineiramente pela maior parte dos laboratórios. Pessoas não infectadas pelo virus também contrairam a doença, mas não são disponiveis estimativas sobre o número total de doentes. Como não foi estabelecida relação entre a água de consumo e a doença durante o surto, não foi expedida a recomendação para fervura da água. A água que abastecia a cidade, filtrada e clorada, era proveniente do Lago Mead, e apresentava boa qualidade antes e durante o surto, melhor mesmo que o exigido pelos padrões vigentes. Embora não tenham sido detectados oocistos de Cryptosporidium na água bruta ou tratada, durante o surto, oocistos presuntivos foram encontrados posteriormente, nessas amostras de água e também na água de retro-lavagem dos filtros.

Um outro surto de criptosporidiose foi causado pela água filtrada e clorada de um lago, os protozoários Giardia e Cryptosporidium tendo sido encontrados na água bruta do lago mas não na tratada.

Os dois outros surtos de criptosporidiose estiveram associados ao consumo de água de poços, contaminados por água superficial e esgoto tratado de um sistema de irrigação. Em ambos os casos foram detectados oocistos presuntivos de Cryptosporidium e coliformes fecais ou totais na água dos poços.

Os cinco surtos de giardiase atingiram um total estimado de 385 pessoas. Dois desses surtos ocorreram devido à água superficial apenas clorada, não submetida a processos de filtração. Em um desses surtos, uma amostra de água de um reservatório foi positiva para Giardia, enquanto que no outro a água final apresentava coliformes totais. No terceiro surto, houve uma contaminação cruzada entre água tratada e esgotos, numa instituição penitenciária. Elevadas concentrações do protozoário foram encontradas na agua de torneira. No quarto surto tratava-se de um poço clorado, contaminado com esgoto, Giardia e Escherichia coli tendo sido detectadas 
na água de torneira. No último surto relatado de giardiase, houve a contaminação de um poço pela água de um riacho, o protozoário foi encontrado na água do poço e coliformes fecais no poço e na água de torneira.

Nessa época foi registrado o maior surto de doença de veiculação hidrica desde 1920 quando esse levantamento vem sendo realizado nos Estados Unidos: em Milwaukee, ao final de março e início de abril de 1993, estima-se que 403.000 pessoas contrairam criptosporidiose, das quais 4.400 foram hospitalizadas. A doença foi confirmada em mais de 600 pessoas, não tendo sido encontrado nenhum outro organismo patogênico ao qual pudesse ser atribuido o evento. Mais de metade das pessoas que recebiam água da estação de tratamento sul da cidade ficaram doentes, o dobro de incidência registrado na área residencial suprida pela estação norte. A água que abastecia a cidade, era filtrada e clorada, proveniente do Lago Michigan. Degelo e chuvas teriam levado contaminação de origem agricola para o lago, fato que associado a problemas no processo de coagulação-filtração da estação de tratamento de água que supria a regiâo sul da cidade teria permitido a permanência dos oocistos de Cryptosporidium na água. Foi registrado um aumento na turbidez da água tratada, atingindo um máximo de 1,7 unidades nefelométricas de turbidez, mas atendendo aos padrões vigentes de qualidade bacteriológica (ausência de coliformes). Os oocistos do protozoário também foram encontrados no gelo preparado durante o surto. Fatores que contribuiram para o reconhecimento da epidemia foram elevado absenteísmo entre os funcionários de hospitais, estudantes e professores, aumento do numero de atendimentos de emergência a casos de diarréia e um grande consumo de drogas antidiarréicas. $\mathrm{O}$ agente etiológico e a associação com a agua de consumo somente foram determinados 2 semanas após o inicio do surto, quando foi emitida uma recomendação para fervura da água. (MAC KENZIE et al. 1994).

Entre 1995 e 1996, de acordo com LEVY et al 1998, foram relatados 22 surtos de doenças associados à água de consumo humano. Dois desses surtos foram causados pelo protozoário Giardia. um no Alaska, que afetou 10 pessoas e um grande surto em Nova lorque no qual 1449 pessoas foram atingidas. Nesse último surto, a água era de origem superficial e tinha sido filtrada e clorada. Observou-se uma relação doseresposta entre o consumo de água e doença. Foi também verificada uma elevação na 
turbidez das amostras de água tratada na planta, parâmetro utilizado para avaliação da eficiência do processo de filtração.

Dentre os 17 surtos relatados entre 1997 e 1998 ( BARWICK et al. 2000) 4 foram causados por Giardia e 2 foram causados pelo Cryptosporidium. Um dos surtos de giardiase ocorreu em Nova Iorque, atingiu 50 pessoas e esteve associado a um suprimento de água clorado e não filtrado. O outro surto teve lugar no Oregon, afetando 100 pessoas que consumiram água de um sistema não comunitário que utilizava água subterrânea não tratada misturada a uma fonte-clorada. Esses dois surtos ocorreram no mês de junho, durante o verão portanto. Outros dois surtos envolvendo a Giardia na Florida, atingiram um total de 7 pessoas que consumiram água subterrânea provavelmente contaminada após fortes chuvas

Os demais surtos foram causados pelo Cryptosporidium, um deles, no Novo México, associado ao consumo de água subterrânea clorada, e o segundo após contaminação por esgoto de vários poços utilizados por uma comunidade no Texas, quando 1400 pessoas adquiriram a infecção, das quais 23 foram hospitalizadas. 


\subsubsection{2 - Surtos de Giardiase e Criptosporidiose nos Estados Unidos associados ao Contato Recreacional}

Entre 1991 e 1992, oito estados relataram 11 surtos de gastroenterite associados ao contato recreacional, envolvendo 942 pessoas, das quais 9 teriam sido hospitalizadas. Em 6 desses surtos (55\%) os agentes etiológicos identificados foram os protozoários Giardia (4) e Cryptospordium (2). A ingestão acidental de água recreacional bruta foi responsável pela gastroenterite por Giardia em 3 dessas ocorrências, mas os três outros surtos estavam associados a piscinas comunitárias, cujas águas eram cloradas e filtradas, e nas quais não foram observados quaisquer problemas no tratamento. Em 5 desses casos não foi realizada a análise da água para os protozoários, e no último esses organismos não foram detectados, três meses após, na água de retro-lavagem dos filtros da piscina (MOORE et al. 1994).

Entre 1993 e 1994, nove estados americanos relataram 14 surtos de gastroenterite associados ao contato recreacional, envolvendo um total estimado de 1437 pessoas, das quais 14 foram hospitalizadas. Em $10(71,4 \%)$ dessas ocorrências, foram responsabilizados os protozoários Giardia (4) e Cryptosporidium (6). Em 5 dos surtos causados pelo Cryptosporidium, tratavam-se de piscinas cujas águas eram filtradas e cloradas, somente tendo sido detectado um problema no tratamento da àgua de uma dessas piscinas. A água foi analisada em 2 desses casos, tendo sido obtidos resultados negativos para o Cryptosporidium, mas essas análises foram realizadas somente duas semanas após o inicio dos surtos, e num dos casos a piscina já tinha sido submetida a uma hipercloração $O 5^{\circ}$ surto foi ocasionado pela utilização recreacional de um lago, e teve a duração superior a 4 semanas e os oocistos do protozoário foram detectados em amostras de água do lago coletadas cinco semanas após o início do surto. Os 4 surtos de giardiase tiveram como causa a ingestão acidental de água, de um lago (2), de um rio (1) e de uma piscina pública (1), este último tendo tido duração superior a 3 meses. Amostras de água dos lagos, coletadas após 2 e 4 semanas, respectivamente do inicio dos surtos, foram negativas para Giardia ( KRAMER et al. 1996).

De 1995 a 1996, foram relatados 22 surtos de gastroenterites, dos quais $6(27,3 \%)$ foram causados pelo (ryptosporidium e um (4,5\%) pela Giardia. Dois grandes surtos 
de criptosporidiose causaram a doença num total estimado de 8.449 pessoas, um deles tendo ocorrido após um provável acidente fecal numa piscina infantil, num parque aquático, e, o outro, também num parque aquático. Em ambos episódios, algumas amostras de fezes dos pacientes foram positivas para Giardia e Cryptosporidium. Dois outros surtos foram ocasionados pelo contato recreacional com piscinas, nos quais 24 e 22 pessoas foram atingidas, com uma e seis hospitalizações, respectivamente. Três pessoas contraíram criptospordiose após contato recreacional com águas de um lago possivelmente contaminado pelo carreamento de fezes de gado após fortes chuvas. Num outro caso semelhante (contato com águas contaminadas por fezes de gado), 14 pessoas foram afetadas. Uma piscina infantil foi a provável causa de gastroenterite para 77 pessoas, das quais 60 tiveram exames de fezes positivos para Giardia, 17 para o Cryptosporidium e 8 para ambos os parasitas (LEVY et al. 1998).

Nove $(50 \%)$ dos 18 surtos de gastroenterites relatados nos Estados Unidos entre 1997 e 1998 foram causados pelo Cryptosporidium. Em um deles oito pessoas contrairam a doença após nadarem em um lago num parque estadual, enquanto que os outros 8 estavam associados ao contato recreacional com água tratada. Após contato com uma fonte, cuja água era filtrada e clorada, e cujo propósito inicial era apenas decorativo, mas que era entretanto bastante utilizada por crianças, principalmente em dias quentes, 369 pessoas foram afetadas. Em todos os outros casos de surtos causados pelo contato recreacional com piscinas, envolvendo cerca de 90 pessoas, a origem provável da contaminação era acidente fecal ou a utilização da piscina por crianças com criptosporidiose (BARWICK et al.). 


\section{2 - Giardia e Cryptosporidium no Ambiente}

\section{As origens da Contaminação}

Num trabalho de revisão sobre a deteç̧ão de protozoários no ambiente, SMITH 1998 discute a importância da contaminação ambiental na transmissão desses organismos. Vários fatores, relacionados tanto ao parasita como ao ambiente, desempenhariam um papel no potencial para essa contaminação, incluindo número de hospedeiros infectados, infecciosidade das formas excretadas pelos indivíduos infectados, atividade humana (e não humana na transmissão zoonótica), hábitos culturais e nivel socio-econômico, distribuição geográfica, saneamento, proteção dos sistemas de abastecimento de água e das fontes de agua bruta utilizadas para captação e tratamento, clima e hidrogeologia da área. Para a Giardia e o Cryptosporidium vários desses fatores são relevantes, como a prevalência da Giardia intestinalis, (a infecção por protozoários mais comum em humanos), periodo prolongado de excreção e número de cistos infecciosos excretados nas fezes (até $1,4.10^{10}$ diariamente). O C. parvum apresenta essas mesmas caracteristicas e além dos humanos, vários animais podem ser infectados excretando igualmente elevadas quantidades de oocistos nas fezes. Ao contrário de outros parasitas, os cistos e oocistos são excretados já na forma infecciosa. O autor também relaciona as fontes de contaminação desses organismos para o ambiente e suas formas de disseminação. Juntamente com MEINHARDT et al 1996, SMITH 1998, cita algumas práticas utilizadas na agricultura como o uso de excrementos animais para fertilização das lavouras e a irrigação com águas residuárias brutas, que contribuem para a contaminação ambiental. Deve-se também incluir como fonte de contaminação agrícolas as fezes dos animais que podem ser carreadas, principalmente durante os periodos de fortes chuvas, e atingir os corpos hidricos. Dentre as atividades humanas, é fonte de contaminação o hábito relativamente comum das crianças de defecar nos quintais, enquanto que os trabalhadores agricolas também costumam utilizar as áreas próximas ao seu trabalho com esse objetivo. Essas práticas levariam a contaminação desses recursos hidricos bem como do solo. Os animais coprófagos, tais como porcos, cães, galinhas, gaivotas e moscas. seriam um fator de disseminação 
ambiental para os parasitas que possuem um hospedeiro animal, como no caso do $C$. parvum (Otto, Kort et al 1931, Sterling, Miranda et al 1987, Smith et al 1993, Gilles 1996 citados por SMITH 1998).

Os efluentes de estações de tratamento de esgotos são origem relevante da contaminação ambiental, dependendo do tamanho da comunidade atendida $e$ prevalência da infecção entre os seus habitantes. O lançamento desses efluentes em corpos d'água utilizados para captação pode contaminar esses recursos com cistos e oocistos dos protozoários

\subsection{1 - Efluentes Domésticos}

Vários autores analisaram esgotos brutos e tratados apos vários niveis e tipos de tratamento. GRIMASON et al 1993 avaliaram a ocorrência e remoção dos protozoários em 11 diferentes tipos de lagoas de estabilização no Quênia. Os oocistos de Cryptosporidium e os cistos de Giardia foram detectados, respectivamente, em 6 e 9 desses sistemas. As concentrações de oocistos nas amostras brutas foram de 12,5$72,97 / \mathrm{L}$ e nos vários efluentes das lagoas de 2,25-50/L. Para os cistos de Giardia foram determinadas concentrações de 212,5-6212,5/L nos afluentes brutos e de 3,125-230,7/L nos vários efluentes das lagoas. Quanto aos efluentes finais, não foram detectados oocistos de Cryptosporidium em nenhuma das 11 lagoas estudadas mas os cistos de Giardia foram observados consistentemente em uma dessas lagoas.

ROSE et al 1996 pesquisaram as concentrações de (ryptosporidium. durante um periodo de 12 meses em efluente bruto, apos tratamento secundário (lodo ativado) e após filtração em areia. Foram detectados oocistos em $67 \%, 42 \%$ e $42 \%$ das amostras, respectivamente, em concentrações médias de $15,1,4$ e $0,04 / \mathrm{L}$, as concentrações máximas sendo 120,11 e 0,13/L. Num estudo semelhante, CHAURET et al 1995, numa avaliação realizada em uma ETE (Estação de Tratamento de Esgotos de Otawa, no Canadá, verificaram densidades similares de Cryptosporidium, com médias de 17,3 oocistos/L ( 2 amostras) no efluente bruto e 0.56 oocistos/L ( 3 amostras) no efluente tratado por lodos ativados. Para a Giardia, esses valores foram de 103 cistos $/ \mathrm{L}$ e 0,73 cistos $/ \mathrm{L}$, respectivamente. 
Durante um periodo de 3 anos, ENRIQUEZ et al 1995 pesquisaram a presença de Giardia e Cryptosporidium em 130 amostras provenientes de 2 estações de tratamento de efluentes pelo processo de lodos ativados e de uma estação de reúso de água a partir do efluente secundário de uma dessas plantas. $\mathrm{Na}$ planta 1 , as concentraçôes mensais de cistos de Giardia em 40 litros de efluente secundário, variaram entre 2 a 26, com média geométrica de 8,3, enquanto que na planta 2 esses valores foram de 2 a 15 , com média geométrica de 6,6 cistos/40 L. Os oocistos de Cryptosporidium foram detectados com freqüência e em concentrações muito inferiores: um ou dois oocistos em 40 litros de efluente secundário na maior parte dos meses do ano. Esses autores não observaram uma distribuição sazonal das concentrações de qualquer um desses parasitas.

BUKHARI et al 1997 pesquisaram a presença dos protozoários em 7 estações de tratamento de esgoto na Inglaterra. Os oocistos de (ryptosporidium foram detectados em $0-63,6 \%$ dos afluentes, em densidades de $10-170$ oocistos/L, e em 15,4 a $46,6 \%$ dos efluentes, em densidades de 10-60 oocistos/L. Quanto aos cistos de Giardia. a positividade foi de 70-90,9\% nos afluentes, as concentrações variando de 10-13.600 cistos/L, enquanto que nos efluentes esses valores foram de $15,4-91,7 \%$ e 10-720/L.

Para avaliar a ocorrência dos protozoários, e eficácia do tratamento pela Estação de Tratamento de Água de Pittsburgh, na Pensilvânia, Estados Unidos, STATES et al 1997. monitoraram suas densidades, mensalmente, durante 2 anos no efluente tratado da ETE local e nas águas de retrolavagem de filtros da estação de tratamento. O monitoramento dos efluentes da ETE após tratamento secundário demonstrou a presença de Ciardia e cryptosporldium em $83 \%$ e $33 \%$ das amostras respectivamente, a maior porcentagem de amostras positıvas para Giardia refletindo provavelmente a eliminação crônica de cistos pelos portadores assintomáticos dessa infecção. Os processos de clarificação e filtração utilizados na estação de tratamento parecem ser plenamente efetivos para a eliminação dos cistos de Giardia, mas oocistos de Cryptosporidium podem passar para as águas tratadas, mesmo sem quaisquer falhas nos processos de tratamento. Nas aguas de retrolavagem dos filtros da estação de tratamento, $38 \%$ das amostras foram positivas para o Cryptosporidium (média geométrica : 328 oocistos/100L) e, para a (jiardia esses valores foram de $8 \%$ e 59 cistos/100L. Os autores estudaram igualmente a contribuição dos efluentes 
urbanos sanitários combinados (águas de carreamento de chuvas e degelo e o transbordamento de esgoto das ETEs). Assim, análises realizadas em 5 dessas amostras durante esse estudo revelaram elevadas concentrações dos protozoários (3.750-114.000 cistos/100L e 0-3.000 oocistos/100L).

GIBSON et al 1998a estudaram especificamente os efluentes sanitários urbanos combinados como fonte de contaminação de Giardia e Cryptosporidium. As análises foram realizadas num pequeno curso d'água na cidade de Pittsburgh, na Pensilvânia, Estados Unidos, durante a estação seca, e, comparativamente, nos efluentes sanitários urbanos combinados. Foram detectadas concentrações de 5-105 oocistos/100L de Cryptosporidium e de 13-6.579 cistos/100L de Giardia, no curso d'água, durante a seca. A análise dos protozoários, durante a estação chuvosa, nos efluentes sanitários urbanos combinados, revelou valores de 250-40.000 oocistos/100L e 9.000-283.000 cistos/L, demonstrando assim o alto potencial de contaminação desses efluentes.

A prevalência dos parasitas no Canadá foi estudada por WALLIS et al 1996, num amplo estudo no qual foram analisadas 1760 amostras, incluindo águas brutas, tratadas e esgotos. Os autores também avaliaram a viabilidade dos cistos de Giardia detectados e realizaram a biotipagem desses isolados através da determinação de suas isoenzimas e cariotipagem por eletroforese de campo pulsante. Os cistos de Giardia e oocistos de Cryptosporidium foram detectados em $73 \%$ e $6,1 \%$ das amostras de esgoto (total de 164 amostras). A maior parte das amostras continha concentrações de aproximadamente 1.000 cistos/L para a Giardia, variando entre 1 a 120 oocistos/L para o Cryptosporidium. Os estudos de biotipagem e cariotipagem revelaram que os organismos isolados eram genetica e bioquimicamente semelhantes àqueles isolados em outros locais.

Também no Canadá, PAYMENT et al. 2001 estudaram as concentrações de vários microrganismos indicadores e patogênicos, dentre eles os protozoários Giardia e Cryptosporidium, durante 6 meses, em amostras de afluentes e efluentes de uma grande ETE da região de Montreal. De acordo com os resultados, as concentrações de Giardia variaram pouco durante todo o periodo de estudo, com médias geométricas de 1.165 cistos/L no esgoto bruto e 285 cistos/L no efluente tratado. As concentrações detectadas de Cryptosporidium foram bem mais baixas 
(média geométrica de 6 oocistos/L no esgoto bruto e 4 oocistos/L no efluente tratado), com várias amostras apresentando resultados negativos.

Numa pesquisa de 3 anos em 6 estações de tratamento de esgoto na Escócia, ROBERTSON et al 2000 determinaram as concentrações de Giardia e Cryptosporidium, compararam métodos de detecção dos parasitas nessas amostras e avaliaram a eficiência de remoção das diferentes etapas de tratamento: $75 \%$ (21/28) das amostras de esgoto bruto foram positivas para o Cryptosporidim. em concentrações de 5 a 60 oocistos $/ \mathrm{L}$ (média $=21$ oocistos; mediana $=10$ oocistos) Maior número de amostras ( $96 \%$ ) foram positivas para a Giardia e as concentrações desse protozoário também foram mais elevadas (5-940 cistos $/ \mathrm{L}$, média $=284$ cistos, mediana $=265$ cistos). A metodologia mas eficiente foi aquela que utilizou a concentração de volumes relativamente baixos de amostra composta (1-2L) concentrada simplesmente através de centrifugação, em oposição à metodologia atraves da qual grandes volumes de amostra (cerca de 100L) eram filtrados em cartuchos de $1 \mu \mathrm{m}$ de porosidade nominal. A remoção dos parasitas era praticamente nula com a decantação primária somente, sendo necessária a associação do tratamento secundário, devendo-se ainda acrescentar que essa remoção é mais efetiva para os cistos de Giardia que para os oocistos de Cryptosporidium. De acordo com dados obtidos nesse estudo e em outros trabalhos semelhantes, o tratamento terciário (filtração) pode ser bastante efetivo para remoção de ambos protozoários

Numa pesquisa desenvolvida na região de Turim, na Itália, CARRARO et al 2001 analisaram efluentes de uma ETE bem como as águas do rio Pó, nos locais a montante e a jusante dos lançamentos da ETE. Os protozoários foram detectados em todas as amostras de efluentes, embora em baixas concentrações, em média 0,2 oocistos $/ \mathrm{L}$ e 1,4 cistos/ $\mathrm{L}$, enquanto que em algumas amostras de afluentes foram observadas densidades médias de 4,5 oocistos/L e 53,6 cistos/L. Nas amostras do rio Pó, todas as amostras foram igualmente positivas, não tendo sido verificadas diferenças nas concentrações médias detectadas a montante $(0,2$ oocistos $/ L ; 1,3$ cisto/L) e a jusante do lançamento da ETE $(0,17$ oocistos/L; 1 cisto/L). A partir desses resultados, os autores concluem que a ETE em questão não contribui significativamente para a contaminação do rio Pó pelos protozoários Giardia e cryptosporidium. 
No Brasil, dois estudos realizados até o momento demonstraram a presença de concentrações elevadas de Cryptosporidum sp em efluentes domésticos e que portanto esses efluentes podem representar uma importante fonte de disseminação do parasita no meio aquático e na comunidade. DIAS JÚNIOR 1999 analisando a presença dos protozoários em amostras de águas superficiais e esgotos na cidade de Araras, no estado de São Paulo, detectou cistos de Giardia e oocistos de Cryptosporidium em concentrações de $2.227 / \mathrm{L}$ e $472 / \mathrm{L}$, respectivamente. FARIAS 2000 pesquisou Cryptosporidium spp em águas de esgoto da cidade de São Paulo, observando positividade de $100 \%$ em 24 amostras analisadas, e concentrações máximas de 1.200 oocistos/L nas amostras de esgoto e de 1.400 oocistos/L nas águas de um córrego receptor que também foram analisadas. 


\subsection{2 - Águas Superficiais e Subterrâneas Brutas}

Várias pesquisas realizadas em diferentes paises avaliaram as concentrações de Giardia e Cryptosporidium nos diferentes ambientes aquáticos, incluindo águas superficiais e subterrâneas brutas, estudando a ocorrência dos parasitas e características tais como sazonalidade, formas de ocupação do solo e também a correlação com outros parâmetros físico-quimicos e microbiológicos dessas águas.

Num estudo realizado no Canadá, WALLIS et al 1996, detectaram Giardia e Cryptosporidium em $21 \%$ e $4,5 \%$, respectivamente de 1.173 amostras de águas superficiais brutas analisadas. Embora os cistos e oocistos estivessem presentes nessas amostras durante todo o ano, sua ocorrência era mais freqüente ao fim do inverno, inicio da primavera e outono.

Também no Canadá, na provincia de British Columbia, ONG et al 1996 avaliaram padrões e origens da contaminação por Giardia e Cryptosporidium nas águas superficiais captadas para tratamento em duas bacias adjacentes. As análises foram realizadas em 249 amostras de águas brutas coletadas em diferentes pontos dos cursos de agua e também em amostras de fezes de animais, uma vez que a atividade de criação de gado era bastante comum nessas comunidades. Não foram detectados cistos de Giardia nos lagos que dão origem às águas dessas bacias, mas cerca de $100 \%$ das amostras coletadas em outros pontos das duas bacias foram positivas para esse protozoário. Concentrações significativamente mais elevadas $(p<0,05)$ de cistos foram detectadas no ponto de captação de uma das bacias na qual o gado tinha livre acesso aos corpos de agua ( 7 a 2.215 cistos/100L) em comparação às amostras do ponto de captação da outra bacia, na qual o acesso do gado era mais restrito ( 2 a 114 cistos/100L) A análise de amostras coletadas a montante e a jusante de uma fazenda demonstrou níveis significativamente mais elevados $(p<0,05)$ a jusante $(0,6$ a 42.9 cistos/ $100 \mathrm{~L} ; 1,4$ a 300 oocistos $/ 100 \mathrm{~L})$ que a montante $(0,5$ a 34,4 cistos $/ 100 \mathrm{~L}$; 0,5 a 34,4 oocistos/100L) tanto para Giardia como para (ryptosporidium. 
Para avaliar a ocorrência dos protozoários, sua origem e eficácia do tratamento pela Estação de Tratamento de Água de Pittsburgh, na Pensilvânia, Estados Unidos, STATES et al 1997, monitoraram suas densidades, mensalmente, durante 2 anos no rio Allegheny, cujas águas são utilizadas como suprimento de água bruta. Para comparação, um rio próximo, o Youghiogheny, também foi estudado. No rio Allegheny $63 \%$ das amostras analisadas foram positivas para Giardia e Cryptosporidium, em concentrações (média geométrica) de 34 cistos/100L e 31 oocistos/100L. Para o rio Youghiogheny, esses valores foram de $54 \%$ e $63 \%$, com médias geométricas de 118 cistos/100L e 58 oocistos/100L

HO e TAM 1998 monitoraram durante 13 meses consecutivos, dois importantes rios de Hong Kong (Shing Mum e Lam Tsuen) quanto à presença de Giardia e Cryptosporidium. Os oocistos de Cryptosporidium raramente foram detectados nos dois rios, e as concentrações de Giardia eram baixas, em torno de 10 cistos/L nos pontos de amostragem situados em áreas pouco povoadas. Entretanto, nos locais de coleta próximos à descarga de efluentes domésticos tratados e pequenas localidades servidas por ETEs e fossas sépticas, foram detectadas níveis elevados de Giardia, atingindo um máximo de 468 cistos/L. Como as concentrações de Giardia pareciam estar relacionadas ao tipo de tratamento utilizado nas ETEs, os autores sugerem que esse protozoário seja utilizado como indicador da eficácia de tratamento dos efluentes domésticos, e também da qualidade das águas dos rios locais.

A distribuição dos parasitas nos suprimentos de água na Alemanha foi estudada por KARANIS et al 1998. Os autores também avaliaram a eficiência de remoção de alguns processos em 6 plantas de tratamento de água do país. Giardia, Cryptosporidium, ou ambos foram detectados em $76,2 \%$ das águas superficiais brutas analisadas, em concentrações médias de 88,2 cistos/100L e 116 oocistos/100L Nas etapas intermediárias do tratamento, a positividade foi de $33,3 \%(50 / 150)$ e os protozoarios foram encontrados em praticamente todas as amostras de águas de retrolavagem dos filtros. 
Num trabalho realizado no rio Delaware, na Pensilvânia, Estados Unidos, ATHERHOLT et al 1998, avaliaram as concentrações dos parasitas durante o ano de 1996. O objetivo dos autores era estudar a relação entre as densidades de Glardia e Cryptosporidium e outros parâmetros de qualidade da água, e, também as condições meteorológicas. Foram detectadas concentrações médias de 2,5 cistos de Giardia (máximo:40 cistos) e de 0,5 oocistos de Cryptosporidium (máximo: 14 oocistos). Esses resultados são expressos em 5L de "volume equivalente", o termo "volume equivalente" correspondendo à fração do volume de amostra de água coletado, filtrado e processado, que foi submetida à microscopia. Observou-se uma correlação positiva entre as concentrações dos parasitas e outros treze parâmetros. Além disso, verificou-se que essas concentrações aumentavam com a época das chuvas.

As águas naturais da Nova Zelândia foram avaliadas quanto à presença desses protozoários numa pesquisa realizada por IONAS et al 1998: nas amostras, coletadas e analisadas pelo menos duas vezes em todo o território foram detectados cistos de Giardia e oocistos de cryptosporidium em $22,5 \%$ e $13,0 \%$, respectivamente. As porcentagens mais elevadas de positividade foram observadas nas areas de criação intensiva de gado.

SOLO-GABRIELE et al 1998 estudaram a ocorrência dos parasitas nos suprimentos de água da cidade de São Pedro, Honduras. Em três amostras de águas superficiais, as concentrações de Cryptosporidium variaram entre 58 a 260 oocistos/100L, enquanto que a Giardia foi detectada em densidades de 380 a 2.100 cistos/100L. Nas amostras de águas subterrâneas. diferentemente das águas superficiais, foram detectadas concentrações mais elevadas de Cryptosporidium (26 oocistos/100L) do que a Giardia $(6 / 100 \mathrm{~L})$, e os autores sugerem que nos aqüiferos subterrâneos os suprimentos de agua estão mais efetivamente protegidos da contaminação por Giardia, em virtude da maior dimensão dos cistos desse organismo. Ainda segundo esses autores, as concentrações observadas de Cryptosporidium são similares àquelas observadas na América do Norte, mas as densidades de Giardia são consideradas elevadas, devendo ser feitos esforços para proteger-se as águas brutas das fontes de contaminação 
As concentrações de Giardia e Cryptosporidium nas águas subterrâneas dos Estados Unidos foram avaliadas por HANCOCK et al 1998. Foram analisadas 463 amostras coletadas em 199 áreas, incluindo poços verticais, fontes, galerias de infiltração e poços horizontais. De acordo com os dados obtidos, $12 \%$ dos locais foram positivos para Giardia, Cryptosporidium ou ambos. Os oocistos de Cryptosporidium foram detectados em $5 \%$ dos poços verticais, $20 \%$ das fontes, $50 \%$ das galerias de infiltração e em $45 \%$ dos poços verticais, e, para Giardia esses valores foram de $1 \%, 14 \%, 25 \%$ e $36 \%$, respectivamente. As concentrações de Giardia em 23 amostras positivas variaram de $1-112$ cistos/100L, e as de Cryptosporidium foram de 0,2-45 oocistos/100L (62 amostras positivas).

MAGARA et al. 1999, numa pesquisa nacional organizada pelo Ministério da Saúde, no Japão, avaliaram a ocorrência de Giardia e Cryptosporidium em águas brutas captadas para tratamento. De 277 amostras provenientes de 94 corpos d'água, 9\% foram positivas para Giardia e 3\% para o Cryptosporidium.

A ocorrência dos protozoários no rio Kau-Ping, cujas águas são importante fonte de captação em Taiwan foi estudada por HSU et al. 1999. Das amostras coletadas, num total de 13 , em diferentes pontos do rio, $92 \%$ e $61 \%$ foram positivas para Giardia e Cryptosporidium respectivamente, com densidades de 1.956 cistos/L e 4.776 oocistos/L.

SKERRET e HOLLAND 2000 avaliaram a ocorrência de oocistos de Cryptosporidium na região da grande Dublin, na Irlanda, em amostras de águas brutas. As amostragens foram realizadas semanalmente, durante cerca de 5 meses, em 4 corpos d'água utilizados para captação e em um rio, num ponto localizado a jusante de uma ETE. De um total de 69 amostras analisadas, 28 (40,6\%) foram positivas para oocistos de Cryptosporidium, com densidades variáveis nos diferentes locais, entre 0 e 6,0 oocistos/L. De acordo com os autores, os corpos d'água mais contaminados foram aqueles sujeitos a drenagem pelas águas da chuva. 
ROUQUET et al. 2001 estudaram a origem e ocorrencia de cistos de Giardia e oocistos de Cryptosporidium nas bacias dos rios Sena e Marne, na região de Paris, França. Os autores observaram concentrações de Cryptosporidium bastante inferiores às de Giardia, com médias de 218 oocistos/100L e 216 oocistos/L, e 928 cistos/100L e 824 cistos/L, no Sena e no Marne, respectivamente.

No Brasil, na cidade de Araras, no estado de São Paulo, foram analisadas 12 amostras de águas superficiais, incluindo-se pontos de captação de água para a cidade e pontos sob a influência de lançamento de efluentes domésticos. A Giardia e o Cryptosporidium foram detectados, respectivamente, em $8(66,7 \%)$ e $9(64,4 \%)$ das amostras (DIAS JÚNIOR, 1999).

FRANCO et al. 2001 analisaram esses protozoários na região de Campinas, no estado de São Paulo: Giardia e Cryptosporidim foram detectados em todas as amostras coletadas no Rio Atibaia, em concentraçōes máximas de 95,0 cistos/0,5L e 60,8 oocistos $/ 0,5 \mathrm{~L}$. 


\subsection{3 - Águas Tratadas}

LECHEV ALIER et al 1997 avaliaram vários parâmetros de qualidade de água em 6 reservatórios de água tratada, em New Jersey, nos Estados Unidos, incluindo os parasitas Giardia e Cryptosporidium. Todos os reservatórios eram alimentados com água tratada através de processos convencionais, proveniente de fontes superficiais, exceto em um deles, cuja água, de excelente qualidade, era apenas clorada. As águas eram novamente cloradas antes de passarem aos sistemas de distribuição. Durante 12 meses, foram coletadas 10 amostras de entrada (afluente) e saida (efluente) dos reservatórios, totalizando 120 amostras, 60 de afluentes e 60 de efluentes. De acordo com os resultados obtidos, foram observadas densidades mais elevadas de ambos protozoários nas amostras efluentes ( 9 amostras positivas, média geométrica $=6,1$ cistos de Giardia/100L e 7 amostras positivas, média geométrica $=8,1$ oocistos de Cryptosporidium/100L) que na água alimentada aos reservatórios (8 amostras positivas, média geométrica $=1,9$ cistos $/ 100 \mathrm{~L}, 3$ amostras positivas, média geométrica $=1,2$ oocistos $/ 100 \mathrm{~L}$ ). De acordo com testes estatísticos não-paramétricos, essas diferenças são significativas para as concentrações de Cryptosporidium. mas não para as de Giardia $(\mathrm{p}<0,05)$.

No estudo já citado, realizado por WALLIS et al 1996 no Canadá, foram analisadas 423 amostras de águas tratadas. A maior parte dessas amostras procediam de comunidades que tratavam a água por cloração apenas. Giardia e Cryptosporidium foram detectados em $18.2 \%$ e $3.5 \%$ das amostras, respectivamente. Tambem foi possivel determinar as concentrações de Giardia durante surtos da doença, em algumas comunidades, observando-se que densidades de 3 a 5 cistos/100L de água tratada estavam normalmente associados a elevados niveis de giardiase.

Num estudo realizado na Alemanha, KARANIS et al 1998 detectaram Giardia em $14,9 \%$ das amostras de água de consumo humano, em densidades máximas de 16,8 cistos/100L, e Cryptosporidium em $29,8 \%$ dessas amostras, em densidades máximas de 20,8 oocistos/100L. Os autores concluem que os processos de tratamento devem ser otımizados para a eliminação dos parasitas e que mesmo sem 
quaisquer problemas aparentes nesses procedimentos Giardia e Cryptosporidium podem ultrapassar as múltiplas barreiras e contaminar a água tratada.

MULLER 1999 estudou a ocorrência e concentrações de Cryptosporidium em 48 amostras de águas superficiais e tratadas coletadas em duas Estações de Tratamento de Água da cidade de São Paulo, mensalmente, durante o periodo de um ano. Foram detectados oocistos do protozoário em $75 \%$ das amostras de águas brutas e $12.5 \%$ das amostras de águas tratadas, utilizando-se a técnica de concentração de floculação com carbonato de cálcio, enquanto que essas porcentagens foram de 73,91\% e $33,33 \%$, respectivamente ao empregar-se a técnica de concentração com membrana filtrante. Foram observadas densidades de 0 a 236 oocistos/L nas águas brutas e de 0 a 1,2 oocistos/L nas águas tratadas. A autora ressalta a importância do monitoramento do protozoário em águas brutas captadas para tratamento, tendo em conta as elevadas porcentagens de detecção do parasita nas águas tratadas.

RÉ 1999 avaliou a ocorrência dos protozoários Cryptosporidium sp e Giardia lamblia em aguas de consumo humano, no municipio de Araras, estado de São Paulo. Em 5 amostras de águas tratadas, provenientes da rede pública de abastecimento, foi detectada a presença de cistos de Giardia lamblia em 2 amostras (16.66\%), não tendo sido observada a ocorrência de Cryptosporidium sp e todas essas águas obedeciam aos padrões de potabilidade vigentes. Quanto a 7 amostras de água de poço avaliadas, 5 não atenderam aos padrões de potabilidade, porém todas foram negativas quanto à presença dos protozoários. 


\section{2 - LEGISLAÇÃO}

\section{1 - A legislação Americana}

A agência ambiental americana (USEPA) tem a autoridade para promulgar padrões sanitários para a qualidade da água de consumo humano conferida através de um ato legislativo do congresso americano (SDWA - "Safe Drinking Water Act). Essa mesma legislação permite que a agência estabeleça niveis máximos ideais para contaminantes potenciais da água de consumo humano que possam oferecer riscos à saúde. Trata-se do chamado "maximum contaminant level goal", ou MCLG, concentrações do contaminante que, com certa margem de segurança, não apresentariam efeitos conhecidos ou prováveis sobre a saúde de seres humanos. Não se trata de um limite legalmente obrigatório, e a agência deve, simultaneamente ao estabelecimento do MCLG, determinar para esse contaminante um nivel máximo permitido - MCL - "maximum contaminat level", ou, alternativamente, a utilização de uma técnica de tratamento da água efetiva para a redução ou remoção do contaminante, caso o estabelecimento do MCL não seja viável do ponto de vista técnico ou econômico (USEPA 2000).

Considerando a importância dos protozoários nas doenças de veiculação hídrica, já em 1989, foram estabelecidos MCLG de zero para Giardia lamblia, vírus e Legionella, atraves da "Surface Water Treatment Rule" - SWTR. Ainda segundo essa lei, todos os sistemas produtores de água que utilizassem águas superficiais ou subterrâneas sob a influência de águas superficiais deveriam adotar procedimentos para evitar a presença desses contaminantes na água. Dentre esses procedimentos incluiam-se a manutenção de um residual de desinfetante no sistema de distribuição, remoção e/ou inativação de 3 logs $(99,9 \%)$ de Giardia ou 4 logs $(99,99 \%)$ de vírus, limites para a turbidez da água e padrões de desempenho para os filtros (USEPA 1998). O objetivo era reduzir a transmissão de doenças de veiculação hídrica a níveis inferiores a um risco anual de $10^{-4}$ (SMITH e ROSE 1998). Uma importante deficiência da SWTR é que ela não determinou procedimentos de controle para o Cryptosporidium. 
Em 1996, a agência instituiu um regulamento para monitoramento e coleta de dados, a "Information Collection Rule" - ICR (USEPA 1996). Através da ICR, todos os sistemas fornecedores de água a mais de 100.00 pessoas, que utilizassem águas superficiais deveriam monitorar suas fontes de captação quanto à presença de cistos de Giardia, oocistos de Cryptosporidium e virus cultiváveis durante 18 meses. Caso os resultados fossem positivos para qualquer um dos protozoários, em concentrações iguais ou superiores a $1.000 / 100 \mathrm{~L}$ ou para vírus cultiváveis, em concentrações iguais ou superiores a $100 / 100 \mathrm{~L}$, era igualmente necessário o monitoramento da água tratada (ALLEN et al. 2000). Os objetivos dessa regulamentação eram avaliar as concentrações desses patogênicos nas águas brutas utilizadas para captação, e tambem coletar informações sobre os processos de tratamento utilizados pelos produtores de água para controle desses organismos. Essas informações seriam utilizadas como subsidio para estabelecimento de novas regulamentaçôes relativas não só a esses contaminantes microbianos mas também quanto aos chamados "Disinfection Byproducts" - DBPs, entretanto, diferentes problemas causaram atrasos na promulgação e real entrada em vigor desta lei e, em conseqüência, a agência teve que utilizar outras fontes de informação para fundamentar as novas regulamentações (USEPA 1998).

Em 1998, foi promulgada pela USEPA a "Interim Enhanced Surface Water Treatment Rule" - IESWTR (USEPA 1998a), que estabeleceu um MCLG de zero para (ryptosporidium em aguas de consumo humano. A lei estabelece igualmente que os sistemas que utilizam águas superficiais para abastecimento de uma população superior a 10.000 pessoas devem utilizar processos de filtração capazes de remover 2 logs de Cryptosporidium. A regulamentação determina igualmente uma série de requisitos relativos à turbidez da água, niveis de trihalometanos, exigência de realização de levantamentos sanitários para sistemas públicos de abastecimento que utilizem águas superficiais ou subterrâneas sob a influência de águas superficiais e providèncias relativas à proteção de novos reservatórios de água. A SWTR de 1996 permanece em vigor para todos os produtores de água, sendo válida a IESWTR quando aplicável. 


\section{2 - A legislação Inglesa}

No Reino Unido, uma nova legislação promulgada em junho de 1999, e em vigor desde $1^{\circ}$ de outubro do mesmo ano, é a única a estabelecer limites máximos para o Cryptosporidium. A "Water Supply (Water Quality) (Amendment) Regulations 1999, estabelece que determinados sistemas produtores de água, selecionados com base numa avaliação qualitativa do risco da presença de oocistos na água, devem monitorar diariamente a presença desse protozoário na água tratada fornecida à população. Para esse objetivo, a água deve ser coletada continuamente, num fluxo de $40 \mathrm{~L} / \mathrm{h}$, permitindo-se um intervalo inferior a 1 hora para a troca do dispositivo utilizado para a coleta, o que resulta em volumes de pelo menos $920 \mathrm{~L}$ coletados diariamente. $\mathrm{O}$ número de oocistos de Cryptosporidium presentes nessas amostras deve ser de no máximo 10/100L. Esse monitoramento deve ser feito em um ponto da saida da estação de tratamento, com metodologia e em laboratórios aprovados pela Secretaria de Estado que estabeleceu a lei. Se forem detectadas concentrações superiores, a empresa estará sujeita a penalidades (HSMO 1999).

Para FAIRLEY 1999, as autoridades inglesas adotaram essas medidas porque, de acordo com uma decisão judicial, evidências epidemiológicas não são suficientes para responsabilizar um sistema produtor de água pela ocorrência de um surto da doença Embora se admita que o monitoramento não é uma medida preventiva efetiva, acredita-se que a ameaça de processo e de multas irá fazer com que as empresas produtoras utilizem tratamentos mais eficientes para assegurar os niveis requeridos do parasita. Ainda segundo esse autor, a relação custo-beneficio não justifica essas medidas. Além disso, os métodos de análise atualmente disponiveis, que não determinam a viabilidade dos oocistos, não só limitam a utilização desses resultados em Saúde Pública, como também restringem o desenvolvimento de novos métodos de tratamento da água baseados na inativação dos oocistos, uma vez que apenas inativados eles ainda serão detectados, o que irá constituir em infração da lei. 


\section{3 - A legislação Brasileira}

No Brasil, a legislação federal que dispõe sobre a qualidade da água para consumo humano, recentemente revisada, é portaria 1469, do Ministério da Saúde, de 29.12. 2.000. Similarmente à legislação americana, não são estabelecidos níveis máximos para Giardia e Cryptosporidium, recomendando-se entretanto a pesquisa de organismos patogênicos, com o objetivo de atingir como meta, um padrão de ausência desses protozoários e de enterovírus. Determina igualmente, para a garantia da qualidade microbiológica da água, em complementação às exigências relativas aos indicadores microbiológicos, padrões de turbidez, de acordo com as técnicas de tratamento utilizadas. Os valores máximos permitidos são de 1,0 UT (unidades de turbidez) em 95\% das amostras de águas subterrâneas tratadas por desinfecção, 1,0 UT para água tratada através de filtração rápida e 2,0 UT para 95\% das amostras de águas tratadas através de filtração lenta. A portaria 1469 recomenda que para assegurar a adequada eficiência de remoção de enterovírus, cistos de Giardia e oocistos de Cryptosporidium, se estabeleça como meta, para a filtração rápida, a obtenção de efluente filtrado com valores de turbidez inferiores a 0,5 UT em 95\% dos dados mensais (MINISTÉRIO DA SAÚDE 2000). 


\section{4 - Legislação de Outros Países}

A atual legislação européia ("Drinking Water Directive") requer que a água destinada ao consumo humano não deve conter organismos patogênicos, nem parasitas ou algas. Essa diretiva, atualmente em revisão, reconhecendo a impossibilidade de estabelecer-se um padrão zero, irá requerer de maneira geral que "a água destinada ao consumo humano não contenha microrganismos patogênicos e parasitas em números que constituam risco potencial à saúde". Não será proposto um padrão numérico para Giardia ou Cryptosporidium (SMITH e ROSE 1998).

Nem Austrália ou Canadá recomendam qualquer tipo de padrão para os protozoários em águas, baseando-se no fato que os métodos disponiveis não são confiáveis, nem determinam a infeçciosidade dos organismos detectados (FAIRLEY et al 1999). 


\section{3 - OBJETIVOS}

O presente trabalho tem como objetivos:

- Realizar, apresentar e discutir os resultados das análises de Giardia e Cryptosporidium do Projeto "Rede de Monitoramento da Qualidade de Águas Interiores do Estado de São Paulo" da CETESB à luz da legislação brasileira e internacional;

- Discutir a importância desses resultados para a Saúde Pública levando-se em conta as limitações da metodologia atualmente disponivel;

- Discutir a importância da implementação de um rigoroso programa de Controle de Qualidade Analítica nos laboratorios que realizam as análises desses protozoários ;

- Avaliar a relação entre as concentrações dos indicadores bacterianos de contaminação fecal, coliformes fecais, estreptococos fecais e Clostridium perfringens e a ocorrência de Giardia e Cryptosporidium nas amostras analisadas. 


\section{4-MATERIAIS E MÉTODOS}

\section{1 - Amostragem}

\subsection{1 - Locais e Periodicidade da Coleta}

A coleta das amostras foi realizada nos locais e datas programados no projeto da CETESB "Rede de Monitoramento da Qualidade das Águas Interiores do Estado de São Paulo", que foi criado em 1974, de acordo com a lei estadual $N^{\circ} 118 / 73$. Esse projeto tem por principal objetivo avaliar a qualidade das águas de rios e reservatórios do Estado utilizados, dentre outros usos para abastecimento público, realizar o levantamento de áreas prioritárias para controle da poluição, dar subsidio técnico para elaboração dos Relatórios de Situação dos Recursos Hídricos realizados pelos Comitês de Bacias Hidrográficas e identificar trechos de maior degradação nos quais fosse requerida a ação preventiva e controle da CETESB, através da construção de ETEs (estações de tratamento de esgotos) pelos municipios ou adequação de lançamentos industriais (CETESB 1999).

$\mathrm{Na}$ época da realização desse trabalho eram monitorados 135 pontos através da análise de 43 parâmetros físicos, químicos e biológicos da qualidade da água, e destes 28 correspondiam a pontos de captação de água para abastecimento público, nos quais foram realizados, bimestralmente, de janeiro de 1999 a setembro de 2000, a determinação das concentrações dos protozoários Giardia sp e Cryptosporidium sp e dos indicadores bacterianos de contaminação fecal, estreptococos fecais e Clostridium perfringens, alem dos coliformes fecais, que fazem parte dos parâmetros biológicos analisados rotineiramente em todos os pontos da Rede. A partir de outubro de 2000, foi adotada outra metodologia de análise dos parasitas, e tais resultados não serão considerados nesse trabalho.

A Lei Estadual No 7663/91 que instituiu a Política Estadual de Recursos Hídricos e o Sistema Integrado de Gerenciamento de Recursos Hídricos, dividiu o Estado de São Paulo em 22 Unidades de Gerenciamento de Recursos Hidricos - UGRHIs, a avaliação da qualidade das aguas estando estruturada em função dessa divisão (Figura 1).

Os pontos de captação avaliados na Rede de Monitoramento de Qualidade das Águas Interiores situam-se nas UGRHIs 02,05, 06, 07, 09, 10, 15, 1721 e 22. 


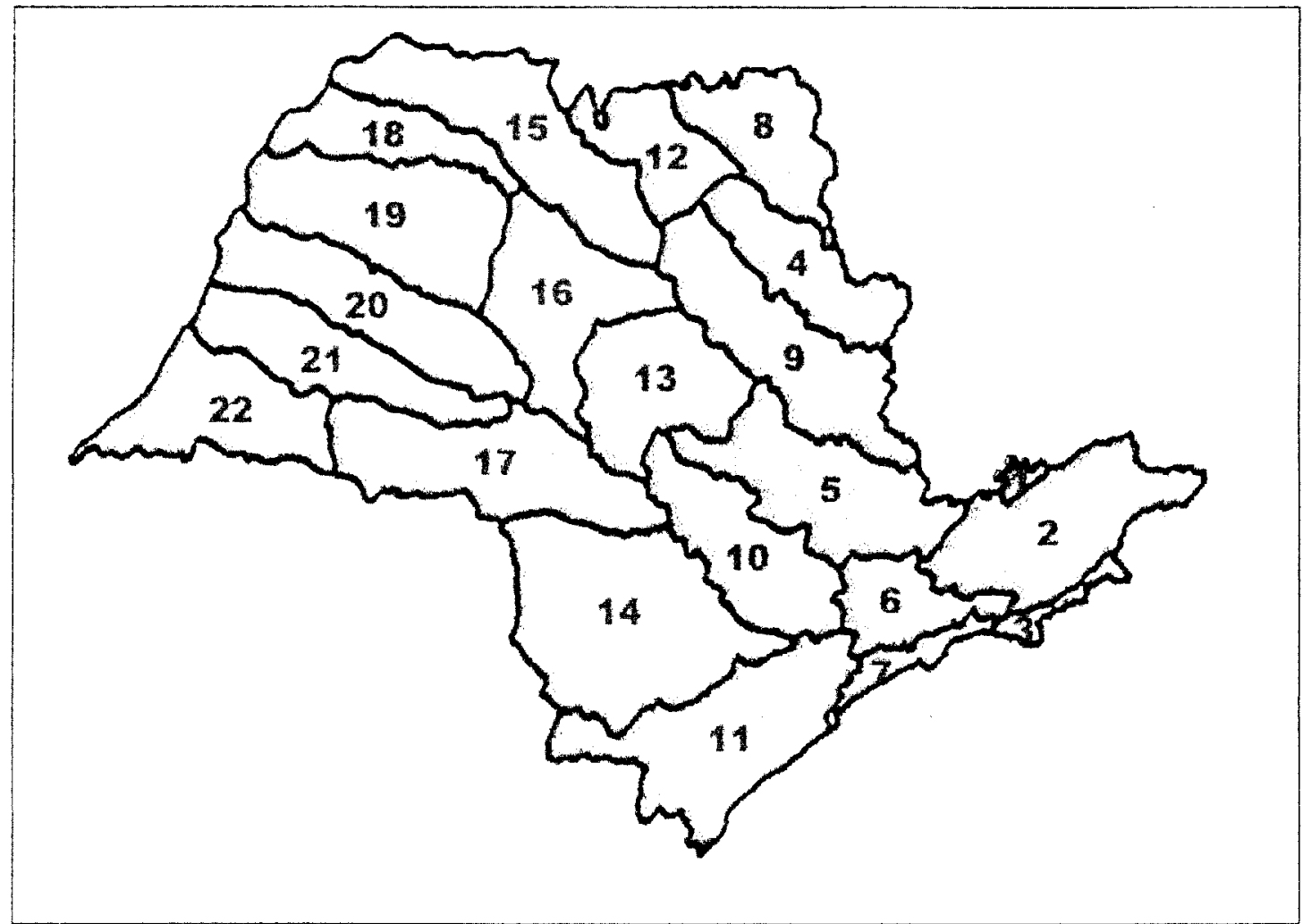

Figura 1 - Unidades de Gerenciamento de Recursos Hídricos (UGRHI) do Estado de São Paulo

Fonte: Secretaria de Recursos Hídricos do Estado de São Paulo

\subsubsection{1 - UGRHI 02 - Paraíba do Sul}

Esta Unidade engloba uma área de $14.396 \mathrm{~km}^{2}$, está situada ao leste do Estado, sendo composta por 34 municípios.

Os constituintes principais dessa bacia são os rios Paraibuna e Paraitinga, formadores do rio Paraíba do Sul e rios Paraté, Jaguari e Una.

A utilização do solo inclui principalmente a pecuária extensiva e culturas de milho e arroz. Existem grandes áreas de reflorestamento e mata tropical em uma pequena porção desta UGRHI

Os principais usos da água são abastecimento público e industrial, afastamento de efluentes domésticos e industriais e irrigação de plantações. 
Dentre as atividades industriais mais relevantes incluem-se a produção de papel e celulose, automóveis, alimentos, laticinios, produtos quimicos e petroquímicos e refinarias de petróleo.

São atualmente monitorados três pontos de captação para abastecimento público: dois pontos situados no rio Paraiba, que abastecem os municipios de Jacarei e Tremembe, o terceiro estando localizado no reservatório do Jaguari, abastecendo o municipio de Santa Isabel. Em 1999 foi captada uma vazão média anual de $0,037 \mathrm{~m}^{3} / \mathrm{s}$ para atendimento ao municipio de Tremembé e $0,471 \mathrm{~m}^{3} / \mathrm{s}$ para o municipio de Jacareí. Com relação ao manancial do Jaguari, foi captada uma vazão média de $0,061 \mathrm{~m}^{3} / \mathrm{s}$ para Santa Isabel (CETESB 1999).

No ponto localizado no reservatório do Jaguari e num dos pontos do rio Paraíba do Sul, junto à captação da SABESP, as amostragens foram realizadas em janeiro, abril, junho, agosto, outubro e dezembro de 1999, e em fevereiro, abril, junho e agosto de 2000. No terceiro ponto, rio Paraiba do Sul, junto à captação do municipio de Jacarei, o monitoramento teve início em outubro de 1999 prosseguindo até setembro de 2000

O mapa dessa Bacia bem como os pontos de captação analisados pode ser observado na Figura 2.

\subsubsection{2 - UGRHI 05 - Piracicaba, Capivari, Jundiaí}

Esta UGRHI possui uma area de $14.205 \mathrm{~km}^{2}$, sendo composta por 57 municipios. Devido a certas caracteristicas dessa Unidade. o monitoramento e avaliação da qualidade das aguas pela CETESB e realizado de acordo com suas bacias hidrográficas. 


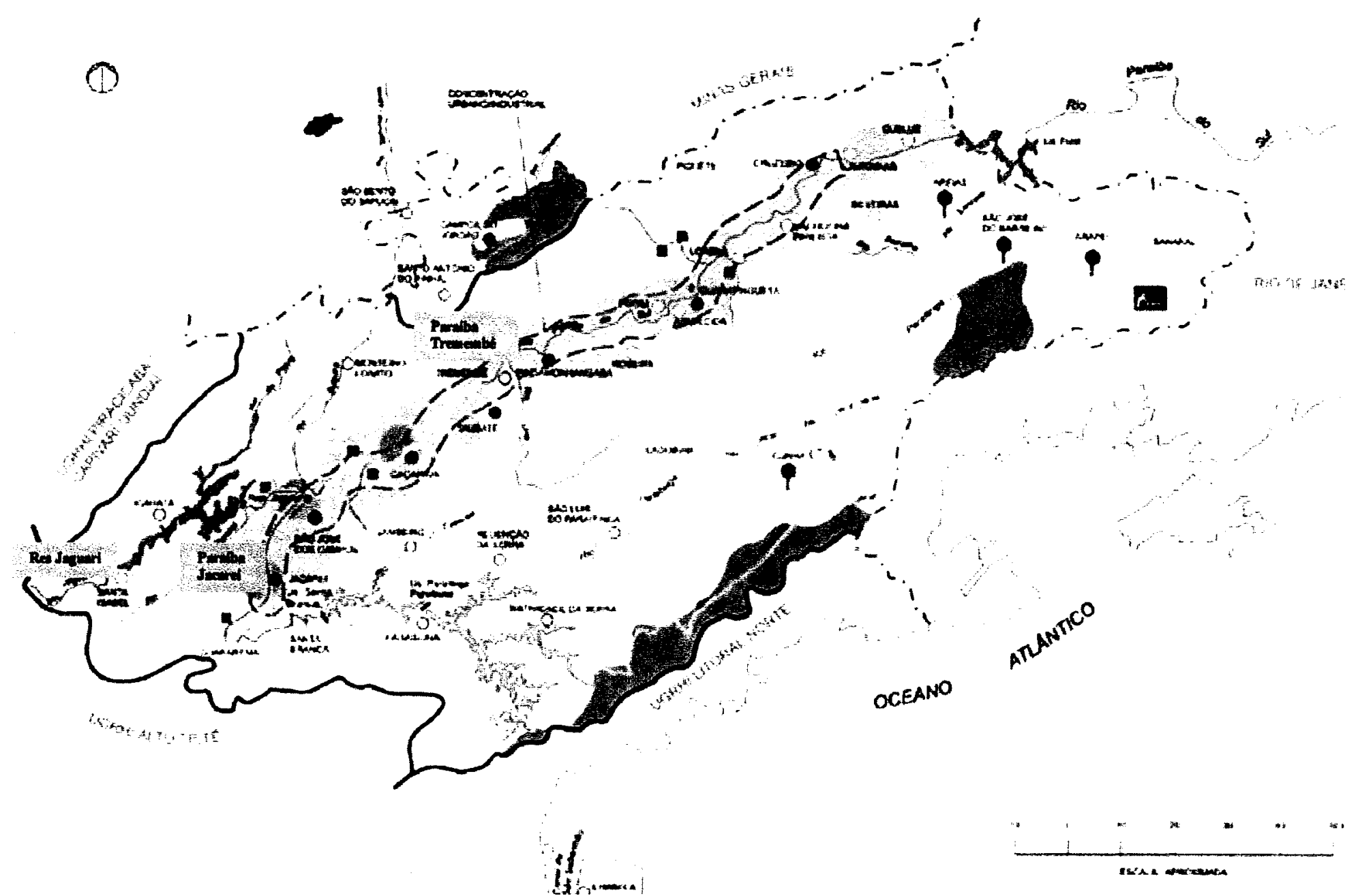

Figura 2 -Unidade de Gerenciamento de Recursos Hídricos 02 - Paraíba do Sul

Fonte: Secretaria do Meio Ambiente do Estado de São Paulo 


\section{Bacia do rio Capivari}

Esta bacia possui uma área de drenagem de $1.655 \mathrm{~km}^{2}$, tendo como constituintes principais os rios Capivari e Capivari-Mirim, da nascente até a foz, na margem direita do rio Tietê, com $180 \mathrm{~km}$ de extensão. Um dos principais usos do solo é para a cultura de cana de açúcar, seguindo-se pecuária, culturas de milho, café, feijão, reflorestamento, produtos hortifrutigranjeiros, ocupação urbana e industrial. Dentre os usos da água incluem-se o abastecimento público e industrial, o afastamento de efluentes domésticos e industriais e a irrigação de plantações. A atividade industrial corresponde essencialmente a indústrias de açúcar e álcool, quimicas, metalúrgicas, têxteis, alimentícias e curtumes.

$\mathrm{O}$ rio Capivari foi monitorado em seu trecho inicial, que é utilizado como manancial de abastecimento público de parte do municipio de Campinas, tendo sido captados $0,165 \mathrm{~m}^{3} / \mathrm{s}$ em 1999 (CETESB 1999). As coletas nesse ponto foram realizadas em janeiro, março, maio, julho, setembro e novembro de 1999 e em janeiro, março, maio e setembro de 2000.

\section{Bacia do rio Jundiaí}

A área de drenagem da Bacia do rio Jundiaí é de $1.150 \mathrm{~km}^{2}$ e têm como constituintes principais os rios Jundiai, Jundiaí-Mirim e Piraí. A nascente do rio Jundiaí está localizada na Serra de Pedra Vermelha, em Mairiporã, e ele deságua na margem direita do rio Tietê, no reservatório da Usina de Porto Góes, em Salto.

Quanto aos usos do solo, cerca de metade da área é ocupada por pastagens naturais e cultivadas, parte para reflorestamento e uma pequena porcentagem contém matas e capoeiras. A atividade agrícola predominante refere-se a produtos hortifrutigranjeiros. A área apresenta atividade urbana e industrial acentuada.

A água é utilizada para abastecimento público e industrial, afastamento de efluentes domésticos e lançamento de efluentes líquidos industriais.

Podem ser citadas como indústrias mais importantes as alimentícias, metalúrgicas, químicas, têxteis, de chapas duras e papelão.

Os municípios de Salto e Indaiatuba são abastecidos pelas águas do ribeirão Piraí, tendo sido consumida a vazão de 0,336 e $0,189 \mathrm{~m}^{3} / \mathrm{s}$ em 1999 (CETESB 1999). As amostragens 
foram realizadas nesse ponto, em janeiro, março, maio, julho, setembro e novembro de 1999, e em janeiro, março, maio, julho e setembro de 2000.

\section{Bacia do rio Piracicaba}

A área de drenagem possui $11.400 \mathrm{~km}^{2}$ e seus principais constituintes são os rios Atibaia, Corumbatai, Jaguari e Piracicaba $(115 \mathrm{~km})$, que tem sua foz no reservatório de Barra Bonita, e os reservatórios de Salto Grande ou Americana (rio Atibaia), Atibainha, Cachoeira e Jaguari.

O solo é principalmente utilizado para pastagens (rebanho de corte e leite), agricultura (cana de açúcar, café, frutos, milho). As atividades urbanas e industriais (papel e celulose, açúcar e álcool, têxteis, metalúrgicas, químicas, curtumes e refinaria de petróleo) são intensas nessa bacia.

A água dessa área destina-se ao abastecimento público e industrial, afastamento de efluentes domésticos e industriais e irrigação de plantações.

Parte das águas da bacia do rio Piracicaba, represadas em suas cabeceiras, são revertidas para abastecimento público $\mathrm{d}$ : outras regiões (Sistema Cantareira, Jundiaí e Campinas). As águas do Atibaia abastecem as cidades de Campinas e Atibaia, com valores de $3,38 \mathrm{~m}^{3} / \mathrm{s}$ e $0,238 \mathrm{~m}^{3} / \mathrm{s}$ em 1999. As cidades de Piracicaba e Americana são igualmente abastecidas pelo Piracicaba, tendo sido captados, em $1999,0,551 \mathrm{~m}^{3} / \mathrm{s}$ e $0,716 \mathrm{~m}^{3} / \mathrm{s}$, respectivamente (CETESB 1999).

Existem vários pontos de captação nessa bacia, sendo 2 no rio Atibaia, na captação para Atibaia, e na captação número 3 de Campinas, na divisa dos municípios de Campinas e Valinhos.

As águas do rio Piracicaba também são importante fonte de abastecimento público, tendo sido monitorados os pontos junto à captação de água de Americana, na localidade de Cariobá e a captação para a cidade de Piracicaba, num local situado na margem esquerda do rio, $2,5 \mathrm{~km}$ a jusante da foz do ribeirão Piracicamirim. Esses seis locais de amostragem foram monitorados em janeiro, março, maio, julho, setembro e novembro de 1999, e em janeiro, março, maio, julho e setembro de 2000.

Na Figura 3, estão apresentados o mapa dessa Bacia e os pontos de captação estudados. 


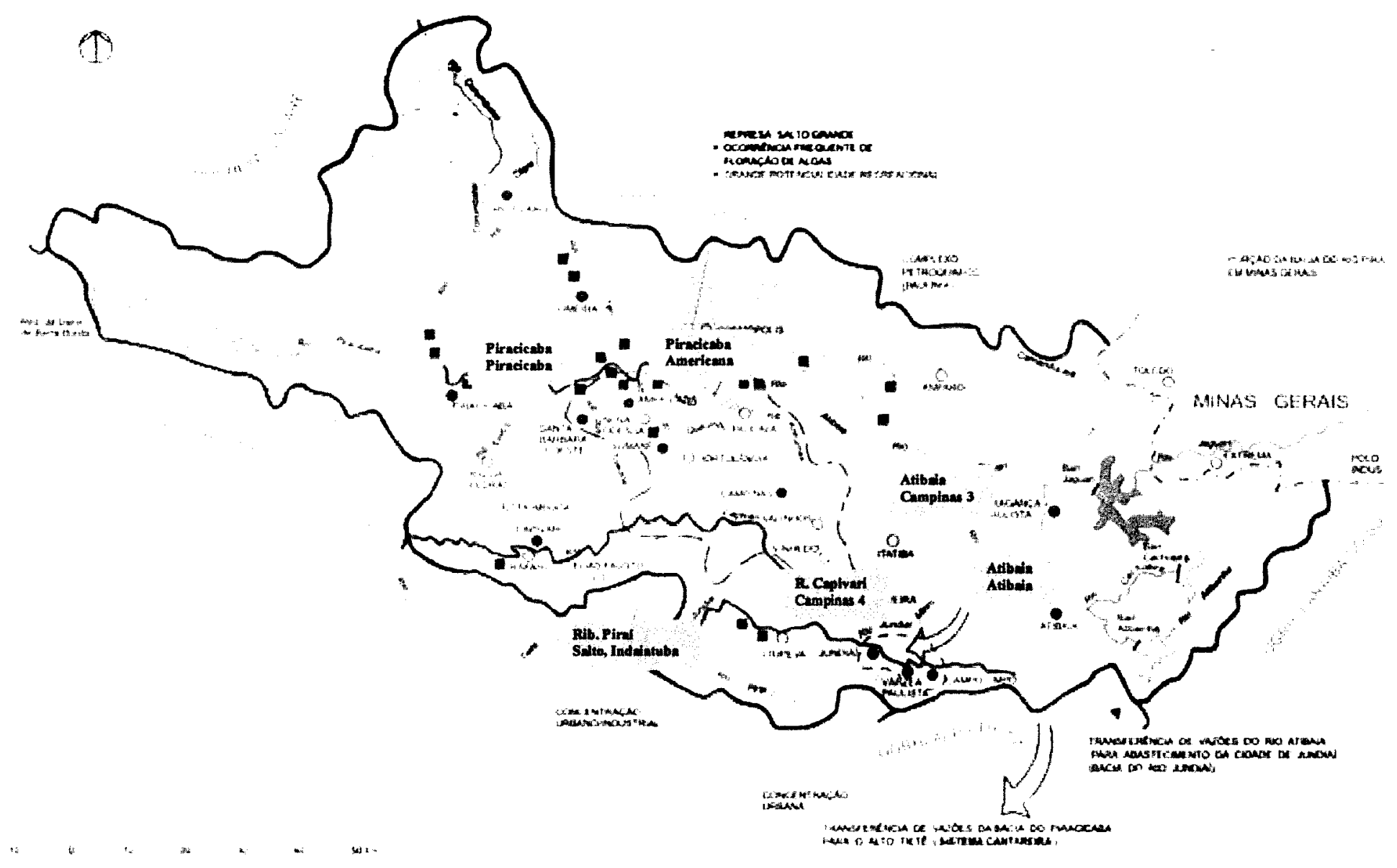

Figura 3 - Unidade de Gerenciamento de Recursos Hídricos 05 - Piracicaba, Capivari, Jundiaí

Fonte: Secretaria do Meio Ambiente do Estado de São Paulo 


\subsubsection{3 - UGRHI 06 - Alto Tietê}

Esta UGRHI abrange a parte superior do rio Tietê, desde as suas cabeceiras até a barragem do reservatório de Pirapora, numa extensão de $133 \mathrm{~km}$, correspondendo a 6.657 $\mathrm{km}^{2}$ de área e compreendendo 34 municípios. Igualmente à Unidade anterior, adota-se para esta UGRHI a subdivisão em bacias hidrográficas.

\section{Bacia do rio Tietê Alto - cabeceiras}

Ocupa uma área de drenagem de $1.889 \mathrm{~km}^{2}$ e tem como constituintes principais o rio Tietê, desde a sua nascente até as proximidades da cidade de São Paulo, na divisa com o município de Itaquaquecetuba $(74 \mathrm{~km})$, e os rios Claro, Paraitinga, Biritiba-Mirim, Jundiaí e Taiaçupeba-Mirim. Quanto aos reservatórios que compõem a bacia tem-se o Ribeirão do Campo (rios Claro e Guaratuba), Ponte Nova (rio Tietê), Paraitinga (rio Paraitinga), Biritiba (rio Biritiba Mirim), Jundiaí (rio Jundiai) e Taiaçupeba (rio Taiaçupeba-Mirim.

Dentre os usos do solo incluem-se a produção de hortifrutigranjeiros, as pastagens naturais e cultivadas, área urbana densamente povoada e elevada industrialização.

As águas são utilizadas para abastecimento público, incluindo a Região Metropolitana de São Paulo, o afastamento de efluentes domésticos de 7 municípios, abastecimento industrial e o lançamento de efluentes liquidos industriais. Dentre as indústrias destacam-se as de produção de papel e celulose, quimicas, mecânicas e alimenticias.

Em 1999, foram captados $1,47 \mathrm{~m}^{3} / \mathrm{s}$ do rio Claro e $2,50 \mathrm{~m}^{3} / \mathrm{s}$ do rio Poço Preto para abastecimento, não havendo pontos de monitoramento nesses locais, uma vez que sua qualidade encontra-se preservada. O reservatório Taiaçupeba fez uso de aproximadamente $7,37 \mathrm{~m}^{3} / \mathrm{s}$, sendo $3,97 \mathrm{~m}^{3} / \mathrm{s}$ provenientes do reservatório Jundiai . Para abastecimento do município de Mogi das Cruzes, foram captados $1,10 \mathrm{~m}^{3} / \mathrm{s}$ do rio Tietê (CETESB 1999).

Foram monitorados o reservatório Taiaçupeba, num ponto a jusante do vertedouro, o rio Jundiai, ponte na rodovia SP-69, que liga Mogi das Cruzes a Taiaçupeba, km 68, a $500 \mathrm{~m}$ da barragem e o rio Tietê, ponte na Av. João XXIII, Vila Suiça, César de Souza, na captação principal de Mogi das Cruzes. As amostragens foram realizadas em janeiro, 
março, maio, julho, setembro e novembro de 1999, e em janeiro, março, maio, julho e setembro de 2000 .

\section{Bacia do reservatório Billings}

Com área de drenagem de $560 \mathrm{~km}^{2}$, esta bacia tem como constituintes principais os reservatórios Billings e do Rio Grande, e os rios Grande, Pequeno, Bororé e Taquacetuba.

Trata-se de área altamente urbanizada, praticamente sem vegetação natural e atividade agricola, com ocupação acelerada, apesar da Lei de Proteção aos Mananciais.

A água é utilizada para abastecimento público, incluindo a Região Metropolitana de São Paulo, abastecimento industrial, afastamento de efluentes domésticos (através do bombeamento das águas do rio Pinheiros) e lançamento de efluentes liquidos industriais.

O manancial do rio Grande, situado na margem direita do reservatório Billings, e que se encontra seccionado do corpo principal desde 1982, abasteceu a região do $\mathrm{ABC}$ com uma vazão de $4,21 \mathrm{~m}^{3} / \mathrm{s}$ em 1999 (CETESB 1999).

Foram monitorados pontos situados no reservatório Billings, no braço do Taquacetuba na baía situada no final da rua Tomekichi Inouye e no reservatório do rio Grande, próximo à rodovia Anchieta, junto à captação da SABESP. As amostragens nesses locais foram efetuadas em janeiro, março, maio, julho, setembro e novembro de 1999, e em janeiro, março, maio, julho e setembro de 2000.

\section{Bacia do reservatório Guarapiranga}

Esta bacia tem área de drenagem de $631 \mathrm{~km}^{2}$. São constituintes principais o rio Guarapiranga e seus afluentes Lavra, Santa Rita, Embu-Guaçú e Embu-Mirim, e o reservatório Guarapiranga.

Os principais formadores do reservatório Guarapiranga são rio Embu-Mirim, que recebe esgotos das cidades de Itapecerica da Serra e São Paulo, e Embu-Guaçú, que recebe os esgotos do município de Embu-Guaçú. Deve-se igualmente acrescentar que, na ocorrência de falta de água nesse reservatório são revertidas para o mesmo as águas da bacia do Capivari-Monos, situada na UGRHI 07 - Baixada Santista (CETESB 1999). 
Quanto à ocupação do solo, a bacia do Guarapiranga possui áreas com características bastante diferentes, sendo Bororé, Riviera, Embu e Itapecerica da Serra com alto grau de urbanização, Parelheiros, Cipó e Embu-Guaçú com áreas de ocupação esparsas, áreas ocupadas mas com baixa densidade populacional e áreas rurais de Itapecerica da Serra e Embu-Guaçú.

A água é utilizada para abastecimento público (20\% do total abastecido para a Região Metropolitana de São Paulo), lançamento de efluentes domésticos de 5 municípios, abastecimento industrial e lançamento de efluentes líquidos industriais nos córregos que afluem para o reservatório. Em 1999, foram utilizado para abastecimento $13,08 \mathrm{~m}^{3} / \mathrm{s}$, incluindo $0,33 \mathrm{~m}^{3} / \mathrm{s}$ da reversão do rio Capivari (CETESB 1999)

Nesta bacia foi monitorado um ponto no reservatório Guarapiranga, na captação da SABESP, junto a casa de bombas, com amostragens realizadas em janeiro, março, maio, julho, setembro e novembro de 1999, e em janeiro, março, maio, julho e setembro de 2000.

\section{Bacia do rio Cotia}

A bacia do rio Cotia, que é o principal constituinte dessa bacia, tem área de drenagem de $250 \mathrm{~km}^{2}$ e possui dois trechos com características próprias: o Cotia Alto, a montante do município de Cotia, e o Cotia Baixo. Incluem-se nessa bacia os reservatórios Pedro Beicht e Cachoeira da Graça.

No que diz respeito aos usos do solo, a região conhecida como Cotia Alto inclui as matas naturais da Reserva Estadual de Morro Grande, enquanto que a área do Cotia Baixo apresenta urbanização (cerca de 400 indústrias) e trechos reflorestados.

A água é utilizada para abastecimento público, incluindo a Região Metropolitana de São Paulo, afastamento de efluentes domésticos, abastecimento industrial e lançamento de efluentes liquidos industriais. Em 1999, o Cotia Alto forneceu para captação $1,43 \mathrm{~m}^{3} / \mathrm{s}$ e o Cotia Baixo 1,03 m³ $/ \mathrm{s}$ (CETESB 1999).

Foram monitorados dois pontos, um deles situado no reservatório das Graças, junto à captação na barragem das Graças, Cotia Alto e o outro no rio Cotia, no canal de captação 
de águas da ETA do Cotia Baixo. As amostragens ocorreram em janeiro, março, maio, julho, setembro e novembro de 1999, e em janeiro, março, maio, julho e setembro de 2000.

\section{Bacia do rio Tietê Alto - zona metropolitana}

A área de drenagem da bacia do rio Tietê Alto - zona metropolitana é de $3.327 \mathrm{~km}^{2}$. Os constituintes principais são o rio Tietê, desde a sua entrada na cidade de São Paulo, na divisa com o município de Itaquaquecetuba, até a barragem de Pirapora $(86 \mathrm{~km})$ e os rios Baquirivu-Guaçú, Gurapira, Tamanduateí, Pinheiros e Juqueri, e córregos Aricanduva e Cabuçu de Baixo. São reservatórios dessa bacia, o Paiva Castro ou Juqueri, no rio Juqueri, o Edgard de Souza e Pirapora, no rio Tietê.

Trata-se de área intensamente urbanizada e industrializada (regiões do $\mathrm{ABC}$, Guarulhos e Osasco), igualmente com desenvolvido setor de prestação de serviços. A sub-bacia do rio Juqueri apresenta áreas de vegetação natural e de reflorestamentos, pastagens naturais e cultivadas e culturas hortifrutigranjeiras.

A água é utilizada para absstecimento público e industrial e afastamento de efluentes domésticos e industriais. Em 1999, foram captados $33,3 \mathrm{~m}^{3} / \mathrm{s}$ dos rios Juqueri, Cachoeira, Atibainha e Jacareí/Jaguari. Ainda de acordo com dados de 1999, para o município de Cajamar foram utilizados $0,060 \mathrm{~m}^{3} / \mathrm{s}$ das águas do ribeirão dos Cristais, e do manancial do Tanque Grande $0,093 \mathrm{~m}^{3} / \mathrm{s}$ para o municipio de Guarulhos (CETESB 1999).

Nessa bacia foram monitorados pontos situados no reservatorio do rio Juqueri, ponte Santa Inês, na rodovia que liga Mairiporã a Franco da Rocha e o Ribeirão dos Cristais, na captação da ETA de Cajamar. As amostragens ocorreram em janeiro, março, maio, julho, setembro e novembro de 1999, e em janeiro, março, maio, julho e setembro de 2000.

O mapa dessa bacia, e os 11 pontos de captação nos quais as análises foram realizadas estão apresentados na Figura 4. 


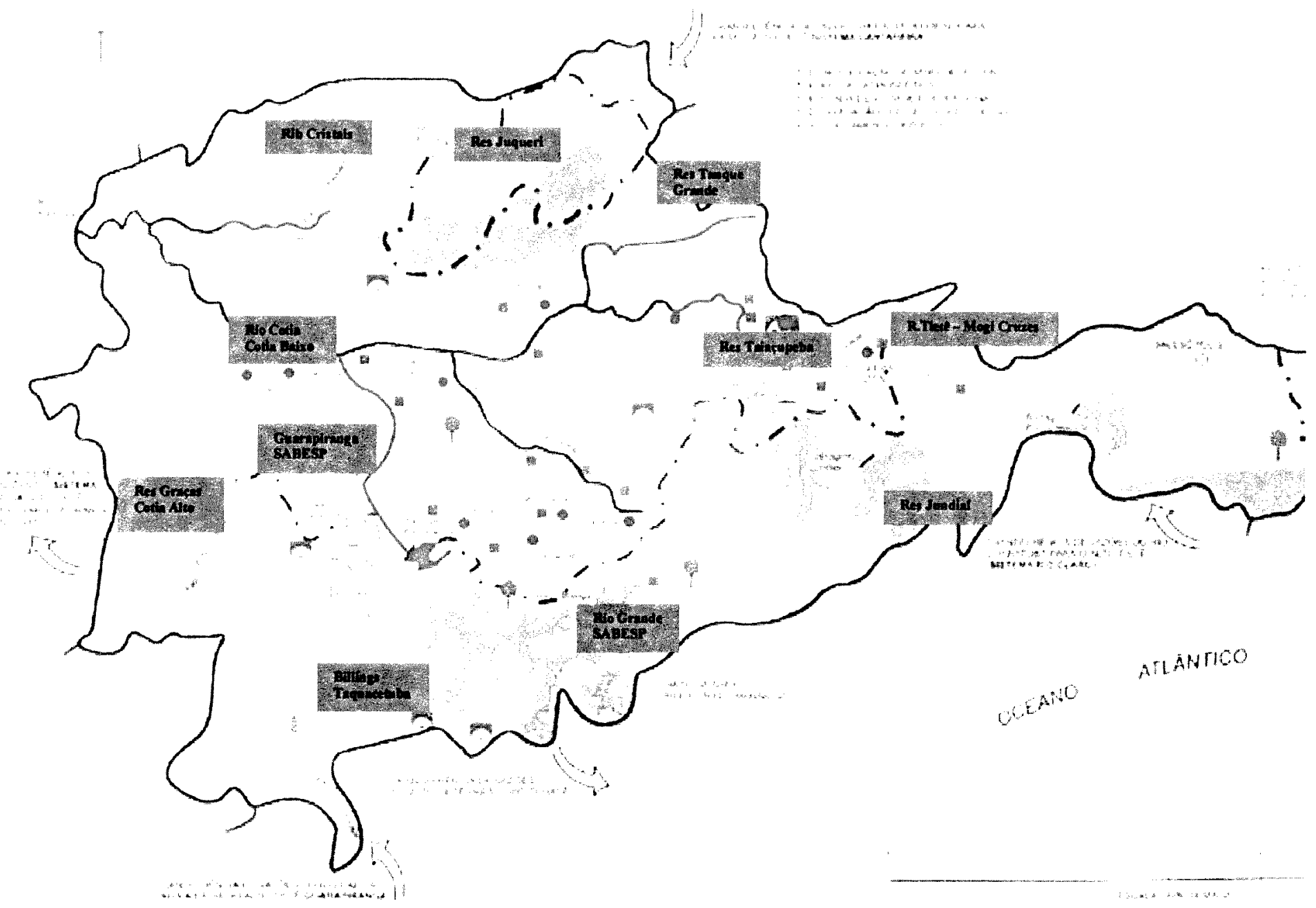

Figura 4--Unidade de Gerenciamento de Recursos Hídricos 06-Alto Tietê

Fonte: Secretaria do Meio Ambiente do Estado de São Paulo 


\subsubsection{4 - UGRHI 07 - Baixada Santista}

Esta UGRHI compreende uma área de $2.887 \mathrm{~km}^{2}$ e situa-se a leste do Estado de São Paulo, sendo composta por 9 municipios.

São principais componentes dessa UGRHI os rios Cubatão, Mogi, Branco e Quilombo, que deságuam no estuário de Santos, e dos rios Itapnhaú, Capivari e Monos.

A ocupação urbana e industrial é predominante na área. Dentre os usos da água incluemse o abastecimento público e industrial, o afastamento de efluentes demésticos e industriais, e recepção dos canais de Fuga I e II da Usina Hidroelétrica de Henry Borden, cujas águas procedem do Sistema Alto Tietê, por meio do reservatório Billings. As atividades industriais concentram-se principalmente nas refinarias de petróleo, indústrias quimicas, petroquimicas, siderúrgicas e de fertilizantes.

O município de Cubatão tem dois pontos de captação, um deles localizado no rio Cubatão e outro no rio Pilões. Em 1999, foram captados $3,68 \mathrm{~m}^{3} / \mathrm{s}$ do rio Cubatão, ponto monitorado pela CETESB (CETESB 1999). O outro ponto avaliado está localizado no reservatório Capivari-Monos, junto à estação de recalque da SABESP. As coletas foram realizadas em janeiro, abril, junho, agosto, outubro e dezembro de 1999 e em fevereiro, abril, junho e agosto de 2000. Na Figura 5 podem ser observados o mapa e os pontos de captação estudados nessa bacia.

\subsubsection{5 - UGRHI 09 - Mogi-Guaçú}

Esta UGRHI possui uma área de $14.653 \mathrm{~km}^{2}$, compreendendo 38 municípios, e tem como constituinte principal o rio Mogi-Guaçú, com extensão de $320 \mathrm{~km}$

O solo é essencialmente utilizado para atividades agrícola, pastoril, granjeira, urbana e industrial. Predominam as plantações de cana de açúcar, café, frutas cítricas, milho e algodão. A água é utilizada para abastecimento público e industrial, afastamento de efluentes domésticos e industriais e irrigação de plantações. Destacam-se dentre as atividades industriais, as alimenticias, usinas, engenhos e destilarias, curtumes, papel e celulose e metalúrgicas. 


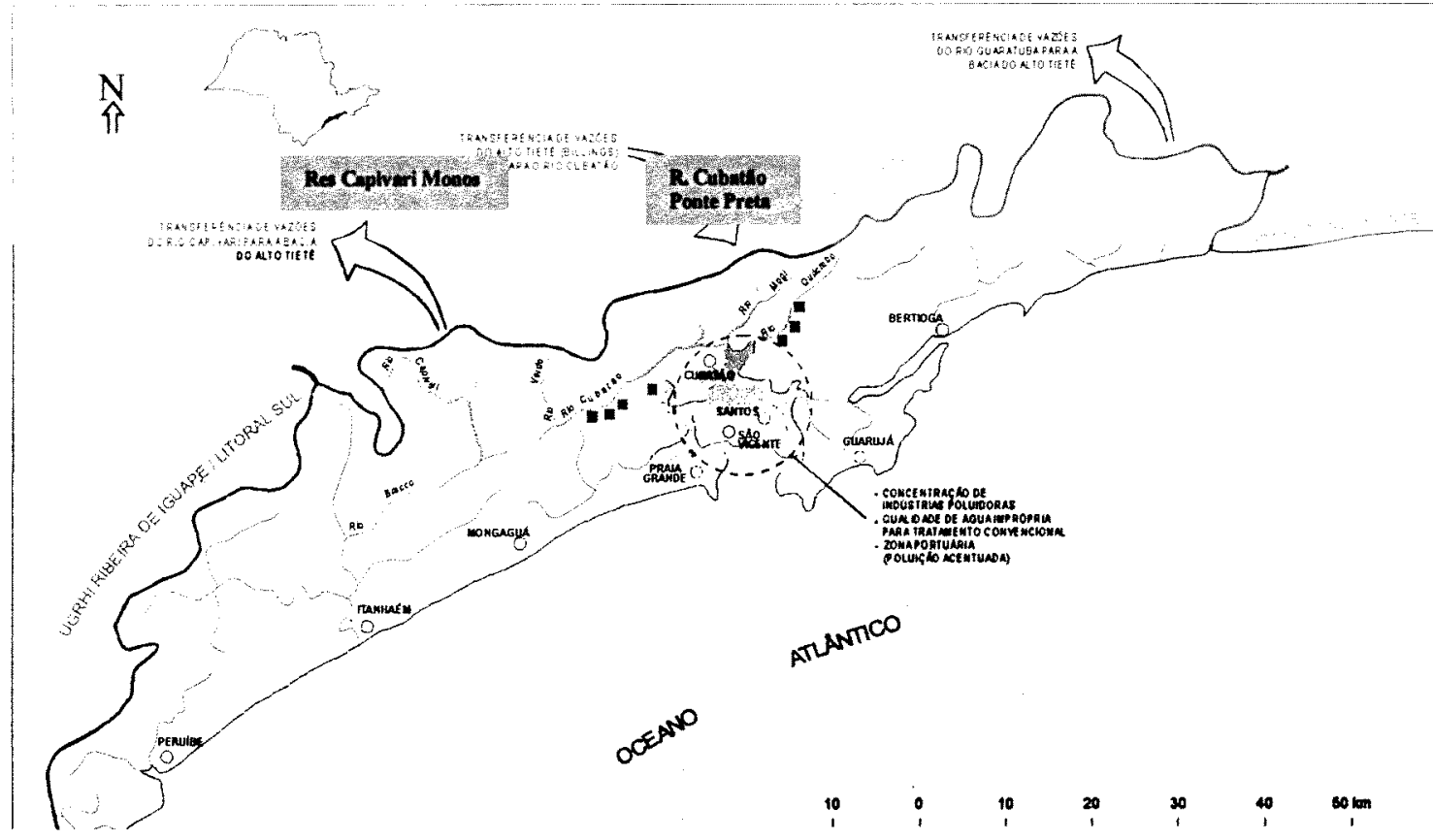

Figura 5 -Unidade de Gerenciamento de Recursos Hídricos 07 - Baixada Santista Fonte: Secretaria do Meio Ambiente do Estado de São Paulo 
A Academia de Força Aérea de Pirassununga tem uma ETA própria, no rio MogiGuaçú, na qual está localizado o ponto de monitoramento da CETESB. Em 1999, foram captados desse local $0,080 \mathrm{~m}^{3} / \mathrm{s}$ (CETESB 1999). As coletas nesse ponto foram efetuadas em janeiro, abril, junho, outubro e dezembro de 1999, e fevereiro, abril, junho e agosto de 2000 .

O mapa dessa bacia, com indicação do ponto de captação analisado, estão apresentados na Figura 6.

\subsubsection{6 - UGRHI 10 - Sorocaba - Médio Tietê}

Esta UGRHI tem uma área de $14.850 \mathrm{~km}^{2}$ e é compreende 33 municipios. Para a Rede Básica de Monitoramento da CETESB, esta Unidade é subdividida em duas bacias hidrográficas, a Bacia do rio Sorocaba e a Bacia do rio Tietê Médio-Superior. Somente foi monitorado um ponto do captação na bacia do rio Sorocaba.

\section{Bacia do rio Sorocaba}

Esta bacia possui área de drenagem de $5.020 \mathrm{~km}^{2}$ e tem como constituinte principal o rio Sorocaba, que percorre aproximadamente $80 \mathrm{~km}$ até a margem esquerda do rio Tietê e rios Pirajibu, Ipanema, Tatui e Sarapuí, incluindo o reservatório de Itupararanga no rio Sorocaba. No que diz respeito aos usos do solo, além da ocupação urbana e industrial, cerca de $25 \%$ da região bacia corresponde a mata natural. Uma porcentagem importante $(32,5 \%)$ é ocupada por pastagens e culturas variadas, principalmente milho e cana de açúcar.

A água é utilizada para abastecimento público e industrial, afastamento de efluentes domésticos e industriais e irrigação de plantações. As principais indústrias são as têxteis, alimentícias, metalúrgicas, mecânicas, químicas, engenhos e curtumes.

Nesta bacia, é monitorado o reservatório de Itupararanga, situado na cabeceira do rio Sorocaba, num local próximo à barragem, na estrada que liga Ibiúna a Votorantim, no ponto de captação do municipio de Sorocaba. Trata-se da única fonte de abastecimento público dessa cidade. Em 1999 foram utilizados, com esse objetivo 1,51 m³ $/ \mathrm{s}$ com esse objetivo (CETESB 1999). 


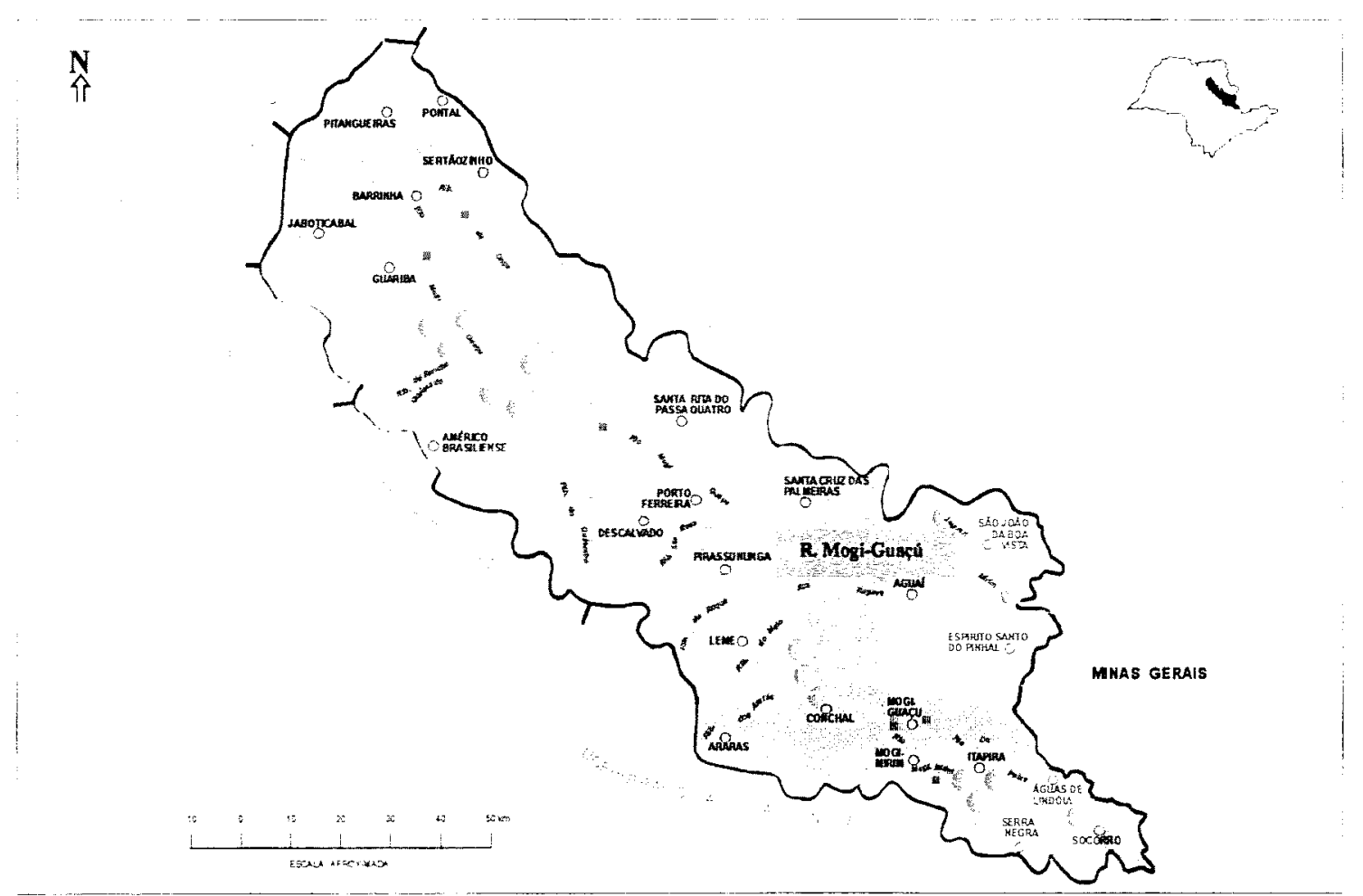

Figura 6 - Unidade de Gerenciamento de Recursos Hídricos 09 - Mogi-Guaçú Fonte: Secretaria do Meio Ambiente do Estado de São Paulo 
As coletas tiveram lugar em janeiro, março, maio, julho, setembro e novembro de 1999 , e em janeiro, março, maio, julho e setembro de 2000.

Na Figura 7 estão representados o mapa dessa bacia e o ponto de captação estudado.

\subsubsection{7 -UGRHI 15 - Turvo-Grande}

Com área de $15.975 \mathrm{~km}^{2}$ e 64 municípios, esta Unidade tem como constituintes principais os rios São Domingos, o ribeirão da Onça, os rios Turvo, Preto e Grande, desde a Usina Hidroelétrica de Marimbondo até a foz do rio Paranaíba, e como reservatório, os de Água Vermelha e Ilha Solteira (parcial).

Os usos do solo incluem atividades urbanas, industriais e a agropecuária, destacando-se o plantio de café, soja, milho, frutas citricas, arroz e cana de açúcar

A água é empregada para abastecimento público e industrial, afastamento de efluentes domésticos e industriais e irrigação de plantações. Dentre as atividades industriais citam-se como mais significativas as indústrias alimenticias, os engenhos, as usinas e os curtumes

Em 1999, a vazão média captada para abastecimento para a cidade de São José do Rio Preto foi de $0,450 \mathrm{~m}^{3} / \mathrm{s}$ (CETESB 1999).

Nessa bacia, as análises foram realizadas no reservatório do Rio Preto, na captação da ETA de São José do Rio Preto, em coletas realizadas em janeiro, junho, agosto, outubro e dezembro de 1999, e em fevereiro, abril, junho e agosto de 2000

O mapa dessa bacia. bem como o ponto de captação analisado podem ser observados na Figura 8

\subsubsection{8 - UGRHI 17 - Médio Paranapanema}

Esta Unidade possui uma área de $16.763 \mathrm{~km}^{2}$ e é composta por 42 municípios.

O rio Paranapanema e seus afluentes, desde o reservatório da Usina Hidroelétrica de Xavantes até a de Capivara, rios Capivara e Turvo, e o reservatório Capivara são os principais constituintes dessa Bacia. 


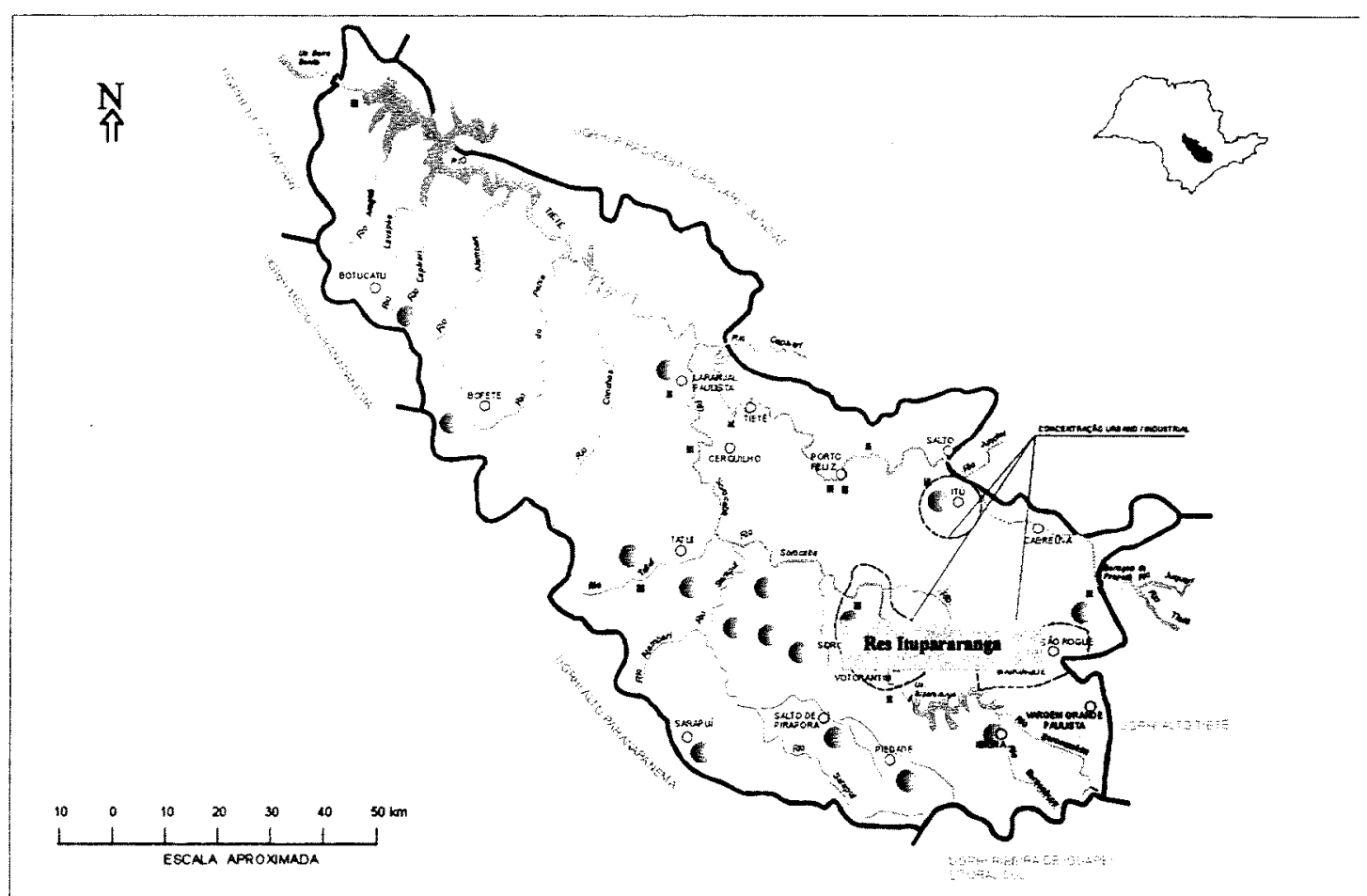

Figura 7 - Unidade de Gerenciamento de Recursos Hídricos - Sorocaba - Médio Tietê Fonte: Secretaria do Meio Ambiente do Estado de São Paulo 


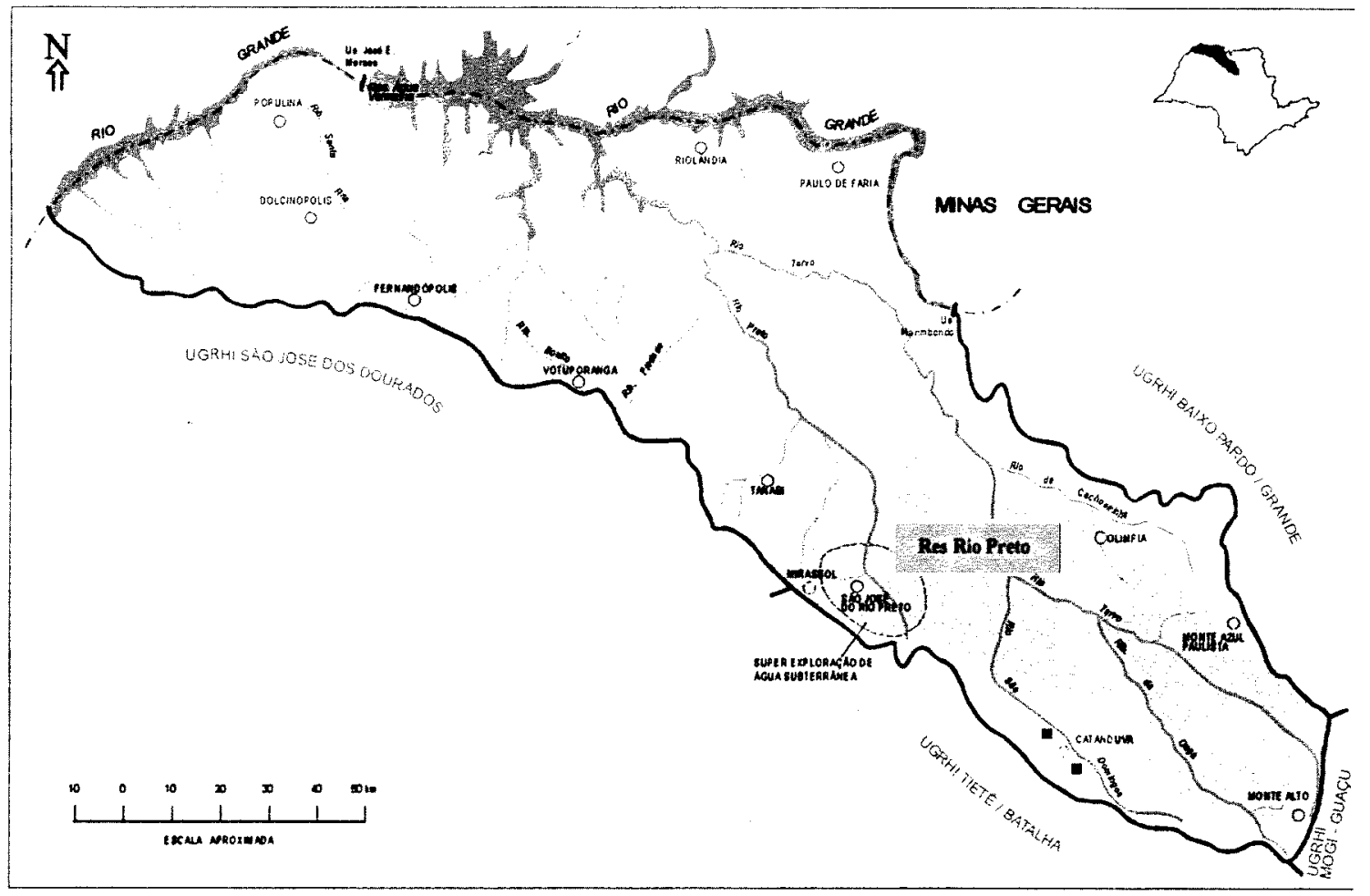

Figura 8 -Unidade de Gerenciamento de Recursos Hídricos 15- Turvo/Grande

Fonte: Secretaria do Meio Ambiente do Estado de São Paulo 
O solo é utilizado para atividades agrícolas, tais como cultura de soja, cana de açúcar, milho, mandioca e arroz, destacando-se pela elevada taxa de aplicação de agroquímicos, a exceção das culturas do milho e da mandioca. Outros usos do solo incluem a ocupação urbana e industrial e extração mineral.

A água é utilizada para abastecimento público e industrial, afastamento de efluentes domésticos, lançamentos de efluentes industriais e irrigação de plantações.

As principais indústrias são alimentícias, os frigorificos, fecularias, engenhos e destilarias

A água que abastece a população do município de Ourinhos provém de um ponto de captação localizado no rio Pardo, ponte na rodovia Raposo Tavares, no km 381. Em 1999 foram captados nesse manancial $0,275 \mathrm{~m}^{3} / \mathrm{s}$ (CETESB 1999). Esse ponto foi monitorado pela CETESB em janeiro, abril, junho, agosto, outubro e dezembro de 1999, e em fevereiro, abril, junho e agosto de 2000

$\mathrm{Na}$ Figura 9 podem ser observados o mapa e o ponto de captação no qual as coletas e análises foram realizadas.

\subsubsection{0-UGRHI 21 - Peixe}

Com área de $12.393 \mathrm{~km}^{2}$ e 26 municipios, esta Unidade tem como principal constituinte o rio do Peixe, formado pela confluência de vários rios, córregos e ribeirões, e como reservatório o de Quatiara

Além das atividades urbanas e industriais, o solo é ocupado por áreas de pastagens e culturas de café, milho e cana de açúcar.

A água é utilizada para abastecimento público e industrial, afastamento de efluentes domésticos, lançamento de efluentes industriais e irrigação de plantações.

Dentre as principais atividades industriais citam-se as agroindústrias e as indústrias alimenticias 


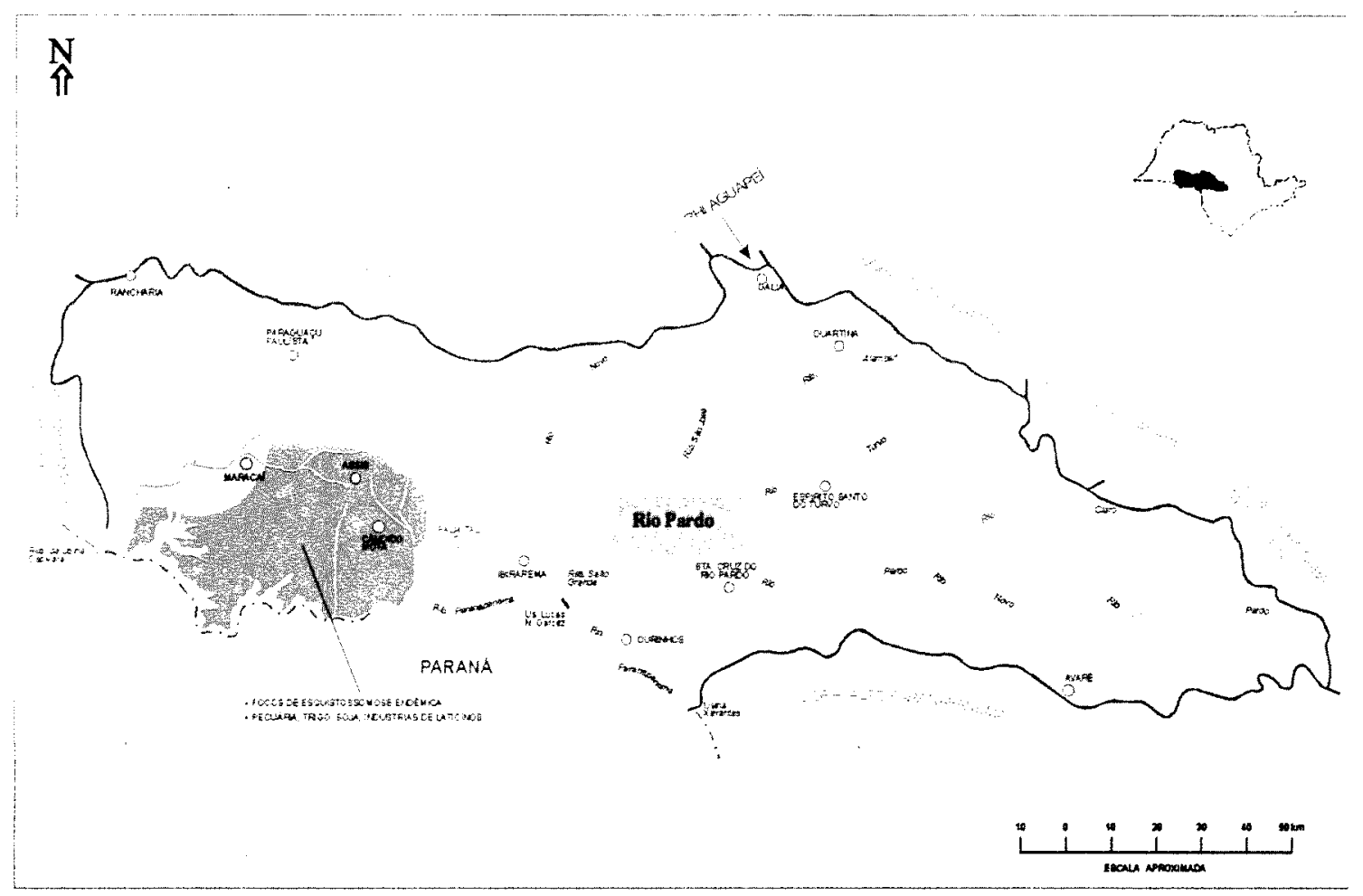

Figura 9 - Unidade de Gerenciamento de Recursos Hídricos 17 - Médio Paranapanema Fonte: Secretaria do Meio Ambiente do Estado de São Paulo 
Parte do município de Marília é abastecido pelas águas captadas no rio do Peixe $\left(0,15 \mathrm{~lm}^{3} / \mathrm{s}\right.$ em 1999), que também é utilizado para abastecimento de parte da cidade de Presidente Prudente. A CETESB monitora o ponto situado no rio do Peixe, na ponte que liga Marilia a

Assis. As coletas nesse local foram realizadas em janeiro, abril, junho, agosto, outubro e dezembro de 1999, e em fevereiro, abril, junho e agosto de 2000.

Na Figura 10 estão apresentados o mapa e o ponto de captação estudado nessa bacia.

\subsubsection{1 - UGRHI 22 - Pontal do Paranapanema}

Esta UGRHI compreende uma área de $11.838 \mathrm{~km}^{2}$ e possui 21 municípios. Os rios Santo Anastácio, Paranapanema e seus afluentes, desde a Usina Hidroelétrica de Capivara até a foz no rio Paraná são seus principais constituintes.

Quanto aos usos do solo, é preponderante a pecuária extensiva, culturas de soja, cana de açúcar, milho, mandioca, arroz e frutos. As demais ocupações referem-se a atividades urbana, industrial e cobertura florestal.

A água é utilizada para abastecimento público e industrial, afastamento de efluentes domésticos e industriais, e irrigação de plantações.

As indústrias principais são as alimentícias, os curtumes, matadouros e destilarias de álcool.

O local monitorado situa-se no rio Paraná, na ponte da rodovia que liga Presidente Epitácio a Bataguaçú, fonte que abastece toda a cidade de Presidente Epitácio, do qual foram captados $0,091 \mathrm{~m}^{3} / \mathrm{s}$ em 1999. As coletas foram realizadas em janeiro, abril, junho, outubro e dezembro de 1999, e em fevereiro, abril, junho e agosto de 2000

Podem ser observados na Figura 11 o mapa e o ponto de captação analisado nessa bacia. 


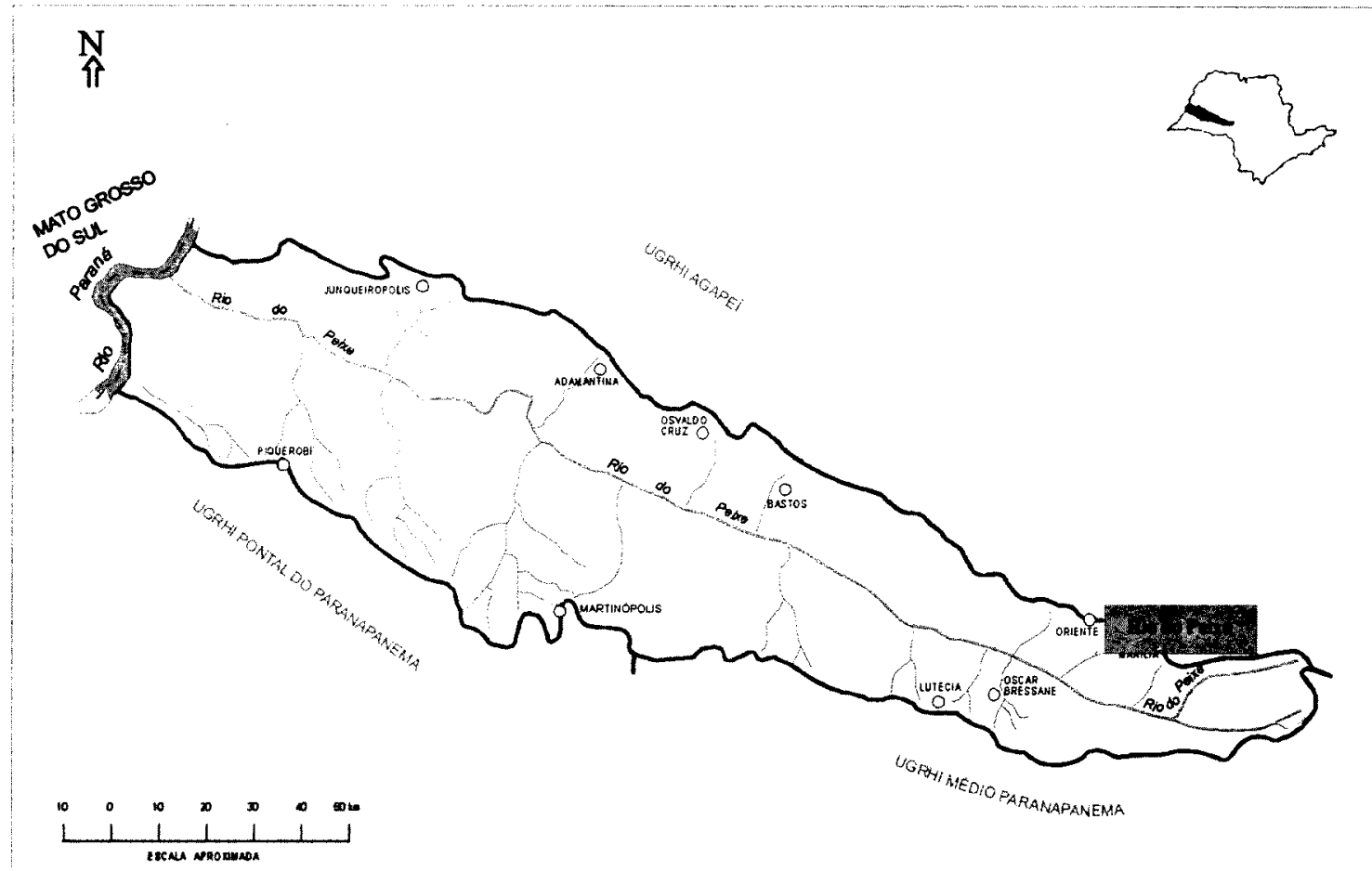

Figura 10 - Unidade de Gerenciamento de Recursos Hídricos 21 -Peixe

Fonte: Secretaria do Meio Ambiente do Estado de São Paulo 


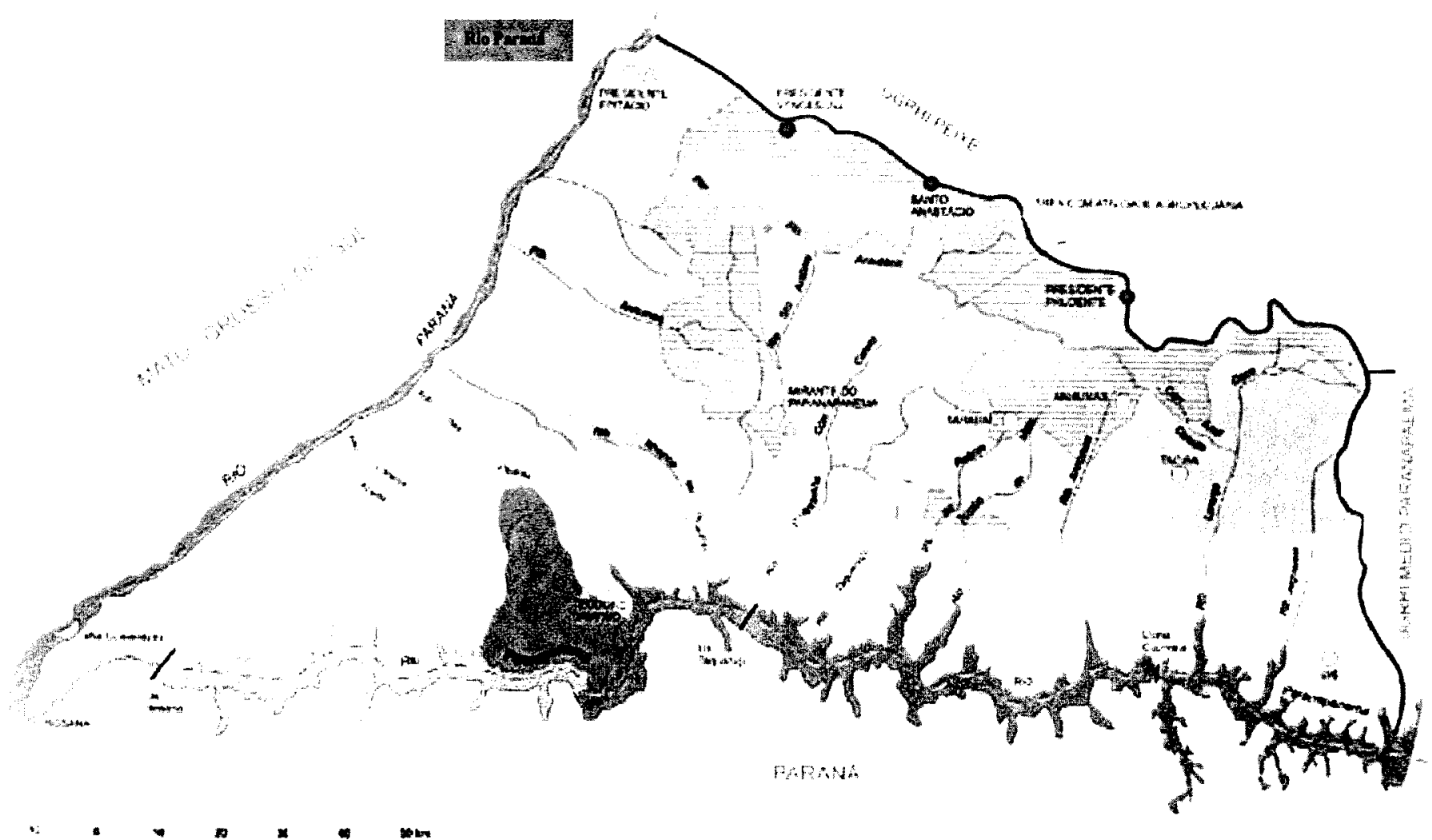

Figura 11 Unidade de Gerenciamento de Recursos Hídricos 22 - Pontal do Paranapanema Fonte: Secretaria do Meio Ambiente do Estado de São Paulo 


\subsection{2 - Técnicas de Coleta, Preservação e Transporte das Amostras}

As coletas foram realizadas de acordo com os procedimentos descritos no "Standard Methods" (AMERICAN PUBLIC HEALTH ASSOCIATION, 1998). Foram utilizados frascos de polipropileno, previamente lavados com detergente não tóxico, enxaguados com água comum e com água destilada (último enxágüe), esterilizados em autoclave durante 15 minutos, a $121^{\circ} \mathrm{C}$. Para a análise de Giardia e Cryptosporidium, de cada ponto de amostragem, foram coletados $10 \mathrm{~L}$ de água, em dois frascos de $5 \mathrm{~L}$. Para a análise dos indicadores bacterianos de contaminação, coliformes e estreptococos fecais, e Clostridium perfringens, foram coletados $500 \mathrm{~mL}$ de água de cada ponto de amostragem. Para neutralização de eventuais resíduos de cloro e metais pesados foram adicionados, antes da esterilização, $0,1 \mathrm{~mL}$ de tiossulfato de sódio $1,8 \%$ e $0,3 \mathrm{ml}$ de EDTA sódico (etileno-diamino- tetra acetato de sódio) 15\%, pH 6,5, para cada 100mL de amostra a ser coletada.

As amostras foram identificadas por um número que constou dos frascos e das fichas de coleta, nas quais ainda foram ainda registrados, data e hora da coleta, descrição do local, ocorrência de chuva nas $24 \mathrm{~h}$ anteriores à amostragem, coloração, temperatura e pH da água, e temperatura do ar. Quaisquer outras condições locais que pudessem ter influência nas análises foram igualmente registradas.

Os frascos foram imediatamente transportados ao Laboratório, em caixas de isopor contendo gelo comum para manter a temperatura das amostras abaixo de $10^{\circ} \mathrm{C}$, as amostras sendo analisadas no máximo $24 \mathrm{~h}$ após a coleta. 


\section{2 - Análise dos Protozoários Giardia sp e Cryptosporidium sp através da Técnica de Concentrạ̧ão por Floculação com Carbonato de Cálcio (VESEY et al. 1993) e Microscopia de Imunofluorescência}

\subsection{1 - Procedimento para Concentração da Amostra}

Os frascos de $5 \mathrm{~L}$ contendo as amostra foram muito bem homogeneizados e seu conteúdo transferido para um balão de fundo chato com capacidade para $12 \mathrm{~L}$, estéril. Separadamente foram adicionados, $100 \mathrm{~mL}$ de cloreto de cálcio $1 \mathrm{M}$, e, em seguida $100 \mathrm{~mL}$ de bicarbonato de sódio $1 \mathrm{M}$, e o conteúdo do balão foi homogeneizado. $\mathrm{O}$ pH foi acertado a 10,0 através da adição de solução de hidróxido de sódio $1 \mathrm{M}$ e assim foi mantido durante $12 \mathrm{~h}$ (“overnight") à temperatura ambiente. O sobrenadante foi retirado através de aspiração a vácuo, cuidadosamente para não desfazer o precipitado de carbonato de cálcio formado. O precipitado formado foi dissolvido através da adição de $200 \mathrm{~mL}$ de ácido sulfâmico e todo o conteúdo foi agitado vigorosamente durante 15 segundos. A suspensão obtida foi transferida para tubos cônicos de centrífuga de $250 \mathrm{~mL}$. O balão foi enxaguado com $200 \mathrm{~mL}$ de solução de Tween $800,01 \%$, agitando-se vigorosamente, e esse liquido também transferido para tubos cônicos de centrífuga de $250 \mathrm{~mL}$. O processo acima citado foi repetido com mais $100 \mathrm{~mL}$ da solução de Tween 80 $0,01 \%$. Todos os tubos foram centrifugados a $3000 \mathrm{~g}$ durante 10 minutos. Os sobrenadantes foram retirados deixando-se um volume de cerca de $50 \mathrm{~mL}$ para ressuspensão dos "pellets".Após ressuspensão de todos os "pellets", o material foi transferido para um único tubo cônico de $50 \mathrm{~mL}$, que foi centrifugado a $3000 \mathrm{~g}$ durante 10 minutos. Todo o sobrenadante foi retirado. Todos tubos cônicos de $250 \mathrm{~mL}$ utilizados na centrifugação inicial foram lavados com $50 \mathrm{~mL}$ de solução de Tween $800,01 \%$ e esse liquido foi utilizado para ressuspender o "pellet" obtido no tubo cônico de $50 \mathrm{~mL}$. Após nova centrifugação a $3000 \mathrm{~g}$ o sobrenadante foi retirado, deixando-se um volume de cerca de $10 \mathrm{~mL}$ para ressuspensão do "pellet". O volume final do "pellet" foi anotado e em seguida foi realizada a etapa de imunofluorescência. 


\subsection{2 - Reação de Imunofluorescência}

Todos os reagentes do Kit de imunofluorescência direta foram retirados da geladeira e somente utilizados após atingirem a temperatura ambiente. Os poços da lâmina foram devidamente identificados para colocação da amostra, controle negativo e controle positivo. Foram pipetados $10 \mu \mathrm{L}$ do controle positivo (proveniente do Kit, ou de uma suspensão de cistos de Giardia e oocistos de Cryptosporidium), controle negativo (proveniente do Kit) e amostra (6 poços para a amostra) nos poços respectivos das lâminas. $\mathrm{O}$ material foi muito bem espalhado em cada poço das lâminas com alças de inoculação descartáveis, e as lâminas secas ao ar. A cada poço foi adicionada uma gota do anticorpo (anticorpos monoclonais para Giardia sp e Cryptosporidium sp conjugados a isotiocianato de fluoresceina) e uma gota de contra-corante (solução de negro de eriocromo). As lâminas foram incubadas em câmara úmida (caixa de plástico hermeticamente fechada contendo papel toalha umedecido), durante 1 hora a temperatura ambiente. Cada lâmina foi enxaguada com a solução tampão fornecida com o Kit para remover o excesso de anticorpo e contra-corante, tomando-se cuidado para não contaminar um poço da lâmina com o material de outro poço. As lâminas foram então cobertas com papel absorvente, para eliminação do o excesso de líquido, sem permitir entretanto a secagem completa das mesmas. Foram adicionados 1 a 2 gotas do meio de montagem e colocadas as lâmínulas.

\subsection{3 - Leitura}

Utilizando-se a objetiva de 40X, são examinados inicialmente os controles positivo e negativo para verificar se os reagentes utilizados na coloração funcionaram adequadamente. A seguir cada poço da amostra é examinado, percorrendo-se sistematicamente toda a extensão da mesma, de cima para baixo, ou da esquerda para a direita. Os objetos esféricos ou ovais com fluorescência verde brilhante, mais acentuada

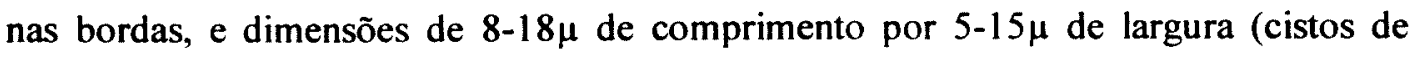
Giardia sp) e de 3-7 $\mu$ de diâmetro (oocistos de Cryptosporidium sp) são identificados e registrados em formulário apropriado. 


\subsection{4 - Cálculo dos Resultados}

A concentração de cistos de Giardia sp e oocistos de Cryptosporidium sp foi calculada, através da seguinte fórmula:

Cistos/oocistos por $\mathrm{L}=\mathrm{N}^{\circ}$ de cistos ou oocistos $\mathrm{X} 100 \mathrm{X}$ volume do "pellet"

$10 \mathrm{~L}$

\subsection{5 - Controles Negativos}

Periodicamente foram realizados controles negativos que consistiram na floculação com carbonato de cálcio de volumes de $10 \mathrm{~L}$ de água destilada.

\subsection{6 - Determinação da Porcentagem de Recuperação do Método}

Para determinar-se a porcentagem de recuperação do método, $10 \mathrm{~L}$ de água destilada foram contaminados com uma suspensão contendo 100 cistos de Giardia lamblia de origem humana (cepa H-3) e 100 oocistos de Cryptosporidium parvum de origem bovina (cepa lowa). Essa suspensão foi preparada em Tween 80 0,01\%, a partir de uma preparação concentrada dos parasitas $\left(10^{7}\right.$ cistos $/ \mathrm{L}$ e $10^{6}$ oocistos $\left./ \mathrm{L}\right)$ em formol $5 \%$ obtida da Waterborne Inc. Essa amostra artificialmente contaminada foi então processada da mesma forma que as amostras de águas brutas. 


\section{3 - Análise dos Indicadores Bacterianos de Contaminação Fecal (AMERICAN PUBLIC HEALTH ASSOCIATION 1998)}

\subsection{1 - Coliformes Fecais (AMERICAN PUBLIC HEALTH ASSOCIATION 1998; CETESB 1992)}

Para cada amostra foi preparada uma série de 5 tubos de ensaio $18 \times 150 \mathrm{~mm}$ contendo $10 \mathrm{~mL}$ do meio Al concentração dupla e 2 a 7 séries de 5 tubos de ensaio $16 \times 150 \mathrm{~mm}$ contendo $10 \mathrm{~mL}$ do meio Al concentração simples, dependendo do grau de contaminação da amostra a ser analisada;

A amostra foi agitada, no mínimo 25 vezes, e foi preparada uma série de diluições decimais da mesma $\left(10^{-1}\right.$ a $\left.10^{-6}\right)$, inoculando-se $10 \mathrm{~mL} \mathrm{em}$ frascos contendo $90 \mathrm{~mL}$ de água de diluição;

A amostra foi novamente agitada 25 vezes, e foi iniciada a inoculação dos tubos, pipetando-se $10 \mathrm{~mL}$ da mesma em cada um dos 5 tubos da série contendo o meio Al concentração dupla;

A segunda série de tubos foi inoculada, pipetando-se $1 \mathrm{~mL}$ de amostra, em cada um dos 5 tubos da primeira série contendo o meio Al concentração simples;

Foi a seguir inoculado $1 \mathrm{~mL}$ das diluições $10^{-1}$ a $10^{-6} \mathrm{em}$ cada um dos cinco tubos das demais séries de tubos contendo o meio Al concentração simples;

Todos os tubos foram incubados a $35 \pm 0,5^{\circ} \mathrm{C}$ durante 3 horas e a seguir a $44,5 \pm 0,2^{\circ} \mathrm{C}$ durante $21 \pm 2$ horas

Foi efetuada a leitura dos tubos, considerando-se resultado positivo para coliformes fecais a produção de gás; 
Foi calculado o NMP/100mL (Número Mais Provável) de coliformes fecais a partir do número de tubos positivos utilizando-se a Tabela Índice de NMP e Limites de Confianca de 95\% (Anexo 2).

\subsection{2 - Estreptococos Fecais (AMERICAN PUBLIC HEALTH ASSOCIATION 1984; CETESB 1984)}

Para cada amostra foi preparada uma série de 5 tubos de ensaio $18 \times 150 \mathrm{~mm}$ contendo $10 \mathrm{~mL}$ do caldo dextrose azida concentração dupla e 2 a 5 séries de 5 tubos de ensaio $16 \times 150 \mathrm{~mm}$ contendo $10 \mathrm{~mL}$ do caldo dextrose azida concentração simples, dependendo do grau de contaminação da amostra a ser analisada;

A amostra foi agitada, no mínimo 25 vezes, e foi preparada uma série de diluições decimais da mesma $\left(10^{-1}\right.$ a $\left.10^{-4}\right)$, inoculando-se $10 \mathrm{~mL}$ em frascos contendo $90 \mathrm{~mL}$ de água de diluição;

A amostra foi novamente agitada 25 vezes e foi iniciada a inoculação dos tubos, pipetando-se $10 \mathrm{~mL}$ da mesma em cada um dos 5 tubos da série contendo caldo dextrose azida concentração dupla;

A segunda série de tubos foi inoculada, pipetando-se $1 \mathrm{~mL}$ de amostra, em cada um dos 5 tubos da primeira série contendo o caldo dextrose azida concentração simples;

Foi a seguir inoculado $1 \mathrm{~mL}$ das diluições $10^{-1}$ a $10^{-4} \mathrm{em}$ cada um dos cinco tubos das demais séries de tubos contendo o caldo dextrose azida concentração simples;

Todos os tubos foram incubados a $35 \pm 0,5^{\circ} \mathrm{C}$ durante $24 \mathrm{~h}$, examinando-se, após esse período os tubos quanto à presença de turbidez, resposta presuntiva positiva para estreptococos fecais;

Os tubos negativos após $24 \mathrm{~h}$ foram reincubados, a $35 \pm 0,5^{\circ} \mathrm{C}$, durante $24 \mathrm{~h}$ adicionais e foi verificada a presença de turbidez; 
As culturas dos tubos presuntivos positivos após 24 e 48 horas foram estriadas em placas contendo ágar PSE e incubadas a $35 \pm 0,5^{\circ} \mathrm{C}$ durante $24 \mathrm{~h}$;

A presença de colônias negras ou marrons com halo marrom foi considerado resultado confirmativo positivo para estreptococos fecais;

Utilizando-se a Tabela Índice de NMP e Linites de Confianca 95\% (Anexo 2) foi calculado o NMP/100mL de estreptocos fecais a partir do número de tubos positivos cujo resultado foi confirmado no ágar PSE.

\subsection{3 - Clostridum perfringens (HSMO 1977; CETESB 1993)}

A amostra de água foi aquecida a $75^{\circ} \mathrm{C}$, durante 10 minutos, para destruição das formas vegetativas;

Foi preparada para cada amostra, 1 série de 5 tubos de ensaio $18 \times 150 \mathrm{~mm}$ contendo $10 \mathrm{~mL}$ do meio DRCM concentração dupla e 2 a 5 séries de 5 tubos de ensaio $16 \times 150 \mathrm{~mm}$ contendo $10 \mathrm{~mL}$ do meio DRCM concentração simples, dependendo do grau de contaminação da amostra a ser analisada;

Os tubos de DRCM concentração dupla e simples a serem utilizados foram aquecidos em água fervente durante cerca de 10 minutos e rapidamente resfriados para remoção do ar;

As soluções preparadas de sulfito de sódio e citrato férrico foram diluídas à metade $\mathrm{e}$ foi acrescentado $0,4 \mathrm{~mL}$ dessas soluções aos tubos de DRCM concentração dupla e $0,2 \mathrm{~mL}$ aos tubos de DRCM concentração simples;

A amostra foi lentamente homogeneizada para evitar-se sua aeração;

Foi iniciada a inoculação dos tubos, pipetando-se $10 \mathrm{~mL}$ de amostra em cada um dos 5 tubos da série contendo caldo DRCM concentração dupla; 
Foi preparar uma série de diluições decimais da mesma $\left(10^{-1}\right.$ a $\left.10^{-4}\right)$, inoculando-se $10 \mathrm{~mL}$ em frascos contendo $90 \mathrm{~mL}$ de água de diluição;

A segunda série de tubos foi inoculada pipetando-se $1 \mathrm{~mL}$ de amostra em cada um dos 5 tubos da primeira série contendo o meio DRCM concentração simples;

Foi a seguir inoculado $1 \mathrm{~mL}$ das diluições $10^{-1}$ a $10^{-4}$ em cada um dos cinco tubos das demais séries contendo o meio DRCM concentração simples;

Todos os tubos foram colocados na jarra de anaerobiose juntamente com os sistemas gerador e indicador, que foram ativados segundo as instruções do fabricante, e a jarra foi incubada à temperatura de $35 \pm 0,5^{\circ} \mathrm{C}$ durante $48 \pm 3 \mathrm{~h}$;

Foi efetuada a leitura considerando como resultado presuntivo positivo todos os tubos que apresentaram turvação;

Foi inoculado $0,1 \mathrm{~mL}$ das culturas dos tubos presuntivos positivos em tubos contendo leite tornassolado previamente fervidos e resfriados para eliminação do ar;

Todos os tubos foram colocados os tubos na jarra de anaerobiose, juntamente com os sistemas gerador e indicador, que foram ativandos segundo as instruções do fabricante $e$ a jarra foi incubada à temperatura de $35 \pm 0,5^{\circ} \mathrm{C}$ durante $48 \pm 3 \mathrm{~h}$;

Foi efetuada a leitura considerando-se resultado confirmativo positivo todos os tubos que apresentaram coagulação do leite, acidificação evidenciada pela coloração rosa do meio e formação de gás, causando rompimento dos coágulos (fermentação turbulenta do leite);

Utilizando-se a Tabela Índice de NMP e Limites de Confiança 95\% (Anexo 2) foi calculado o NMP/100mL de Clostridium perfringens, a partir do número de tubos positivos cujo resultado foi confirmado no leite tornassolado. 


\section{4 - Análise Estatistica dos Resultados}

Objetivando determinar-se a eventual existência de uma relação quantitativa entre as concentrações de Giardia sp e de cada um dos indicadores de contaminação fecal, foi calculado o coeficiente de correlação de Spearman (SIEGEL 1975), não tendo sido assim necessário assumir nenhuma hipótese quanto à forma das distribuições. $O$ nivel de significância adotado foi de $5 \%$ e foi utilizado o aplicativo STATISTICA 98. Essa análise foi realizada não só considerando-se a totalidade dos resultados obtidos nas 10 UGRHIs $(n=278)$ como também os dados de cada UGRHI $(n=20,67,112,20,10,11$, $9,10,10$ e 10 para as UGRHIs $2,5,6,7,9,10,15,17,21$ e 22 respectivamente.

Do ponto de vista estatístico, não puderam ser avaliadas as relações quantitativas eventualmente existentes entre as concentrações de Cryptosporidium sp e de cada um dos indicadores de contaminação fecal, devido à baixa porcentagem de amostras positivas observada para esse protozoário, conforme será apresentado detalhadamente no item Resultados. 


\section{5 - RESULTADOS}

\section{1 - Resultados Globais das Análises de Giardia sp e Cryptosporidium sp}

Dentre o total de 278 amostras analisadas nas 10 UGRHIs, a Giardia sp e o Cryplosporidium sp foram detectados em $76(27 \%)$ e $7(2,5 \%)$ das amostras respectivamente ( Figura 12). As concentrações obtidas variaram de 0 a 521 cistos/L para a Giardia sp e 0 a 20 oocistos/L para o Cryplosporidium sp.
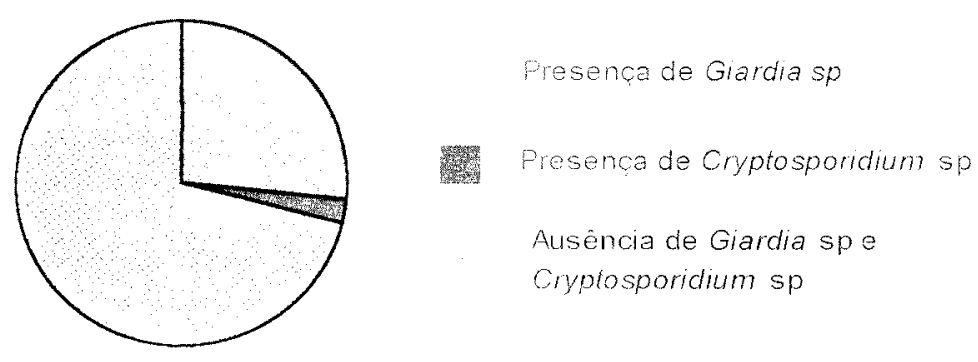

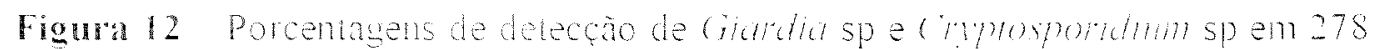
amostras de aguas brutas de lo lo GRHIs

Em cada $4 m$ dos 28 ponos de captaçào foram obtidas porcentagens de positividade ariaveis entre e $100 \%$ para a Girmdlu sp. Na maior parte desses pontos. essas porcentagens shumam-se entre 0 e $20 \%$ Esses resultados estão representados graficamente na Figura 13

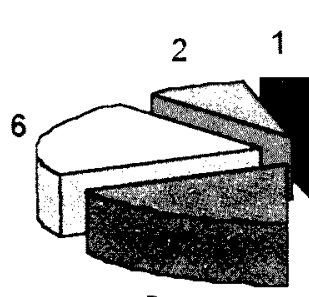

5

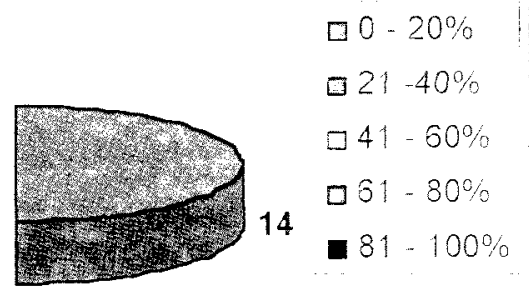

Figura 13 - Faixas de porcentagens de positividade para Giardia sp nos 28 pontos de captação. 
Dentre os 28 pontos de captação analisados, nas 10 UGRHIs, 19 apresentaram resultados positivos para Giardia $\mathrm{sp}$, e as concentrações máximas do protozoário obtidas em cada um desses pontos, estão representadas graficamente na Figura 14.

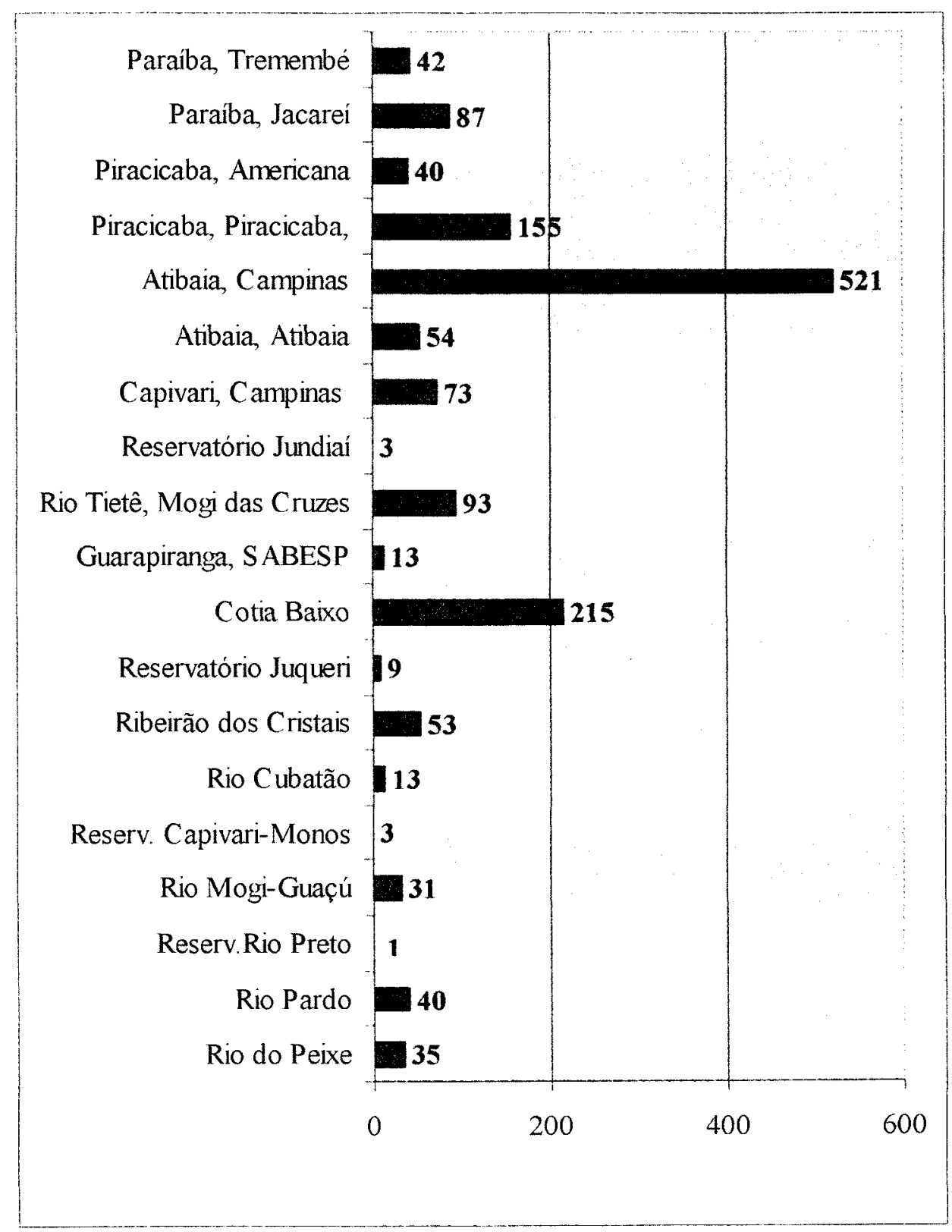

Figura 14 - Concentrações máximas de Giardia sp nos 19 pontos de captação com resultados positivos. 


\section{2 - Controles Negativos}

Não foram detectados cistos de Giardia sp ou oocistos de Cryptosporidium nos controles negativos realizados com as amostras de água destilada analisadas.

\section{3 - Determinação da Porcentagem de Recuperação do Método}

Não foi possivel determinar-se a porcentagem de recuperação do método, devido à grande quantidade de material particulado fluorescente nas lâminas preparadas a partir das amostras de água destilada artificialmente contaminadas, o que impossibilitava a leitura.

5.4 - Resultados das Análises de Giardia sp, Cryptosporidium sp e das Bactérias Indicadoras de Contaminação Fecal, Coliformes fecais, Estreptococos fecais e Clostridium perfringens em cada UGRHI

\subsection{1 - UGRHI 02 - Paraíba do Sul}

\subsubsection{1 - Giardia sp e Cryptosporidium sp}

No rio Paraiba, o protozoário Giardia sp foi detectado em $40 \%(4 / 10)$ das amostragens realizadas no ponto localizado junto à captação da SABESP em Tremembé, e em 50\%(3/6) das amostragens realizadas no ponto situado junto á captação do municipio de Jacareí. No $3^{\circ}$ ponto de captação dessa bacia, o reservatório do Jaguari, ponte na rodovia que liga Santa Isabel a Igaratá, no municipio de Santa Isabel. a Giardia sp não foi detectada. O Cryptosporidium sp foi observado apenas no rio Paraiba, junto à captação da SABESP no município de Tremembé, na amostragem de agosto de 1999, na concentração de 2 oocistos/L. Esses resultados estão apresentados na Tabela 1. 


\subsubsection{2 - Coliformes Fecais, Estreptococos fecais e Clostridium perfringens}

As concentrações desses indicadores foram bastante elevadas no rio Paraiba, na captação da SABESP em Tremembé, tendo sido ultrapassado, em todas as amostragens, o limite de 1.000 coliformes fecais $/ 100 \mathrm{~mL}$, estabelecido pela Resolução 20/76 do CONAMA (Conselho Nacional do Meio Ambiente), para águas de classe 2 , na qual se enquadra esse corpo d'água. Os estreptococos fecais também foram detectados em altas densidades nesse ponto, um pouco inferiores àquelas observadas para os coliformes, enquanto que as concentrações de $C$. perfringens foram mais baixas

No rio Paraiba, captação de Jacarei, foram verificadas variações acentuadas nos niveis de coliformes fecais $(8-11.000 \mathrm{NMP} / 100 \mathrm{~mL})$. O limite CONAMA 20 (1.000 coliformes fecais $/ 100 \mathrm{~mL}$ ) foi superado em 3 das 6 amostragens. Por outro lado, as densidades de estreptococos fecais e $C$. perfringens variaram pouco nesse ponto

Nas amostras coletadas no reservatório do Jaguari, ponte na rodovia que liga Sta. Isabel a Igaratá, no municipio de Sta. Isabel, as concentrações de coliformes e estreptococos fecais foram muito mais baixas. O limite CONAMA para águas de classe 1 (200 coliformes fecais/100mL) somente foi superado em 2 das 10 amostragens realizadas. As densidades de C. perfringens entretanto, foram bastante semelhantes àquelas observadas nos demais pontos dessa bacia. Na Figura 15, estão apresentadas as médias geométricas das concentrações desses indicadores nos pontos de captação dessa UGRHI. 
Tabela 1-Resultados das análises de Giardia sp e Cryptosporidium sp nos pontos de captação da UGRHI 02 - Paraíba do Sul.

\begin{tabular}{|c|c|c|c|}
\hline $\begin{array}{l}\text { Data de } \\
\text { Coleta }\end{array}$ & Local da Coleta & $\begin{array}{l}\text { Giardia } \mathrm{sp} \\
\text { (cistos/L) }\end{array}$ & $\begin{array}{l}\text { Cryptosporidium } \mathrm{sp} \\
\text { (oocistos } / \mathrm{L})\end{array}$ \\
\hline $29 / 01 / 99$ & & A & A \\
\hline $14 / 04 / 99$ & & A & A \\
\hline $16 / 06 / 99$ & Reservatório do Jaguari, & A & A \\
\hline $11 / 08 / 99$ & ponte na rodovia que liga & A & A \\
\hline $20 / 10 / 99$ & Santa Isabel a Igaratá & A & A \\
\hline $08 / 12 / 99$ & no municipio de Santa Isabel & A & A \\
\hline $16 / 02 / 00$ & & A & A \\
\hline $05 / 04 / 00$ & & A & A \\
\hline $28 / 06 / 00$ & & A & A \\
\hline $15 / 08 / 00$ & & $\mathrm{~A}$ & A \\
\hline $29 / 01 / 99$ & & 42 & $\bar{A}$ \\
\hline $14 / 04 / 99$ & & A & A \\
\hline $16 / 06 / 99$ & Rio Paraíba, junto à captação & 3 & A \\
\hline $11 / 08 / 99$ & da SABESP em & 2 & 2 \\
\hline $20 / 10 / 99$ & Tremembé & $\mathrm{A}$ & A \\
\hline $08 / 12 / 99$ & & A & A \\
\hline $16 / 02 / 00$ & & A & A \\
\hline $05 / 04 / 00$ & & A & A \\
\hline $28 / 06 / 00$ & & 3 & A \\
\hline $15 / 08 / 00$ & & A & A \\
\hline $20 / 10 / 99$ & & A & $\bar{A}$ \\
\hline $08 / 12 / 99$ & & A & A \\
\hline $16 / 02 / 00$ & Rio Paraíba, junto à & 20 & A \\
\hline $05 / 04 / 00$ & captação no municipio & 87 & A \\
\hline $28 / 06 / 00$ & de Jacareí & 57 & A \\
\hline $15 / 08 / 00$ & & $\mathrm{~A}$ & A \\
\hline
\end{tabular}




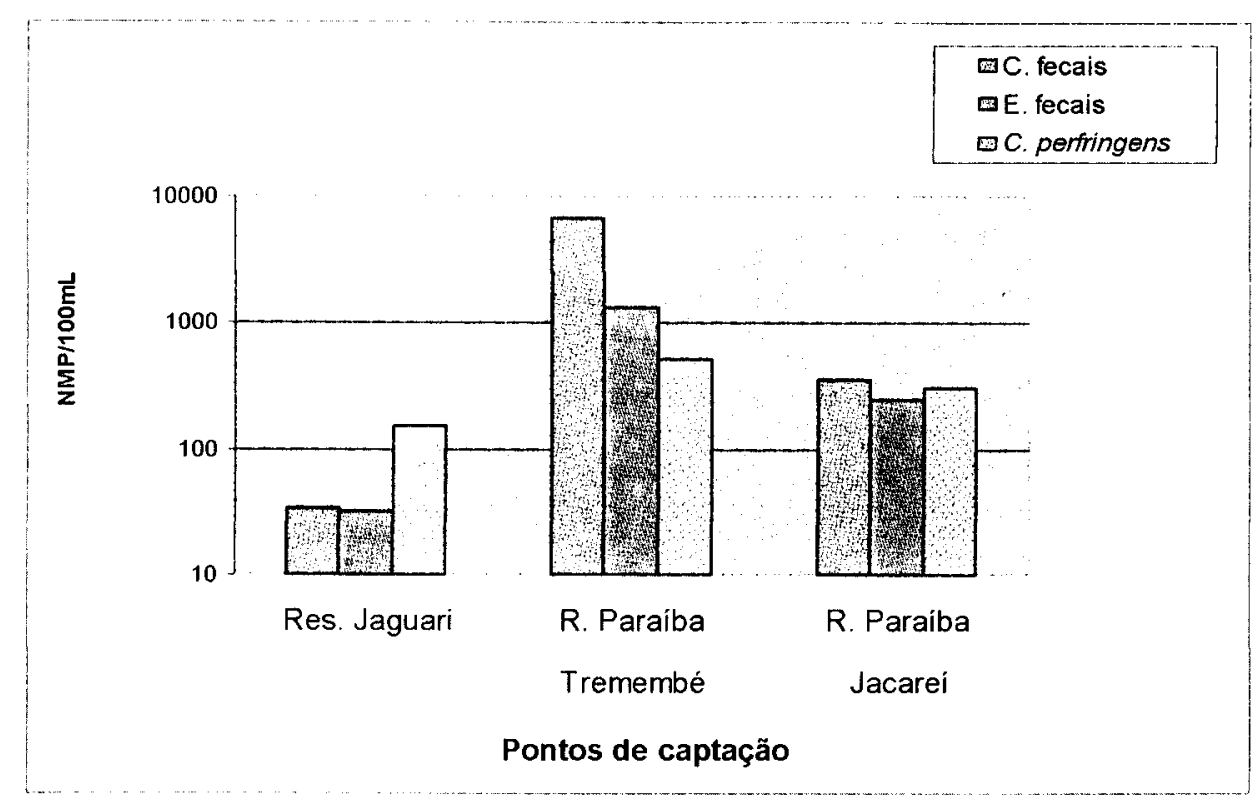

Figura 15 - Médias geométricas das concentrações de coliformes fecais, estreptococos fecais e $(r$. perfiringens em amostras coletadas nos pontos de captação da UGRHI 02

\subsection{2 - UGRHI 05 - Piracicaba, Capivari, Jundiaí}

\subsubsection{1 - Giardia sp e Cryptosporidium sp}

As análises de Giardia sp nos dois pontos localizados no rio Piracicaba forneceram resultados bastante distintos: na captação de água de Americana, junto à localidade de Cariobá, o protozoário foi detectado em 27\% (3/11) das amostragens somente. Em contraste, no ponto situado na margem esquerda do rio, $2,5 \mathrm{~km}$ a jusante da foz do ribeirão Piracicamirim, na captação de Piracicaba, $80 \%$ das amostras analisadas $(8 / 10)$ foram positivas, com densidades superiores a 100 cistos/L em alguns meses. O protozoário Cryptosporidium sp não foi detectado em nenhuma das amostragens realizadas nesses pontos. Esses resultados podem ser observados na Tabela 2. 
Tabela 2 - Resultados das análises de Giardia sp e Cryptosporidium sp nos pontos de captação do rio Piracicaba (UGRHI 05).

\begin{tabular}{|c|c|c|c|}
\hline $\begin{array}{l}\text { Data de } \\
\text { Coleta }\end{array}$ & Local da Coleta & $\begin{array}{l}\text { Giardia } \mathrm{sp} \\
\text { (cistos/L) }\end{array}$ & $\begin{array}{l}\text { Cryplosporidium } \mathrm{sp} \\
\text { (oocistos/L) }\end{array}$ \\
\hline $19 / 01 / 99$ & & A & $\bar{A}$ \\
\hline $02 / 03 / 99$ & & A & A \\
\hline $04 / 05 / 99$ & & A & A \\
\hline $13 / 07 / 99$ & Rio Piracicaba, junto à & 13 & A \\
\hline $08 / 09 / 99$ & captação de água de & 20 & A \\
\hline $03 / 11 / 99$ & Americana, junto à & A & A \\
\hline $04 / 01 / 00$ & localidade de Cariobá & A & A \\
\hline $14 / 03 / 00$ & & 40 & A \\
\hline $02 / 05 / 00$ & & A & A \\
\hline $04 / 07 / 00$ & & A & A \\
\hline $27 / 09 / 00$ & & A & A \\
\hline $19 / 01 / 99$ & & A & A \\
\hline $02 / 03 / 99$ & & 17 & A \\
\hline $04 / 05 / 99$ & Rio Piracicaba, margem & 36 & A \\
\hline $13 / 07 / 99$ & esquerda, $2,5 \mathrm{~km}$ a jusante & 60 & A \\
\hline $08 / 09 / 99$ & da foz do ribeirão & 155 & A \\
\hline $03 / 11 / 99$ & Piracicamirim, na captação & 3 & A \\
\hline $04 / 01 / 00$ & de Piracicaba & A & A \\
\hline $14 / 03 / 00$ & & 30 & A \\
\hline $02 / 05 / 00$ & & 110 & A \\
\hline $04 / 07 / 00$ & & 153 & A \\
\hline
\end{tabular}

A- ausente

Quanto aos pontos localizados no rio Atibaia, na captação $n^{\circ} 3$ de Campinas, na divisa dos municípios de Campinas e Valinhos, e na captação de Atibaia, a Giardia sp foi observada em 55\% (5/9) e 40\% (4/10) das amostras, respectivamente. No primeiro desses pontos as densidades foram altas, atingindo 521 cistos/L em março de 1999, a maior concentração desse protozoário detectada nesse trabalho. Não foi verificada a presença de (ryptosporidium sp nesses locais (Tabela 3). 
Tabela 3 - Resultados das análises de Giardia sp e Cryptosporidium sp nos pontos de captação do rio Atibaia (UGRHI 05).

\begin{tabular}{|c|c|c|c|}
\hline Data de & Local da Coleta & Giardia sp & Cryptosporidium $\mathrm{sp}$ \\
\hline $11 / 01 / 99$ & & $\bar{A}$ & A \\
\hline $23 / 03 / 99$ & & 521 & A \\
\hline $11 / 05 / 99$ & & A & A \\
\hline $27 / 07 / 99$ & Rio Atibaia, na captação & 160 & A \\
\hline $14 / 09 / 99$ & $\mathrm{n}^{\circ} 3$ de Campinas, na divisa & 10 & A \\
\hline $16 / 11 / 99$ & dos municipios de & 27 & A \\
\hline $11 / 01 / 00$ & Campinas e Valinhos & A & A \\
\hline $21 / 03 / 00$ & & A & A \\
\hline $09 / 05 / 00$ & & 67 & A \\
\hline $11 / 01 / 99$ & $\because$ & A & A \\
\hline $23 / 03 / 99$ & & A & A \\
\hline $11 / 05 / 99$ & & A & A \\
\hline $27 / 07 / 99$ & Rio Atibaia na captação & 54 & A \\
\hline $14 / 09 / 99$ & de Atibaia & 20 & A \\
\hline $16 / 11 / 99$ & & A & A \\
\hline $11 / 01 / 00$ & & A & A \\
\hline $21 / 03 / 00$ & & 7 & A \\
\hline $09 / 05 / 00$ & & 10 & A \\
\hline $19 / 09 / 00$ & & A & A \\
\hline
\end{tabular}

Dentre as amostras coletadas no rio Capivari, na captação da ETA 4, na cidade de Campinas, $50 \%(5 / 10)$ apresentaram resultados positivos para Giardia sp, a concentração mais elevada tendo sido observada em setembro de 1999, e nessa amostra tambem foram detectados 3 oocistos/L de Cryptosporidium $\mathrm{sp}$.

Em nenhuma das amostras coletadas no reservatório do ribeirão Pirai, na barragem de captação dos municipios de Salto e Indaiatuba, foi observada a presença de Giardia sp e Cryptosporidium sp. Esses resultados estão apresentados na Tabela 4 . 
Tabela 4 - Resultados das análises de Giardia sp e Cryptosporidium sp nos pontos de captação do rio Capivari e do reservatório do ribeirão Piraí (UGRHI 05).

\begin{tabular}{|c|c|c|c|}
\hline $\begin{array}{l}\text { Data de } \\
\text { Coleta }\end{array}$ & Local da Coleta & $\begin{array}{l}\text { Giardia } \mathrm{sp} \\
\text { (cistos/L) }\end{array}$ & $\begin{array}{c}\text { Cryptosporidium } \mathrm{sp} \\
\text { (oocistos/L) }\end{array}$ \\
\hline $11 / 01 / 99$ & & 10 & A \\
\hline $23 / 03 / 99$ & & A & A \\
\hline $11 / 05 / 99$ & & A & A \\
\hline $27 / 07 / 99$ & Rio Capivari, na captação & 27 & A \\
\hline $14 / 09 / 99$ & da ETA 4 da cidade de & 73 & 3 \\
\hline $16 / 11 / 99$ & Campinas & 10 & A \\
\hline $11 / 01 / 00$ & & A & A \\
\hline $21 / 03 / 00$ & & A & A \\
\hline $09 / 05 / 00$ & & 13 & A \\
\hline $19 / 09 / 00$ & & A & A \\
\hline $11 / 01 / 99$ & & A & A \\
\hline $16 / 03 / 99$ & & A & A \\
\hline $25 / 05 / 99$ & & A & A \\
\hline $13 / 07 / 99$ & Reservatório do ribeirão & A & A \\
\hline $28 / 09 / 99$ & Piraí, na barragem de & A & A \\
\hline $09 / 11 / 99$ & Captação dos municipios de & A & $\mathrm{A}$ \\
\hline $25 / 01 / 00$ & Salto e Indaiatuba & A & A \\
\hline $28 / 03 / 00$ & & A & A \\
\hline $23 / 05 / 00$ & & A & A \\
\hline $25 / 07 / 00$ & & A & A \\
\hline $26 / 09 / 00$ & & A & A \\
\hline
\end{tabular}

\subsubsection{2 - Coliformes Fecais, Estreptococos fecais e C. perfringens}

Foram observadas concentrações elevadas dos indicadores de contaminação fecal em todas as amostras coletadas no rio Piracicaba: no ponto localizado na margem esquerda $2.5 \mathrm{~km}$ a jusante da foz do ribeirão Piracicamirim, na captação de 
Piracicaba, o limite estabelecido pelo CONAMA para águas de classe 2 do (1.000 coliformes fecais $/ 100 \mathrm{~mL}$ ) foi ultrapassado em todas as coletas No ponto situado junto à captação de água de Americana, na localidade de Cariobá, as concentrações de todas as bactérias foram mais baixas, e foi atendido o limite CONAMA (1.000 coliformes fecais $/ 100 \mathrm{~mL}$ ) em 4 de 11 amostragens, nas quais as concentrações dos outros indicadores também apresentaram uma diminuição, menos acentuada no caso do C. perfringens.

O rio Atibaia também apresentou má qualidade bacteriológiea nos dois pontos estudados: nas amostras coletadas no ponto situado na captação $n^{\circ} 3$ de Campinas, na divisa dos municipios de Campinas e Valinhos, as concentrações de coliformes fecais superaram o limite CONAMA ( 1.000 coliformes fecais $/ 100 \mathrm{~mL})$ em todas as coletas, e os estreptococos fecais e o $C$. perfringens estiveram presentes em concentrações elevadas igualmente. No outro ponto estudado nesse rio (rio Atibaia, na captação de Atibaia) embora as concentrações dessas bactérias tenham sido menores, somente foi atendido o padrão CONAMA em 2 das 10 amostragens realizadas.

Quanto ao ponto localizado no rio Capivari, na captação da ETA 4 da cidade de Campinas, verificaram-se concentrações altas dos três indicadores analisados, com atendimento ao padrão CONAMA (1.000 coliformes fecais/100mL) nas coletas realizadas nos meses de novembro de 1999 e maio de 2000 somente. Nesses meses, entretanto, não foram observadas diminuições muito acentuadas nas concentrações de estreptococos fecais e $C$. perfringens.

No reservatório do ribeirão Pirai, na barragem de captação dos municípios de Salto e Indaiatuba, observou-se melhor qualidade no que diz respeito a esses indicadores, uma vez que o limite CONAMA ( 1.000 coliformes fecais/100mL) foi ultrapassado apenas nas três primeiras coletas realizadas nesse ponto (janeiro, março e maio de 1999). Nessas coletas, os estreptococos fecais e o (. perfringens também estiveram presentes em concentrações relativamente elevadas, e mantiveram-se em niveis proporcionais aos coliformes fecais em quase todas as outras campanhas.

As médias geométricas das concentrações desses indicadores nos 6 pontos de captação dessa UGRHI podem ser observadas nas Figuras 16, 17 e 18 


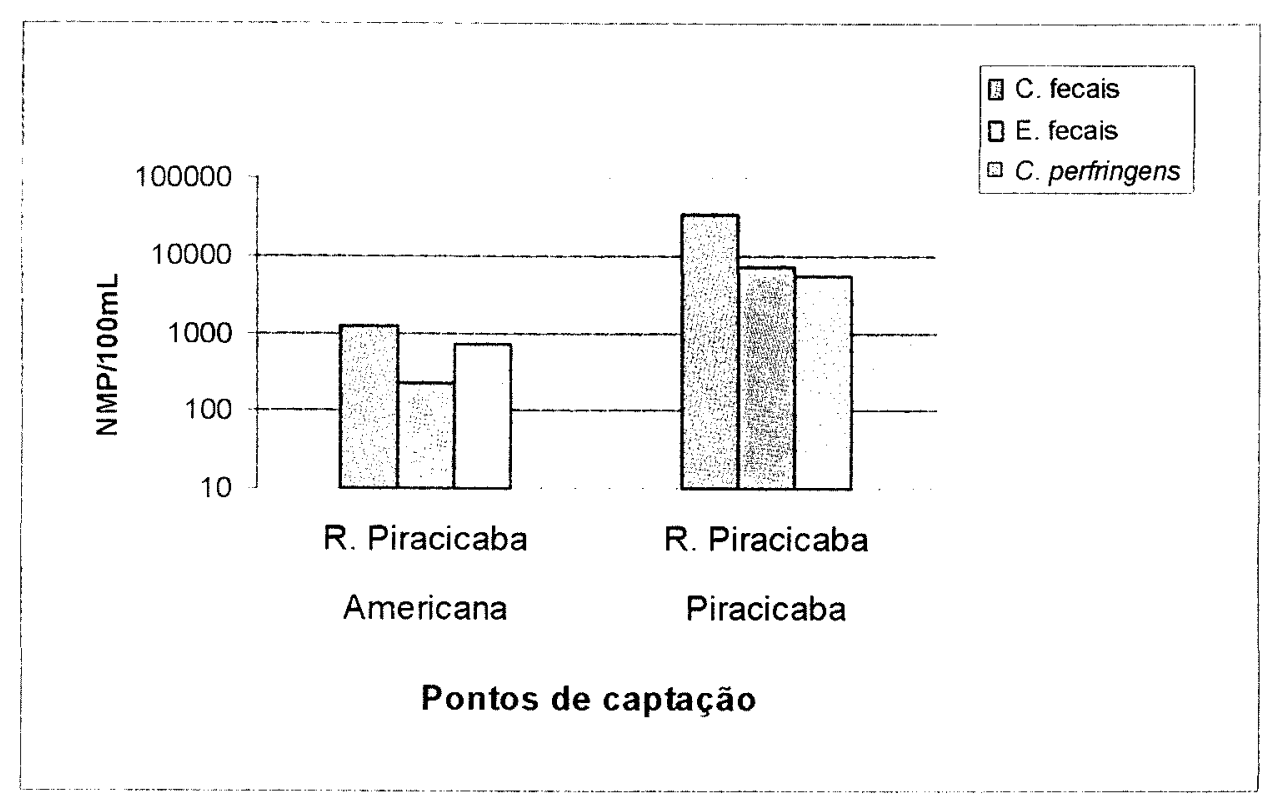

Figura 16 - Médias geométrica das concentrações de coliformes fecais, estreptococos fecais e C. perfringens em amostras coletadas nos pontos de captação do rio Piracicaba (UGRHI 05).

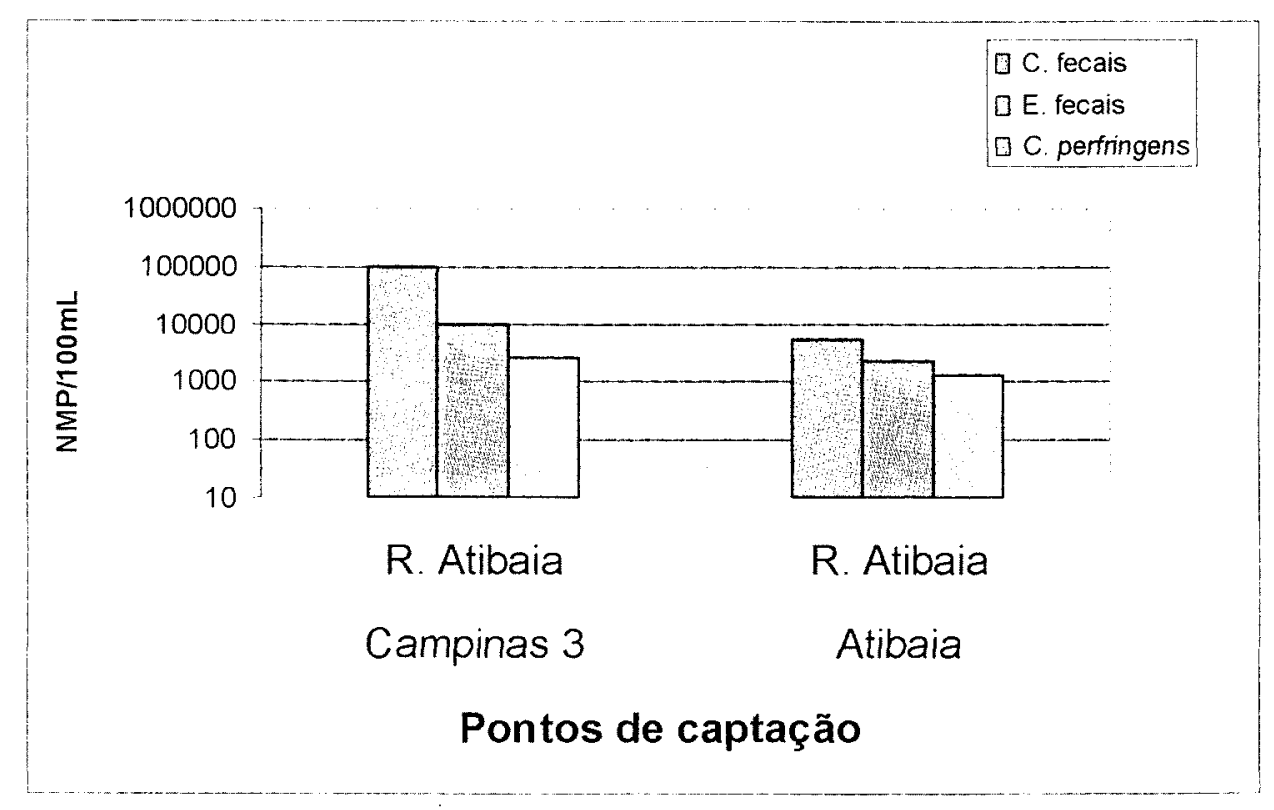

Figura 17 - Médias geométrica das concentrações de coliformes fecais, estreptococos fecais e C. perfringens em amostras coletadas nos pontos de captação do rio Atibaia (UGRHI 05) 


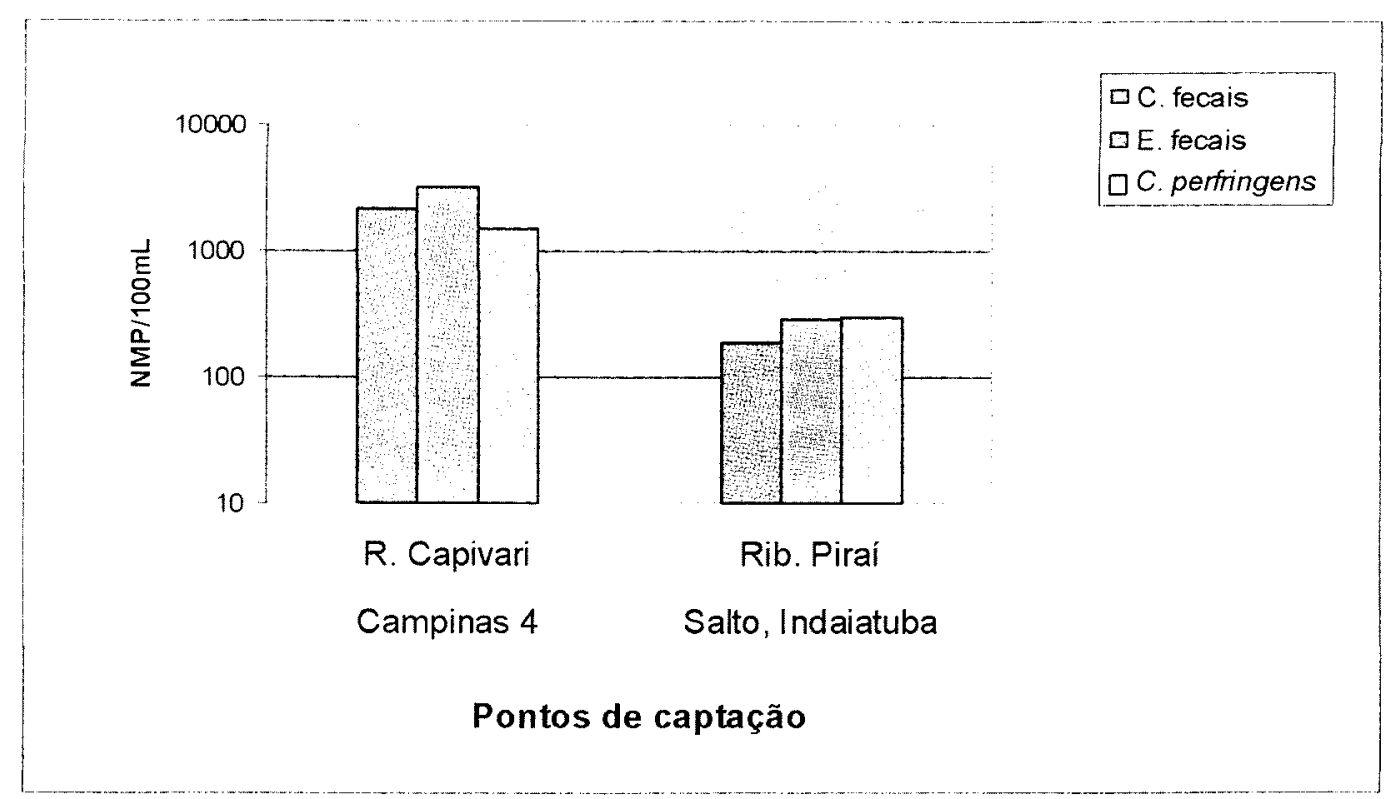

Figura 18 - Médias geométricas das concentrações de coliformes fecais, estreptococos fecais e $C$. perfingens em amostras coletadas nos pontos de captação do rio Capivari e ribeirão Piraí (UGRHI 05).

\subsection{3 - UGRHI 06 - Alto Tietê}

\subsubsection{1 - Giardia sp e Cryptosporidium sp}

Foram observadas amostras positivas para Giardia sp em dois dos três pontos de captação da bacia do rio Tietê Alto, Cabeceiras. No reservatório Jundiaí, no canal de interligação com o reservatório Taiaçupeba, a Giardia sp foi detectada em 1 das 11 amostras coletadas. No ponto localizado no rio Tietê, na captação principal de Mogi das Cruzes, 27\% (3/11) das amostras revelaram a presença de Giardia sp em concentrações relativamente elevadas. No rio Taiaçupeba, a jusante do vertedouro, todas as amostras foram negativas O Cryplosporidium $\mathrm{sp}$ não foi detectado nesses locais. Esses resultados estão apresentados na Tabela 5. 
Os dois pontos do reservatório Billings (braço do Taquacetuba, reservatório Billings, na baia situada no final da rua Tomekichi lnouye e reservatório do rio Grande, próximo à rodovia Anchieta, junto à captação da SABESP) apresentaram resultados negativos para os protozoários. No ponto do reservatório Guarapiranga (reservatório do Guarapiranga, na captação da SABESP junto à casa de bombas) a Giardia sp e o Cryptosporidium sp foram detectados na amostra coletada em setembro de 1999 . Esses resultados podem ser observados na Tabela 6.

$\mathrm{Na}$ bacia do rio Cotia, os resultados foram bastante diferentes nos dois pontos estudados: no ponto localizado no reservatório das Graças, junto à captação na barragem das Graças, Cotia Alto, todas as amostras foram negativas para Giardia $\mathrm{sp}$ e Cryptosporidium sp. Entretanto, no ponto situado no rio Cotia, no canal de captação de águas da ETA do Cotia Baixo, a Giardia sp foi detectada em todas as amostragens, em concentrações superiores a 100 cistos/L em algumas ocasiões, mas o (ryptosporidium sp não foi detectado nessas amostras. Esses resultados podem ser observados na Tabela 7.

$\mathrm{Na}$ zona metropolitana da bacia do rio Tietê Alto, em dois dos três pontos avaliados a qualidade da água foi bastante boa levando-se em conta a baixa porcentagem de deteç̧ão dos protozoários. No reservatório Tanque Grande, junto à barragem do municipio de Guarulhos, todas as amostras foram negativas, enquanto que no reservatório do rio Juqueri, ponte Santa Inês, na rodovia que liga Mairiporã a Franco da Rocha, somente a Giardia sp foi detectada em 30\% (3/10) das amostras. Em contraste, no ribeirão dos Cristais, na captação da ETA de Cajamar, esse protozoário foi observado em $78 \%(7 / 9)$ das amostras, em concentrações relativamente elevadas em alguma delas. O Cryptosporidnum sp não foi detectado nesses locais. Os resultados das análises dos protozoários nesses pontos está apresentado na Tabela 8 
Tabela 5 - Resultados das análises de Giardia sp e Cryptosporidium sp nos pontos de captação da bacia do rio Tietê Alto - Cabeceiras (UGRHI 06).

\begin{tabular}{|c|c|c|c|}
\hline $\begin{array}{l}\text { Data de } \\
\text { Coleta }\end{array}$ & Local da Coleta & $\begin{array}{c}\text { Giardia } \mathrm{sp} \\
\text { (cistos/L) }\end{array}$ & $\begin{array}{c}\text { Cryptosporidium sp } \\
\text { (oocistos/L) }\end{array}$ \\
\hline $14 / 01 / 99$ & & $A$ & A \\
\hline $30 / 03 / 99$ & & A & $\mathrm{A}$ \\
\hline $19 / 05 / 99$ & & A & $A$ \\
\hline $01 / 07 / 99$ & Reservatório Jundiaí, no & A & A \\
\hline 09/09/99 & canal de interligação com & A & A \\
\hline $04 / 11 / 99$ & o reservatório Taiaçupeba & A & A \\
\hline $13 / 01 / 00$ & & A & A \\
\hline $30 / 03 / 00$ & & 3 & A \\
\hline $24 / 05 / 00$ & & A & A \\
\hline $26 / 07 / 00$ & $\cdot$ & A & A \\
\hline $26 / 09 / 00$ & & A & A \\
\hline $14 / 01 / 99$ & & $\bar{A}$ & $A$ \\
\hline $24 / 03 / 99$ & & A & A \\
\hline $19 / 05 / 99$ & & A & A \\
\hline $01 / 07 / 99$ & & A & A \\
\hline $09 / 09 / 99$ & Rio Taiaçupeba, a jusante & A & A \\
\hline $04 / 11 / 99$ & do vertedouro & A & $A$ \\
\hline $13 / 01 / 00$ & & A & A \\
\hline $30 / 03 / 00$ & & A & A \\
\hline $24 / 05 / 00$ & & A & A \\
\hline $26 / 07 / 00$ & & A & A \\
\hline $26 / 09 / 00$ & & A & A \\
\hline $14 / 01 / 99$ & & 68 & A \\
\hline 09/03/99 & & 93 & A \\
\hline $27 / 05 / 99$ & Rio Tietê, na captação & A & A \\
\hline $01 / 07 / 99$ & principal do municipio de & A & A \\
\hline $09 / 09 / 99$ & Mogi das Cruzes & 50 & A \\
\hline $04 / 11 / 99$ & & A & A \\
\hline $13 / 01 / 00$ & & A & A \\
\hline $27 / 03 / 00$ & & $\mathrm{~A}$ & A \\
\hline $25 / 05 / 00$ & & A & A \\
\hline $25 / 07 / 00$ & & A & A \\
\hline $21 / 09 / 00$ & & $\mathrm{~A}$ & A \\
\hline
\end{tabular}

A - ausente 
Tabela 6 - Resultados das análises de Giardia sp e Cryptosporidium sp nos pontos de captação da UGRHI 06 nos reservatórios Billings e Guarapiranga.

\begin{tabular}{|c|c|c|c|}
\hline $\begin{array}{l}\text { Data de } \\
\text { Coleta }\end{array}$ & Local da Coleta & $\begin{array}{c}\text { Giardia } \mathrm{sp} \\
(\text { cistos } / \mathrm{L})\end{array}$ & $\begin{array}{l}\text { Cryptosporidium } \mathrm{sp} \\
\text { (oocistos/L) }\end{array}$ \\
\hline $24 / 03 / 99$ & & A & $\bar{A}$ \\
\hline $12 / 05 / 99$ & & A & $\mathrm{A}$ \\
\hline $29 / 07 / 99$ & & $A$ & $A$ \\
\hline 29/09/99 & Braço do Taquacetuba, & A & $A$ \\
\hline $25 / 11 / 99$ & reservatório Billings, na baia & A & A \\
\hline $26 / 01 / 00$ & situada no final da rua & A & A \\
\hline $15 / 03 / 00$ & Tomekichi Inouye & A & A \\
\hline $03 / 05 / 00$ & & A & $A$ \\
\hline $05 / 07 / 00$ & & A & A \\
\hline $20 / 09 / 00$ & & A & $A$ \\
\hline $21 / 01 / 99$ & & A & $\mathrm{A}$ \\
\hline $10 / 03 / 99$ & & A & $A$ \\
\hline $12 / 05 / 99$ & & A & A \\
\hline $29 / 07 / 99$ & & A & $A$ \\
\hline $29 / 09 / 99$ & Reservatório do rio Grande, & A & $\mathrm{A}$ \\
\hline $25 / 11 / 99$ & próximo à rodovia Anchieta, & A & $\mathrm{A}$ \\
\hline $06 / 01 / 00$ & junto à captação da SABESP & A & A \\
\hline $15 / 03 / 00$ & & A & A \\
\hline $03 / 05 / 00$ & & A & A \\
\hline $05 / 07 / 00$ & & A & $\mathrm{A}$ \\
\hline $21 / 09 / 00$ & & A & A \\
\hline $27 / 01 / 99$ & & A & $\mathrm{A}$ \\
\hline $18 / 03 / 99$ & & A & A \\
\hline $26 / 05 / 99$ & & A & $A$ \\
\hline $21 / 07 / 99$ & Reservatorio do & A & A \\
\hline $15 / 09 / 99$ & Guarapiranga, na captação & 13 & 3 \\
\hline $23 / 11 / 99$ & da SABESP, junto à casa & A & A \\
\hline $05 / 01 / 00$ & de bombas & $\mathrm{A}$ & A \\
\hline $16 / 03 / 00$ & & A & A \\
\hline $17 / 05 / 00$ & & A & A \\
\hline $19 / 07 / 00$ & & A & A \\
\hline $20 / 09 / 00$ & & $A$ & A \\
\hline
\end{tabular}


Tabela 7 - Resultados das análises de Giardia sp e Cryptosporidium sp nos pontos de captação da bacia do rio Cotia (UGRHI 06).

\begin{tabular}{cccc}
\hline $\begin{array}{c}\text { Data de } \\
\text { Coleta }\end{array}$ & Local da Coleta & $\begin{array}{c}\text { Giardia sp } \\
\text { (cistos/L) }\end{array}$ & $\begin{array}{c}\text { Cryptosporidium sp } \\
\text { (oocistos/L) }\end{array}$ \\
\hline $28 / 01 / 99$ & & $\mathrm{~A}$ & $\mathrm{~A}$ \\
$18 / 03 / 99$ & $\mathrm{~A}$ & $\mathrm{~A}$ \\
$20 / 05 / 99$ & Reservatório das Graças, & $\mathrm{A}$ & $\mathrm{A}$ \\
$13 / 07 / 99$ & junto à captação na barragem & $\mathrm{A}$ & $\mathrm{A}$ \\
$23 / 09 / 99$ & das Graças, Cotia Alto & $\mathrm{A}$ & $\mathrm{A}$ \\
$25 / 11 / 99$ & & $\mathrm{~A}$ & $\mathrm{~A}$ \\
$12 / 01 / 00$ & & $\mathrm{~A}$ & $\mathrm{~A}$ \\
$21 / 03 / 00$ & & $\mathrm{~A}$ & $\mathrm{~A}$ \\
$17 / 05 / 00$ & & $\mathrm{~A}$ & $\mathrm{~A}$ \\
\hline $28 / 01 / 99$ & & 100 & $\mathrm{~A}$ \\
$18 / 03 / 99$ & & 35 & $\mathrm{~A}$ \\
$20 / 05 / 99$ & Rio Cotia, no canal de & 29 & $\mathrm{~A}$ \\
$13 / 07 / 99$ & captação de águas da ETA & 167 & $\mathrm{~A}$ \\
$23 / 09 / 99$ & do Cotia Baixo & 215 & $\mathrm{~A}$ \\
$25 / 11 / 99$ & & 73 & $\mathrm{~A}$ \\
$12 / 01 / 00$ & & 104 & $\mathrm{~A}$ \\
$21 / 03 / 00$ & & 85 & $\mathrm{~A}$ \\
$17 / 05 / 00$ & & 55 & $\mathrm{~A}$ \\
\hline
\end{tabular}

$A-$ ausente 
Tabela 8 - Resultados das análises de Giardia sp e Cryptosporidium sp nos pontos de captação da zona metropolitana da bacia do rio Tietê Alto.

\begin{tabular}{|c|c|c|c|}
\hline $\begin{array}{l}\text { Data de } \\
\text { Coleta }\end{array}$ & Local da Coleta & $\begin{array}{l}\text { Giardia } \mathrm{sp} \\
\text { (cistos/L) }\end{array}$ & $\begin{array}{c}\text { Cryptosporidium sp } \\
\text { (oocistos/L) }\end{array}$ \\
\hline $18 / 01 / 99$ & & A & $\mathrm{A}$ \\
\hline $11 / 03 / 99$ & & A & $A$ \\
\hline $13 / 05 / 99$ & & A & $A$ \\
\hline $22 / 07 / 99$ & Reservatório Tanque Grande, & A & A \\
\hline $16 / 09 / 99$ & junto à barragem, & A & A \\
\hline $18 / 11 / 99$ & no municipio de Guarulhos & A & A \\
\hline $27 / 01 / 00$ & & A & A \\
\hline $09 / 03 / 00$ & & A & A \\
\hline $30 / 05 / 00$ & & $A$ & A \\
\hline $19 / 09 / 00$ & & A & A \\
\hline $18 / 01 / 99$ & & A & A \\
\hline $11 / 03 / 99$ & & 3 & A \\
\hline $13 / 05 / 99$ & Reservatório do rio Juqueri, & 5 & A \\
\hline $22 / 07 / 99$ & ponte Santa Inês, na rodovia & A & A \\
\hline $16 / 09 / 99$ & que liga Mairiporã a & A & A \\
\hline $18 / 11 / 99$ & Franco da Rocha & 9 & A \\
\hline $27 / 01 / 00$ & & A & A \\
\hline $09 / 03 / 00$ & & A & A \\
\hline $30 / 05 / 00$ & & A & A \\
\hline $19 / 09 / 00$ & & A & A \\
\hline $18 / 01 / 99$ & & 5 & $A$ \\
\hline $11 / 03 / 99$ & & 48 & A \\
\hline $13 / 05 / 99$ & & 53 & A \\
\hline $22 / 07 / 99$ & Ribeirão dos Cristais & 20 & A \\
\hline $16 / 09 / 99$ & na captação da ETA de & 15 & $\mathrm{~A}$ \\
\hline $18 / 11 / 99$ & Cajamar & A & A \\
\hline $27 / 01 / 00$ & & A & A \\
\hline $09 / 03 / 00$ & & 30 & $\mathrm{~A}$ \\
\hline $30 / 05 / 00$ & & 40 & $\mathrm{~A}$ \\
\hline
\end{tabular}

A - ausente 


\subsubsection{2 - Coliformes Fecais, Estreptococos fecais e $C$. perfringens}

Os resultados dos indicadores de contaminação fecal nas pontos localizados na bacia do rio Tietê Alto - Cabeceiras foram coerentes com os resultados observados para os protozoários. Nas amostragens realizadas no reservatório Jundiai, no canal de interligação com o reservatório Taiaçupeba, as concentrações de coliformes fecais, estreptococos fecais e $C$. perfringens permaneceram baixas em todas as campanhas, - limite CONAMA para águas de classe 1, na qual se enquadra esse corpo d'água ( 200 coliformes fecais $/ 100 \mathrm{~mL}$ ) somente tendo sido superado na amostra coletada em janeiro de 2000. Nesse mês os dois outros indicadores também apresentaram densidades mais elevadas.

No rio Taiaçupeba, a jusante do vertedouro, os resultados foram similares, embora o valor de 200 coliformes fecais/100mL estabelecido pelo CONAMA para águas de classe 1 tenha sido ultrapassado em 3 das 11 amostragens realizadas. Os niveis de estreptococos fecais mantiveram-se proporcionais aos dos coliformes fecais, mas para o C perfringens foram observadas concentraçôes mais elevadas em algumas amostragens

Por outro lado, as concentrações dos indicadores apresentaram-se altas no rio Tietê, na captação principal de Mogi das Cruzes. O limite CONAMA de 1.000 coliformes fecais/100mL, estabelecido para águas de classe 2, foi obedecido em apenas 4 das 11 campanhas realizadas. As densidades de estreptococos fecais e $C$. perfringens foram proporcionais áquelas dos coliformes fecais em praticamente todas as coletas. As médias geométricas das concentrações desses indicadores nesses 3 pontos de captação estão apresentadas na Figura 19 


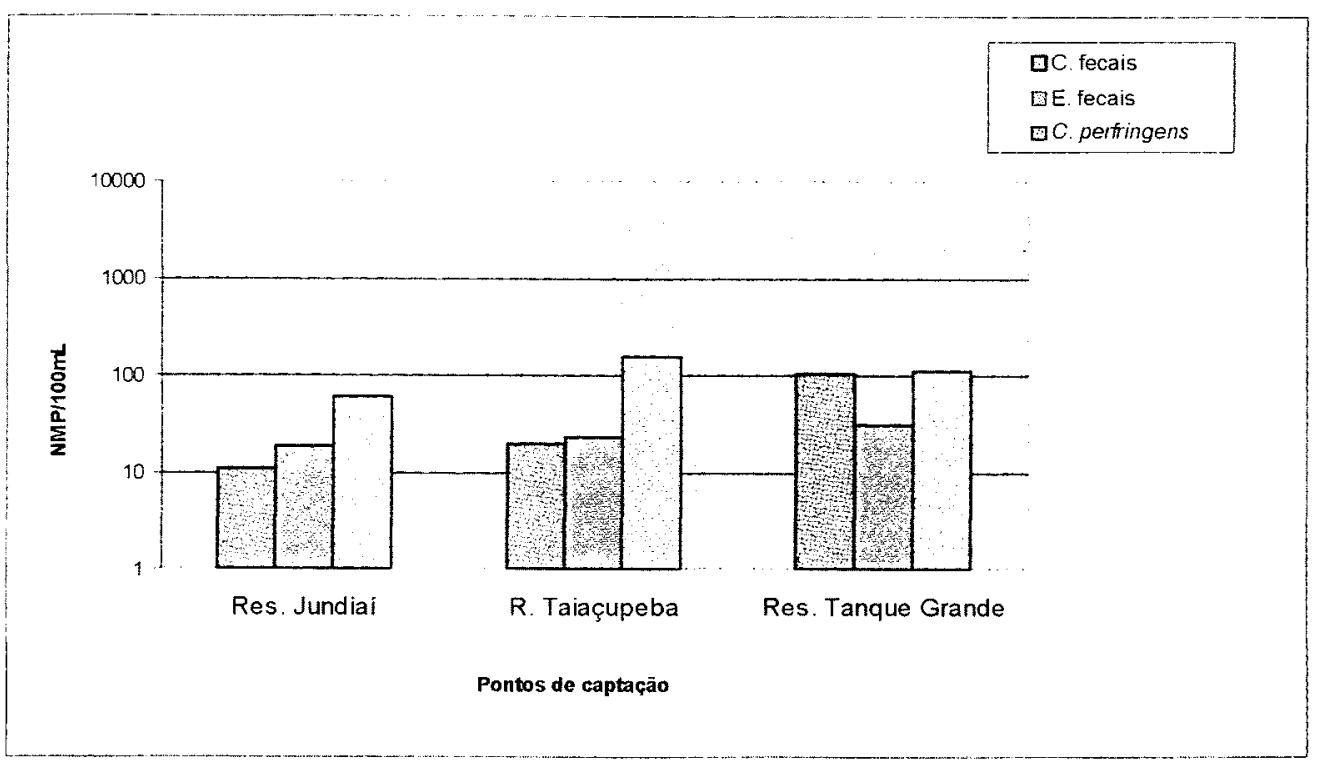

Figura 19 - Médias geométricas das concentrações de coliformes fecais, estreptococos fecais e C. perfringens em amostras coletadas nos pontos de captação localizados na bacia do rio Tietê Alto - cabeceiras (UGRHI 06).

Os pontos situados no reservatório Billings (braço do Taquacetuba, reservatório Billings, na baía situada no final da rua Tomekichi Inouye, e reservatório do rio Grande, próximo à rodovia Anchieta, junto à captação da SABESP) apresentaram excelente qualidade bacteriológica, com densidades muito baixas de coliformes fecais e estreptococos fecais e concentrações comparativamente mais elevadas de $C$. perfingens. Em nenhuma das amostragens realizadas foi superado o limite CONAMA de 200 coliformes fecais/100mL para águas de classe 1 na qual estão classificados esses corpos d'água. Quanto ao ponto localizado no reservatório do Guarapiranga, na captação da SABESP junto à casa de bombas, também enquadrado na classe 1 do CONAMA, somente foi verificado um valor maior que o limite de 200 coliformes fecais/100mL na amostragem realizada em janeiro de 2000 . As concentrações de estreptococos fecais também permaneceram baixas durante todo 0 período de estudo, mas as densidades de C. perfringens mostraram-se bem mais altas nesse ponto. Na Figura 20 estão representadas as médias geométricas das concentrações desses indicadores nesses locais. 


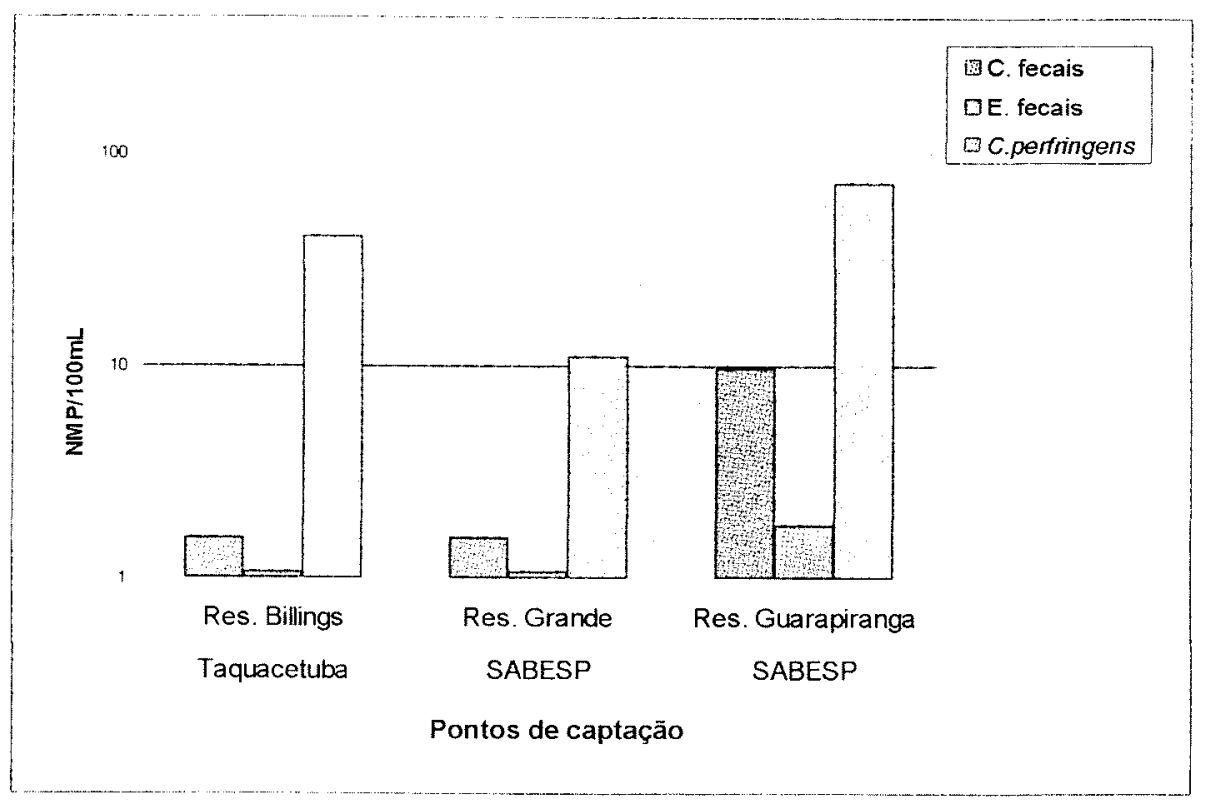

Figura 20 - Médias geométricas das concentrações de coliformes fecais, estreptococos fecais e $C$. perfingens em amostras coletadas nos pontos de captação dos reservatórios Billings e Guarapiranga (UGRHI 06).

$\mathrm{Na}$ bacia do rio Cotia, similarmente aos resultados das análises dos protozoários foi observada uma grande diferença na qualidade dos pontos amostrados, no que diz respeito aos indicadores de contaminação fecal. No reservatório das Graças, junto à captação, na barragem das Graças, Cotia Alto, as concentrações desses microrganismos foram extremamente baixas, tendo sido obedecido o limite CONAMA (classe $1-200$ coliformes fecais/100mL) em todas as coletas.

No rio Cotia, no canal de captação de águas da ETA do Cotia Baixo, em todas as amostragens foram verificadas concentrações muito altas dos três indicadores e o limite CONAMA (classe $3-4.000$ coliformes fecais/100mL) foi excedido sempre. As médias geométricas das densidades dessas bactérias para esses dois pontos podem ser observadas na Figura 21 


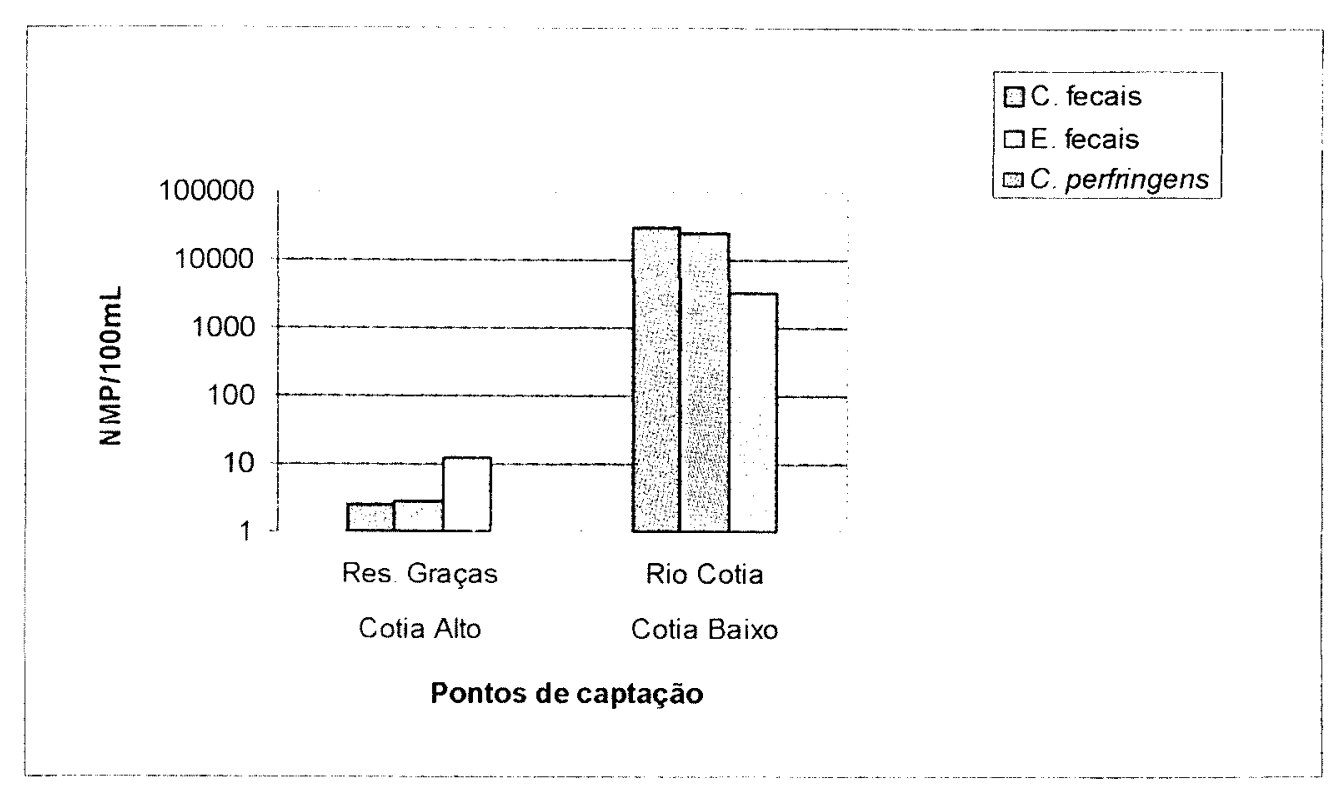

Figura 21 - Médias geométricas das concentrações de coliformes fecais, estreptococos fecais e $C$. perfringens em amostras coletadas nos pontos de captação do rio Cotia (UGRHI 06).

Quanto aos pontos localizados na zona metropolitana da bacia do Tietê Alto, foi observada boa qualidade bacteriológica, principalmente no ponto localizado no reservatório do rio Juqueri, ponte Santa Inês, na rodovia que liga Mairiporã a Franco da Rocha. Nas 10 amostras coletadas nesse local, o limite CONAMA de 200 coliformes fecais $/ 100 \mathrm{~mL}$ somente foi superado na amostragem realizada em março de 2000 . No $2^{\circ}$ ponto amostrado nessa bacia, reservatório do Tanque Grande, junto à barragem, no município de Guarulhos, verificou-se variação acentuada nas concentrações de estreptococos fecais e coliformes fecais. O limite CONAMA para esse reservatório (classe $1-200$ coliformes fecais/100mL) não foi obedecido nas amostragens de janeiro, março e maio de 1999, e em março de 2000. Em concordância com os resultados das análises parasitológicas, todos os indicadores bacterianos de contaminação fecal analisados apresentaram concentrações muito altas no ponto localizado no ribeirão dos Cristais, na captação da ETA de Cajamar, e o limite CONAMA (classe 3-4.000 coliformes fecais/ $100 \mathrm{~mL}$ ) somente foi obedecido 
nas coletas realizadas em maio e setembro de 1999. As médias geométricas das densidades desses indicadores nesses três pontos podem ser observadas na Figura 22

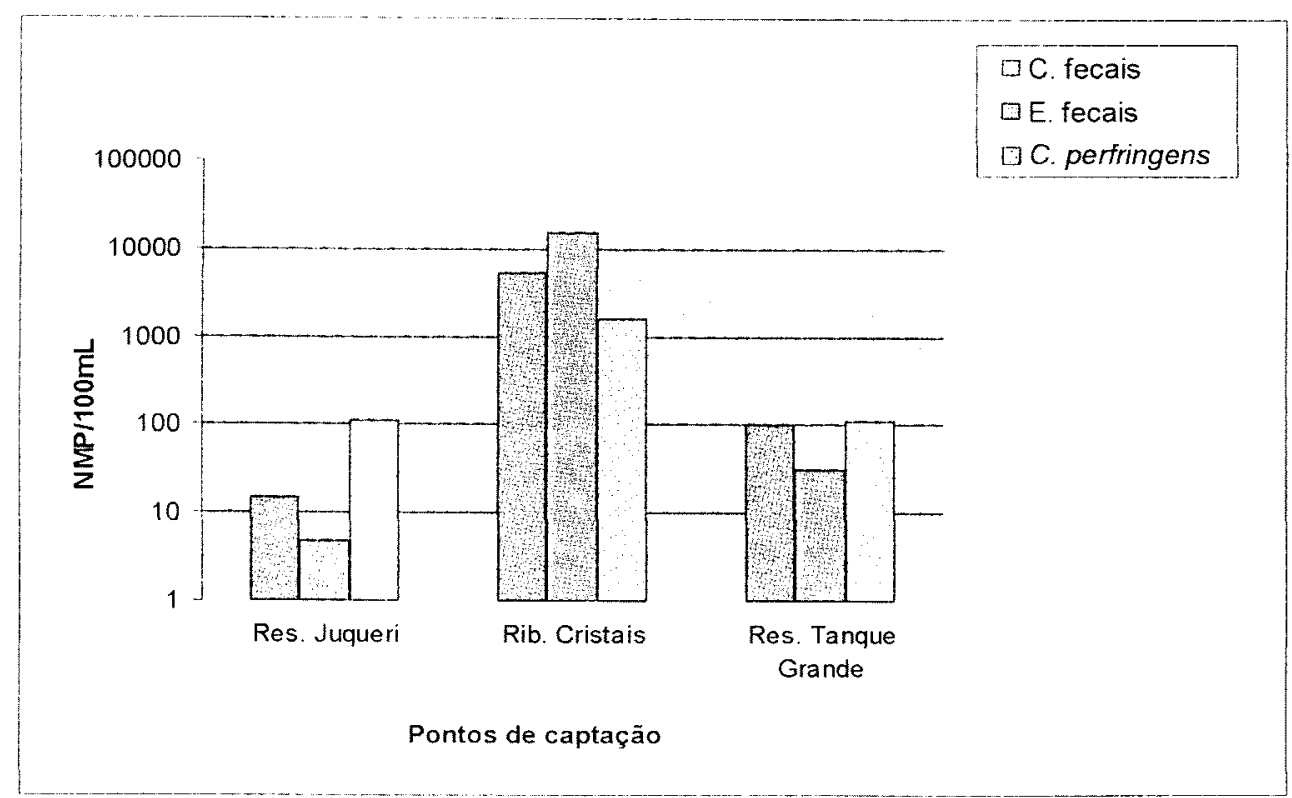

Figura 22 - Médias geométricas das concentrações de coliformes fecais, estreptococos fecais e C. perfiringens em amostras coletadas nos pontos de captação da zona metropolitana da bacia do Tietê Alto (UGRHI 06).

\subsection{4 - UGRHI 07 - Baixada Santista}

\subsubsection{1 - Giardia sp e Cryptosporidium sp}

A Criardia sp foi detectada em 20\% (2/10) das amostras analisadas nos dois pontos de captação da Baixada Santista (rio Cubatão, Ponte Preta, em frente à antiga ETA do rio Cubatão e reservatório do Capivari-Monos, junto à estação de recalque da SABESP). Apenas neste último local, numa das amostragens na qual a Giardia sp foi positiva, em maio de 1999, foi detectado o Cryptosporidium sp, na concentração de 20 oocistos/L. Esses resultados estão apresentados na Tabela 9 
Tabela 9 - Resultados da analise de Giardia sp e Cryptosporidium sp nos pontos de captação da UGRHI 07 - Baixada Santista.

\begin{tabular}{cccc}
\hline $\begin{array}{c}\text { Data de } \\
\text { Coleta }\end{array}$ & Local da Coleta & $\begin{array}{c}\text { Giardia sp } \\
\text { (cistos/L) }\end{array}$ & $\begin{array}{c}\text { Cryptosporidium sp } \\
\text { (oocistos/L) }\end{array}$ \\
\hline $12 / 01 / 99$ & $\mathrm{~A}$ & $\mathrm{~A}$ \\
$28 / 04 / 99$ & & 12 & $\mathrm{~A}$ \\
$23 / 06 / 99$ & Rio Cubatão, Ponte Preta & $\mathrm{A}$ & $\mathrm{A}$ \\
$18 / 08 / 99$ & em frente à antiga ETA & $\mathrm{A}$ & $\mathrm{A}$ \\
$18 / 10 / 99$ & do rio Cubatão & $\mathrm{A}$ & $\mathrm{A}$ \\
$15 / 12 / 99$ & & $\mathrm{~A}$ & $\mathrm{~A}$ \\
$23 / 02 / 00$ & & $\mathrm{~A}$ & $\mathrm{~A}$ \\
$06 / 04 / 00$ & & $\mathrm{~A}$ & $\mathrm{~A}$ \\
$02 / 06 / 00$ & & $\mathrm{~A}$ & $\mathrm{~A}$ \\
$09 / 08 / 00$ & & $\mathrm{~A}$ & $\mathrm{~A}$ \\
\hline $26 / 01 / 99$ & & $\mathrm{~A}$ & $\mathrm{~A}$ \\
$18 / 03 / 99$ & & 3 & $\mathrm{~A}$ \\
$26 / 05 / 99$ & Reservatório do- & $\mathrm{A}$ & 20 \\
$21 / 07 / 99$ & Capivari-Monos, junto à & $\mathrm{A}$ & $\mathrm{A}$ \\
$15 / 09 / 99$ & estação de recalque & $\mathrm{A}$ & $\mathrm{A}$ \\
$17 / 11 / 99$ & da S ABESP & $\mathrm{A}$ & $\mathrm{A}$ \\
$05 / 01 / 00$ & & $\mathrm{~A}$ & $\mathrm{~A}$ \\
$16 / 03 / 00$ & & & $\mathrm{~A}$ \\
$09 / 05 / 00$ & & & \\
$19 / 07 / 00$ & & & $\mathrm{~A}$ \\
\hline
\end{tabular}

$\mathrm{A}$-ausente 


\subsubsection{2 - Coliformes Fecais, Estreptococos fecais e C. perfringens}

As concentrações de coliformes fecais e estreptococos fecais apresentaram variação acentuada $(2-8.000 \mathrm{NMP} / 100 \mathrm{~mL}$ e $2-5.000 \mathrm{NMP} / 100 \mathrm{~mL}$, respectivamente) no rio Cubatão, Ponte Preta, em frente à antiga ETA do rio Cubatão, mantendo-se proporcionais em praticamente todas as campanhas. O limite CONAMA para águas de classe 2 ( 1.000 coliformes fecais/ $100 \mathrm{~mL}$ ) foi superado em 4 das 10 amostragens. Os niveis de C. perfrigens permaneceram constantes. No reservatório do Capivari-Monos, junto à estação de recalque da SABESP, foram verificadas menores flutuações nas concentrações dos coliformes fecais e estreptococos fecais, baixas durante quase todo o período de estudo. O limite CONAMA de 200 coliformes fecais/100mL foi superado em duas amostragens. Como no outro ponto de captação, os níveis de C. perfringens permaneceram constantes. As médias geométricas desses resultados estão apresentadas na Figura 23.

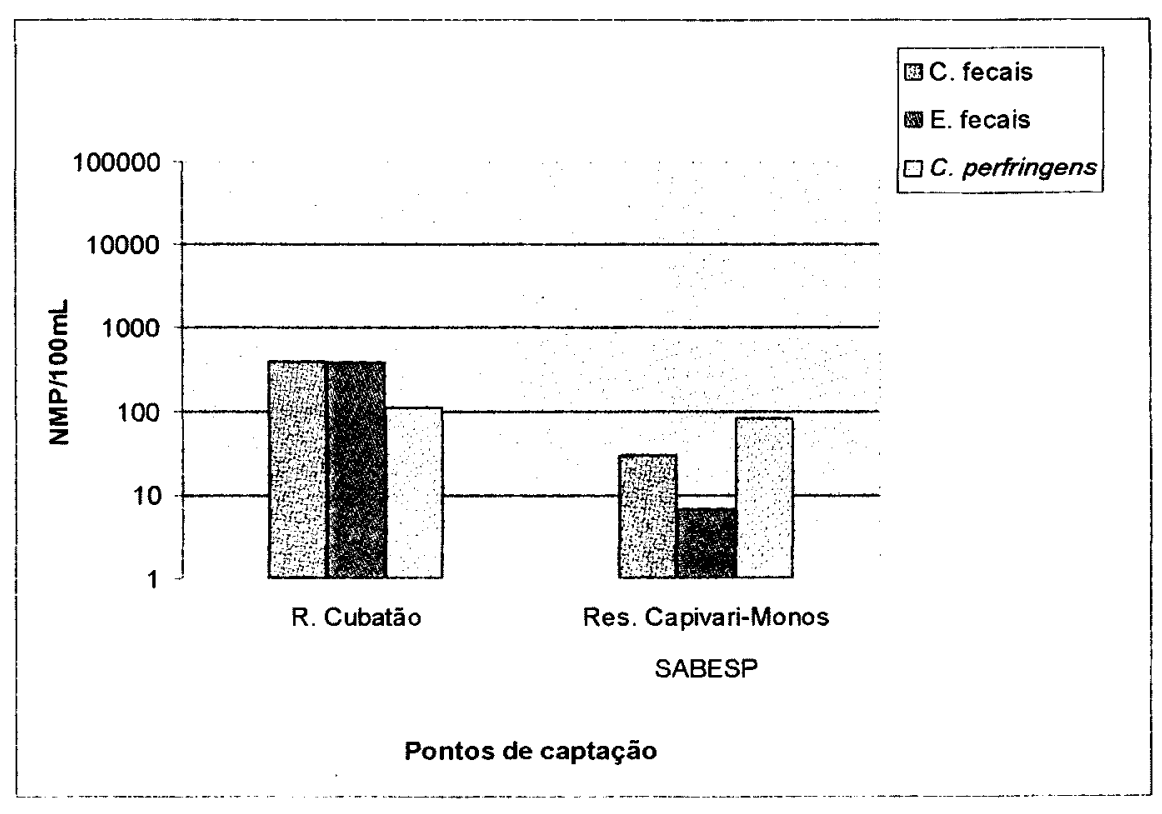

Figura 23 - Médias geométricas das concentrações de coliformes fecais, estreptococos fecais e C. perfringens em amostras coletadas nos pontos de captação da UGRHI 07 - Baixada Santista. 


\subsection{5 - UGRHI 09 - Mogi-Guaçú}

\subsubsection{1 - Giardia sp e Cryptosporidium sp}

No ponto avaliado nessa bacia, rio Mogi-Guaçú, junto à captação da ETA da Academia de Força Aerea de Pirassununga, a Giardia sp foi isolada em 50\% (5/10) das amostras coletadas, em concentrações relativamente baixas. O Cryptospordium sp foi detectado na amostra coletada em abril de 1999, quando a Giardia sp também foi positiva. Esses resultados estão apresentados na Tabela 10.

Tabela 10 - Resultados das análises de Giardia sp e Cryptosporidium sp no ponto de captação da UGRHI 09 -Mogi-Guaçú.

\begin{tabular}{cccc}
\hline Data de & Local da Coleta & Giardia sp & Cryptosporidium $\mathrm{sp}$ \\
\hline $04 / 01 / 99$ & & $\mathrm{~A}$ & $\mathrm{~A}$ \\
$01 / 04 / 99$ & & 31 & 2 \\
$08 / 06 / 99$ & & 4 & $\mathrm{~A}$ \\
$03 / 08 / 99$ & Rio Mogi-Guaçú, junto à & 4 & $\mathrm{~A}$ \\
$26 / 01 / 99$ & captação da ETA da & $\mathrm{A}$ & $\mathrm{A}$ \\
$07 / 12 / 99$ & Academia de Força Aérea de & 6 & $\mathrm{~A}$ \\
$01 / 02 / 00$ & Pirassununga & $\mathrm{A}$ & $\mathrm{A}$ \\
$04 / 04 / 00$ & & 15 & $\mathrm{~A}$ \\
$28 / 06 / 00$ & & $\mathrm{~A}$ & $\mathrm{~A}$ \\
$29 / 08 / 00$ & & $\mathrm{~A}$ & $\mathrm{~A}$ \\
\hline
\end{tabular}

\subsubsection{2 - Coliformes Fecais, Estreptococos fecais e Clostridium perfringens}

O limite CONAMA para águas de classe 2 (1.000 coliformes fecais/100mL) foi ultrapassado em 3 das 10 amostragens realizadas. As densidades de estreptococos fecais e C pertringens apresentaram-se similares àquelas dos coliformes fecais, em praticamente todas as coletas. As médias geométricas desses resultados podem ser observadas na Figura 24. 


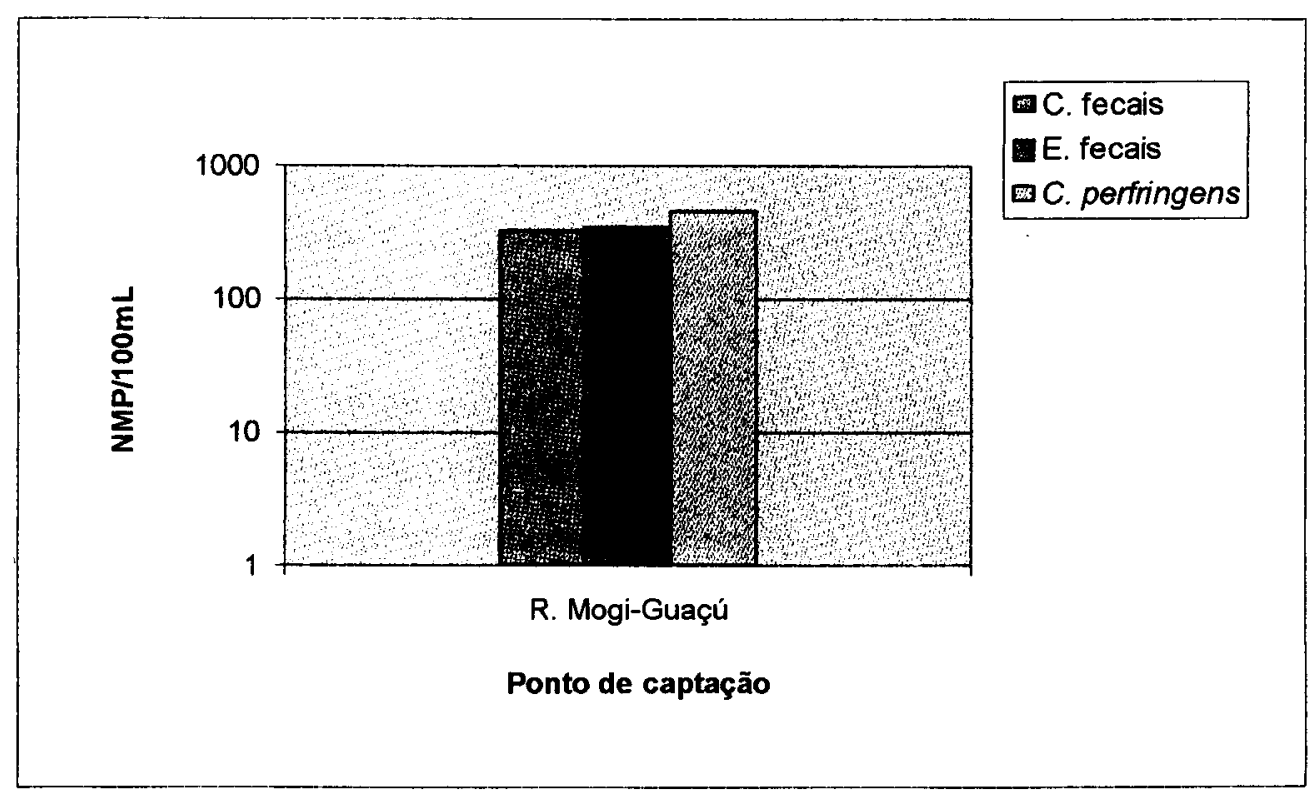

Figura 24 - Médias geométricas das concentrações de coliformes fecais, estreptococos fecais e C perfringens em amostras coletadas nos pontos de captação da UGRHI 09 - Mogi-Guaçú.

\subsection{6 - UGRHI 10 - Sorocaba/Médio Tietê}

\subsubsection{1 - Giardia sp e Cryptosporidium sp}

Nenhum dos protozoários foi detectado nas 11 amostragens realizadas no ponto de captação dessa bacia (reservatório de Ituapararanga, próximo à barragem, na estrada que liga Ibiúna a Votorantim). Esses resultados podem ser observados na Tabela 11. 
Tabela 11 - Resultados das análises de Giardia sp e Cryptosporidium sp no ponto de captação da UGRHI 10 - Sorocaba/Médio Tietê.

\begin{tabular}{cccc}
\hline $\begin{array}{c}\text { Data de } \\
\text { Coleta }\end{array}$ & Local da Coleta & $\begin{array}{c}\text { Giardia sp } \\
\text { (cistos/L) }\end{array}$ & $\begin{array}{c}\text { Cryptosporidium sp } \\
\text { (oocistos/L) }\end{array}$ \\
\hline $27 / 01 / 99$ & $\mathrm{~A}$ & $\mathrm{~A}$ \\
$02 / 03 / 99$ & $\mathrm{~A}$ & $\mathrm{~A}$ \\
$04 / 05 / 99$ & & $\mathrm{~A}$ & $\mathrm{~A}$ \\
$28 / 07 / 99$ & Reservatório de Itupararanga & $\mathrm{A}$ & $\mathrm{A}$ \\
$08 / 09 / 99$ & próximo à barragem, na & $\mathrm{A}$ & $\mathrm{A}$ \\
$09 / 11 / 99$ & estrada que liga Ibiúna & $\mathrm{A}$ & $\mathrm{A}$ \\
$04 / 01 / 00$ & a Votorantim & $\mathrm{A}$ & $\mathrm{A}$ \\
$14 / 03 / 00$ & & $\mathrm{~A}$ & $\mathrm{~A}$ \\
$02 / 05 / 00$ & & $\mathrm{~A}$ & $\mathrm{~A}$ \\
$18 / 07 / 00$ & & $\mathrm{~A}$ & $\mathrm{~A}$ \\
$19 / 09 / 00$ & & $\mathrm{~A}$ & $\mathrm{~A}$ \\
\hline $\mathrm{A}=$ ausente & & &
\end{tabular}

\subsubsection{2 - Coliformes Fecais, Estreptococos Fecais e C. perfringens}

De acordo com os resultados das análises dos indicadores de contaminação fecal, estava excelente a qualidade bacteriológica do ponto de captação dessa bacia (reservatorio Itupararanga, próximo à barragem, na estrada que liga Ibiúna a Votorantim). As concentrações coliformes fecais e estreptococos fecais somente atingiram valores próximos a $100 \mathrm{NMP} / 100 \mathrm{~mL}$, em duas amostragens, e, assim o limite CONAMA de 1.000 coliformes fecais $/ 100 \mathrm{~mL}$, para águas de classe 2 , na qual se enquadra esse reservatório não foi ultrapassado em nenhuma das amostragens realizadas. As médias geometricas das concentrações desses indicadores podem ser observadas na Figura 25. 


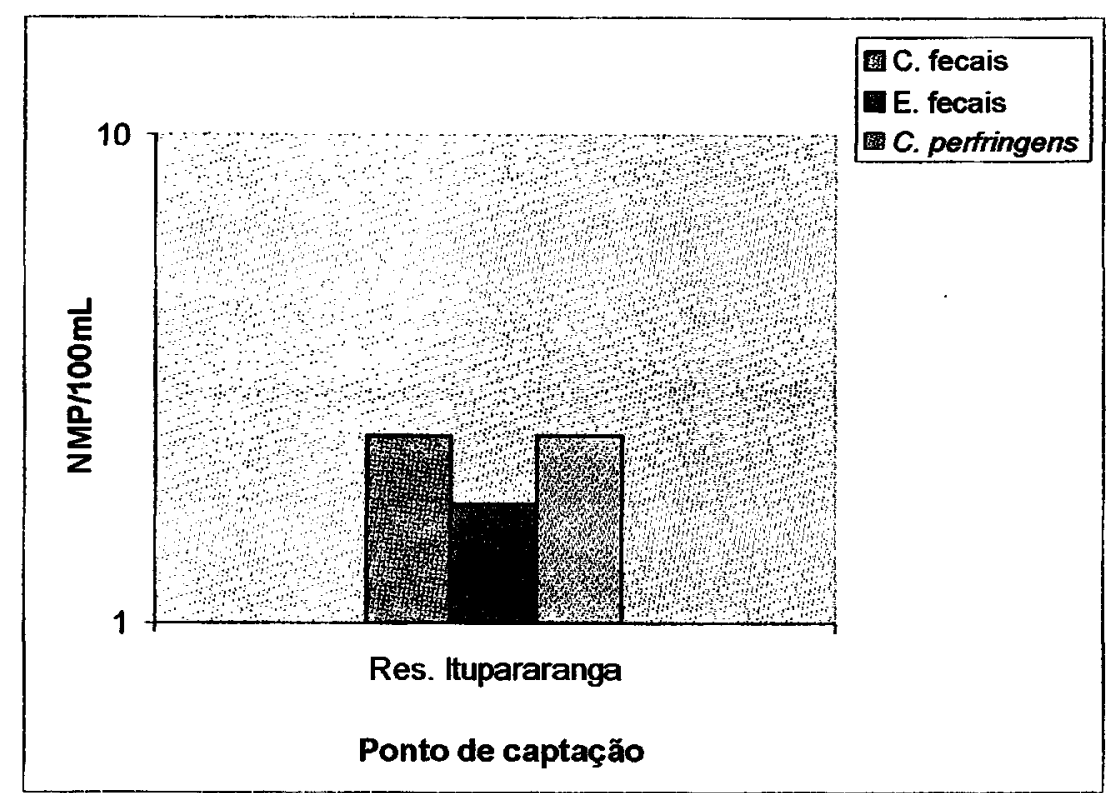

Figura 25 - Médias geométricas das concentrações de coliformes fecais, estreptococos fecais e $C$. perfiringens em amostras coletadas no ponto de captação da UGRHI 10 - Sorocaba/Médio Tietê.

\subsection{7 - UGRHI 15 - Turvo Grande}

\subsubsection{1 - Giardia sp e Cryptosporidium sp}

No ponto de captação avaliado nessa bacia (reservatório do rio Preto, na captação de São José do Rio Preto), somente a Giardia sp foi detectada, em concentrações muito baixas ( 1 cisto/L), em uma das 9 amostragens realizadas. Esses resultados podem ser observados na Tabela 12

\subsubsection{2 - Coliformes Fecais, Estreptococos Fecais e C. perfringens}

Nas 9 amostragens realizadas, foram observadas concentrações elevadas dos indicadores, principalmente dos coliformes fecais, no reservatório do rio Preto, na captação da ETA de São José do Rio Preto. O limite CONAMA de 1.000 coliformes fecais $/ 100 \mathrm{~mL}$, para águas de classe 2 , foi obedecido apenas no mês de abril de 2000 . 
As médias geométricas das concentrações dos três indicadores nesses pontos estão apresentadas na Figura 26

Tabela 12 - Resultados das análises de Giardia sp e Cryptosporidium sp no ponto de captação da UGRHI 15 - Turvo Grande

\begin{tabular}{cccc}
$\begin{array}{c}\text { Data de } \\
\text { Coleta }\end{array}$ & Local da Coleta & $\begin{array}{c}\text { Giardia sp } \\
\text { (cistos/L) }\end{array}$ & $\begin{array}{c}\text { Cryptosporidium sp } \\
\text { (oocistos/L) }\end{array}$ \\
\hline $04 / 01 / 99$ & & $\mathrm{~A}$ & $\mathrm{~A}$ \\
$15 / 06 / 99$ & & $\mathrm{~A}$ & $\mathrm{~A}$ \\
$10 / 08 / 99$ & Reservatório do Rio Preto, & $\mathrm{A}$ & $\mathrm{A}$ \\
$26 / 10 / 99$ & na captação da ETA de & $\mathrm{A}$ & $\mathrm{A}$ \\
$14 / 12 / 99$ & São José do Rio Preto & $\mathrm{A}$ & $\mathrm{A}$ \\
$09 / 02 / 00$ & & $\mathrm{~A}$ & $\mathrm{~A}$ \\
$06 / 04 / 00$ & & $\mathrm{~A}$ & $\mathrm{~A}$ \\
$13 / 06 / 00$ & & $\mathrm{~A}$ & $\mathrm{~A}$ \\
$16 / 08 / 00$ & & $\mathrm{~A}$ & $\mathrm{~A}$ \\
\hline
\end{tabular}

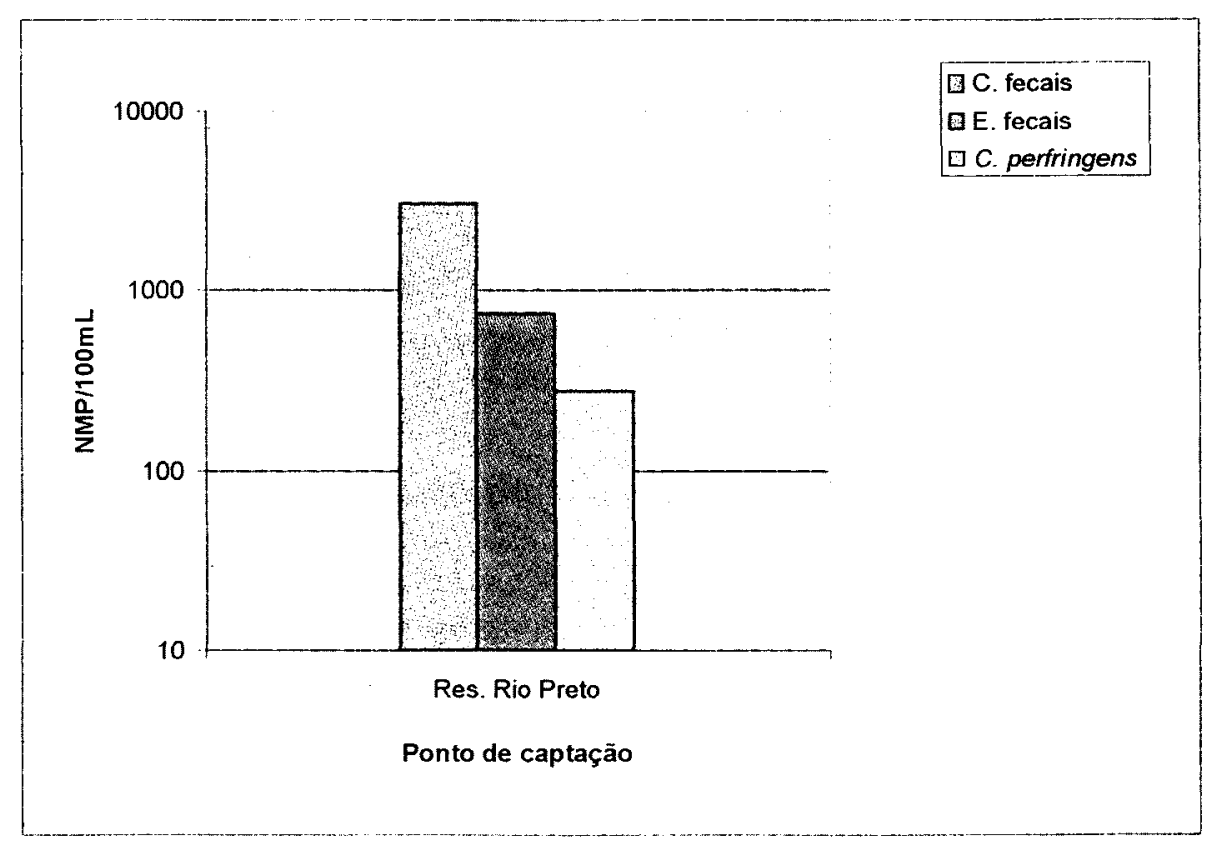

Figura 26 - Médias geométricas das concentrações de coliformes fecais, estreptococos fecais e C. perfingensem amostras coletadas no ponto de captação da UGRHI 15 - Turvo Grande. 


\subsection{8 - UGRHI 17 - Médio Paranapanema}

\subsubsection{1 - Giardia sp e Cryptosporidium sp}

O ponto de captação da UGRHI 17 está localizado no rio Pardo, ponte na rodovia Raposo Tavares, km 381. Nesse local, a Giardia sp e o Cryptosporidium sp foram isolados em $50 \%(5 / 10)$ e $10 \%(1 / 10)$ das amostras analisadas, respectivamente. Esses resultados estão apresentados na Tabela 13

Tabela 13 - Resultados das análises de Giardia sp e Cryptosporidium sp no ponto de captação da UGRHI 17 - Médio Paranapanema

\begin{tabular}{cccc}
\hline $\begin{array}{c}\text { Data de } \\
\text { Coleta }\end{array}$ & Local da Coleta & $\begin{array}{c}\text { Giardia sp } \\
\text { (cistos/L) }\end{array}$ & $\begin{array}{c}\text { Cryptosporidium sp } \\
\text { (oocistos/L) }\end{array}$ \\
\hline $05 / 01 / 99$ & $\mathrm{~A}$ & $\mathrm{~A}$ \\
$27 / 04 / 99$ & & 40 & $\mathrm{~A}$ \\
$09 / 06 / 99$ & & 13 & 7 \\
$04 / 08 / 99$ & Rio Pardo, na rodovia & 20 & $\mathrm{~A}$ \\
$13 / 10 / 99$ & Raposo Tavares, km 381 & $\mathrm{A}$ & $\mathrm{A}$ \\
$15 / 12 / 99$ & & $\mathrm{~A}$ & $\mathrm{~A}$ \\
$15 / 02 / 00$ & & $\mathrm{~A}$ & $\mathrm{~A}$ \\
$11 / 04 / 00$ & & 10 & $\mathrm{~A}$ \\
$27 / 06 / 00$ & 37 & $\mathrm{~A}$ \\
$24 / 08 / 00$ & $\mathrm{~A}$ & $\mathrm{~A}$ \\
\hline $\mathrm{A}=$ ausente & & &
\end{tabular}

\subsubsection{2 - Coliformes fecais, estreptococos fecais e $C$. perfringens}

Foram observadas concentrações muito elevadas dos três indicadores de contaminação fecal durante todo o periodo de estudo. O limite CONAMA (classe 2 1.000 coliformes fecais $/ 100 \mathrm{~mL}$ foi superado nas 10 amostragens realizadas. Os estreptococos fecais e o C. perfringens apresentaram densidades proporcionais àquelas dos coliformes fecais na maior parte das campanhas. As médias geométricas das concentrações dessas bacterias pode ser observada na Figura 27 


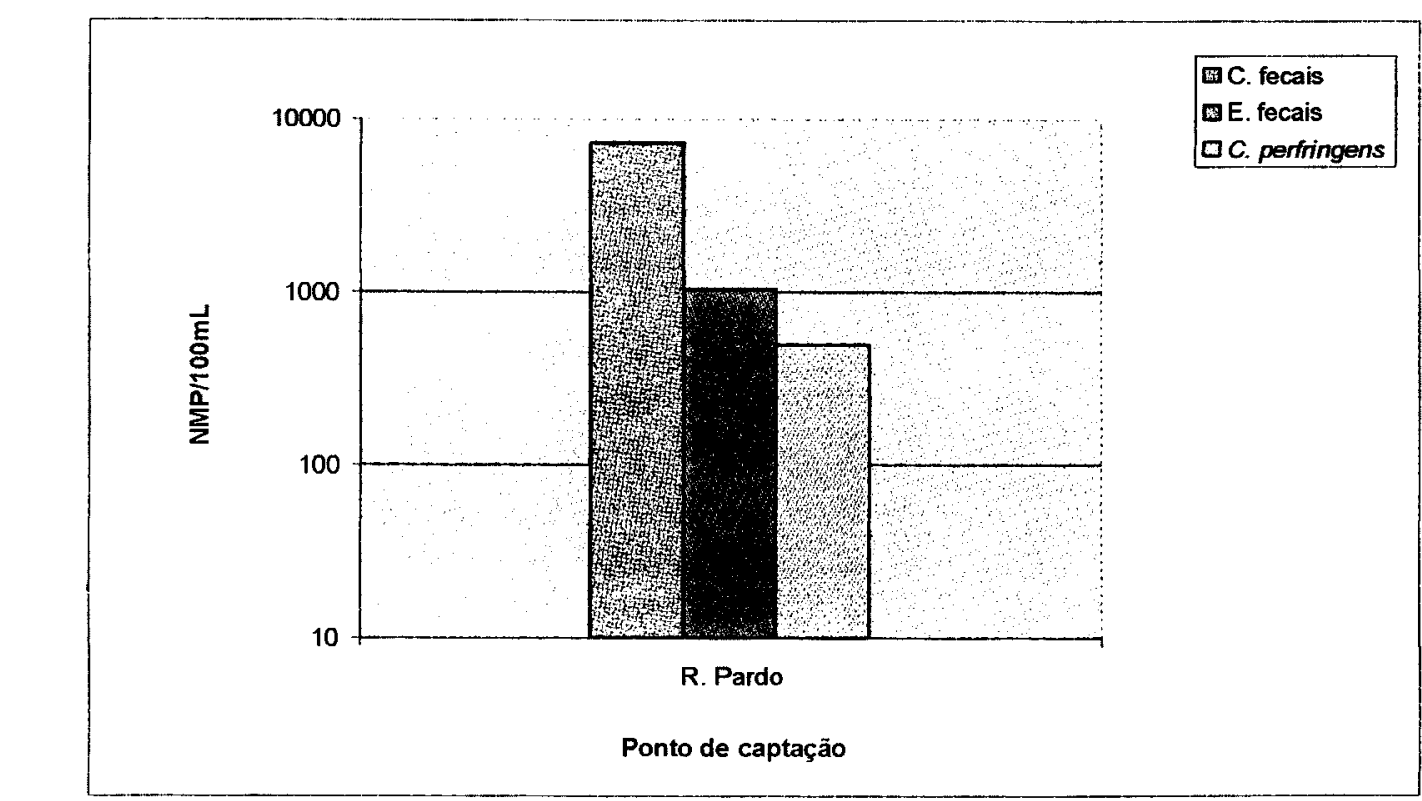

Figura 27 - Médias geométricas das concentrações de coliformes fecais, estreptococos fecais e C' perfringens em amostras coletadas no ponto de captação da UGRHI 17 - Médio Paranapanema.

\subsection{9 - UGRHI 21 - Peixe}

\subsubsection{1 - Giardia sp e Cryptosporidium sp}

No ponto de captação estudado nessa bacia (rio do Peixe, ponte na rodovia que liga Marilia a Assis), 50\% (5/10) das amostras coletadas foram positivas para Giardia sp, em alguns casos em concentrações relativamente elevadas (35 cistos/L), enquanto que o cryplosporidium sp foi detectado apenas na amostragem realizada em junho de 1999, na concentração de 2 oocistos/L. Esses resultados estão apresentados na Tabela 14 . 
Tabela 14 - Resultados das análises de Giardia sp e Cryptosporidium sp no ponto de captação da UGRHI 21 - Peixe.

\begin{tabular}{cccc}
\hline $\begin{array}{c}\text { Data de } \\
\text { Coleta }\end{array}$ & Local da Coleta & $\begin{array}{c}\text { Giardia sp } \\
\text { (cistos/L) }\end{array}$ & $\begin{array}{c}\text { Cryptosporidium } \mathrm{sp} \\
\text { (oocistos/L) }\end{array}$ \\
\hline $05 / 01 / 99$ & & $\mathrm{~A}$ & $\mathrm{~A}$ \\
$27 / 04 / 99$ & A & $\mathrm{A}$ \\
$09 / 06 / 99$ & Rio do Peixe, ponte na & 35 & 2 \\
$04 / 08 / 99$ & rodovia que liga & 25 & $\mathrm{~A}$ \\
$13 / 10 / 99$ & Marilia a Assis & 5 & $\mathrm{~A}$ \\
$15 / 12 / 99$ & & $\mathrm{~A}$ & $\mathrm{~A}$ \\
$15 / 02 / 00$ & & $\mathrm{~A}$ & $\mathrm{~A}$ \\
$11 / 04 / 00$ & & 27 & $\mathrm{~A}$ \\
$27 / 06 / 00$ & & 20 & $\mathrm{~A}$ \\
$24 / 08 / 00$ & & $\mathrm{~A}$ & $\mathrm{~A}$ \\
\hline
\end{tabular}

\subsubsection{2 - Coliformes Fecais, Estreptococos Fecais e C. perfringens}

Concentrações muito elevadas dos indicadores foram detectadas no ponto de captação situado nessa bacia (rio do Peixe, ponte na rodovia que liga Marília a Assis). As densidades dos coliformes fecais atingiram $10^{4} \mathrm{NMP} / 100 \mathrm{~mL}$ em várias amostragens, e o limite CONAMA para esse local (classe $2-1.000$ coliformes fecais/ $100 \mathrm{~mL}$ ) somente foi obedecido em agosto de 2000 , quando foram observados valores muito baixos para essas bactérias ( $3 \mathrm{NMP} / 100 \mathrm{~mL}$ ). Os estreptococos fecais tambem atingiram niveis de $10^{4} \mathrm{NMP} / 100 \mathrm{~mL}$ em várias coletas. As médias geométricas das concentrações dessas bactérias estão apresentadas na Figura 28 


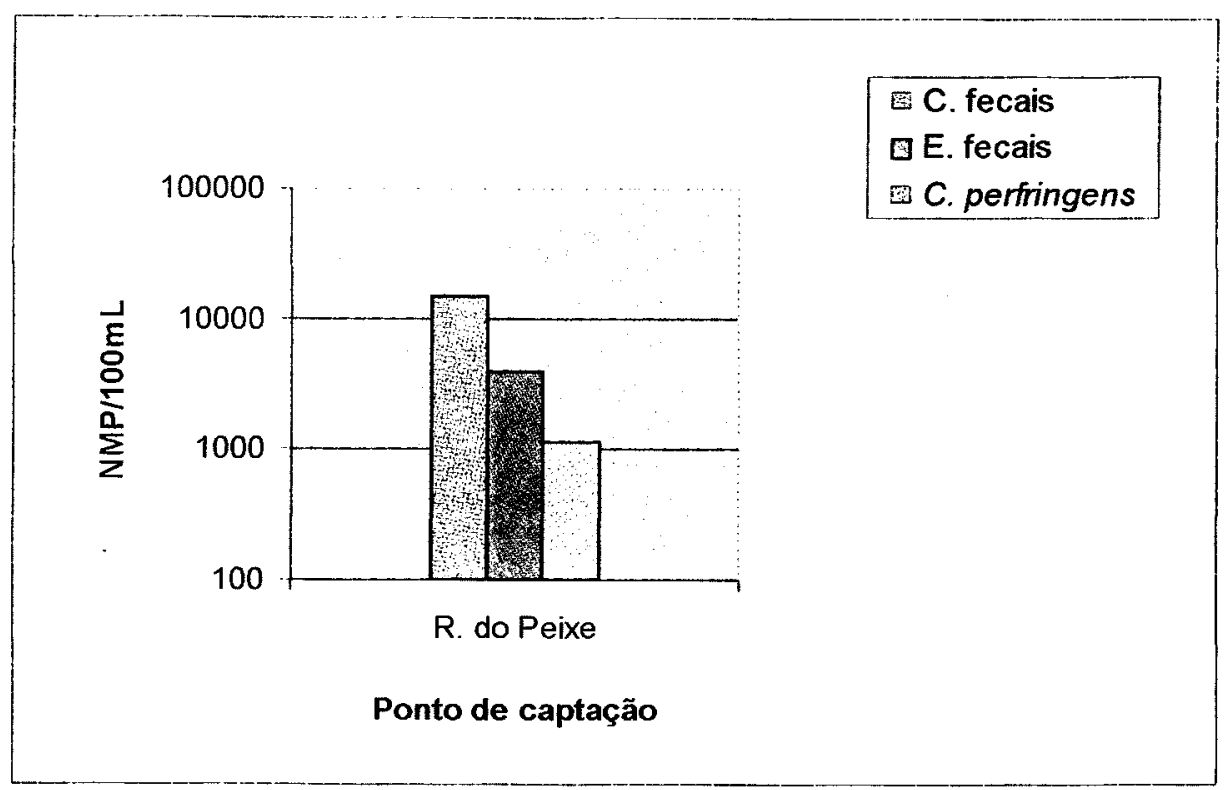

Figura 28 - Médias geométricas das concentrações de coliformes fecais, estreptococos fecais e ('. perfiringens em amostras coletadas no ponto de captação da UGRHI 21 - Peixe.

\subsubsection{0 - UGRHI 22 - Pontal do Paranapanema}

\subsubsection{1 - Giardia sp e Cryptosporidium sp}

Nenhum dos protozoários foi detectado nas 9 amostragens realizadas no ponto de captação dessa bacia (rio Paraná, ponte na rodovia que liga Presidente Epitáceo a Bataguaçú). Esses resultados estão apresentados na Tabela 15

\subsubsection{2 - Coliformes Fecais, Estreptococos Fecais e C.perfringens}

Em concordância com os resultados das análises de Giardic sp e Cryptosporidium sp, observou-se boa qualidade bacteriológica no ponto de captação dessa bacia (rio Paraná, ponte na rodovia que liga Presidente Epitáceo a Bataguçú), uma vez que as concentrações de coliformes fecais, estreptococos fecais e $C$. perfringens permaneceram baixas durante todo o período de estudo. O limite CONAMA, que é de 1.000 coliformes fecais $/ 100 \mathrm{~mL}$ para esse rio (classe 2) somente foi excedido nas 
coletas realizadas nos meses de junho e dezembro de 1999. As médias geométricas desses resultados estão apresentadas na Figura 29

Tabela 15 - Resultados das anál ises de Giardia sp e Cryptosporidium sp no ponto de captação da UGRHI 22 - Pontal do Paranapanema.

\begin{tabular}{cccc}
$\begin{array}{c}\text { Data de } \\
\text { Coleta }\end{array}$ & Local da Coleta & $\begin{array}{c}\text { Giardiasp } \\
\text { (cistos/L) }\end{array}$ & $\begin{array}{c}\text { Cryptosporidium sp } \\
\text { (oocistos/L) }\end{array}$ \\
\hline $26 / 01 / 99$ & & $\mathrm{~A}$ & $\mathrm{~A}$ \\
$07 / 04 / 99$ & A & $\mathrm{A}$ \\
$30 / 06 / 99$ & Rio Paraná, ponte na & $\mathrm{A}$ & $\mathrm{A}$ \\
$26 / 10 / 99$ & rodovia que liga & $\mathrm{A}$ & $\mathrm{A}$ \\
$14 / 12 / 99$ & Presidente Epitáceo a & $\mathrm{A}$ & $\mathrm{A}$ \\
$09 / 02 / 00$ & Bataguaçú & $\mathrm{A}$ & $\mathrm{A}$ \\
$14 / 06 / 00$ & & $\mathrm{~A}$ & $\mathrm{~A}$ \\
$14 / 04 / 00$ & & $\mathrm{~A}$ & $\mathrm{~A}$ \\
$02 / 08 / 00$ & & $\mathrm{~A}$ & $\mathrm{~A}$ \\
\hline
\end{tabular}

$\mathrm{A}=$ ausente

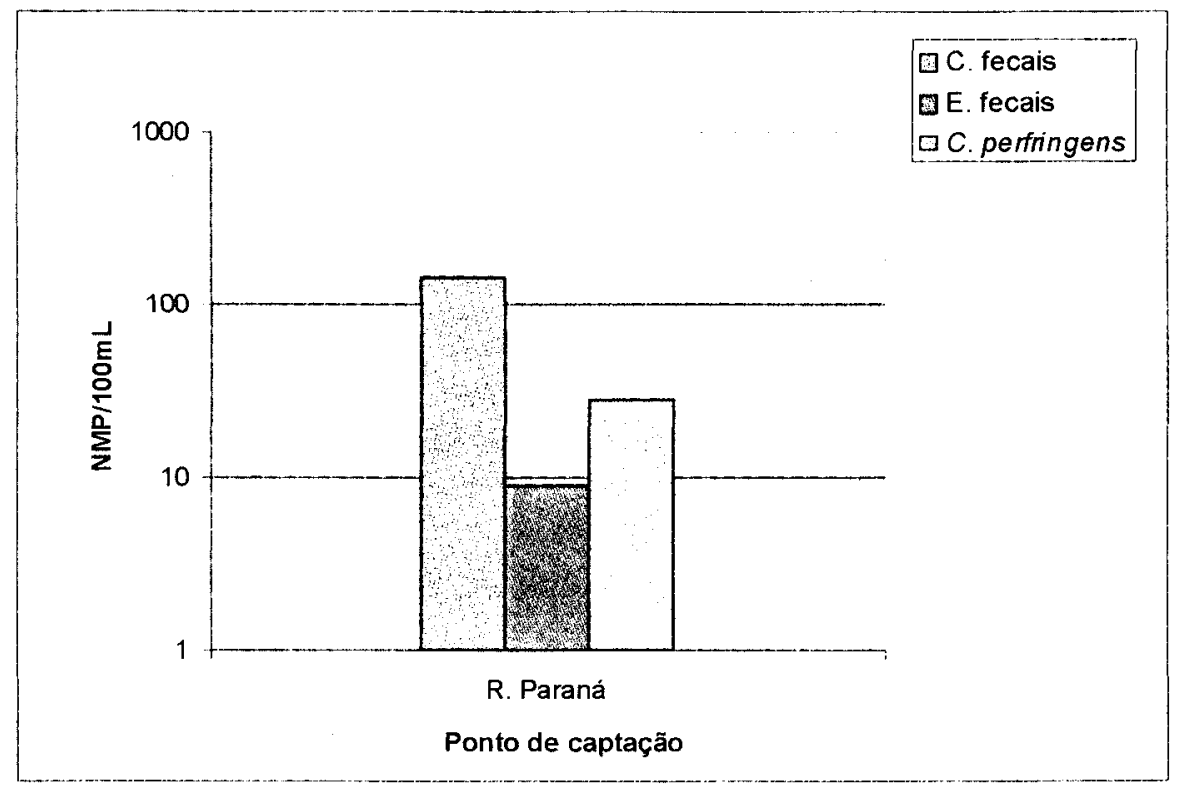

Figura 29 - Médias geométricas das concentrações de coliformes fecais, estreptococos fecais e $C$. perfringens em amostras coletadas no ponto de captação da UGRHI 22 - Pontal do Paranapanema. 
5.5 - Resultados da Correlação de Postos de Spearman entre as Concentrações de Giardia sp e as Bactérias Indicadoras de Contaminação Fecal, Coliformes Fecais, Estreptococos Fecais e $C$. perfringens

\subsection{1 - Correlação de Postos de Spearman para a Totalidade das Amostras Analisadas}

Os coeficientes de correlação de postos de Spearman ( $R$ ) e respectivos valores de $t$ e $\mathrm{P}$, calculados para os resultados das análises de Giardia sp, coliformes fecais, estreptococos fecais e $C$. perfringens de 278 amostras coletadas nas 10 UGRHIs, estão apresentados na Tabela 16.

Tabela 16 - Coeficientes de correlação de postos de Spearman (R), valores de te $P$ para os resultados das análises de Giardia sp e cada bactéria indicadora de contaminação fecal de 278 amostras.

\begin{tabular}{cccc}
\hline Microrganismos & $\mathrm{R}$ & $\mathrm{t}$ & $\mathrm{P}$ \\
\hline Giardia sp e coliformes fecais & 0,5246 & 10,24 & $<0,0001$ \\
Giardia sp e estreptococos fecais & 0,4873 & 9,27 & $<0,0001$ \\
Giardia sp e ('. perfringens & 0,4308 & 7,93 & $<0,0001$ \\
\hline
\end{tabular}

\subsection{2 - Correlação de Postos de Spearman em cada UGRHI}

\subsection{1 - UGRHI 02 - Paraíba do Sul}

Os coeficientes de correlação de postos de Spearman (R), valores de t e $P$ para os resultados das análises de Giardia $\mathrm{sp}$, coliformes fecais, estreptococos fecais e $C$. perfringens de 26 amostras coletadas em 3 pontos de captação da UGRHI 02 Paraiba do Sul, estão apresentados na Tabela 17. 
Tabela 17 - Coeficientes de correlação de postos de Spearman (R), valores de t e P para os resultados de análises de Giardia sp e cada bactéria indicadora de contaminação fecal de 26 amostras da UGRHI 02.

\begin{tabular}{cccc}
\hline Microrganismo & $\mathrm{R}$ & $\mathrm{t}$ & $\mathrm{P}$ \\
\hline Giardia sp e coliformes fecais & 0,6385 & 4,06 & $<0,001$ \\
Giardia sp e estreptococos fecais & 0,4454 & 2,44 & 0,023 \\
Giardia sp e C. perfringens & 0,3416 & 1,78 & $0,088^{*}$ \\
\hline
\end{tabular}

* não significativo

\subsubsection{2 - UGRHI 05 - Piracicaba, Capivari, Jundiaí}

Os coeficientes de correlação de postos de Spearman ( $R$ ), valores de t e $P$ para os resultados das análises de (ilardia $\mathrm{sp}$, coliformes fecais, estreptococos fecais e $C_{\text {. }}$ perfiringens de 61 amostras coletadas em 6 pontos de captação da UGRHI 05 Piracicaba, Capivari, Jundiai, estão apresentados na Tabela 18

Tabela 18 - Coeficientes de correlação de postos de Spearman (R), valores de t e $P$ para os resultados de análises de Giardia $\mathrm{sp}$ e cada bactéria indicadora de contaminação fecal de 61 amostras da UGRHI 05

\begin{tabular}{cccc}
\hline Microrganismo & $\mathrm{R}$ & $\mathrm{t}$ & $\mathrm{P}$ \\
\hline Giardia sp e coliformes fecais & 0,4203 & 3,56 & $<0.001$ \\
Giardia sp e estreptococos fecais & 0,2592 & 2,06 & 0,0437 \\
Giardia sp e C. perfringens & 0,2878 & 2,31 & 0,0245 \\
\hline
\end{tabular}

\subsubsection{3 - UGRHI 06 - Alto Tietê}

Os coeficientes de correlação de postos de Spearman ( $R$ ), valores de te $P$ para os resultados das análises de Giardia $\mathrm{sp}$, coliformes fecais, estreptococos fecais e $C$. perfringens de 112 amostras coletadas em 11 pontos de captação da UGRHI 06 Alto Tietê, estão apresentados na Tabela 19 
Tabela 19 - Coeficientes de correlação de postos de Spearman (R), valores de t e $P$ para os resultados de análises de Giardia sp e cada bactéria indicadora de contaminação fecal de 112 amostras da UGRHI 06.

\begin{tabular}{cccc}
\hline Microrganismo & $\mathrm{R}$ & $\mathrm{t}$ & $\mathrm{P}$ \\
\hline Giardia sp e coliformes fecais & 0,6148 & 8,17 & $<0,001$ \\
Giardia sp e estreptococos fecais & 0,5666 & 7,21 & $<0,001$ \\
Giardia sp e C. pertringens & 0,5175 & 7,30 & $<0,001$ \\
\hline
\end{tabular}

\subsubsection{4 - UGRHI 07 - Baixada Santista}

Os coeficientes de correlação de postos de Spearman (R), valores de t e $P$ para os resultados das análises de Giardia $\mathrm{sp}$, coliformes fecais, estreptococos fecais e $C$. perfringens de 20 amostras coletadas em 2 pontos de captação da UGRHI 07 Baixada Santista, estão apresentados na Tabela 20.

Tabela 20 - Coeficientes de correlação de postos de Spearman (R), valores de te $P$ para os resultados de análises de Giardia sp e cada bactéria indicadora de contaminação fecal de 20 amostras da UGRHI 07

\begin{tabular}{cccc}
\hline Microrganismo & $\mathrm{R}$ & $\mathrm{t}$ & $\mathrm{P}$ \\
\hline Giardia sp e coliformes fecais & 0,0436 & 0,18 & $0,8551^{*}$ \\
Giardia sp e estreptococos fecais & 0,1225 & 0,52 & $0,6067^{*}$ \\
Giardia sp e C. perfringens & $-0,1364$ & $-0,59$ & $0,5606^{*}$ \\
\hline
\end{tabular}

* Não-signilicativo

\subsubsection{5 - UGRHI 09 - Mogi-Guaçú}

Os coeficientes de correlação de postos de Spearman (R), valores de t e $P$ para os resultados das análises de Giardia $\mathrm{sp}$, coliformes fecais, estreptococos fecais e $C$. perfringens de 10 amostras coletadas em 1 ponto de captação da UGRHI 09 -MogiGuaçú, estão apresentados na Tabela 21 . 
Tabela 21 - Coeficientes de correlação de postos de Spearman (R), valores de t e $P$ para os resultados de análises de Giardia sp e cada bactéria indicadora de contaminação fecal de 10 amostras da UGRHI 09.

\begin{tabular}{cccc}
\hline Microrganismo & $\mathrm{R}$ & $\mathrm{t}$ & $\mathrm{P}$ \\
\hline Giardia sp e coliformes fecais & n.a. & - & - \\
Giardia sp e estreptococos fecais & 0,0358 & 0,10 & $0,9216^{*}$ \\
Giardia sp e C. perfringens & 0,0521 & 0,15 & $0,8864^{*}$ \\
\hline
\end{tabular}

n.a. = calculo não aplicavel: *não-signiticativo

\subsubsection{6 - UGRHI 10 - Sorocaba/Médio Tietê}

Não foi possivel o cálculo do coeficiente de correlação de postos de Spearman para os resultados das análises das 10 amostras coletadas em 1 ponto de captação da UGRHI 10 - Sorocaba/Médio Tietê

\subsubsection{7 - UGRHI 15 - Turvo Grande}

Os coeficientes de correlação de postos de Spearman (R), valores de t e P para os resultados das análises de Criardia $\mathrm{sp}$, coliformes fecais, estreptococos fecais e $C$. perfringens de 10 amostras coletadas em 1 ponto de captação da UGRHI 15 -Turvo Grande, estão apresentados na Tabela 22.

Tabela 22 - Coeficientes de correlação de postos de Spearman (R), valores de t e P para os resultados de análises de Giardia sp e cada bactéria indicadora de contaminação fecal de 10 amostras da UGRHI 15.

\begin{tabular}{cccc}
\hline Microrganismo & $\mathrm{R}$ & $\mathrm{t}$ & $\mathrm{P}$ \\
\hline Giardia sp e coliformes fecais & $-0,4215$ & $-1,20$ & $0,2698^{*}$ \\
Giardia sp e estreptococos fecais & 0,4107 & 1,19 & $0,2720^{*}$ \\
Giardia sp e C. perfringens & $-0,2738$ & $-0,75$ & $0,4758^{*}$ \\
\hline
\end{tabular}

*não-signiticativo 


\subsubsection{8 - UGRHI 17 - Médio Paranapanema}

Os coeficientes de correlação de postos de Spearman (R), valores de t e $P$ para os resultados das analises de Giardia $\mathrm{sp}$, coliformes fecais, estreptococos fecais e $C$. perfringens de 10 amostras coletadas em 1 ponto de captação da UGRHI 17 -Médio Paranapanema estão apresentados na Tabela 23.

Tabela 23 - Coeficientes de correlação de postos de Spearman (R), valores de t e P para os resultados de análises de Giardia sp e cada bactéria indicadora de contaminação fecal de 10 amostras da UGRHI 17.

\begin{tabular}{cccc}
\hline Microrganismo & $\mathrm{R}$ & $\mathrm{t}$ & $\mathrm{P}$ \\
\hline Giardia sp e coliformes fecais & 0,1362 & 0,39 & $0,7075^{*}$ \\
Giardia sp e estreptococos fecais & $-0,1112$ & $-0,32$ & $0,7596^{*}$ \\
Giardia sp e ('. perfingens & $-0,3242$ & $-0,97$ & $0,3607^{*}$ \\
\hline
\end{tabular}

*não-signiticativo

\subsubsection{9 - UGRHI 21 - Peixe}

Os coeficientes de correlação de postos de Spearman $(R)$, valores de t e P para os resultados das análises de Giardia $\mathrm{sp}$, coliformes fecais, estreptococos fecais e $C$. perfringens de 10 amostras coletadas em 1 ponto de captação da UGRHI 21 -Peixe, estão apresentados na Tabela 24

Tabela 24 - Coeficientes de correlação de postos de Spearman (R), valores de t e $\mathrm{P}$ para os resultados de análises de Giardia sp e cada bactéria indicadora de contaminação fecal de 10 amostras da UGRHI 21 .

\begin{tabular}{cccc}
\hline Mierorganismo & $\mathrm{R}$ & $\mathrm{t}$ & $\mathrm{P}$ \\
\hline Giardia sp e coliformes fecais & 0,1102 & 0,31 & $0,7617^{*}$ \\
Giardia sp e estreptococos fecais & $-0,5187$ & $-1,71$ & $0,1245^{*}$ \\
Giardia sp e C. perfringens & $-0,6744$ & $-2,58$ & 0,0324 \\
\hline
\end{tabular}

*não-significativo 


\subsubsection{0 - UGRHI 22 - Pontal do Paranapanema}

Não foi possivel o cálculo do coeficiente de correlação de postos de Spearman para os resultados das análises das 10 amostras coletadas em 1 ponto de captação da UGRHI 22 - Pontal do Paranapanema. 


\section{6 - DISCUSSÃO DOS RESULTADOS}

\section{1 - Resultados Globais das Análises de Giardia sp e Cryptosporidium sp}

Foram baixas as porcentagens globais de positividade para a Giardia sp (27\%) nos 28 pontos de captação das 10 UGRHIs estudadas (Figura 2), em comparação aos resultados relatados na literatura. Levando-se em conta o número de amostras positivas em cada ponto de captação (Figura 3), uma vez que a maior parte dos trabalhos restringe suas avaliações a apenas um, ou a alguns corpos d'água situados numa bacia hidrográfica, nossos resultados também são mais baixos, a exceção de alguns pontos de captação nos quais esses valores foram bem mais elevados. Essa divergência com relação à maior parte dos estudos realizados no Brasil e no exterior é ainda maior considerando-se a porcentagem de amostras positivas para o Cryptosporidium $\mathrm{sp} \mathrm{(2,5 \%} \mathrm{-} \mathrm{Figura} 2)$

Quanto às concentrações de Giardia sp, na maior parte dos pontos de captação, foram obtidos valores máximos inferiores a 100 cistos/L (Figura 4). Com exceção de alguns corpos d'água, nos quais foram registradas densidades extremamente elevadas desse protozoário, nossos resultados são similares àqueles relatados na literatura para águas superficiais. $\mathrm{O}$ mesmo pode ser dito com relação ao Cryptosporidium $\mathrm{sp}$, cujo valor máximo obtido nessa avaliação foi de 20 oocistos/L, no reservatório Capivari-Monos, junto à estação de recalque da SABESP (UGRHI 07 - Baixada Santista). Deve-se assinalar entretanto, que as faixas de concentração relatadas na literatura para ambos protozoários são bastante amplas.

Diferentes autores avaliando a presença desses protozoários em águas superficiais obtiveram frequência muito mais elevada de resultados positivos para a Giardia sp e principalmente para o Cryptosporidium sp. ROSE et al 1988 analisaram as concentrações desses protozoários em 39 amostras de um rio, situado na região oeste dos Estados Unidos, cujas águas seriam futuramente utilizadas para captação. A Giardia e o Cryptosporidium foram detectados em 20 e 12 das amostras, respectivamente, e as concentrações de oocistos foram cerca de 10 vezes superiores às concentrações dos 
cistos. Assim, as densidades de Giardia variaram de 0 a 2,22 cistos/L, enquanto que para o Cryptosporidium esses valores foram de 0 a 22 oocistos/L. Deve-se citar que os autores atribuem a origem desses protozoários à contaminação animal predominantemente.

Numa avaliação dos protozoários em 66 amostras provenientes de águas superficiais utilizadas para captação em 14 estados americanos e 1 província canadense, LECHEVALIER et al. 1991 verificaram que a Giardia e Cryptosporidium spp estavam presentes em $81 \%$ e $87 \%$ das amostras analisadas, respectivamente, e que as densidades de Cryptosporidium eram 1,5 vezes mais elevadas que as de Giardia. As médias geométricas das concentrações de Giardia spp (detectável) foram de 2,77 cistos/L, variando de 0.04 a 66 cistos/L, e para o (ryptosporidium spp, esses resultados foram de 2,70 oocistos/L níveis máximos e mínimos variando de 0,07 a 484 oocistos/L.

LECHEV ALIER e NORTON 1992 estudando amostras de águas brutas de turbidez alta, média e baixa, provenientes de três ETAs, localizadas nos Estados Unidos e Canadá, observaram porcentagens de positividade de $50 \%, 80 \%$ e $20 \%$ para a Giardia e de $100 \%, 70 \%$ e $70 \%$, respectivamente, para o Cryptospc ridium. No que diz respeito às densidades dos protozoários, os valores mínimos e máximos foram de 1,13 - 31,1;0,14 64,2 e 2,16 - 3,76 cistos/L de Giardia, nas amostras de turbidez alta, média e baixa, respectivamente. Quanto ao Cryptosporidium $\mathrm{sp}$, os autores obtiveram resultados de $0,82-71,9 ; 0,42-5,1$ e $0,77-8,7$ oocistos $/ L$.

Ampliando uma avaliação realizada anteriormente (LECHEVALIER et al. 1991), LECHEVALIER e NORTON 1995 compilaram os resultados das análises dos protozoários de 262 amostras de águas superficiais utilizadas para captação em 72 ETAs localizadas em 15 estados americanos e 2 provincias canadenses. Foi verificada uma porcentagem de $45 \%$ de amostras positivas para Giardia e $51,5 \%$ de amostras positivas para o Cryptosporidium . A média geométrica de Giardia (detectável) foi de 2,0 cistos/L $(0,02-43,8$ cistos/L), e para o Cryptosporidium foram obtidos valores de 2,4 oocistos $/ \mathrm{L}$ $(0,065-65,1$ oocistos/L). Os autores discutem os motivos pelos quais as porcentagens de positividade para os protozoários foram inferiores àquelas obtidas no estudo anterior, propondo quatro explicações para esse fato: o estudo original poderia ter identificado 
incorretamente os organismos, a técnica de análise do estudo atual teria sido menos eficiente na detecção dos organismos, as densidades dos protozoários teriam sofrido uma variação e o resultado real seria uma média dos dois estudos, e, finalmente, a ocorrência de Giardia e Cryptosporidium teriam diminuido nos últimos quatro anos. Os autores concluem pela última explicação, citando vários dados de outros trabalhos para fundamentar essa teoria

No Brasil, na cidade de Araras, no estado de São Paulo, foram analisadas 12 amostras de águas superficiais, incluindo-se pontos de captação de água para a cidade e pontos sob a influência de lançamento de efluentes domésticos. A Giardia e o Cryptosporidium foram detectados, respectivamente, em $8(66,7 \%)$ e $9(64,4 \%)$ das amostras (DIAS JÚNIOR. 1999).

FRANCO et al. 2001 analisaram esses protozoários na região de Campinas, no estado de São Paulo: Giardia e Cryptosporidim foram detectados em todas as amostras coletadas no Rio Atibaia, em concentrações máximas de 95,0 cistos/0,5L e 60,8 oocistos $/ 0,5 \mathrm{~L}$.

Podem ainda ser citados vários outros autores que encontraram porcentagens bem mais elevadas desses organismos em águas superficiais (STATES et al. 1997, ZUCKERMANN et al. 1997, KARANIS et al. 1998, HSU et al. 1999, HASHIMOTO et al. 2001 e THURMAN et al. 1998). Nas avaliações realizadas por esses pesquisadores, as densidades de Giardia sp e Cryptosporidium sp variaram entre valores minimos e máximos de $0,05-70$ cistos $/ L$ e $0,04-125$ oocistos/L, respectivamente

Por outro lado, em algumas outras pesquisas foram relatadas menores porcentagens de amostras positivas para a Giardia sp e Cryptosporidium $\mathrm{sp}$, com valores mais próximos aos relatados nesse trabalho. WALLIS et al. 1996 analisaram 1173 amostras de águas superficiais provenientes de várias municipalidades do Canadá, observando porcentagens de positividade de $20,9 \%$ para cistos de Giardia e de $4,5 \%$ para oocistos de Cryptosporidium. A concentração mais elevada de Giardia (230 cistos $/ \mathrm{L}$ ) foi verificada numa comunidade ao norte de Ontário, durante um surto da doença. Para o Cryptosporidium, as densidades das amostras positivas foram quase sempre menores que 0,5 oocistos/ $100 \mathrm{~L}$ Os autores comentam a baixa frequiência de resultados positivos para 
esse último, as dificuldades no reconhecimento exato dos oocistos, e na interferência das algas, que apresentam reação cruzada com os anticorpos para o Cryptosporidium e possuem aproximadamente o mesmo tamanho do protozoário.

Amostras de vários pontos de dois importantes rios de Hong-Kong foram analisadas, durante 13 meses consecutivos, quanto à presença dos protozoários (HO e TAM 1998). Foi encontrado um maior numero de amostras positivas de Giardia em pontos próximos a áreas mais povoadas de ambos os rios, em concentrações variáveis entre 2 e 468 cistos/L no rio Lam Tsuen e não detectada a $>100$ cistos/L no rio Shing Mun. Os oocistos de Cryptosporidium foram detectados apenas uma vez em cada um dos 4 pontos de amostragem do rio Lam Tsuen, em densidades de $3-30$ oocistos/10L e uma vez em 2 dos 3 pontos de amostragem do rio Shing Mun, em concentrações de 13 e 10 oocistos/10L.. Os autores comentam que essa porcentagem de resultados positivos para o Cryptosporidum pode estar relacionada à ausência de fontes de contaminação animal ao longo das margens desses rios, e à baixa incidência de criptosporidiose entre os habitantes da região.

ROUQUET et al. 2000 estudaram as concentrações de Giardia e Cryptosporidum nos dois principais rios da região de Paris. De acordo com esses autores, as concentrações de Cryptosporidium foram menores que as de Giardia, e permaneceram abaixo do limite de detecção (1 oocisto/L) para a maior parte das amostras $(60 \%)$, ultrapassando valores de 5 oocistos/L, em apenas duas ocasiões. Entretanto, as concentrações de Giardia raramente (10\%) estiveram abaixo desse limite ( 1 cisto/L), os valores mais elevados tendo sido superiores a 2.500 cistos/100L no rio Marne, no início do mês de setembro. 


\section{2 - Resultados das Análises de Giardia sp e Cryptosporidium sp em cada}

\section{UGRHI}

\subsection{1 - UGRHI 02 - Paraíba do Sul}

Apesar das porcentagens de amostras positivas para Giardia sp nos pontos de captação localizados no rio Paraiba terem sido bastante próximas $(40 \%$ e $50 \%$, respectivamente para as captações de Tremembé e Jacarei), deve-se observar que as concentrações do protozoário foram bem mais elevadas no $2^{\circ}$ ponto. Assim, em 3 das 4 amostras positivas detectadas junto à captação de Tremembé, as densidades de Giardia sp variaram entre 3 a 4 cistos $/ L$, somente tendo sido verificado um valor mais elevado (42 cistos/L) na amostragem realizada em janeiro de 1999 (Tabela 1). Vários autores (ATHERHOLT et al. 1998, GIBSON et al. 1998, SKERRET e HOLAND 2000) relataram maior ocorrência e concentrações mais altas dos protozoários nas estações mais chuvosas, entretanto, nesse trabalho, somente nessa ocasião foi observada uma concentração nitidamente mais elevada de Giardia sp no mês de janeiro, com relação aos demais meses.

Por outro lado, na captação de Jacarei, que somente começou a ser avaliada em outubro de 1999, as concentrações de Giardia sp variaram entre 20 e 87 cistos/L nas amostragens realizadas em fevereiro, abril e junho de 2000. As análises de coliformes fecais e estreptococos fecais revelaram valores mais elevados na captação de Tremembé (Figura 15), com valores máximos de $160.000 \mathrm{NMP} / 100 \mathrm{~mL}$ de coliformes fecais em junho de 2000, enquanto que para o Clostridium perfringens as diferenças entre esses pontos foram menos acentuadas. Os resultados dos indicadores estão coerentes com dados da CETESB (CETESB 1999 e 2000), segundo os quais as águas do rio Paraiba apresentam boa qualidade no trecho inicial entre Santa Bárbara e Jacareí, piorando a jusante desse último municipio atingindo um nivel crítico na região de Caçapava, conforme demonstram os resultados das análises de condutividade, oxigênio dissolvido e coliformes fecais realizadas em 8 pontos localizados ao longo do rio. $\mathrm{O}$ trecho seguinte, 
até Tremembé, apresenta melhoria na qualidade da água, segundo os resultados de oxigênio dissolvido.

Deve-se assinalar que na captação de Tremembé, foi registrada, no mês de agosto de 1999, a ocorrência de uma dentre as 7 amostras positivas para Cryptosporidium sp detectadas nesse trabalho

Conforme jả apresentado no item Resultados, não foram detectadas amostras positivas para Giardia sp ou Cryptosporidium sp no $3^{\circ}$ ponto de captação dessa UGRHI, localizado no reservatório Jaguari, ponte na rodovia que liga Santa Isabel a Igaratá, no município de Santa Isabel (Tabela 1). Os indicadores bacterianos de contaminação fecal, coliformes fecais e estreptococos fecais estiveram em concentrações bem menores nesse ponto, em relação aos demais locais de amostragem dessa bacia (Figura 15). Já quanto às densidades de C'. perfiringens, não foi observada uma diferença tão acentuada. Entretanto, de acordo com outros parâmetros de qualidade das águas (fósforo e condutividade) avaliados pela CETESB (CETESB 1999 e 2000), esse trecho inicial do reservatório Jaguari apresenta piores condições em comparação à região do municipio de Igaratá.

\subsection{2 - UGRHI 05 - Piracicaba, Capivari, Jundiaí}

Deve-se inicialmente observar que nessa bacia hidrográfica ocorreram tanto altas porcentagens de resultados positivos para Giardia sp, bem como elevadas densidades do protozoário, superiores a 100 cistos/L em várias amostragens. Do ponto de vista da qualidade bacteriológica, vários pontos de captação apresentaram-se comprometidos.

No rio Piracicaba, na captação de Piracicaba, $80 \%$ das amostras foram positivas para Giardia $\mathrm{sp}$, em concentrações maiores que 100 cistos/L nas amostragens realizadas em setembro de 1999, maio e julho de 2000 (Tabela 2), meses nos quais, normalmente, é baixa a precipitação pluviométrica. Por outro lado, nesse mesmo rio, na captação de Americana, as porcentagens de positividade e as concentrações de Giardia sp foram bem 
menores: o protozoário foi isolado em $27 \%$ das amostras, em densidades máximas de 40 cistos/L (Tabela 2).

Apesar desses dois pontos de captação do rio Piracicaba terem apresentado má qualidade bacteriológica, as concentrações dos indicadores de contaminação fecal foram nitidamente maiores no ponto de captação de Piracicaba que naquele situado na captação de Americana (Figura 16). Portanto, nesse caso, avaliação parasitológica e bacteriológica foram coerentes. Esses resultados estão igualmente de acordo com outros dados de qualidade das águas da CETESB 1999, 2000 (matéria orgànica biodegradável, fósforo total e residuo não-filtrável), referentes ao rio Piracicaba, que demonstram uma degradação mais acentuada somente após a contribuição do ribeirão dos Quilombos, após a captação de Americana portanto. Esse ribeirão recebe os esgotos domésticos dos municipios de Campinas, Sumare e Americana. Embora na avaliação realizada pela Companhia Ambiental em 1999, apenas os dados de fósforo total apontassem manutenção da má qualidade no trecho seguinte, entre os municípios de Piracicaba e Americana (onde está localizada a captação de Piracicaba), nos dados de 2000, tanto condutividade como oxigênio dissolvido demonstram esse fato. Nesse trecho, essa má qualidade das águas tem como causa o lançamento de esgotos domésticos das cidades de Limeira e Santa Bárbara do Oeste.

Quanto às amostragens realizadas no rio Atibaia, as porcentagens de amostras positivas para Giardia sp foram próximas ( $55 \%$ na captação n ${ }^{\circ} 3$ de Campinas e $40 \%$ na captação de Atibaia). No que diz respeito às concentrações do protozoário, maiores valores foram detectados na captação de Campinas ( 521 cistos/L) em março de 1999 , enquanto que na captação de Atibaia o nivel máximo observado foi 40 cistos/L, em julho de 1999 (Tabela 3). Similarmente à situação verificada nos pontos de captação do rio Piracicaba, esses dois locais de amostragem do rio Atibaia apresentaram má qualidade bacteriológica, mas as densidades de coliformes fecais foram bem mais elevadas na captação de Campinas, em concordância portanto com os maiores valores de Giardia sp. Deve-se inclusive ressaltar que na amostra coletada em março de 1999 , foi obtido o nível máximo para o protozoário ( 521 cistos/L) e igualmente a concentração mais elevada de coliformes fecais nesse ponto $(800.000 \mathrm{NMP} / 100 \mathrm{~mL})$. Os níveis de 
estreptococos fecais e $C$. perfingens foram apenas ligeiramente mais elevados na captação de Campinas que na captação de Atibaia (Figura 17). Outros dados da CETESB 1999, 2000 (matéria orgânica biodegradável, condutividade, fósforo total e resíduo não-filtrável) no ponto situado na captação de Campinas também indicam má qualidade das águas. A contaminação deve-se ao fato desse ponto estar situado a jusante do pólo industrial de Paulínia e do ribeirão Anhumas, que recebe parte dos esgotos domésticos de Campinas (cerca de 35\%). Esse ponto recebe igualmente as águas do ribeirão Pinheiros, que por sua vez recebe grande parte dos esgotos domésticos de Valinhos e Vinhedo.

No $5^{\circ}$ ponto de captação estudado nessa bacia, no rio Capivari, na captação da ETA 4 da cidade de Campinas, os resultados das análises parasitológicas e bacteriológicas foram concordantes. Assim, esse ponto apresentou 50\% de positividade para Giardia sp e niveis relativamente elevados do protozoário (máximo de 73 cistos/L) detectados na amostragem realizada em setembro de 1999, única ocasião na qual o Cryptosporidium $\mathrm{sp}$ foi detectado nessa UGRHI, na concentração de 3 oocistos/L (Tabela 4). As concentrações de todos os indicadores de contaminação fecal estiveram bastante elevadas em quase todas as coletas (Figura 18). Outros dados de qualidade das águas da CETESB 1999, 2000 (matéria orgânica biodegradável, fósforo total e resíduo nãofiltrável) somente evidenciam uma piora na qualidade das águas após esse ponto.

Embora os protozoários não tenham sido detectados em nenhuma das amostragens realizadas no último ponto de captação estudado nessa bacia (reservatório do ribeirão Pirai, na captação dos municípios de Salto e Indaiatuba), as concentrações dos indicadores de contaminação fecal apresentaram-se elevadas em algumas amostragens realizadas no ano de 1999, e dados da CETESB 1999 e 2000 também indicaram certa degradação das águas demonstrada pelos niveis de fósforo total. 


\subsection{3 - UGRHI 06 - Alto Tietê}

Nessa bacia observou-se sempre concordância entre os resultados das análises parasitológicas e bacteriológicas, tendo sido verificada igualmente uma ampla variação na qualidade dos corpos d'água estudados. Assim, dentre os 11 pontos de captação, 7 apresentaram porcentagem de positividade nula ou de $10 \%$ (1 amostra positiva em 10) para Giardia sp e quase sempre baixas concentrações dos indicadores de contaminação fecal. Por outro lado, em dois desses pontos, a Giardia sp foi detectada em quase todas as amostragens, em densidades relativamente elevadas, e as análises das bactérias indicadoras de contaminação fecal revelaram concentrações extremamente elevadas. $O$ Cryptosporidium $\mathrm{sp}$ foi detectado apenas em uma ocasião num dos corpos d'água que apresentaram boa qualidade.

$\mathrm{Na}$ bacia do rio Tietê Alto, Cabeceiras, dois dos três pontos avaliados apresentaram boa qualidade, uma vez que no reservatório do Taiaçupeba, os protozoários não foram detectados em nenhuma das amostragens e no reservatório Jundiai somente uma amostra foi positiva para Giardia sp na concentração de 3 cistos/L, na amostragem realizada em março de 2000 (Tabela 5). Os coliformes fecais e estreptococos fecais estiveram presentes em concentrações relativamente baixas, devendo-se observar que as densidades do $C$. perfringens foram nitidamente mais elevadas, principalmente no reservatório Taiaçupeba (Figura 19). Segundo a CETESB 1999 e 2000, os niveis médios de fósforo total acima do padrão de qualidade, têm contribuido para o processo de eutrofização que vem ocorrendo nesses locais

O $3^{\circ}$ ponto de captação do Tietê Alto Cabeceiras apresentou comprometimento da qualidade de suas águas tanto do ponto de vista parasitológico como bacteriológico. Embora a porcentagem de amostras positivas para Giardia sp não tenha sido muito elevada (27\%), o protozoário foi detectado em altas concentrações nos meses de janeiro, março e setembro de 1999 (50-93 cistos/L - Tabela 5). As concentrações dos indicadores de contaminação fecal foram bastante elevadas nesse ponto (Figura 19).

Os dois pontos de captação estudados no reservatório Billings (braço do Taquacetuba e reservatório do Rio Grande) apresentaram boa qualidade nesse trabalho, uma vez que 
nenhum dos protozoários foi detectado em todo o período de estudo (Tabela 6) e as concentrações dos indicadores de contaminação fecal permaneceram bastante baixas nesses locais (Figura 20), a não ser pelos valores relativamente elevados do $C$. perfringens no braço do Taquacetuba. Dados da CETESB 1999 (fósforo total, oxigênio dissolvido e DBO) e CETESB 2000 (fósforo total) demonstraram uma melhoria da qualidade das águas nesses pontos.

Pode-se igualmente considerar boa a qualidade das águas do ponto de captação avaliado no reservatório Guarapiranga, embora a Giardia sp e o Cryptosporidium $\mathrm{sp}$ tenham sido detectados, nas concentrações de 13 cistos $/ \mathrm{L}$ e 3 oocistos/L, respectivamente, na amostragem realizada em setembro de 1999 (Tabela 6). As densidades das bactérias indicadoras de contaminação fecal foram baixas (Figura 20), a não ser pelo valor detectado em janeiro de 2000 para coliformes fecais $(5.000$ $\mathrm{NMP} / 100 \mathrm{~mL}$ ) e pelas densidades relativamente elevadas de (C. perfringens nesse local. De acordo com a CETESB 1999 e 2000, esse ponto de captação da represa Guarapiranga tem apresentando melhor qualidade sanitária e uma tendência de redução nos níveis de fósforo nos últimos anos

Nos dois pontos avaliados na bacia do rio Cotia, a qualidade das águas apresentou-se bastante diferente, tendo sido igualmente observada uma boa concordância entre avaliação parasitológica e bacteriológica. No reservatório das Graças, Cotia Alto, nenhum dos protozoários foi detectado nas 9 amostragens realizadas e as concentrações dos indicadores de contaminação fecal foram bastante baixas (Tabela 7, Figura 21). Em contraste, no rio Cotia, ETA do Cotia Baixo, todas as amostras foram positivas para Giardia sp em concentrações variáveis entre $35-215$ cistos $/ \mathrm{L}$, e as densidades dos indicadores de contaminação fecal foram bastante altas (Tabela 7, Figura 11). Essa diferença acentuada na qualidade das águas nesses dois pontos também foi demonstrada através da análise de outros parâmetros (fósforo total, resíduo não-filtrável $e$ condutividade), e deve-se ao fato desse $2^{\circ}$ ponto estar ainda estar sob a influência do lançamento de efluentes domésticos e industriais da cidade de Cotia, que ocorre num ponto do rio situado a jusante do município (CETESB 1999 e 2000). 
Nos très pontos localizados na zona metropolitana da bacia do Tietê Alto, observouse grande variação na qualidade das águas, tanto do ponto de vista parasitológico como bacteriológico. Entretanto, os resultados dessas análises não foram exatamente coerentes, uma vez que no reservatorio Tanque Grande, apesar da ausência de Giardia sp e Cryptosporidium sp em todas as amostras (Tabela 8) foram registrados valores elevados de coliformes fecais em algumas coletas $(30.000 \mathrm{NMP} / 100 \mathrm{~mL}$ - maio de 1999). Por outro lado, no reservatório do rio Juqueri, no qual $30 \%$ das amostras foram positivas para Giardia sp (Tabela 9), as concentrações das bactérias indicadoras de contaminação fecal foram bem mais baixas, com exceção dos niveis de C. perfringens, cujas médias geométricas foram similares nesses dois pontos (Figura 22). Segundo avaliações realizadas pela CETESB 1999 e 2000, o reservatório Tanque Grande apresenta poucas não-conformidades nos parâmetros sanitários (oxigênio dissolvido, demanda bioquimica de oxigênio, fósforo total e resíduo não-filtrável), e, portanto, é ainda adequada sua preservação. Quanto ao reservatório Juqueri, dados da CETESB (CETESB 1999) quanto ao oxigênio dissolvido, demanda bioquimica de oxigênio, fósforo total e residuo não-filtrável e CETESB 2000 (evolução temporal das densidades de coliformes fecais nos últimos 10 anos) demonstram uma boa condição nesse manancial. No ribeirão dos Cristais, a elevada porcentagem de amostras positivas para Giardia sp (78\%) em concentrações relativamente altas (Tabela 8 ) está de acordo com as análises bacteriológicas, uma vez que as três bactérias indicadoras de contaminação fecal apresentaram densidades elevadas (Figura 22). Além disso, resultados das análises de fósforo total nesse local também são coerentes com esses dados (CETESB $1999 \mathrm{e}$ 2000) 


\subsection{4 - UGRHI 07 - Baixada Santista}

Os dois pontos de captação estudados nessa bacia apresentaram a mesma porcentagem de amostras positivas para Giardia sp $(20 \%)$, em concentrações relativamente baixas (Tabela 9). Entretanto, a qualidade bacteriológica do rio Cubatão foi bastante inferior àquela do reservatório Capivari-Monos, considerando-se os valores mais elevados observados para coliformes fecais e estreptococos fecais, enquanto que as densidades de C. perfingens foram bastante semelhantes nos dois locais (Figura 23). Ainda no reservatorio Capivari-Monos, foi detectada, em maio de 1999, a concentração mais elevada de Cryprosporidium sp observada nesse estudo (20 oocistos/L). Nessa mesma amostra a Giardia sp estava presente na concentração de 3 cistos/L, e os indicadores de contaminação fecal apresentaram-se em densidades muito baixas $(4 ; 4$ e 9 NMP/100mL, respectivamente, para os coliformes fecais, estreptococos fecais e $C$. perfringens). Deve-se assinalar que embora o reservatório Capivari-Monos tenha apresentado boa qualidade bacteriológica, com as médias geométricas das bactérias indicadoras de contaminação fecal variando entre 6,9 a $80,9 \mathrm{NMP} / 100 \mathrm{~mL}$, esses indicadores atingiram valores elevados na amostra coletada em janeiro de 2000 (coliformes fecais, estreptococos fecais e C. perfingens: 22.000, 5.000 e 800 NMP/100mL. respectivamente), mas nenhum dos protozoários foi detectado nessa ocasião. Dados da CETESB 1999 e 2000 não indicam más condições de outros parâmetros no ponto situado no rio Cubatão, que está situado a montante do canal de fuga da usina Hidroelétrica Henry Borden, não sendo assim influenciado pelas águas do reservatório Billings. Quanto ao reservatório Capivari-Monos, em 1999, foram observadas não-conformidades para os parâmetros sanitários fósforo total e DBO somente uma vez, o que demonstra boa qualidade portanto. No ano de 2000 , entretanto valores acima do padrão para fósforo total foram registrados três vezes nesse local (inclusive em janeiro de 2000). 


\subsection{5 - UGRHI 09 - Mogi-Guaçú}

No ponto de captação estudado nessa bacia, na ETA da Academia da Força Aérea de Pirassununga, 50\% das amostras foram positivas para Giardia sp, em concentrações relativamente baixas. O Cryptosporidium sp foi detectado em abril de 1999, na densidade de 2 oocistos/L, e nessa mesma amostra a Giardia sp apresentou-se na concentração mais elevada observada nesse local (31 cistos/L) (Tabela 10). Embora as médias geométricas dos três indicadores de contaminação fecal tenham sido inferiores à $1000 \mathrm{NMP} / 100 \mathrm{~mL}$ (Figura 24), foram registrados valores máximos relativamente elevados em algumas coletas (janeiro e dezembro de 1999: coliformes fecais 1.700 NMP/100mL: abril de 1999: estreptococos fecais 5.000 NMP/100mL: outubro de 1999: C. perfringens $1.700 \mathrm{NMP} / 100 \mathrm{~mL}$ ). Segundo avaliações realizadas CETESB $1999 \mathrm{e}$ 2000, os parâmetros condutividade e coliformes fecais indicam pior qualidade da água no trecho inicial do rio Mogi-Guaçú, onde estão localizados os municípios mais populosos da região (Mogi-Guaçú e Mogi-Mirim), observando-se uma recuperação no ponto estudado nesse trabalho.

\subsection{6 - UGRHI 10 - Sorocaba, Médio Tietê}

No ponto estudado nessa bacia (reservatório Itupararanga), foi boa a qualidade bacteriológica e parasitológica da água, uma vez que nenhum dos protozoários foi detectado nas 11 amostragens realizadas (Tabela 11) e as médias geométricas das bactérias indicadoras de contaminação fecal estiveram abaixo de $10 \mathrm{NMP} / 100 \mathrm{~mL}$ (Figura 25). Segundo a Companhia Ambiental (CETESB 1999 e 2000), outros dados (residuo não-filtrável, fósforo total, demanda bioquímica de oxigênio, oxigênio dissolvido e condutividade) indicaram igualmente boa preservação das águas. 


\subsection{7 - UGRHI 15 - Turvo Grande}

No ponto avaliado nessa bacia (reservatório do Rio Preto), verificou-se desacordo entre a avaliação bacteriológica e parasitológica. Assim, apesar das altas concentrações dos indicadores de contaminação fecal (Figura 26), a Giardia sp apenas foi detectada em uma das 9 amostras coletadas no local, na densidade de 1 cisto/L. Dados de fósforo total em algumas amostragens desse ponto também indicam certa degradação da qualidade das águas, embora os resultados de oxigênio dissolvido e nitrogênio amoniacal sejam satisfatórios (CETESB 1999 e 2000).

\subsection{8 - UGRHI 17 - Médio Paranapanema}

A Giardia sp foi detectada em $50 \%$ das amostras analisadas no rio Pardo, em concentrações máximas de 40 cistos/L, detectadas em abril de 1999 (Tabela 12), coincidentemente com a mais alta densidade de coliformes fecais verificada nesse local (130.000 NMP/100mL). Não houve sempre entretanto concordância entre as análises bacteriológicas e parasitológicas, pois as concentrações dos indicadores de contaminação fecal permanceram elevadas durante todo o periodo de estudo, observando-se valores de $10^{3}-10^{4} \mathrm{NMP} / 100 \mathrm{~mL}$ em várias amostragens, concomitantemente com ausência do protozoário. $\mathrm{Na}$ amostra coletada em junho de 1999, foram detectados tanto a Giardia sp como o Cryptosporidium sp, nas densidades de 13 cistos/L e 7 oocistos/L. Segundo a CETESB 1999 e 2000, também os resultados das análises de fósforo total e condutividade demonstram más condições, atribuídas ao lançamento de esgotos domésticos provenientes do município de Ourinhos. 


\subsection{9 - UGRHI 21 - Peixe}

No rio do Peixe. a Giardia sp foi detectada em 50\% das amostras, em concentrações máximas de 35 cistos/L, resultado obtido na amostragem realizada em junho de 1999, quando também foi isolado o (ryptosporidium $\mathrm{sp}$, na concentração de 2 oocistos/L. Essa porcentagem de amostras positivas para o protozoário não apresenta uma boa concordância com as análises bacteriológicas, cujos resultados foram elevados em todas as amostras, situação bastante semelhante àquela observada no rio Pardo. Segundo a CETESB 1999 e 2000, esse trecho do rio do Peixe recebe esgotos domésticos brutos da cidade de Marilia, e dados de fósforo total e condutividade são concordantes com a avaliação parasitológica e bacteriológica.

\subsubsection{0 - UGRHI 10 - Pontal do Paranapanema}

Foi boa a qualidade parasitológica no ponto avaliado nessa bacia, localizado no rio Paraná, pois nenhum dos protozoários foi detectado nas 9 amostragens realizadas nesse local (Tabela 15). As médias geométricas das concentrações dos indicadores de contaminação fecal foram baixas (Figura 29), mas em algumas coletas foram observados valores relativamente elevados de coliformes fecais $(2.300$ e $3.000 \mathrm{NMP} / 100 \mathrm{~mL}$ em junho e dezembro de 1999). Avaliações realizadas pela CETESB 1999 e 2000 indicam boa qualidade das águas do rio Paraná nesse ponto. 


\section{3 - Relação entre as Concentrações dos Protozoários e dos Indicadores de Contaminação Fecal}

\subsection{1 - Utilização do Coeficiente de Postos de Spearman para Estudo da Correlação entre Parâmetros Microbiológicos de Qualidade da Água}

A medida estatística clássica de correlação entre dois conjuntos de dados é o coeficiente produto-monento, $\mathbf{r}$, bastante conhecido como coeficiente de correlação de Pearson, comumente citado e facilmente disponivel em vários programas estatísticos para computador. Trata-se, entretanto de um teste paramétrico, que exige que os dados ou seu logaritmo assumam uma distribuição normal. Raramente os resultados de análises microbiológicas apresentam esse tipo de distribuição. Com freqüência esses valores abrangem algumas ordens de magnitude e ocorrem vários resultados abaixo do limite de deteç̧ão, assumindo-se para eles o valor nulo. Segundo TILLET et al. 2001, nesses casos deve ser utilizado, para estudo da relação quantitativa entre tais resultados um teste estatístico não-paramétrico, como por exemplo o coeficiente de correlação de Spearman, que comparara a posição de postos ("ranking") dos resultados dos dois parâmetros em estudo. Trata-se exatamente do tipo de dados obtidos nesse trabalho, uma vez que as concentrações dos indicadores de contaminação fecal apresentaram na maioria dos pontos de captação uma variação bastante ampla, da ordem de $10^{0}$ até $10^{5}$ NMP/100mL, e foi observada ausência para a maior parte dos resultados das análises dos protozoários. Nesse ensaio não-paramétrico, a correlação não é estabelecida diretamente entre os resultados obtidos. Ao invés, os resultados de cada parâmetro recebem um posto ou ordem $\left(1^{\circ}, 2^{\circ}, 3^{\circ}\right.$, etc. $)$, em ordem crescente, de acordo com seu valor, e os postos dos dois conjuntos de parâmetros são então comparados. Obtém-se um valor $\mathbf{R}$ (coeficiente de correlação de Spearman) e para avaliar-se a significância do valor obtido, calcula-se um valor $\mathbf{t}$ para o qual existem tabelas especificas

Com respeito a esse tipo de avaliação, para TILLET et al. 2001, a questão mais adequada, no caso de paràmetros microbiológicos, não é se o parâmetro A correlacionase ao parâmetro B. Para esses autores, na avaliação microbiológica da água, quando se 
objetiva encontrar indicadores de contaminação fecal, e assim, a possível presença de microrganismos patogênicos, deve-se ainda pesquisar se os parâmetros em questão tem origem exclusiva de contaminação fecal humana e se eles sobrevivem por longos periodos de tempo, refletindo dessa forma tanto eventos passados como recentes. Eles sugerem assim planejamentos especiais para esses estudos.

\subsection{2 - Resultados da Correlação de Postos de Spearman entre as Concentrações de Cryptosporidium sp e dos Indicadores de Contaminação Fecal}

Conforme já citado no item Resultados não foi possivel a aplicação do teste estatístico para avaliar-se a relação entre as concentrações de Cryptosporidium sp e dos indicadores de contaminação fecal, em virtude do pequeno número de resultados positivos para esse protozoário ( 7 em 278 ).

\subsection{3 -Resultados da Correlação de Postos de Spearman entre as Concentrações de Giardia sp e dos Indicadores de Contaminação Fecal}

Considerando-se a totalidade dos resultados $(n=278)$, foi obtida uma correlação altamente significativa entre as concentrações de Giardia sp e as concentrações dos três indicadores de contaminação fecal analisados (Tabela 16). Em ordem de magnitude, a correlação foi maior para os coliformes fecais, seguindo-se os estreptococos fecais e por último o Clostridium perfringens. Esse resultado, em aparente contradição com o fato dessas bactérias não serem indicadores adequados da presença dos protozoários e com resultados da literatura, pode ser explicado pelas características de qualidade de água dos pontos de captação avaliados. Assim, esses 28 corpos d'água, apresentavam, em sua maioria, variações extremas na qualidade, e em muitos pontos as concentrações dos 
indicadores eram bastante baixas e neles verificou-se pequena porcentagem de amostras positivas para Giardia sp, ou ausência do protozoário em todas as amostragens, enquanto que em alguns pontos, associada a densidades extremamente elevadas dessas bactérias, observou-se grande número de amostras positivas para Giardia sp, em densidades altas igualmente. Dentre os 14 pontos cujas porcentagens de positividade para o protozoário situavam-se entre 0 e 20\% (Figura 13), 11 apresentaram médias geométricas das concentrações de coliformes fecais e estreptococos fecais inferiores a 200NMP/100mL, e em 12 esses valores eram inferiores a $200 \mathrm{NMP} / 100 \mathrm{~mL}$ para o $C$. perfringens. Por outro lado, nos 9 pontos nos quais foram verificadas porcentagens de amostras positivas para Giardia sp superiores a $41 \%, 7$ revelaram médias geométricas das concentrações de coliformes fecais e estreptococos fecais em ordem de magnitude igual ou superior a $10^{3} \mathrm{NMP} / 100 \mathrm{~mL}$, e em 6 esses valores eram da ordem de $10^{3} \mathrm{NMP} / 100 \mathrm{~mL}$ para o C. perfringens. Essa concordância na qualidade bacteriológica e parasitológica em vários pontos de captação, já tinha sido assinalada na discussão dos resultados das análises dos indicadores e dos protozoários em cada UGRHI, e pode ter contribuido para obtenção de valores de correlação de Spearman significativos. Deve-se igualmente levar em consideração a baixa recuperação da metodologia empregada, que, embora não tenha sido determinada nas condições desse trabalho, conforme já citado, situa-se entre 30 e $40 \%$ (FRICKER e CRABB 1998), sendo assim possivel que a detecção de amostras positivas para os protozoários somente tenha ocorrido naqueles corpos d'água altamente contaminados. Ao contrário do que vem sendo relatado com freqüência na literatura, não foram observadas nesse trabalho amostras positivas para Giardia sp e Cryptosporidium $\mathrm{sp}$ nos corpos d'água que apresentavam boa qualidade (Lisle e Rose 1995, citado por ROSE 1997). De qualquer maneira, esses resultados da análise estatística demonstram que, nas condições experimentais desse trabalho, elevadas concentrações dos indicadores de contaminação fecal indicam a possivel presença da Giardia sp, em concentrações igualmente elevadas. Essa afirmação não pode ser feita entretanto para todas as UGRHIs, pois conforme ainda será discutido, a avaliação estatística não revelou o mesmo tipo de associação entre Giardia sp e indicadores em todas as bacias. 
Nas Unidades de Gerenciamento de Recursos Hidricos 5 e 6 foi bastante significativa a correlação entre as concentrações de Giardia sp e os três indicadores de contaminação fecal (Tabelas 18 e 19). Esse resultado deve-se não apenas ao grande número de amostras analisado nessas bacias, como também à concordância sempre observada entre os resultados das análises bacteriológicas e parasitológicas. Assim, dentre os 18 pontos de captação estudados nessas UGRHIs, em 9 nos quais as porcentagens de amostras positivas para Giardia sp eram de 0 a $20 \%$, as médias geométricas das concentrações das bactérias indicadoras de contaminação fecal eram da ordem de grandeza de $10-10^{2}$ NMP/100mL. Por outro lado, em 7 dos 9 corpos d'água remanescentes, onde as porcentagens de positividade para o protozoário variaram entre 40 e $100 \%$, as médias geometricas das concentrações dos três indicadores de contaminação fecal apresentaram magnitudes de $10^{3}$ a $10^{+} \mathrm{NMP} / 100 \mathrm{~mL}$.

Na UGRHI 2, Paraiba do Sul foi verificada uma correlação bastante significativa entre Giardia sp e coliformes fecais (Tabela 17). Essa correlação pode ser explicada pela concordância entre os resultados das análises bacteriológicas e parasitológicas observada nesses locais, uma vez que as concentrações desses dois indicadores de contaminação fecal foram muito menores no ponto de captação localizado no reservatório do Jaguari, no qual a Giardia sp não foi detectada, e bem mais elevadas nos dois locais avaliados no rio Paraiba (Figura 15). Não foi observada correlação significativa entre as densidades de Giardia sp e C. perfringens, e, de fato, as médias geométricas das densidades desse indicador de contaminação fecal remota, representadas na Figura 15, foram bastante semelhantes nesses 3 pontos, apesar das diferenças nos resultados das análises parasitológicas.

Para as UGRHIs $7,9,10,15,17$ e 22 não foram obtidas correlações significativas entre as concentrações de Giardia sp e os indicadores de contaminação fecal. Além do pequeno número de observações ( $\mathbf{n}$ entre 9 e 11) para cada uma dessas bacias, outros fatores próprios a cada conjunto de resultados contribuíram igualmente para esses resultados. Na UGRHI 7 por exemplo, houve evidente incoerência entre os resultados das análises bacteriológicas e parasitológicas, enquanto que nas UGRHIs 10 e 22 a 
Giardia sp não foi detectada em nenhuma das amostragens realizadas. e na UGRHI 15 somente uma em onze amostras apresentou resultado positivo para o protozoário

Quanto à UGRHI 21, não foram obtidas correlações significativas entre as concentrações de Giardia sp e de coliformes fecais e estreptococos fecais. Foi verificada entretanto, uma correlação negativa bastante significativa (Tabela 24) entre os resultados das análises do protozoário e do $C$. perfringens. De acordo com essa correlação, nesse local, elevadas concentrações do indicador seriam indício de baixas concentrações ou de ausência do protozoário, o que está em desacordo com as caracteristicas de resistência e persistência no ambiente dessa bactéria, mais semelhantes aos dos protozoários que dos demais indicadores.

Vários outros autores estudaram as relações entre as concentrações dos protozoários Giardia sp e cryptosporidium $\mathrm{sp}$ e as de outros indicadores microbiológicos e fisicoquímicos de qualidade da água, determinando a correlação entre os mesmos. ROSE et al. 1988 determinaram os coeficientes de correlação de Pearson entre os resultados das análises desses protozoários, coliformes totais, coliformes fecais e turbidez de 39 amostras de um rio, situado na região oeste dos Estados Unidos, cujas águas seriam futuramente utilizadas para captação. Não foi observada uma associação entre as bactérias do grupo coliforme, turbidez e oocistos de Cryptosporidium ou cistos de Giardia. Segundo os autores, esse fato demonstra que essas variáveis são inadequadas para demonstrar a ausência, presença ou nível dos protozoários no sistema aquático avaliado.

Numa avaliação realizada durante três meses em 51 amostras de águas de rios da região de Ottawa, no Canadá, CHAURET et al. 1995 utilizaram o coeficiente de correlação de Spearman para analisar a força da associação entre as concentrações de coliformes totais, fecais, estreptococos fecais, Clostridium perfringens, Aeromonas $\mathrm{sp}$, colifagos somáticos e algas (clorofila a). De acordo com seus resultados foi obtida uma correlação significativa entre estreptococos fecais e oocistos de Cryptosporidium, e entre colifagos somáticos e algas e os cistos de Giardia. Similarmente ao ocorrido nesse trabalho, esses autores observaram que o coeficiente de correlação de Spearman apresentou grande variação, em alguns casos, quando os dados eram agrupados por 
corpo d'água, ao invés de serem analisados na totalidade. Num desses casos, a presença de estreptococos fecais era significativamente correlacionada com a presença de oocistos de Cryptosporidium somente para o conjunto de dados. Quando a associação era analisada para cada rio separadamente, a correlação não era significativa.

ATHERHOLT et al. 1998 utilizaram igualmente esse ensaio para estudar a relação entre as concentrações de Giardia. Cryptosporidium e vários parâmetros microbiologicos (coliformes totais, coliformes fecais, Escherichia coli. Clostridium perfiringens e colifagos) e meteorológicos, em 72 amostras coletadas no rio Delaware, em Trenton, New Jersey, nos Estados Unidos. Previamente os autores estudaram a distribuição dos dados para verificar se poderia ser aplicado o coeficiente do correlação de Pearson diretamente ou após transformação dos dados, concluindo que o teste não paramétrico era o mais adequado.Foi observada uma correlação significativa entre as concentrações de Giardia e coliformes totais, Escherichia coli $(\mathrm{p}<0,05)$, Clostridium perfringens e colifagos somáticos $(\mathrm{p}<0,01)$. Para o Cryptosporidium $\mathrm{sp}$ foi observada uma correlação significativa $(p<0,01)$ com coliformes totais, coliformes fecais, Escherichia coli, Clostridium perfringens e colifagos.

Utilizando o coeficiente de correlação de Pearson, DIAS JÚNIOR 1999 obteve resultados significativos $(p<0,05)$ entre as concentrações de Giardia e estreptococos fecais para 12 amostras de águas superficiais provenientes do município de Araras, no estado de São Paulo. Por outro lado, MULLER 1999, utilizando o mesmo teste estatístico, não obteve correlações significativas entre as concentrações de Cryptosporidium e coliformes totais e Escherichia coli em 12 amostras de água bruta coletadas na cidade de São Paulo.

Nesse trabalho, foram estudados como indicadores bacterianos alternativos à avaliação da qualidade microbiológica_da água, os estreptococos fecais e o $C$. perfringens. Os coliformes fecais, que também foram avaliados, fazem parte dos parâmetros tradicionalmente estudados no Programa de Avaliação da Qualidade das Águas Interiores do Estado de São Paulo da Companhia de Tecnologia e Saneamento Ambiental - CETESB. Conforme já apresentado no item Objetivos, pretendeu-se 
determinar a eventual existência de uma relação quantitativa entre as concentrações dos protozoários e os indicadores citados.

\subsection{4 - Os Indicadores Bacterianos de Contaminação Fecal na Avaliação da Qualidade Microbiológica da Água}

Desde a década de 70 vem sendo discutida e contestada a relevância da utilização dos indicadores bacterianos de contaminação fecal, em particular dos coliformes, como critério exclusivo para garantia da qualidade microbiológica da água. Embora desde o início fosse reconhecida a desvantagem dos coliformes como indicadores da presença de microrganismos patogênicos mais persistentes no ambiente, e mais resistentes aos processos de tratamento da água, como por exemplo os protozoários, fatos e estudos recentes vem demonstrando essa deficiência propondo outras alternativas para atingir-se esse objetivo. Dentre esses, incluem-se relatos da ocorrência de surtos de doenças de veiculação hídrica associados ao consumo de água bacteriologicamente potável e mudanças nas metodologias de análise dos coliformes, que tiveram por conseqüência alterações nos conceitos e abrangência desses indicadores tradicionalmente utilizados na avaliação da qualidade microbiológica da água.

Quanto à ocorrência de doenças de veiculação hídrica, vários levantamentos realizados nos Estados Unidos e Reino Unido associam surtos de gastroenterites associados ao consumo de água que atendia aos critérios vigentes de qualidade bacteriológica (SOLO-GABRIELE et al. 1996; FROST et al. 1996, GOLDSTEIN et al. 1996). Ainda nos Estados Unidos, KRAMER et al. 1996, analisaram a ocorrência de surtos dessas doenças, entre 1984 e 1992, concluindo que todos os surtos de criptosporidiose nesse periodo ocorreram associados ao consumo ou contato com águas isentas de indicadores bacterianos. No Canadá, PAYMENT et al. 1991, estudaram a incidência de gastroenterites em 606 domicílios supridos por água de rede, na região de Montreal. Em 299 desses domicilios foi instalado um sistema de filtração por osmose reversa, enquanto que nos 307 domicílios restantes a água era consumida diretamente do sistema de distribuição, sem qualquer tratamento. Segundo os resultados obtidos, $35 \%$ 
das gastroenterites observadas, num periodo de 15 meses, foram atribuídas ao consumo de água da rede. A água, que atendia a padrões físico-quimicos e microbiológicos vigentes nos Estados Unidos, era proveniente de uma ETA que aplicava tratamento convencional completo a águas captadas de um rio no qual eram lançados efluentes domésticos. CRAUN et al. 1997 avaliaram os dados sobre a presença de coliformes em episódios de surtos de veiculação hídrica que ocorreram nos Estados Unidos entre 1983 e 1992. De acordo com os resultados dessa pesquisa, os coliformes seriam os indicadores adequados da presença potencial de bactérias e vírus em águas de consumo humano, mas não para protozoários de veiculação hídrica. Não seriam igualmente bons indicadores da presença de alguns tipos de vírus ou agregados de virus mais resistentes aos processos de desinfecção. Para os autores é necessário ainda aperfeiçoar-se a investigação epidemiológica dos surtos. Por exemplo, não foi possivel identificar-se o agente etiológico de cerca de $50 \%$ dos surtos de doenças de veiculação hídrica nos Estados Unidos, sendo fundamental o desenvolvimento de métodos diagnósticos para deteç̧ão de microrganismos patogênicos emergentes.

Numa revisão sobre histórico, limitações e atuais tendências para utilização dos coliformes e Escherichia coli para avaliação microbiológica da água, publicada pelo Conselho Nacional de Pesquisa Médica e Sanitária de Austrália (NHMRC 2001), são também discutidas as mudanças desse grupo, conseqüentes à alteração na metodologia de sua determinação. São igualmente citadas alternativas à sua utilização, incluindo microrganismos como os enterococos, clostrídios sulfito-redutores ( $C$. perfringens) Bacterioides fragilis, Bidifobactérias e indicadores não microbianos tais como os esteróis fecais. Outra estratégia discutida nesse documento é a adoção de planos que enfoquem de maneira integrada a avaliação da qualidade da água de consumo humano. Nesses planos os riscos de contaminação do sistema de fornecimento de água são avaliados como um todo, desde a captação até a torneira do consumidor, identificandose as formas através das quais esses riscos podem ser tratados e métodos que assegurem que barreiras e medidas de controle sejam implementadas adequadamente

LECLERC et al 2001, num trabalho de revisão sobre a bacteriologia dos coliformes e sua utilidade como indicadores da qualidade da água, discutem como as novas técnicas 
analíticas utilizadas a partir da década de 60 transformaram a classificação previamente usada para esse grupo. Atualmente, a definição de coliformes, como as bactérias que possuem a enzina $\beta$ - galactosidase, ampliou consideravelmente o grupo, anteriormente bem mais restrito. Assim, esse grupo inclui atualmente microrganismos cujo habitat exclusivo é o trato intestinal de humanos e de animais de sangue quente (apenas a Escherichia coli), coliformes termotróficos que possuem igualmente esse habitat, mas que são mais abundantes no ambiente e finalmente coliformes psicotróficos, cujo habitat é exclusivamente ambiental.

GOFTI et al 1999, numa revisão sobre as limitações dos indicadores bacterianos de contaminação fecal, discute a utilização da avaliação de risco microbiológico para determinar-se a qualidade da água de consumo humano. Esses autores detalham as informações necessárias para avaliação do risco microbiológico, que incluem uma vigilância epidemiológica efíciente, a determinação da relação dose-resposta, a avaliação do grau de exposição e a caracterização quantitativa do risco de infecção.

Por outro lado, GIBSON et al. 1998b, avaliaram o estado de arte da avaliação de risco para protozoários de veiculação hídrica. Esses autores apresentam um histórico do procedimento, utilizado tradicionalmente para contaminantes químicos, e destacam as particularidades da avaliação de risco microbiológico. Concluem que, atualmente, os problemas nas metodologias de detecção dos protozoários, incluindo-se as baixas taxas de recuperação limitam a utilização desse procedimento.

No que diz respeito à utilização de indicadores alternativos MEDEMA et al. 1997 estudaram a sobrevivência de Cryptosporidium parvum, E. coli, enterococos e Clostridium perfringens em águas de rio, avaliando a influência da temperatura e da presença de microrganismos autóctones. Segundo os resultados obtidos, o C. perfringens persistiu por períodos de tempo mais longos que o C. parvim na água de rio, enquanto que a $E$. coli e os enterococos apresentaram um decaimento mais rápido.

PAYMENT e FRANCO 1993 avaliaram o C. perfringens e colifagos somáticos como indicadores da eficiência de tratamento da água para remoção de vírus e protozoários, concluindo que o $C$. perfringens foi o melhor indicador desses processos. 


\section{4-As Metodologias de Análise de Giardia sp e Cryptosporidium sp}

\subsection{1 - O Desenvolvimento das Metodologias de Análise de Giardia sp e Cryptosporidium sp}

Segundo SMITH 1998, o desenvolvimento da metodologia para análise de protozoários em amostras ambientais vem sendo impulsionado nos últimos 30 anos pelos surtos de veiculação hídrica de giardíase, e, mais recentemente de criptosporidiose, destacando-se o surto ocorrido em Milwaukee em 1993. Adicionalmente, a legislação vem estimulando o desenvolvimento dessa metodologia, e, de fato, um dos métodos mais utilizados e estudados atualmente foi proposto pela Agência Ambiental Americana, ou seja o Método 1623 ("Method 1623: Cryptosporidium and Giardia in Water by Filtration/MS/FA" USEPA 1999). Apesar de técnicas de biologia molecular, tais como a Reação em Cadeia da Polimerase (PCR - polymerase chain reaction) (MAHBUBANI et al. 1991; STINEAR et al. 1996) e a detecção através de cultura de células (SLIFKO et al. 1997) terem sido propostas, o ensaio através de microscopia de imunofluorescência continua sendo o mais estudado e utilizado para a análise desses parasitas, e foi aquele empregado nesse trabalho. Algumas dessas metodologias utilizadas para detecção dos parasitas apresentam vantagens importantes em comparação à imunofluorescência, como por exemplo a sensibilidade das técnicas de Biologia Molecular, que permitem ainda a determinação da espécie do protozoário e a verificação da viabilidade dos mesmos através da cultura de células. A detecção através de citometria de fluxo, igualmente proposta, é utilizada em associação à microscopia de imunofluorescência, tornando-a mais efetiva, e reduzindo substancialmente o tempo necessário para exame microscópico das lâminas (MEDEMA et al. 1998). Muito recentemente foi proposto um imunoensaio, para determinação quantitativa, através de eletroquimioluminescência, dos oocistos viáveis de C. parvum presentes em amostras ambientais (CALL et al. 2001, LEE et al. 2001). Possivelmente, a complexidade de algumas dessas técnicas (para o imunoensaio, por exemplo é preciso previamente realizar-se o desencistamento do parasita) e a 
necessidade de equipamentos caros, como no caso da citometria de fluxo, limitam sua utilização pela maior parte dos laboratórios.

Os métodos inicialmente desenvolvidos para a detecção de Giardia foram adaptados para o Cryptosporidium e. hoje, os dois protozoários podem ser analisados na mesma amostra simultaneamente. O ensaio de imunofluorescência para detecção de Giardia foi desenvolvido em 1985 e, segundo SAUCH 1985, citado por LECHEVALIER et al. 1990, apresentou inúmeras vantagens com relação ao método anteriormente utilizado, que empregava flotação com sulfato de zinco e coloração com lugol. Esses últimos autores compararam as duas técnicas para detecção de ambos protozoários em amostras ambientais artificialmente contaminadas com esses organismos, concluindo que o ensaio de imunofluorescência foi cerca de 12 vezes mais sensivel para a detecção de Giardia e que o ('ryptosporidium foi detectado em várias amostras. $\mathrm{O}$ método completo para deteç̧ão dos cistos de Giardia com sulfato de zinco e lugol foi publicada na $16^{\text {a }}$ edição do "Standard Methods for the Examination of Water and Wastewater", e o método utilizando o ensaio de imunofluorescência para determinação de ambos protozoários apareceu inicialmente na $19^{\mathrm{a}}$ edição desse manual (AMıRICAN PUBLIC HEALTH ASSOCIATION 1986 e 1995). A Agência Ambiental Americana, USEPA, por ocasião do estabelecimento da sua legislação de monitoramento, a ICR (Information Collection Rule) em 1996 (USEPA 1996), determinou igualmente o método que deveria ser utilizado para as análises dos microrganismos. Esse método, denominado "ICR Protozoan method for detecting Giardia cysts and Cryptosporidium oocysts in water by a fluorescent antibody procedure" (USEPA 1995), também utilizava o ensaio de imunofluroescência e, de acordo com vários autores apresentava muitas desvantagens, dentre as quais complexidade técnica, baixas e variáveis taxas de recuperação, mesmo quando utilizado por laboratórios experientes, elevado número de resultados falsonegativos e falso-positivos, além de variabilidade e imprecisão devido à análise parcial da amostra (PONTIOUS e CLANCY 1999, CLANCY et al. 1999, ATHERHOLT e KORN 1999, YOUNG e KOMISAR 1999, ALLEN et al. 2000).

Em virtude das deficiências apresentadas pelo método ICR, a agência ambiental americana, desenvolveu um novo método, inicialmente apenas para determinação de 
oocistos de Cryptosporidium, o "Method 1622: Cryptosporidium in Water by Filtration/IMS/FA" (USEPA 1998b), que apresentou uma melhora substancial com relação ao método ICR, uma vez que as taxas de recuperação foram mais elevadas e reprodutiveis e toda a amostra podia ser analisada pela preparação e exame microscópico de uma lâmina apenas. Conforme relatado por CLANCY et al. 1999, várias estratégias foram adotadas para o desenvolvimento e otimização dessa metodologia, incluindo-se avaliação de cada etapa do método, antes de sua validação final pelas duas equipes (um laboratório americano e um laboratório inglês) encarregadas pela USEPA desse trabalho. Importantes inovações introduzidas no Método 1622 foram a seleção do volume de 10L de amostra, utilização de uma cápsula filtrante, anticorpos magnetizados para limpeza da amostra e coloração com o corante nuclear DAPI (diamino-fenil-indol) como critério adicional para confirmação dos ooccistos do parasita. Posteriormente, o desenvolvimento de anticorpos magnetizados para Giardia e Cryptosporidium possibilitaram modificações no Método 1622 para que ambos protozoários pudessem ser determinados simultaneamente resultando no Método 1623. Eles foram utilizados em substituição ao Método ICR para obtenção de dados mais confiáveis sobre a ocorrência dos protozoários, no programa da USEPA denominado ICRSS (Information Collection Rule Supplemental Surveys) (CONNELL et al. 2000). Tratam-se de metodos baseados no desempenho e assim são permitidas modificações em cada etapa, desde que sejam realizados os testes e atendidos os critérios de qualidade estabelecidos igualmente como parte dos procedimentos desses métodos. Dessa forma, deve ser comprovado que a modificação introduzida não prejudica o desempenho original. Dentre as inovações possíveis, estudadas por vários pesquisadores incluem-se a utilização de outros tipos de material para filtração das amostras, alterações na velocidade e tempos de centrifugação, na etapa de limpeza com os anticorpos magnetizados e na fase de deteç̧ão dos cistos e oocistos através da microscopia de imunofluorescência, citometria de fluxo e citometria de fase sólida (HSU e HUANG 2000, HSU et al. 2000, PEZZANA et al. 2001, STANFIELD et al. 2000, SIMMONS et al. 2001). A Agência Ambiental Americana também tem avaliado e introduzido modificações nesse método e uma nova versão ("Method 1623: 
Cryptosporidum and Giardia in water by filtration /IMS/FA - USEPA 2001) foi recentemente disponibilizada em sua página na Internet.

\subsection{2 - Limitações das Metodologias de Análise de Giardia sp e Cryptosporidium sp, particularmente com relação à Técnica de Concentração por Floculação com Carbonato de Cálcio associada à Microscopia de Imunofluorescência}

Qualquer que seja a técnica de deteç̧ão utilizada, microscopia de imunfluorescência, citometria de fluxo associada ou não à microscopia de imunofluorescència, técnicas de Biologia Molecular, cultura de celulas ou imunoensaios, é necessária a coleta e concentração de grandes volumes de amostra, uma vez que, os parasitas estão presentes em concentrações bastante baixas nas águas naturais. Para concentração das amostras de água vem sendo utilizada com maior freqüència a filtração, em campo ou no laboratório, através de cartuchos ou membranas de porosidade absoluta de $1 \mu \mathrm{m}$, seguida de centrifugação para reduzir-se adicionalmente o volume de amostra. Além disso, devido à presença de interferentes são necessárias etapas de purificação da amostra normalmente realizadas através de flotação e mais recentemente por separação imunomagnética. Em nosso trabalho, foi utilizada o ensaio de imunofluorescência e a concentração das amostras foi realizada através da técnica de floculação com carbonato de cálcio, segundo VESEY et al. 1993. Esses autores, que desenvolveram esse método de concentração para a detecção de oocistos de Cryptosporidium, relataram porcentagens de recuperação superiores a $68 \%$ para os três tipos de água utilizados na pesquisa, mas citam como desvantagem dessa técnica. o fato de ocorrer a concentração de material particulado de vários tamanhos, em quantidades superiores àquelas resultantes através da filtração. Ainda segundo esses pesquisadores, trata-se de uma técnica de concentração simples, robusta e econômica, que requer poucos equipamentos e é igualmente menos trabalhosa que as técnicas de filtração. SHEPHERD e WYN-JONES 1996, avaliando vários métodos para a detecção simultânea de cistos de Giardia e oocistos de Cryptosporidium 
da água, obtiveram porcentagens de recuperação de 72,5 a 77\% para Giardia e 71,3 a $73,6 \%$ para o Cryptosporidium com essa técnica. Para FRICKER e CRABB 1998, as taxas de recuperação que podem ser obtidas através da floculação com carbonato de cálcio, săo entretanto mais baixas, de $30-40 \%$, esse fato tendo sido demonstrado por alguns experimentos nos quais as amostras foram contaminadas com oocistos "estressados ambientalmente" e deixados por alguns dias em contato com água. Trata-se, efetivamente, de acordo com nossa experiência, de uma metodologia que possui várias características positivas : várias amostras podem ser processadas ao mesmo tempo, o que não é possivel no caso da filtração através de cartuchos ou membrana, ou ainda através da técnica de dissolução da membrana (ALDOM e CHAGLIA 1995), que também já foi empregada em nosso laboratório. Deve-se citar como uma vantagem adicional dessa técnica, a possibilidade de recebimento das amostras e seu processamento imediato, mesmo ao final do periodo de trabalho do laboratório, uma vez que a etapa inicial da concentração através de floculação com carbonato de cálcio é bastante simples e rápida, e é seguida de um periodo de manutenção do material a pH 10,0 durante 4 a 10 horas. Ainda em comparação à técnica de filtração, elimina-se uma etapa na qual podem ocorrer perdas importantes dos cistos e oocistos, isto é a separação dos mesmos do material filtrante Também em nossa opinião entretanto, é muito grande a quantidade de material particulado produzido, o que dificulta a observação microscópica e portanto a correta identificação dos cistos e oocistos dos protozoários. Além disso, essa quantidade de material particulado resulta na produção de maiores quantidades de "pellet" após a etapa de centrifugação, e, em conseqüência, é menor a proporção de amostra concentrada observada ao microscópio, e portanto maior o erro devido à extrapolação. YOUNG e KOMISAR 1999 analisaram a variabilidade resultante da análise microscópica parcial do "pellet" produzido através do método ICR, concluindo que, dependendo da distribuição dos cistos e oocistos na amostra, esse procedimento pode aumentar em várias ordens de magnitude o intervalo de confiança das concentrações obtidas. $O$ volume de amostra $(10-20 \mathrm{~L})$ que pode ser analisado é igualmente um fator limitante, conforme apontado por CLANCY e FRICKER 1999. Ainda segundo esses autores, a elevação do $\mathrm{pH}$ a 10 pode ter um efeito deletério nesses organismos. 
HOFFMAN et al. 1999, avaliando quatro preparações de anticorpos para Giardia e Cryptosporidium disponiveis comercialmente, observaram uma fluorescência menos intensa, na citometria de fluxo, após concentração de oocistos não-estressados pela técnica de floculação com carbonato de cálcio. Na observação microscópica, somente duas dessas preparações resultaram em menor coloração, embora fosse visivel certa não uniformidade na fluorescência, como se parte da parede dos oocistos tivesse sido retirada. Os cistos não estressados de Giardia não apresentaram alterações no padrão de fluorescència. Esses autores acreditam que essas alterações devem-se aos extremos de pH aos quais são submetidos os protozoários na técnica de concentração através de floculação com carbonato de cálcio.

Mesmo levando-se em conta essas limitações, vários autores vem utilizando essa técnica de concentração, possivelmente devido à sua praticidade, em associação à microscopia de fluorescència para deteç̧ão dos protozoários em amostras de água, podendo ser citados HUTTON et al. 1995, ZUCKERMAN et al. 1997, HO e TAM 1998, THURMAN et al. 1998, DLAS JÚNIOR 1999, MULLER 1999, RÉ 1999, FARIAS 2000, SKERRET E HOLLAND 2000.

No que diz respeito à deteç̧ão através da microscopia por imunofluorescência, são fatores limitantes o fato de não serem disponiveis anticorpos fluorescentes especificos para Giardia lamblia e (ryptosporidium parvum, portanto o cisto ou oocisto detectado pode pertencer a uma especie não patogènica para humanos. Ainda, não há informação sobre a sua viabilidade. Outra limitação importante é a dificuldade no reconhecimento dos parasitas, pois devido a fatores ambientais adversos, os protozoários podem apresentar-se alterados morfologicamente. Assim, essa etapa da metodologia, além de trabalhosa e demorada, tem um forte componente subjetivo, dependendo inteiramente da experiência dos técnicos. Particularmente nesse trabalho, a detecção dos parasitas nessa etapa foi feita unicamente com base no tamanho e características de fluorescência da Giardia sp e Cryptosporidium sp, uma vez que não era disponivel em nosso laboratório um microscópio equipado com contraste de fase diferencial e interferencial de Normaski (DIC) que possibilitasse a confirmação das caracteristicas morfológicas internas, conforme já determinava o método ICR. Nos métodos 1622 e 1623, foi incluída a 
utilização do corante nuclear DAPI para visualização de estruturas internas dos cistos e oocistos como critério adicional ao DIC para confirmar-se sua identificação. A presença de algas nas amostras concentradas, que reagem positivamente com os anticorpos fluorescentes para Giardia sp e Cryptosporidium sp são apontadas por vários autores como um fator que também pode interferir na identificação correta dos protozoários (RODGERS et al. 1995, FRICKER e CRABB 1998, CLANCY 2000, MCCUIN et al. 2001). As dificuldades na identificação dos cistos e oocistos são também discutidas por SMITH e HAYES 1997, num trabalho sobre o status dos métodos de determinação desses protozoários em utilização no Reino Unido. Esses autores citam a presença de resíduos, a ausència de estruturas internas identificáveis, ou a perda das mesmas devido a fatores ambientais adversos. Eles contestam um critério utilizado por vários pesquisadores como confirmativo para o Cryptosporidium, isto é, um dobramento da superficie da parede do oocisto, destacada pela imunofluorescência. Para eles, esse dobramento é um artefato reversivel, dependente da força osmótica do meio no qual se encontram os organismos, uma vez que os oocistos submetidos à flotação com sacarose apresentam essa característica, que não é mais observada após sua transferência para água destilada.

\subsection{3 - Importância do Controle de Qualidade nas Análises de Giardia sp e Cryptosporidium sp}

Tendo em vista a complexidade dos métodos de análise de Giardia sp e Cryptosporidium $\mathrm{sp}$, ao grande número de etapas necessárias para sua realização e às dificuldades e à-subjetividade na identificação microscópica dos protozoários, é primordial a implantação de um rigoroso programa de controle de qualidade analítica pelos laboratórios. Além da preparação de Procedimentos Operacionais Padronizados detalhados sobre a execução do método, de outros documentos e registros utilizados rotineiramente nos procedimentos de controle de qualidade utilizados em análises microbiológicas, é fundamental uma avaliação do desempenho do laboratório na 
execução dessa análise, que é realizada através da determinação das porcentagens de recuperação de cistos e oocistos dos parasitas a partir da amostras artificialmente contaminadas ("spike").

O método ICR (USEPA 1995) já determinava a realização de controles negativos e positivos para a realização das análises dos protozoários. Para o controle negativo um cartucho filtrante deveria ser processado semanalmente, como se uma amostra tivesse sido filtrada, cistos e oocistos não devendo ser detectados ao final do ensaio. $O$ controle positivo deveria igualmente ser realizado semanalmente, processando-se, através do método ICR, volumes de 40L de água destilada ou de torneira contaminada com 1.000 cistos de Giardia e 2.000 oocistos de Cryptosporidium. Os critérios de aceitação eram relativamente simples, ou seja, cistos e oocistos deveriam ser detectados ao final do ensaio, sem nenhuma exigência quanto à quantificação dos mesmos

Nos métodos 1622 e 1623 (USEPA 1998b, 1999) todo um capítulo é dedicado ao Programa de Controle de Qualidade Analítica que cada laboratório que utiliza o método deverá estabelecer e realizar. Neste Programa incluem-se instruções detalhadas para determinação do desempenho do laboratório na execução das análises, isto é, a porcentagem de recuperação de cistos e oocistos que está sendo obtida, deve ser determinada. Os critérios de aceitação para a porcentagem de recuperação e desvio padrão relativo máximo ( 4 amostras preparadas com água purificada devem ser analisadas) são de $17-100 \%$ e $41 \%$, para Giardia e $21-100 \%$ e 40 para o Cryptosporidium. Posteriormente, o laboratório deverá realizar os controles positivos também em amostras de água, de origem semelhante àquelas normalmente analisadas em rotina. Recomenda-se também, quando possível, a análise de amostras externas de controle de qualidade e a participação do laboratório em estudos interlaboratoriais.

Um fator extremamente importante na avaliação das porcentagens de recuperação é a origem e qualidade dos cistos e oocistos utilizados para a preparação dos controles positivos. Numa revisão de 200 trabalhos sobre análises de Cryptosporidium, KLONICKI et al. 1997, verificaram que apenas 5 autores documentaram parcialmente a fonte, idade, forma de conservação e técnicas de contagens das suspensões de oocistos 
utilizadas para esse objetivo. Eles avaliaram as diferenças de três diferentes técnicas utilizadas para contagens das suspensões de oocistos, ou seja, o hematocitômetro, membranas de acetato de celulose e a contagem direta em lâminas. A validação do Método 1622 foi realizada com suspensões viáveis de oocistos de Cryptosporidium e segundo CLANCY et al. 1999 trata-se de uma escolha importante, uma vez que oocistos viáveis e não viáveis tèm comportamento diferente, sendo importante a otimização de um método que possa recuperar eficientemente os oocistos viáveis. Também para FRICKER e CRABB 1998, embora a maioria das pesquisas relate as porcentagens de recuperação obtidas, não há praticamente informação sobre a qualidade da água utilizada, idade dos oocistos e o periodo de tempo no qual eles estiveram em contato com a água.

$\dot{E}$ igualmente importante o estabelecimento de programas de controle de qualidade analitica no desenvolvimento de novos métodos para análise dos protozoários. Segundo MEINHARDT et al. 1996, essas análises devem ser realizadas em laboratórios que participem de programas internos e externos de controle de qualidade. Também de acordo com CLANCY e FRICKER 1999, poucos dos novos métodos em desenvolvimento foram adequadamente validados, e a maior parte dos experimentos foi realizada em um único laboratório, sendo necessários ensaios inter-laboratoriais para avaliar sua eficácia e identificar suas deficiências. Para LINDQUIST 1999 a grande quantidade de métodos e componentes de métodos (como por exemplo altemativas para amostragem, concentração, limpeza das amostras) que vem sendo proposta, com o objetivo de aperfeiçoar a análise desses protozoários, deve ser submetida a uma avaliação de seu desempenho baseada em critérios técnicos bem definidos, para que os resultados possam ser comparados. Ele propõe que o desempenho deve ser testado num determinado tipo de água, com uma população de cistos e oocistos definida, em determinada concentração, que é por sua vez obtida utilizando-se um uma técnica padronizada de contagem. A partir desse teste, o método em avaliação recebe notas, de 0 a 4, para parâmetros estatísticos de seu desempenho, isto é, a sua porcentagem de recuperação, limite de detecção, precisão, especificidade, etc. 


\section{5 - Resultados das Análises de Giardia sp e Cryptosporidium sp e a Legislação Nacional e Internacional sobre os Protozoários de Veiculação Hídrica}

Conforme já relatado detalhadamente na Introdução desse trabalho, a legislação americana foi a primeira a estabelecer regras e medidas de controle para a presença desses organismos na água. Igualmente nesse país, através da Agência Ambiental Americana, foi promulgado o maior número de instrumentos legislativos referentes a esses contaminantes. Isto porque, o "Science Advisory Board" da USEPA (um grupo independente de especialistas no assunto, criado pelo congresso americano), considera que a exposição a contaminantes microbianos, bactérias, vírus e protozoários (Giardia lamblia e (ryptosporidium) representa o mais sério risco para a saúde, permanecendo o maior desafio para as empresas de abastecimento de água. Assim, através da "Surface Water Treatment Rule", "Enhanced Surface Water Treatment Rule" e "Long Term Enhanced Surface Water Treatment Rule" (USEPA 1989, 1998 e 2000) foram estabelecidas metas, não legalmente obrigatórias, de ausência desses protozoários na água tratada. Entretanto, as medidas mais importantes dessas leis referem-se à adoção de técnicas de tratamento de água mais eficientes para esses microrganismos patogênicos. Entre essas regras incluem-se graus de inativação/remoção, limites para turbidez e eficiência dos filtros.

Quanto ao Brasil, uma legislação recente do Ministério da Saúde, a Portaria 1469 de 29 de dezembro de 2000 (MINISTÉRIO DA SAÚDE 2000) que estabelece os padrões de potabilidade para água de consumo humano, recomenda a análise desses protozoários e de enterovírus na água, com o objetivo de atingir-se um padrão de ausência para os mesmos. São também determinados padrões de turbidez em complementação aos padrões de qualidade microbiológica da água, especialmente para assegurar-se a remoção eficiente de cistos de Giardia spp e Cryptosporidium sp. A recomendação constante dessa Portaria, para as análises desses protozoários refere-se a águas provenientes do sistema de abastecimento ou de solução alternativa de abastecimento de água para consumo humano, esses sistemas sendo definidos pela Portaria. Seu artigo 9 
determina que cabe ao responsável pela Operação do Sistema e/ou Solução Alternativa, em conjunto com os órgãos ambientais, entre outros procedimentos, efetivar o controle das caracteristicas dos mananciais de abastecimento e da bacia contribuinte. Ainda segundo o Artigo 19 dessa Portaria, essas análises deverão contemplar os paràmetros exigidos na legislação vigente de classificação e enquadramento de águas superficiais, avaliando a compatibilidade entre as características da água bruta e o tipo de tratamento. Trata-se da Resolução CONAMA 20/86 (CONAMA 1986) que classifica as águas doces, salobras e salinas de acordo com paràmetros e indicadores especificos, os coliformes fecais sendo adotados no que diz respeito à qualidade microbiológica. Embora essa legislação considere ainda para essa classificação teores máximos de uma série de substàncias potencialmente prejudiciais, que devem ser investigadas sempre que houver suspeita de sua presença, não há qualquer menção à necessidade de investigação da presença de microrganismos patogênicos, em qualquer situação.

Assim, pode-se dizer que as análises realizadas nesse trabalho atenderam. parcialmente, a uma legislação americana, a denominada Legislação de Monitoramento , a "Information Colletcion Rule" - ICR (USEPA 1996), no que diz respeito ao monitoramento de Giardia, Cryptosporidium e coliformes fecais . Segundo o ICR, esse monitoramento deveria ser realizado por sistemas produtores especificados nessa lei, mensalmente, durante 18 meses. Nesse monitoramento eram também incluidos vírus totais cultiváveis e coliformes totais. Ainda segundo essa lei, caso o sistema produtor detectasse, nas águas de captação, concentrações iguais ou superiores a 10 cistos de Giardia, ou 10 oocistos de Cryptosporidium por litro (ou mais de 1 vírus cultivável por litro), em qualquer um dos primeiros doze meses de monitoramento, deveria também coletar amostras de água tratada mensalmente, iniciando-se essas coletas no $1^{\circ}$ mês após a obtenção desse resultado. Nessas amostras de água deveriam ser realizadas as mesmas análises requeridas para as águas de captação, isto é, coliformes totais, coliformes fecais, Giardia, Cryptosporidium e virus totais cultiváveis. Esse monitoramento da água tratada deveria ser igualmente mantido por 18 meses. Se os critérios do ICR fossem aplicados para os resultados obtidos nos 28 pontos de captação avaliados nesse trabalho, seria 
necessário realizar-se o monitoramento da água tratada nos 16 pontos relacionados na Tabela 24 abaixo:

Tabela 24 - Pontos de captação nos quais foram detectadas concentrações superiores a 10 cistos/L de Giardia sp ou 10 oocistos/L de Cryptosporidium $\mathrm{sp}$

\begin{tabular}{cc}
\hline UGRHI & PONTO DE CAPTAÇ̃̃o \\
\hline 02 - Paraiba do Sul & R. Paraiba na captação da SABESP. em Tremembé \\
R. Paraiba, na captação de Jacareí \\
\hline 05 - Piracicaba, & $\begin{array}{c}\text { R.Piracicaba, na captação de água de Americana, em Cariobá } \\
\text { R. Piracicaba, margem esquerda, na captação de Piracicaba } \\
\text { Rapivari, Jundiaí }\end{array}$ \\
R. Capivari, na captação da ETA 4 de Campinas \\
R. Atibaia, na captação de Atibaia \\
\hline 06 - Alto Tietè & R. Tietê, na captação principal de Mogi das Cruzes \\
& Reservatório do Guarapiranga, na captação da SABESP \\
R. Cotia, na captação da ETA do Cotia Baixo \\
Ribeirão dos Cristais, na captação da ETA de Cajamar \\
\hline 07 - Baixada Santista & R. Cubatão, em frente à antiga ETA do rio Cubatão \\
& Reservatório do Capivari Monos, estação de recalque da \\
$09-$ Mogi-Guaçú & R. Mogi-Guaçú, na ETA da Acad. Força Aérea \\
\hline 17 - M. Paranapanema & R. Pardo, ponte rodovia Raposo Tavares, Km 381 \\
\hline 21 - Peixe & R. do Peixe, ponte na rodovia que liga Marília a Assis \\
\hline
\end{tabular}

Considerando, entretanto a importância atual desses protozoários como agentes de doenças de veiculação hídrica, tendo em vista a elevada ocorrência de surtos dessas doenças na América do Norte e Reino Unido, a CETESB decidiu incluir, desde 1999, essas análises nos 28 pontos de captação pertencentes à Rede de Monitoramento de Qualidade das Águas Interiores do Estado de São Paulo, que são coincidentes com captações utilizadas para abastecimento público. $\mathrm{O}$ objetivo desse monitoramento era obter um diagnóstico da ocorrência desses protozoários nas águas superfíciais destinadas 
ao abastecimento público, que implicam em risco à saúde humana, caso o tratamento não seja eficiente na sua remoção (CETESB 1999).

\section{6 - Utilização dos Resultados das Análises de Giardia sp e Cryptosporidium sp em Saúde Pública}

A principal limitação à utilização dos resultados das análises de Giardia sp e Cryptosporidum sp em Saúde Pública refere-se a defíciências na metodologia dessas análises. Alguns desses problemas são entretanto comuns às análises de outros microrganismos patogênicos na água, e vem sendo amplamente discutidos por diversos autores, devido à importância desses protozoários como agentes de doenças de veiculação hidrica

Numa revisão sobre os aspectos epidemiológicos da criptosporidiose humana e o papel da transmissão hídrica, MEINHARDT et al. 1996 discutem os problemas associados à concentração e distribuição dos protozoários patogênicos na água. Segundo esses autores, as amostras ambientais representam uma simples "fatia" de uma "curva de distribuição" dos oocistos no corpo d'água e sua dispersão no mesmo não é homogênea. Amostras de água coletadas durante um surto ou um monitoramento de rotina raramente irão coincidir com o "pico" dessa curva, e assim a avaliação numérica desses resultados com objetivo de avaliação de risco para Saúde Pública é atualmente inviável. Para os autores, também devido aos problemas metodológicos particulares a essas análises, já discutidos anteriormente (impossibilidade em determinar-se a viabilidade, patogenicidade, virulência e espécie) as autoridades sanitárias devem ter cautela na interpretação dos resultados, principalmente pelas consequências que medidas tais como a recomendação para fervura da água podem ter. Deve-se também reconhecer que em vários surtos da doença, o Cryptosporidium foi identificado primeiramente na população antes de ser detectado, retrospectivamente, nos casos em que essa detecção ocorreu, na água suspeita. 
Para CRAUN et al. 1997, além do monitoramento microbiológico (através de indicadores ou microrganismos patogênicos) são necessárias medidas adicionais para proteção contra as doenças de veiculação hídrica. Segundo esses autores, é igualmente importante proteger-se a fonte através, por exemplo, do controle de lançamentos, e também adequar-se o tratamento da água

Também para SMITH e ROSE 1998, ETAs operando eficientemente podem controlar o Cryptosporidium, mas as águas brutas devem ser monitoradas sempre que ocorram alterações significativas na sua qualidade, ou quando a ETA não estiver operando em condições normais. Esse monitoramento deve ser intensificado na ocorrência de surtos de doenças de veiculação hidrica.

Num levantamento realizado por CLANCY e HANSEN 1999, foram enviados questionários a sistemas de abastecimento e agências reguladoras, na América do Norte e Europa. $\mathrm{O}$ intuito era obter informações sobre o monitoramento dos protozoários e objetivos do mesmo. De acordo com as respostas, os dados desse monitoramento eram utilizados para avaliar a eficiência do tratamento e fornecer subsidios para o planejamento de investimentos. Raramente esses resultauios eram usados para decisões em Saúde Pública, e nesses casos, apenas com o auxilio de outras informações, como por exemplo, alterações meteorológicas na bacia, dados sobre o tratamento da água (tais como a turbidez) ou sobre a ocorrência de doença na comunidade.

SINCLAIR et al. 1998 e FAIRLEY et al. 1999 também expõem as razões pelas quais o monitoramento isoladamente não responde a todas as questões e propõem novas estratégias.

A utilização e relevância dos resultados dessas análises em Saúde Pública, começou a ser contestada com mais veemência entretanto, a partir de um episódio ocorrido em 1998, em Sydney, na Austrália. Conforme relatado por CLANCY 2000, elevadas concentrações de oocistos de Cryptosporidium e cistos de Giardia foram detectados repetidamente em amostras de água coletadas no sistema de distribuição, embora não tivesse sido observado qualquer aumento na incidência de doenças de veiculação hidrica. As concentrações observadas variavam de não-detectado a milhares de parasitas por $100 \mathrm{~L}$ de água. Com base nesses resultados, foram emitidos 3 avisos para ferver a 
água, num período de 9 semanas. $\mathrm{O}$ governo determinou um inquérito formal para averiguar a causa da contaminação. A autora visitou as instalações envolvidas e descobriu que os dados do monitoramento tinham sérios problemas de controle de qualidade, tornando-os suspeitos. Além disso, outros laboratórios demonstraram que os relatórios originais tinham erros. Em sua opinião, a confiança em dados de monitoramento que não tinham a qualidade desejada geraram a crise, quando de fato, não haviam problemas na qualidade da água ou ameaças à saúde pública.

A opinião de ALLEN et al. 2000, numa revisão detalhada sobre os problemas associados à detecção dos protozoários Giardia e Cryptosporidium na água de consumo humano, incluindo o episódio de Sydney, e outros, é bastante radical. Para eles, o monitoramento de microrganismos patogênicos não pode confirmar a presença ou ausência absoluta de microrganismos infecciosos na água de consumo humano, a solução residindo na otimização dos processos de tratamento e na proteção da fonte, bem como em outras medidas que assegurem a integridade do sistema. Os microbiologistas deveriam trabalhar no sentido de fornecer instrumentos práticos para medir-se a eficiência dos processos de tratamento da água, ao invés de desenvolver metodologias para o monitoramento de microrganismos patogênicos.

Apesar entretanto dessas opiniões contrárias, novas técnicas para detecção dos parasitas Giardia sp e Cryptosporidium sp continuam a ser desenvolvidas e seu monitoramento em amostras ambientais, principalmente em águas brutas e tratadas, prossegue em vários países. Para ROSE et al. 2002, num trabalho de revisão sobre risco e controle da criptosporidiose, o monitoramento com essas novas metodologias irá permitir uma melhor avaliação da ocorrência da doença em níveis endêmicos e igualmente a determinação das fontes e causas dos surtos, informações que poderão ser usadas para minimizar sua transmissão através da água.

Não concordamos com a posição de alguns pesquisadores contrários mesmo a pesquisas para desenvolvimento de metodologias mais aperfeiçoadas para a detecção de microrganismos patogênicos em águas, em especial no que diz respeito à Giardia sp e ao Cryptosporidium sp. Acreditamos certamente que os resultados obtidos no monitoramento desses protozoários devam ser interpretados com cautela e utilizados 
com critério para decisões importantes na área de Saúde Pública., principalmente levando-se em consideração as limitações que mesmo os métodos mais avançados apresentam. Esperamos igualmente que os resultados descritos nesse trabalho, respeitadas suas deficiências, venham contribuir, de alguma forma, para a melhoria da qualidade das águas captadas para consumo humano no Estado de São Paulo. 


\section{7 - CONCLUSÕES}

De acordo com os resultados das análises de Giardia sp, Cryptosporidium sp e dos indicadores de contaminação fecal realizadas em 28 pontos de captação de 10 bacias hidrográficas do Estado de S. Paulo, de janeiro de 1999 a setembro de 2000, e do estudo das relações entre as concentrações dos protozoários e bactérias pode-se concluir que

- Em comparação com dados da literatura, os resultados da análise dos protozoários Giardia sp e Cryptosporidium $\mathrm{sp}$ demonstraram baixa porcentagem de amostras positivas para esses dois parasitas patogênicos, principalmente para o Cryptosporidium $\mathrm{sp}$ As concentrações observadas foram similares àquelas relatadas por outros pesquisadores em águas superficiais.

- Deve ser mencionado que alguns pontos de captação apresentaram elevadas porcentagens de amostras positivas para Giardia sp, em altas concentrações, durante todo o período de estudo. Tratam-se dos pontos de captação localizados nos rios Piracicaba e Atibaia na UGRHI 05 - Piracicaba, Capivari, Jundiaí, e dos pontos de captação localizados no rio Cotia, ETA do Cotia Baixo, e no Ribeirão dos Cristais,.ETA de Cajamar na UGRHI 06 Alto Tietê.

- Foi observada uma correlação significativa (Teste de Correlação de Spearman) entre as concentrações de Giardia sp e as bactérias de contaminação fecal, coliformes fecais, estreptococos fecais e Clostridium perfringens. Essa correlação significativa, que foi verificada para a totalidade dos resultados e para algumas UGHRIs, pode ser explicada pela extrema variação de qualidade observada nos 28 pontos de captação estudados e pela excelente concordância entre qualidade bacteriológica e as porcentagens de amostras positivas e concentrações da Giardia sp. Ainda, como a técnica de análise utilizada possuia, muito possivelmente, baixa recuperação, não foram detectados parasitas nos corpos d'água que apresentavam melhor qualidade e nos quais as concentrações dos mesmos eram provavelmente mais baixas. 
- No que diz respeito à legislação, apesar da existência da recente Portaria 1469/2000 do Ministério da Saúde, que determina os padrões de qualidade para águas de consumo humano e recomenda a análise dos protozoários Giardia sp e Cryptosporidium sp na água tratada, não existe nenhuma regulamentação nacional que estabeleça o monitoramento desses protozoários ou de quaisquer outros microrganismos patogênicos em águas a serem captadas para consumo hümano. A legislação americana, através da sua Agência de Proteção Ambiental, estabeleceu uma legislação de monitoramento, a chamada ICR (Information Collection Rule) para Giardia sp e Cryptosporidium sp, dentre outros microrganismos. Analisando-se os resultados obtidos nesse trabalho à luz dessa regulamentação, verifica-se que para 16 dos 28 pontos de captação estudados, localizados em 7 UGRHIs, seria requerida a análise da água tratada, com o objetivo de avaliar se o tratamento está sendo eficaz para a remoção desses parasitas.

- Do ponto de vista da metodologia, em virtude da complexidade das técnicas de análise desses protozoários, em especial para o ensaio de imunofluorescência, devido ao forte componente subjetivo envolvido na identificação microscópica dos microrganismos, é fundamental a implementação de um rigoroso Controle de Qualidade Analítica pelos laboratórios que a realizam. Finalmente, é importante acrescentar que embora os métodos para detecção dos protozoários patogênicos Giardia sp e Cryptosporidium sp tenham apresentado um notável desenvolvimento nos últimos anos possuindo atualmente maior sensibilidade, especificidade $\mathrm{e}$ principalmente permitindo melhor quantificação desses microrganismos, deficiências significativas ainda dificultam sua realização. A técnica de imunofluorescência, utilizada nesse trabalho, e igualmente na maior parte das pesquisas realizadas no Brasil e em outros paises do mundo, não permite a determinação da espécie e viabilidade do parasita detectado, o que limita de forma significativa a utilização dos resultados obtidos, principalmente para decisões em Saúde Pública. Essas deficiências, entretanto, não devem ser justificativa para que o monitoramento ambiental desses protozoários patogênicos deixe de ser realizado 


\section{REFERÊNCIAS}

Aldom JE, Chaglia AH. Recovery of Cryptosporidium oocysts from water by a membrane filter dissolution method. Letters Appl Microbiol 1995, 20:186-187.

Allen MJ, Clancy JL, Rice EW. The plain, hard truth about pathogen monitoring. J Am Water Works Assoc 2000, 92(9):64-76

AMERICAN PUBLIC HEALTH ASSOCIATION. Microbiological Examination. In: Standard Methods for the Examination of Water and Wastewater. $20^{\text {th }}$ ed APHA, AWWA, WEF, Washington, 1986.

AMERICAN PUBLIC HEALTH ASSOCIATION. Microbiological Examination. In: Standard Methods for the Examination of Water and Wastewater. $19^{\text {th }}$ ed APHA, AWWA, WEF, Washington, 1995.

AMERICAN PUBLIC HEALTH ASSOCIATION. Microbiological Examination. In: Standard Methods for the Examination of Water and Wastewater. $20^{\text {th }}$ ed APHA, AWWA, WEF, Washington, 1998.

Atherholt TB, LeChevalier MW, Norton WD, Rosen JS. Effect of rainfall on Giardia and Crypto. J Am Water Works Assoc 1998; 90 (9): 66-80.

Atherholt TB, Korn, LR. ICR Protocol: Alternative treatment of parasite sample data J Am Water Works Assoc 2000, 91(3): 95-102

Barwick RS, Levy DA, Craun GF, Beach MJ, Calderon RL. Surveillance for waterborne disease outbreaks - United States. 1997-1998. MMWR 2000, 49(SS-4) $1-35$ 
Bukhari Z, Smith HV, Skyes N, Humphreys SW, Paton CA, Girdwood RWA, Fricker CR. Occurrence of Cryptosporidium spp oocysts and Giardia sp cysts in sewage influents and effluents from treatment plants in England. Water Sci Technol 1997, 35(11-12): 385-390.

Call JL, Arrowood M, Xie LT, Hancock K, Tsang VC. Immunoassay for viable Cryptosporidium parvum oocysts in turbid environmental water samples. J Parasitol 2001, 87(1): 203-210.

Carraro E, Fea E, Salva S, Gilli G. Impact of a wastewater treatment plant on Cryptosporidium oocysts and Giardia cysts occurring in a surface water. Water Sci Technol 2001, 41(7):31-37.

Casemore DP, Sands RL, Curry A. Cryptosporidium species a "new" human pathogen. J Clin Pathol 1985, 38: 1321-1336.

Casemore DP. Epidemiological aspects of human cryptosporidiosis. Epidemiol Infect 1990, 104: 1-28.

Craun GF. Waterborne giardiasis in the United States 1965-84. Lancet 1986, 2: 513514.

CETESB. Estreptococos fecais - Determinação do número mais provável pela técnica de tubos múltiplos. São Paulo, 1984 (NT L5.205).

CETESB. Clostridium perfringens - Determinação em amostras de água pela técnica de tubos múltiplos - Método de ensaio. São Paulo, 1992 (NT L5. 213).

CETESB. Coliformes fecais - determinação em amostras de água pela técnica de tubos múltiplos - método de ensaio. São Paulo, 1993 (NT L5.406). 
CETESB. Relatório de qualidade das águas interiores do estado de São Paulo 1999. São Paulo: CETESB, 2000.

CETESB. Relatório de qualidade das águas interiores do estado de São Paulo 2000. São Paulo: CETESB, 2001.

Chauret C, Armstrong N, Fisher J, Sharma R, Springthorpe S, Sattar S. Correlating Cryptosporidium and Giardia with microbial indicators. J Am Water Works Assoc $1995,87(11) 76-84$.

Clancy JL, Hansen J. Uses of protozoan monitoring data. J Am Water Works Assoc 1999, 91(5):51-65.

Clancy JL, Fricker CR. Giardia and Cryptosporidium methods for water testing current status and future needs. Water Supply 1999, 17(2):49-55.

Clancy JL, Bukhari Z, McCuin RM, Matheson Z, Fricker CR. USEPA Method 1622 J Am Water Works Assoc 1999, 91(9): 60-68.

Clancy JL. Sydney's 1998 water quality crisis. J Am Water Works Assoc 2000, 92(3): 55-66.

Connell K, Rodgers CC, Shank-Givens HL, Scheller J, Pope ML, Miller K. Building a better protozoa data set. J Am Water Works Assoc 2000, 92(10):30-43.

Conselho Nacional do Meio Ambiente. Resolução Conama $n^{\circ} 20$, de 18 de junho de 1986. Dispõe sobre a classificação das águas doces, salobras e salinas, segundo seus usos preponderantes, em todo o território nacional. Disponivel em URL [ http://www.mma.gov.br/port/CONAMA/res/res86/res2086.html] [09/04/00].

Craun GF. Waterborne giardiasis in the United States 1965-1984. Lancet 1986, 2 $513-514$ 
Craun GF, Berger, PS, Calderon RL. Coliform bacteria and waterborne disease outbreaks. J Am Water Works Assoc 1997, 89(3): 96-104.

Dias Júnior O. Ocorrência de cistos de Giardia sp e oocistos de Cryptosporidium spp em águas superficiais e esgoto no município de Araras - SP. São Paulo; 1999. [Dissertação de Mestrado - Universidade Mackenzie]

Dupont H, Chappel CL, Sterling CR, Okhhuysen PC, Rose JB, Jabukowski W. The infectivity of Cryptosporidium parvum in healthy volunteers. New Engl J Med, 1995, 332(13): 855-859

Enriquez V, Rose JB, Enriquez CE, Gerba CP. Occurrence of Cryptosporidium and Giardia in secondary and tertiary wastewater effluents. In: Betts WB et al. editors. Protozoan Parasites and Water, Cambridge: Royal Society of Chemistry; 1995, p. 84-86

Farias EVC. Detecção de oocistos de Cryptosporidium spp em águas de abastecimento superficiais e tratadas da região metropolitana de São Paulo. São Paulo; 2000. [Dissertação de Mestrado - Instituto de Ciências Biomédicas da USP]

Fairley CK, Sinclair MI, Rizak S. Monitoring not the answer to cryptosporidium in water. Lancet 1999, 354 (September): 967-968

Fayer R, Morgan U, Upton SJ. Epidemiology of Cryptosporidium: transmission, detection and identification. Int J Parasitol 2000, 30: 1305-1322.

Franco RM, Rocha-Eberhardt R, Cantusio Neto R. Occurrence fo Cryptosporidium oocysts and Giardia cysts in raw water from the Atibaia river, Campinas Brazil. Rev Inst Med Trop S Paulo 2001, 43(2):109-111

Fricker CR, Crabb J. Water-borne Cryptosporidiosis: Detection methods and treatment options. Adv Parasitol. 1998, 40:241-278. 
Frost FJ, Craun GF, Calderon RL. Waterborne disease surveillance. J Am Water Works Assoc 1996, 88(9): 66-75

Furness BW, Beach MJ, Roberts JM. Giardiasis surveillance - United States, 19921997.MMWR 2000, 49(SS07):1-13

Furtado C, Adak GK, Stuart JM, Wall PG, Evans HS, Casemore DP. Outbreaks of waterborne infectious intestinal disease in England and Wales, 1992-5. Epidemiol Infect 1998, 121: 109-119

Gennari-Cardoso ML, Costa-Cruz JM, Castro E Lima LMFS, Prudente DV. Cryptosporidium $\mathrm{sp}$ in children suffering from acute diarrhea at Uberlândia city, State of Minas Gerais, Brazil. Mem Inst Oswaldo Cruz 1996, 91(5): 551-554.

Gibson CJ, Stadterman KL, States S, Sykora J. Combined sewer overflows: a source of Cryptosporidium and Giardia? Water Sci Technol. 1998a, 38(12): 67-72.

Gibson CJ, Haas CN, Rose JB. Risk assessment of waterborne protozoa: current status and future trends. Parasitology 1998b, 117: S205-212.

Gofti L. Zmirou D, Murandi FS, Hartemann PH, Potelon JL. Evaluation du risque microbiologique d'origine hydrique: un état de l'art et des perspectives. Rev Epidém Santé Publique 1999, 47: 61-73.

Goldstein ST, Juranek DD, Ravenholt O, Hightower AW, Martin DG, Mesnik JL, Griffiths SD, Bryant AJ, Reich RR, Herwaldt BL. Cryptosporidiosis: An outbreak associated with drinking water despite state-of-the-art water treatment. Ann Intern Med 1996, 124(5):459-468

Grimason AM, Smith HV, Thitai WN, Smith PG, Jackson MH, Girdwood RWA. Occurrence and removal of Cryptosporidium spp oocysts and Giardia spp cysts in kenyan waste stabilisation ponds. Water Sci Technol 1993, 27(3-4):97-104. 
Hancock CM, Rose JB, Callahan M. Crypto and Giardia in US groundwater. J Am Water Works Assoc 1998, 90(3): 58-61.

Hashimoto A, Hirata T, Kunikane S. Occurence of Cryptosporidium oocysts and Giardia cysts in a conventional water purification plant. Water Sci Technol 2001, $43(12): 88-92$.

Herwaldt BL, Craun GF, Stokes SL, Juranek DJ. Outbreaks of waterborne disease in the United States: 1989-90. J Am Water Works Assoc 1992, 84(4): 129-135.

Ho BSW, Tam TY. Giardia and Cryptosporidium in sewage-contaminated river waters. Water Res 1998, 32(9): 2860-2864.

Hoffman R, Chauret C, Stanridge J, Peterson L. Evaluation of four commercial antibodies. J Am Water Works Assoc 1999, 91(9): 69-78.

HSMO. The bacteriological examination of water supplies., $5^{\text {th }}$ ed., London, 1977. Department of Health and Social Security Welsh Office. Department of Environment. Reports on public health and medical subjects No. 71.

HSMO. The Water Supply (Water Quality) (Amendment) Regulations 1999.URL http://www.hsmo.gov.uk/si/si19991524htm. 11/11/00.

Hsu BM, Huang C, Hsu CLL, Hsu YF, Yeh JH. Occurrence of Giardia and Cryptosporidium in the Kau-Ping river and its watershed in Southern Taiwan. Water Res 1999, 33(11): 2701-2707.

Hsu BM, Huang C. Recovery of Giardia and Cryptosporidium from water by various concentration, elution and purification techniques. J Environ Qual 2000, 29:15871593. 
Hutton P, Ashbolt N, Vesey G, Walker J, Ongerth J. Cryptosporidium and Giardia in the aquatic environment of Sydney, Australia.. In: Betts WB et al. editors. Protozoan Parasites and Water, Cambridge: Royal Society of Chemistry; 1995, p. 71-75.

Ionas G, Learmonth JJ, Keys EA, Brown TJ. Distribution of Giardia and Cryptosporidium in natural water systems in New Zealand - A nationwide survey. Water Sci Technol. 1998, 38(12): 57-60.

Juranek DD. Cryptosporidiosis: Sources of infection and guidelines for prevention. Centers for Disease Control and Prevention. National Centers for Infectious Diseases. Division of Parasitic Diseases, 1999. Available from:< URL:http://www.cdc.gov/ncidod/dpd/parasites/cryptosporidiosis/crypto_sources_of_ infect.htm

Kappus KD, Lundgren RG Jr, Juranek DD, Roberts JM, Spencer HC. Intestinal parasitism in the United States: update on a continuing problem. Am J Trop Med Hyg 1994, 50(6): 705-713

Karanis P. Schoenen D, Seitz HM. Distribution and removal of Giardia and Cryptosporidium in water supplies in Germany. Water Sci Technol 1998, 37(2): 918.

Klonicki $\mathrm{P}$ et al. Crypto research: are fundamental data missing? J Am Water Works Assoc 1997, 89(9): 97-103

Korich DG, Mead JR, Madore MS, Sinclair NA, Sterling CR. Effects of ozone, chlorine dioxide, chlorine and monochloramine on Cryptosporidium parvum oocyst viability. Appl Environ Microbiol 1990, 56(5): 1423-1428.

Kramer MH. Herwaldt BL, Craun GF, Calderon RL, Juranek DD. Waterborne disease: 1993 and 1994. J Am Water Works Assoc 1996, 88 (3): 66-80. 
Kent GP, Greenspan JR, Herndon JL, Mofenson LM, Harris JAN, Eng TR, Vaskin HA. Epidemic giardasis caused by a contaminated public water supply. Am J Public Health 1988, 78(2): 139-143

LeChevalier MW, Trok TM, Burns MO, Lee RG. Comparison of the zinc sulphate and immunofluorescence techniques for detecting Giardia and Cryptosporidium. $\mathbf{J}$ Am Water Works Assoc 1990, 82(9):75-82

LeChevalier MW, Norton WD, Lee RG. Occurrence of Giardia and Cryptosporidium spp. In surface water samples. Appl Environ Microbiol 1991, 57(9): 2610-2616

LeChevalier MW, Norton WD. Examining relationships between particle counts and Giardia, Cryptosporidium and turbidity. J Am Water Works Assoc 1992, 84(12):54-60

LeChevalier MW, Norton WD. Giardia and Cryptosporidium in raw and finished water. J Am Water Works Assoc 1995, 87(9): 54-68.

LeChevalier MW, Norton W, Atherholt TB. Protozoa in open reservoirs. J Am Water Works Assoc 1997, 89(9):84-96

Leclerc H, Mossel DAA, Edberg SC, Struijk CB. Advances in the bacteriology of the coliform group: their suitability as markers of microbial water safety. Ann Rev Microbiol 2001, 55: 201-234

Lee YM et al. Development and application of a quantitative specific assay for Cryptosporidium parvum oocyst detection in high-turbidity environmental water samples. Am J Trop Med Hyg 2001, 65: 1-9.

Levine WC, Stephenson WT, Craun GF. Waterborne disease outbreaks, 1986-1988. MMWR 1990, 39(SS-1): 1-9 
Levy DA, Bens MS, Craun GF, Calderon RL, Herwaldt BL. Surveillance for waterborne disease outbreaks - United States, 1995-1996. MMWR 1998, 47(SS-5): 1-34.

Lindquist A. Emerging pathogens of concern in drinking water. United States Environmental Protection Agency. 1999, EPA 600/R-99/070.

Lindquist A. (Ed). Criteria for evaluation of proposed protozoan detection methods. United States Environmental Agency. 1999, EPA 815-K-99-02

Ludwig KM, Frei F, Alvares Filho F Ribeiro-Paes JT. Correlação entre as condições de saneamento básico e parasitoses intestinais na população de Assis, Estado de São Paulo. Rev Soc Bras Med Trop 1999, 32(5): 547-555

Mac Kenzie W et al. A massive outbreak in Milwaukee of Cryptosporidium infection transmitted through the public water supply. New Engl J Med 1994, 331(3): 161167.

Magara Y et al. Nationwide survey of Cryptosporidium and Giardia. Water Supply $1999,17(3 / 4): 213-218$.

Mahbubani MH, Bej AK, Perlin M, Schaefer FW, Jakubowski W, Atlas RM Detection of Giardia cysts by using the polymerase chain reaction and distinguishing live from dead cysts. Appl Environm Microbiol 1991, 57: 3456- 3461.

Marshall MM, Naumovitz D, Ortega Y, Sterling CR. Waterborne protozoan pathogens. Clin Microbiol Rev 1997, 10(1): 67-85.

McCuin RM. Bukhari Z, Clancy JL. Recovery and viability of Cryptosporidium parvum oocysts and Giardia intestinalis cysts using the membrane dissolution procedure. Can J Microbiol 2001, 46():700-707 
Medema GJ, Bahar M, Schets FM. Survival of Cryptosporidium parvum, Escherichia coli, fecal enterococci and Clostridium perfringens in river water: influence of temperature and autochthonous microorganisms; Water Sci Technol 1997, 35(11-12): 249-52.

Medema GJ, Schets FM, Ketelaars H, Boschman G. Improved detection and vital staining of Cryptosporidium and Giardia with flow cytometry. Water Sci Technol 1998, 38(12): 61-65.

Meinhardt PL, Casemore DP, Miller KB. Epidemiologic aspects of human cryptospordiosis and the role of waterborne transmission. Epidemiol Rev 1996, 18(2): 118-136.

Ministério da Saúde. Centro Nacional de Epidemiologia. Coordenação Nacional de Doenças Entéricas. Monitorização das doenças diarréicas agudas. Diarréias: Epidemiologia. São Paulo: Centro de Vigilância Epidemiológica, CVE, 1999.

Ministério da Saúde. Portaria No 1469 de 29.12.2000; Estabelece os procedimentos e responsabilidades relativos ao controle e vigilância da qualidade da água para consumo humano e seu padrão de potabilidade, e dá outras providências. URL: www. funasa.gov.br/amb/pdfs/portaria $1469 \mathrm{pdf}$.

Moore AC, Herwaldt BL, Craun GF, Calderon RL, Highsmith AK, Juranek DD. Waterborne disease in the United States, 1991 and 1992. J Am Water Works Assoc 1994, 86(2): 87-99.

Muller APB. Detecção de oocistos de Cryptosporidium spp em águas de abastecimento superficiais e tratadas da região metropolitana de São Paulo. São Paulo; 1999. [Dissertação de Mestrado - Instituto de Ciências Biomédicas da USP]. 
National Health and Medical Research Council. Microbial indicators of water quality An NHMRC Discussion Paper. Public Consultation Draft. Canberra, Austrália. 2001. Available from
[URL: http://www.health.gov.au/nhmrc/adivice/microbe.pdf.] [2001 Oct 23].

Newman RD, Wuhib T, Lima AAM, Guerrant RL, Sears CL. Environmental sources of Cryptosporidium in an urban slum in northeastern, Brazil. Am J Trop Med Hyg $1993,49(2): 270-275$.

Newman RD, Zu S, Wuhib T, Lima AAM, Guerrant RL, Sears CL. Household epidemiology of Cryptosporidium parvum infection in an urban community in northeast, Brazil. Ann Intern Med 1994, 120(6): 500-505.

Ong C, Moorehead W, Ross A, Isaac-Renton J. Studies of Giardia spp. and Cryptosporidium spp. in two adjacent watersheds. Appl Environ Microbiol 1996, 62(8): 2798-2805.

Ortega Y, Adam RD. Giardia: Overview and uptdate. Clin Infect Dis 1997, 25(9): $545-550$

Otterstetter H, Craun G. Disinfection in the Americas: A necessity. J Am Water Works Assoc 1997, 89(9): 8-10.

Payment P, Richardson L, Siemitatycki J, Dewar R, Edwardes M, Franco E. A randomized trial to evaluate the risk of gastrointestinal disease due to consumption of drinking water meeting current microbiological standards. Am J Public Health 1991, 81(6): 703-708.

Payment P, Franco E. Clostridium perfringens and somatic coliphages as indicators of the efficiency of drinking water treatment for viruses and protozoan cysts. Appl Environ Microbiol 1993, 59(8): 2418-2424. 
Payment P, Plante R., Cejka P. Removal of indicator bacteria, human enteric viruses, Giardia cysts, and Cryptosporidium oocysts at a large wastewater primary treatment facility. Can J Microbiol 2001, 47:188-193.

Pedraza-Dias S, Amar C, Nichols GL, McLauchlin J. Nested polymerase chain reaction for amplification of the Cryptosporidium oocyst wall protein gene. Emerg Infect Dis 2001, 7(1): 49-56.

Pezzana A, Villaginès Ph, Bordet F, Coquard D, Sarrette B, Villaginès $R$. Optimization of the Envirocheck capsule method and immunomagnetic separation procedure for the detection of low levels of Cryptosporidium in large drinking water samples. Water Sci Technol 2001, 41(7):111-117.

Pontious FW, Clancy J. ICR Crypto data: worthwhile or worhtless? J Am Water Works Assoc 1999 91(9): 14-22.

Ré AL. Qualidade microbiológica e parasitológica de águas de consumo humano do município de Araras - SP, com ênfase na pesquisa de oocistos de Cryptosporidium sp e cistos de Giardia lamblia. São Paulo, 1999 [Dissertação de Mestrado - Universidade Mackenzie ]

Robertson LJ, Campbell AT, Smith HV. Survival of Cryptosporidium parvum oocysts under various environmental pressures. Appl Environ Microbiol 1992, 58(11): 3494-3500.

Roberton LJ et al. Giardia cysts and Cryptosporidium oocysts at sewage treatment works in Scotland,UK. Water Res 34(8): 2310-2322, 2000.

Rodgers, MR. Flaningan DJ, Jabukowski, W. Identification of algae which interfere with the detection of Giardia cysts and Cryptosporidium oocysts and a method for alleviating this interference. Appl Environ Microbiol 1995, 61(10): 3759-3763. 
Rose JB, Darbin H, Gerba CP. Correlations of the protozoa, Cryptosporidium and Giarda, with water quality variables in a wathershed. Water Sci Technol 1988, 20(12): 271-276.

Rose JB, Dickson LJ, Farrah S, Carnahan RP. Removal of pathogenic and indicator microorganisms by a full-scale water reclamation facility. Water Res 1996, 30(11):2785-2797.

Rose JB. Environmental ecology of Cryptosporidium and public health implications. Ann Rev Public Health 1997, 18: 135-61.

Rose JB, Huffman DE, Gennaccaro A. Risk and control of waterborne cryptosporidiosis. FEMS Microbiol Rev 2001, 26:113-123

Rouquet V, Homer F, Brignon JM, Bonne P, Cavard J. Source and occurrence of Giardia and Cryptosporidium in Paris rivers. Water Sci Technol. 2001, 41(7):79-86.

Sauda FC, Zamarioli LA, Ebner Filho W, Mello LB. Prevalence of Cryptosporidium sp and Isospora belli among AIDS patients attending Santos Reference Center for AIDS, São Paulo, Brazil. J Parasitol 1993, 79(3): 454-456.

Shepherd KM, Wyn-Jones AP. An evaluation of methods for the simultaneous detection of Cryptosporidium oocysts and Giardia cysts from water. Appl Environ Microbiol 1996, 62(4): 1317-1322.

Siegel S. Estatística não-paramétrica (para as ciência do comportamento). Trad. de AA Farias. São Paulo: McGraw Hill; 1975 
Simmons OD, Sobsey MD, Heaney CD, , Schaefer FW III, Francy DS. Concentration and detection of Cryptosporidium oocysts in surface water samples by method 1622 using ultrafiltration and capsule filtration. Appl Environ Microbiol 2001, 67(3): 1123-1127.

Sinclair MI, Fairley CK, Hellard, ME. Protozoa in drinking water: is legislation the best answer? Med J Aust 1998, 169(9):296-297

Skerret HE, Holland HE. The occurrence of Cryptosporidium in environmental waters in the greater Dublin area. Water Res 2000, 15: 3755-3760.

Slifko TR, Friedman D, Rose JB, Jabukowski W. An in vitro method for detecting infectious Cryptosporidium oocysts with cell culture. Appl Environ Microbiol 1997. 63(9): 3669-3675

Smith HV. Detection of parasites in the environment. Parasitology 1998, 117: S113S141.

Smith HV, Rose JB. Waterborne cryptosporidiosis: current status. Parasitology Today 1998, 14(1): 14-22

Smith HV, Hayes CR. The status of UK methods for the detection of Cryptosporidium spp oocysts and Giardia spp cysts in water concentrates. Water Sci Technol 1997, 35(11-12): 369-376

Smith HV, Rose JB. Waterborne cryptosporidiosis: current status. Parasitol Today $1998,14(1): 14-22$.

Solo-Gabriele H. Neumeister S. US outbreaks of cryptosporidiosis. J Am Water Works Assoc 1996, 88(9):76-85. 
Solo-Gabriele HM et al. Occurence of Cryptosporidium oocysts and Giardia cysts in water supplies of San Pedro Sula, Honduras. Rev Panam Salud Publica 1998, $4(6): 398-400$

Stanfield $\mathrm{G}$ et al. An optimised and standardised test to determine the presence of the protozoa Cryptosporidium and Giardia in water. Water Sci Technol 2000 41(7): $103-110$.

States S, Stadterman K, Ammon L, Vogel P, Baldizar J, Wright D, Conley L, Sykora J. Protozoa in river water: sources, occurrence and treatment. J Am Water Works Assoc 1997, 89(9): 74-83.

Stinear T, Matusan A, Hines K, Sandery M. Detection of a single viable Cryptosporidium parvum oocyst in environmental water concentrates by reverse transcriptase PCR. Appl Environ Microbiol 1996,62(9):3385-3390.

Tillett HE, Sellwood J, Lightfoot NF, Boyd P, Eaton S. Correlation between microbial parameters from water samples: expectations and reality. Water Sci Technol 2001, 43(12: 19-22.

Thompson RC, Morgan UM, Mellor KJ, Hopkins RM. Genotyping Giardia and Cryptosporidium. Today's Life Sci 1999, 11(3):80-87.

Thompson RC. Giardiasis as a re-emerging infectious disease and its zoonotic potential. Int J Parasitol 2000, 30:1259-1267.

Thurman R, Faulkner B, Veal D. Cramer G. Meiklejohn M. Water quality in rural Australia. J Appl Microbiol 1998, 84:627-632.

Tomps SR. Estudo epidemiológico da criptosporidiose e sua associação com as condições de saneamento ambiental no distrito municipal de Perus, São Paulo, SP. São Paulo; 1998. [Dissertação de Mestrado - Universidade Mackenzie]. 
United States Environmental Protection Agency (USEPA). Office of Ground Water and Drinking Water 1995. ICR Protozoan Method for Detecting Giardia cysts and Cryptosporidium Oocysts in Water by a Fluorescent Antibody Procedure. EPA/814-95-003. Available from [URL:http:// www.epa.gov/nerlcwww/pvid.pdf]. $[11 / 03 / 00]$.

United States Environmental Protection Agency (USEPA). National Primary Drinking Water Regulations: Monitoring Requirements for Public Drinking Water Supplies; Final Rule. 40 CFR Part 141. May 14, 1996.

United States Environmental Protection Agency (USEPA). National Primary Drinking Water Regulations: Interim Enhanced Surface Water Treatment Rule; Final Rule. 40 CFR Parts 9, 141 and 142. December 16, 1998a.

United States Environmental Protection Agency (USEPA). Office of Water. Washington DC. 1998b. Method 1622: Cryptosporidium in water by filtration/IMS/FA. EPA-821-R-98-010. Available from [URL:http:// www.epa.gov/nerlcwww/1622ap01.pdf]. [20/03/00].

United States Environmental Protection Agency. Office of Water. Washington DC 20460. 1999. Method 1623: Cryptosporidium and Giardia in water by filtration/IMS/FA. EPA-821-R-99-006. Available from [URL:http:// www.epa.gov/nerlcwww/1623ap01.pdf]. [25/03/00].

United States Environmental Protection Agency (USEPA). National Primary Drinking Water Regulations: Long Term 1 Enhanced Surface Water Treatment and Filter Backwash Rule; Proposed Rule. 40 CFR Parts 141 and 142. April 10 2000. 
United States Environmental Protection Agency. Office of Water. Washington DC 20460. 1999. Method 1623: Cryptosporidium and Giardia in water by filtration/IMS/FA. EPA-821-R-01-025. Available from [URL:http:// www.epa.gov/nerlcwww/1623ap01.pdf]. [11/03/02].

Vesey G., Slade JS, Byrne M, Shepherd K, Dennis PJ, Fricker CR. A new method for the concentration of Cryptosporidium oocysts from water. J Appl Bacteriol 1993, 75: 82-86.

Wallis PM, Erlandsen Sl, Isaac-Renton JL, Olson ME, Robertson WJ, van Keulen H. Prevalence of Giardia cysts and Cryptosporidium oocysts and characterization of Giardia spp. Isolated from drinking water in Canada. Appl Environ Microbiol $1996,62(8): 2789-2797$

Weikel CS, Johnston LI, Souza MA, Guerrant RL. Cryptosporidiosis in Northeastern Brazil: association with sporadic diarrhea. J Infect Dis 1985, 151(5):963-965.

World Health Organization. Water, sanitation and health. Guidelines for drinking water quality. Microbiological aspects. Geneva; 1993. Available from <URL:http://www.who.int/water_sanitation_health/GDWQMicrobiological2.htm>.

World Health Organization. World Health Organization Report on Infectious Diseases. Removing obstacles to healthy development. 1999. Available from < URL:http://www. who.int/infectious-disease-report/pages/textonly.html>.

Wuhib $\mathrm{T}$ et al Cryptosporidial and microsporidial infections in human immunodeficiency virus-infected patients in northeastern Brazil. J Infect Dis 1994. $170(8): 494-497$

Young $\mathrm{Pl}$. Komisar SJ. The variability introduced by partial sample analysis to numbers of Cryptosporidium oocysts and Giardia cysts reported under the Information Collection Rule. Water Res 1999, 33(11): 2660-2668 
$\mathrm{Zu}$ SX et al. Seroepidemiologic study of Cryptosporidium infection in children from rural communities of Anhui, China and Fortaleza, Brazil. Am J Trop Med Hyg $1994,51(1): 1-10$.

Zuckerman U, Gold D, Shelef G, Armon R. The presence of Giardia and Cryptosporidium in surface waters and effluents in Israel. Water Sci Technol 1997, 35(11-12): 381-384. 
ANEXO 1

SOLUÇÕES E REAGENTES UTILIZADOS NAS ANÁLISES DE Giardia sp, Cryptosporidium sp $\mathrm{E}$ INDICADORES DE CONTAMINAÇÃO FECAL

1 - Giardia sp e Cryptosporidium sp (Técnica de Concentração por Floculação com Carbonato de Cálcio e Microscopia de Imunofluorescência )

1.1 - Solução de cloreto de cálcio $1 \mathrm{M}$

Cloreto de cálcio $\left(\mathrm{CaCl}_{2} .2 \mathrm{H}_{2} \mathrm{O}\right)$ $14,7 \mathrm{~g}$

Água destilada. $100 \mathrm{~mL}$

1.2 - Solução de bicarbonato de sódio $1 \mathrm{M}$

Bicarbonato de sódio $\left(\mathrm{NaHCO}_{3}\right)$ $8,4 \mathrm{~g}$

Água destilada. $100 \mathrm{~mL}$

1.3 - Solução de ácido sulfâmico $10 \%$

Ácido sulfâmico. $20 \mathrm{~g}$

Água destilada. $200 \mathrm{~mL}$

1.4 - Solução de hidróxido de sódio $1 \mathrm{M}$

Hidróxido de sódio. $4 \mathrm{~g}$

Água destilada. $100 \mathrm{~mL}$ 


\section{5 - Solução de Tween $0,01 \%$}

Tween 80 $0,1 \mathrm{~mL}$

Água destilada. $100 \mathrm{~mL}$

1.6 - Kit de imunofluorescência direta para determinação de cistos de Giardia sp e oocistos de Cryptosporidium sp*

*Merifluor -.Meridian Diagnostics Inc.. Cincinnati. Ohio

\section{2 - Indicadores Bacterianos de Contaminação Fecal}

\section{1 - Água de diluição}

\section{Solução estoque de fostato}

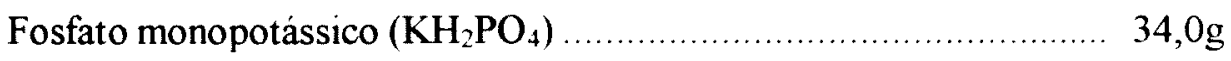

Água destilada .....................................................................

$\mathrm{O}$ fosfato foi dissolvido em $500 \mathrm{~mL}$ de água destilada, o $\mathrm{pH}$ acertado a 7,2 $\pm 0,5$ com $\mathrm{NaOH} 1 \mathrm{~N}$ e o volume completado a $1000 \mathrm{~mL}$ com água destilada.

\section{Solução estoque de cloreto de magnésio}

Cloreto de magnésio hexa-hidratado $\left(\mathrm{MgCl}_{2} .6 \mathrm{H}_{2} \mathrm{O}\right) \ldots \ldots \ldots \ldots \ldots \ldots . \ldots \ldots \ldots$

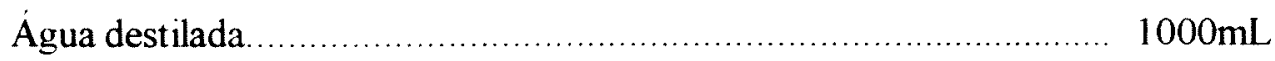

Foram adicionados $1,25 \mathrm{~mL}$ da solução estoque de fosfato e $5,0 \mathrm{~mL}$ da solução de cloreto de magnésio a $1 \mathrm{~L}$ de água destilada. Foram distribuidos $90 \mathrm{~mL}$ em frascos de diluição que foram autoclavados a $121^{\circ} \mathrm{C}$ durante 15 minutos 


\section{2 - Meio de cultura A1- concentração simples}

Lactose.

$5,0 \mathrm{~g}$

Triptona.....

$20,0 \mathrm{~g}$

Cloreto de sódio $(\mathrm{NaCl})$ $5,0 \mathrm{~g}$

Salicina. $0,5 \mathrm{~g}$

Polietileno glicol p-iso-octil-fenil éter** $\overline{1}, 0 \mathrm{~mL}$

Água destilada $1000 \mathrm{~mL}$

$\mathrm{O}$ meio de cultura foi preparado pelas instruções do fabricante, distribuido em volumes de $10 \mathrm{~mL}$, em tubos de ensaio $16 \times 150 \mathrm{~mm}$, de tampa metálica, contendo tubos de fermentação de $5 \mathrm{~mm} \times 40 \mathrm{~mm}$ e autoclavado a $121^{\circ} \mathrm{C}$, durante 15 minutos.

*Devem ser utilizados preferencialmente meios desidratados. quando estes forem disponiveis comercialmente

* Tnton X-100. Rohm \& Haas ou equivalente

\section{3 - Meio de cultura A1- concentração dupla}

Lactose $10,0 \mathrm{~g}$

Triptona $40,0 \mathrm{~g}$

Cloreto de sódio $(\mathrm{NaCl})$ $10,0 \mathrm{~g}$

Salicina $1,0 \mathrm{~g}$

Polietileno glicol p-iso-octil-fenil éter* $2,0 \mathrm{~mL}$

Água destilada $1000 \mathrm{~mL}$

O meio de cultura foi preparado seguindo-se as instruções do fabricante, distribuido em volumes de $10 \mathrm{~mL}$, em tubos de ensaio $18 \times 150 \mathrm{~mm}$, de tampa metálica, contendo tubos de fermentação de $7 \mathrm{~mm} \times 45 \mathrm{~mm}$ e autoclavado a $121^{\circ} \mathrm{C}$, durante 15 minutos. 


\section{4 - Caldo dextrose-azida concentração simples}

Extrato de carne Merck....................................................... 4,5g

Triptona ou polipetona Merck ............................................. 15,0g

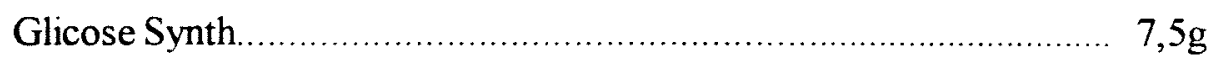

Cloreto de sódio $(\mathrm{NaCl})$ Synth .......................................... 7,5g

Azida de sódio $\left(\mathrm{NaN}_{3}\right)$ Difco .............................................. $0,2 \mathrm{~g}$

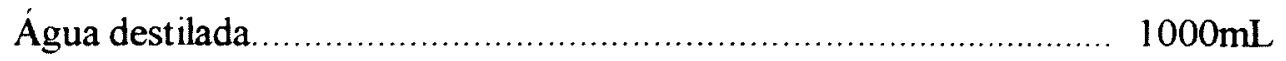

Após a esterilização o $\mathrm{pH}$ deve ser 7,2 $\pm 0,2$

$\mathrm{O}$ meio de cultura foi preparado seguindo-se as instruções do fabricante, distribuído em volumes de $10 \mathrm{~mL}$, em tubos de ensaio $16 \times 150 \mathrm{~mm}$, de tampa metálica e autoclavado a $121^{\circ} \mathrm{C}$, durante 15 minutos.

\section{5 - Caldo dextrose azida concentração dupla}

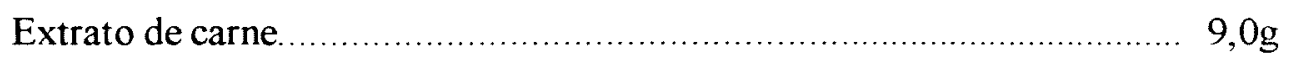

Triptona ou polipetona........................................................ 2,

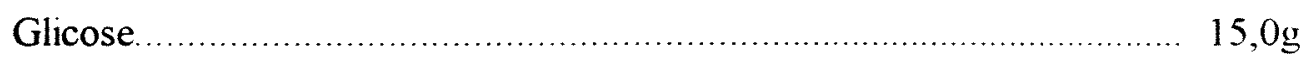

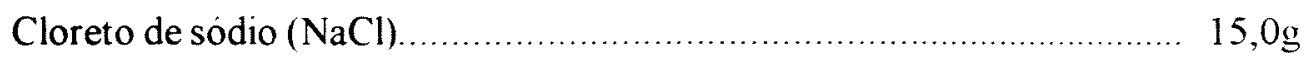

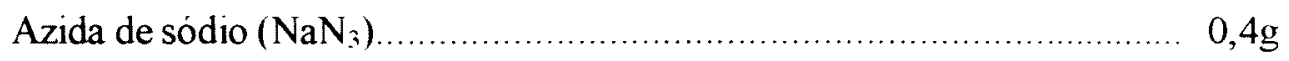

Água destilada................................................................. $1000 \mathrm{~mL}$

Após a esterilização o pH deve ser 7,2 $\pm 0,2$

$\mathrm{O}$ meio de cultura foi preparado seguindo-se as instruções do fabricante, distribuído em volumes de $10 \mathrm{~mL}$, em tubos de ensaio $18 \times 150 \mathrm{~mm}$, de tampa metálica e autoclavado a $121^{\circ} \mathrm{C}$, durante 15 minutos. 


\section{6 - Ágar PSE (ágar seletivo Pfeizer para enterococos)}

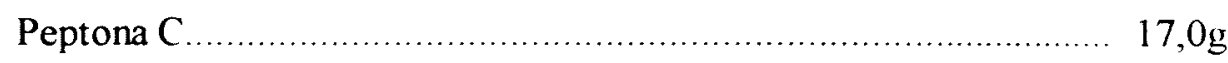

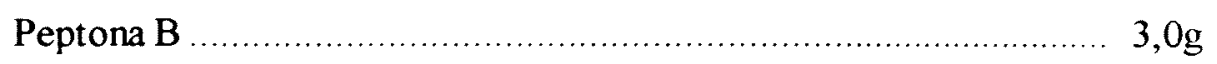

Extrato de levedura ….........................................................

Bile bacteriológica ........................................................... 10,

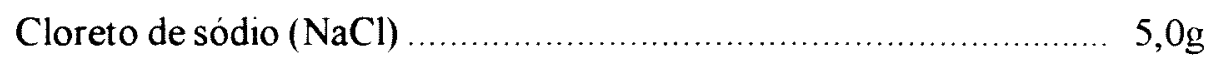

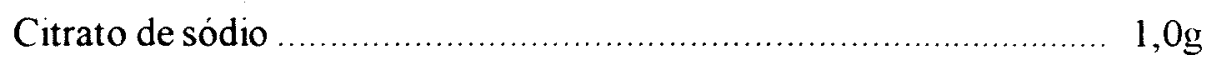

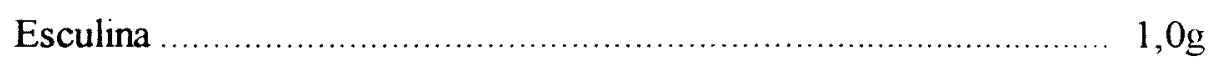

Citrato férrico amoniacal ............................................ $0,5 \mathrm{~g}$

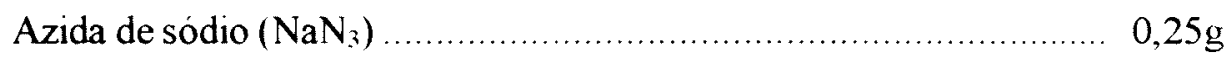

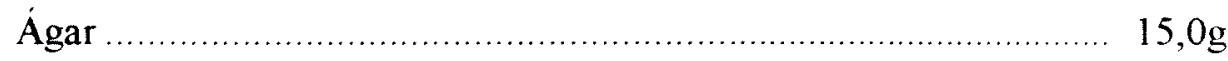

Água destilada .............................................................. $1000 \mathrm{~mL}$

Após a esterilização o pH do meio deve ser $7,1 \pm 0,2$

$\mathrm{O}$ meio foi preparado seguindo-se as instruções do fabricante, esterilizado a $121^{\circ} \mathrm{C}$, durante 15 minutos, e distribuido em volumes de $15 \mathrm{~mL}$ em placas de Petri de $15 \times 100 \mathrm{~mm}$.

\section{7 - Meio DRCM ("Differential Reinforced Clostridium Medium") concentração simples}

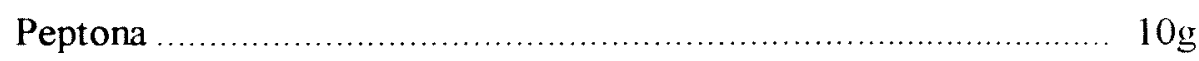

Extrato de carne purificado (em pó) ................................ $10 \mathrm{~g}$

Acetato de sódio hidratado ........................................... $5 \mathrm{~g}$

Extrato de levedura ..................................................... $1,5 \mathrm{~g}$

Amido solúvel ............................................................ $\mid g$

Glicose ...................................................................... $1 \mathrm{~g}$

L-cisteina ......................................................................... $0,5 \mathrm{~g}$

Água destilada................................................................ $1000 \mathrm{~mL}$ 
A peptona, o extrato de carne, o acetato de sódio e o extrato de levedura foram dissolvidos em $800 \mathrm{~mL}$ de água. Dos $200 \mathrm{~mL}$ de água restante, foi preparada uma pasta, com um pouco de água e o amido, fervendo-se o restante e juntando-se à pasta. Essa suspensão foi então adicionada aos $800 \mathrm{~mL}$ com os outros componentes, dissolvendo-se finalmente a glicose e a cisteína. $\mathrm{O} \mathrm{pH}$ foi ajustado a 7,2 com $\mathrm{NaOH}$ $1 \mathrm{~N}$ e o meio foi distribuído em volumes de $10 \mathrm{~mL}$ em tubos de ensaio de $18 \mathrm{X} 180 \mathrm{~mm}$, tamponados com algodão e autoclavados a $121^{\circ} \mathrm{C}$, durante 15 minutos.

\section{8 - Meio DRCM ("Differential Reinforced Clostridium Medium") concentração dupla}

Peptona. $20 \mathrm{~g}$

Extrato de carne purificado (em pó) .................................... 20g

Acetato de sódio hidratado............................................... $10 \mathrm{~g}$

Extrato de levedura ...........................................................

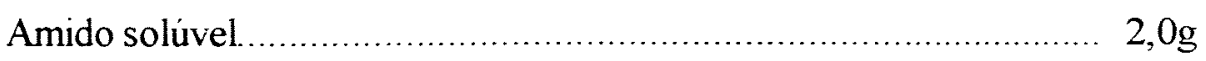

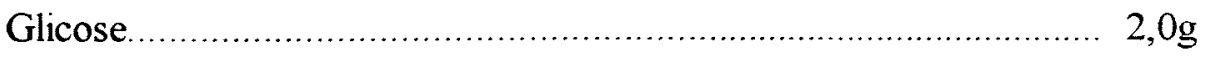

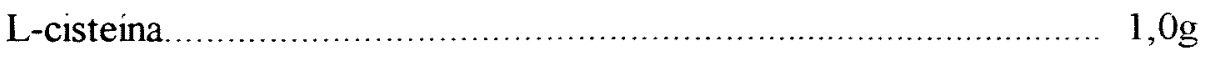

Ȧgua destilada......................................................... $1000 \mathrm{~mL}$

Esse meio foi preparado de forma semelhante ao meio DRCM concentração simples, distribuido em volumes de $10 \mathrm{~mL}$ em tubos $18 \times 180 \mathrm{~mm}$, tamponados com algodão e esterilizados a $121^{\circ} \mathrm{C}$, durante 15 minutos.

\subsection{0 - Solução de sulfito de sódio}

Sulfito de sódio $4 g$

Água destilada

$100 \mathrm{~mL}$

O sulfito de sódio foi dissolvido na água, e a solução resultante esterilizada por filtração através de membrana de $0,22 \mu \mathrm{m}$ e distribuida em volumes de $100 \mathrm{~mL} \mathrm{em}$ frascos com tampa de rosca. 


\subsection{1 - Solução de citrato férrico}

Citrato férrico $7 \mathrm{~g}$

Água destilada $100 \mathrm{~g}$

O citrato férrico foi dissolvido em água, a solução resultante esterilizada por filtração através de membrana de $0,22 \mu \mathrm{m}$ e distribuida em volumes de $100 \mathrm{~mL}$ em frascos com tampa de rosca.

\subsection{2 - Leite tornassolado ("Litmus "milk")}

Leite desnatado $100 \mathrm{~g}$

Tornassol (litmus). $0,75 \mathrm{~g}$

$\mathrm{O}$ meio foi preparado segundo as instruções do fabricante, o pH acertado a 6,8 com solução $1 \mathrm{~N}$ de $\mathrm{NaOH}$, e foram distribuídos volumes de $7 \mathrm{~mL}$ em tubos $12 \mathrm{X} 120 \mathrm{~mm}$ que foram autoulavados a $121^{\circ} \mathrm{C}$, durante 15 minutos. 
ANEXO 2

TABELA - INDICE DE NMP E LIMITES DE CONFIANÇA DE 95\%

\begin{tabular}{|c|c|c|c|c|c|}
\hline \multicolumn{3}{|c|}{$\begin{array}{l}\text { Número de tubos com reação positiva quando } \\
\text { são utilizados, em séries de } 5 \text { tubos, inóculos de: }\end{array}$} & \multirow{2}{*}{$\begin{array}{c}\text { Indice de } \\
\mathrm{NMP} / 100 \mathrm{ml}\end{array}$} & \multicolumn{2}{|c|}{ Limites de confiança de $95 \%$} \\
\hline $10 \mathrm{ml}$ & $1 \mathrm{ml}$ & $0,1 \mathrm{ml}$ & & Inferior & Superior \\
\hline 0 & 0 & 0 & $<2$ & - & - \\
\hline 0 & 0 & 1 & 2 & 1 & 10 \\
\hline 0 & 1 & 0 & 2 & 1 & 10 \\
\hline 0 & 2 & 0 & 4 & 1 & 13 \\
\hline 1 & 0 & 0 & 2 & 1 & 11 \\
\hline 1 & 0 & 1 & 4 & 1 & 15 \\
\hline 1 & 1 & 0 & 4 & 1 & 15 \\
\hline 1 & 1 & 1 & 6 & 2 & 18 \\
\hline 1. & 2 & 0 & 6 & 2 & 18 \\
\hline 2 & 0 & 0 & 4 & 1 & 17 \\
\hline 2 & 0 & 1 & 7 & 2 & 20 \\
\hline 2 & 1 & 0 & 7 & 2 & 21 \\
\hline 2 & 1 & 1 & 9 & 3 & 24 \\
\hline 2 & 2 & 0 & 9 & 3 & 25 \\
\hline 2 & 3 & 0 & 12 & 5 & 29 \\
\hline 3 & 0 & 0 & 8 & 3 & 24 \\
\hline 3 & 0 & 1 & 11 & 4 & 29 \\
\hline 3 & 1 & 0 & 11 & 4 & 29 \\
\hline 3 & 1 & 1 & 14 & 6 & 35 \\
\hline 3 & 2 & 0 & 14 & 6 & 35 \\
\hline 3 & 2 & 1 & 17 & 7 & 40 \\
\hline 4 & 0 & 0 & 13 & 5 & 38 \\
\hline 4 & 0 & 1 & 17 & 7 & 45 \\
\hline 4 & 1 & 0 & 17 & 7 & 46 \\
\hline 4 & 1 & 1 & 21 & 9 & 55 \\
\hline 4 & $i$ & 2 & 26 & 12 & 63 \\
\hline 4 & 2 & 0 & 22 & 9 & 56 \\
\hline 4 & 2 & 1 & 26 & 12 & 65 \\
\hline 4 & 3 & 0 & 27 & 12 & 67 \\
\hline 4 & 3 & 1 & 33 & 15 & 77 \\
\hline 4 & 4 & 0 & 34 & 16 & 80 \\
\hline 5 & 0 & 0 & 23 & 9 & 86 \\
\hline 5 & 0 & 1 & 30 & 10 & 110 \\
\hline 5 & 0 & 2 & 40 & 20 & 140 \\
\hline 5 & 1 & 0 & 30 & 10 & 120 \\
\hline 5 & 1 & 1 & 50 & 20 & 150 \\
\hline 5 & 1 & 2 & 60 & 30 & 180 \\
\hline 5 & 2 & 0 & 50 & 20 & 170 \\
\hline 5 & 2 & 1 & 70 & 30 & 210 \\
\hline 5 & 2 & 2 & 90 & 40 & 250 \\
\hline 5 & 3 & 0 & 80 & 30 & 250 \\
\hline 5 & 3 & 1 & 110 & 40 & 300 \\
\hline 5 & 3 & 2 & 140 & 60 & 360 \\
\hline 5 & 3 & 3 & 170 & 80 & 410 \\
\hline 5 & 4 & 0 & 130 & 50 & 390 \\
\hline 5 & 4 & 1 & 170 & 70 & 480 \\
\hline 5 & 4 & 2 & 220 & 100 & 580 \\
\hline 5 & 4 & 3 & 280 & 120 & 690 \\
\hline 5 & 4 & 4 & 350 & 160 & 820 \\
\hline 5 & 5 & 0 & 240 & 100 & 940 \\
\hline 5 & 5 & 1 & 300 & 100 & 1.300 \\
\hline 5 & 5 & 2 & 500 & 200 & 2.000 \\
\hline 5 & 5 & 3 & 900 & 300 & 2.900 \\
\hline 5 & 5 & 4 & 1.600 & 600 & 5.300 \\
\hline 5 & 5 & 5 & $\geq 1.600$ & - & - \\
\hline
\end{tabular}

FONTE: "Standard Methods for the Examination of Water and Wastewater" 1998 